\title{
A SOCIEDADE EM CONTA DE PARTICIPAÇÃO NO DIREITO BRASILEIRO
}

\author{
DiSSERTAÇÃO DE MESTRAdO
}

Orientador: Professor Livre Docente Eduardo Secchi Munhoz

Candidata: Ana Carolina Barbuio Affonso (n. ${ }^{\circ}$ USP 4948234)

FaCUldade de Direito da UniVersidade de São Paulo

São Paulo, janeiro de 2014. 
SUMÁRIO

CAPÍTULO I INTRODUÇÃO 7

I.1 Apresentação e relevância do tema................................................................. 7

I.2 Limitações do tema e principais questões que serão analisadas........................ 11

CAPÍTULO II ORIGEM E EVOLUÇÃO HISTÓRICA …................................... 15

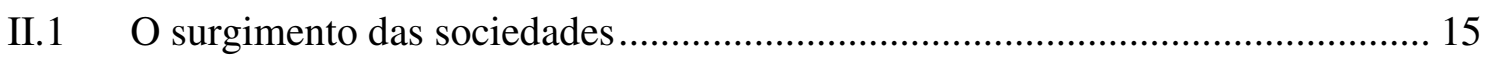

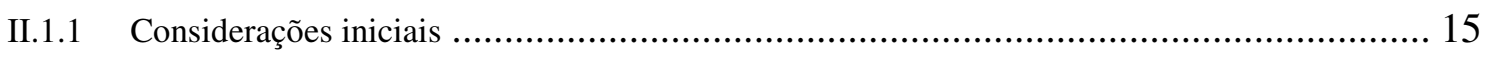

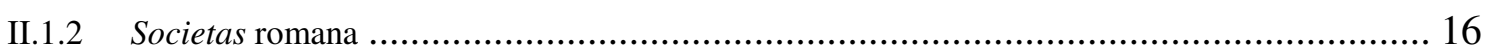

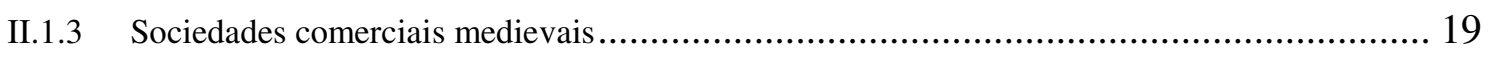

II.2 Origem da sociedade em conta de participação: contrato de comenda .............. 23

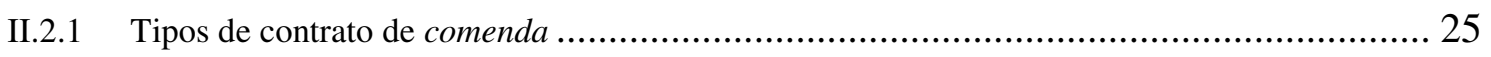

II.2.2 Desenvolvimento e publicidade dos contratos de comenda .......................................... 29

II.2.3 Evolução dos contratos de commenda para a forma de sociedade e diferentes posicionamentos sobre a influência dos contratos de commenda para o surgimento das sociedades em conta de

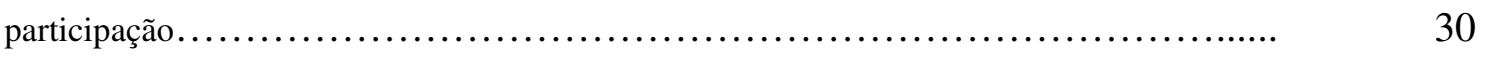

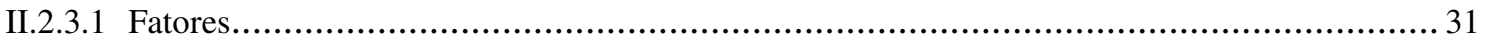

II.2.3.2 Origem das sociedades em conta de participação: diferentes posicionamentos ..........................32

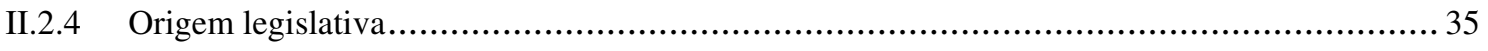

II.2.5 A codificação da sociedade em conta de participação no direito brasileiro ...............................35

CAPÍTULO III NATUREZA JURÍDICA, REQUISITOS DE VALIDADE, CONCEITO E PRINCIPAIS CARACTERÍSTICAS DAS SOCIEDADES EM

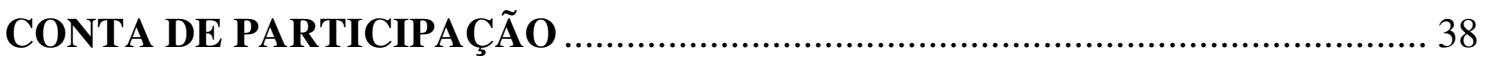

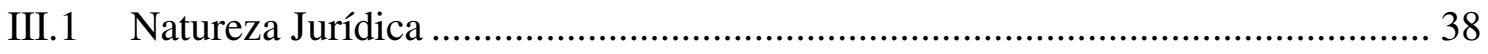

III.2 Requisitos de validade do instrumento de constituição da sociedade em conta de participação 45 
III.3 Conceito da Sociedade em Conta de Participação............................................... 49

III.4 Principais características da sociedade em conta de participação ...................... 52

III.4.1 Impossibilidade de assumir obrigações e ser titular de direitos ......................................... 53

III.4.2 Impossibilidade de ser parte em processo administrativo e judicial ................................. 53

III.4.3 Ausência de patrimônio próprio ............................................................................ 54

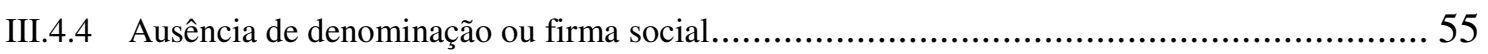

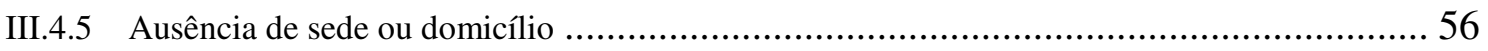

III.4.6 Prazo de duração da Sociedade em Conta de Participação ............................................... 56

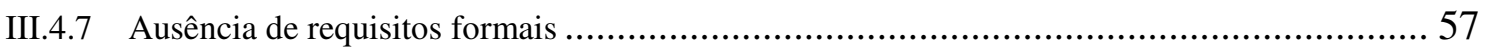

III.4.8 Eventual possibilidade de emissão de títulos negociáveis .............................................58

III.5 Aspectos fiscais da sociedade em conta de participação ................................. 61

\section{CAPÍTULO IV O PATRIMÔNIO DA SOCIEDADE EM CONTA DE

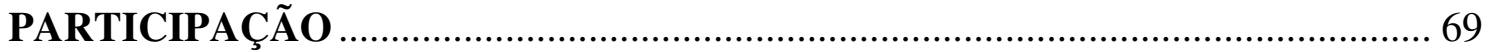

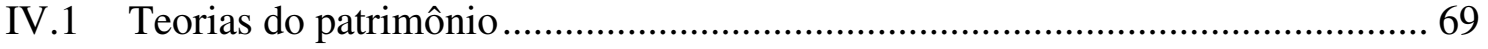

IV.2 Classificação jurídica do patrimônio no direito brasileiro.................................. 73

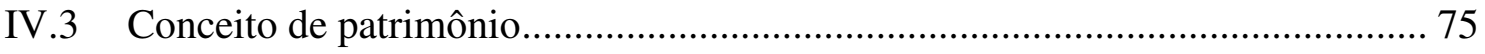

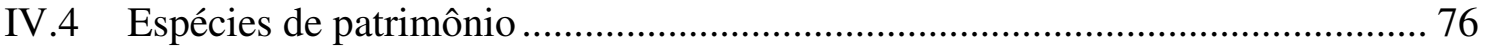

IV.5. Definição dos conceitos de patrimônio de afetação, patrimônio separado, patrimônio especial e patrimônio autônomo ……….......................................................... 78

IV.6 Conceito, estrutura e natureza do patrimônio separado ou especial ................... 80

IV.7 Exemplos de afetação patrimonial no direito brasileiro ................................. 85

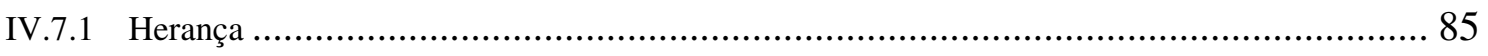

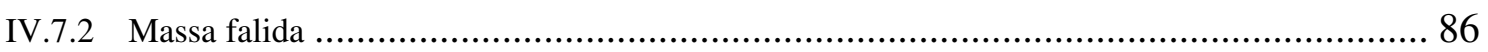

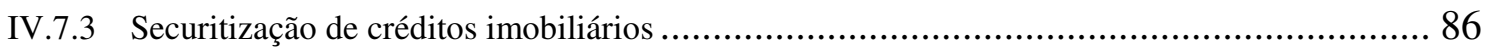

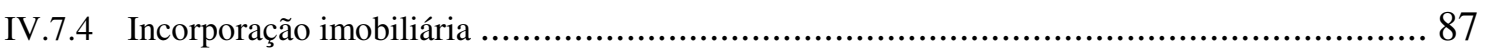

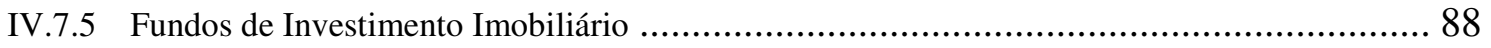

IV.7.6 Câmara de Compensação e Liquidação do Sistema Brasileiro de Pagamentos - SPB, disciplinado pela Lei n. ${ }^{\circ} 10.214$, de 27 de março de 2001 89 


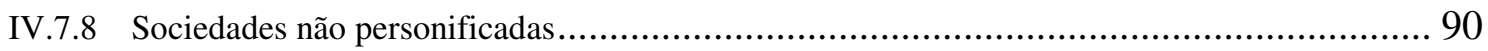

IV.8 Patrimônio especial da sociedade em conta de participação ............................................ 91

IV.8.1 Propriedade dos fundos sociais que compõe o patrimônio especial ................................... 97

CAPÍtUlO V SÓCIOS: ADMISSÃO, SAÍdA, PARTICIPAÇÃO NOS

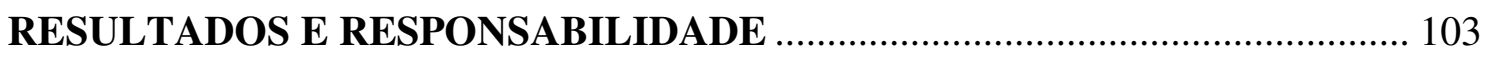

V.1 Sócios: espécies, admissão, saída, participação nos resultados ........................ 103

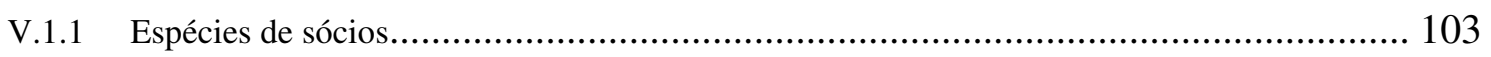

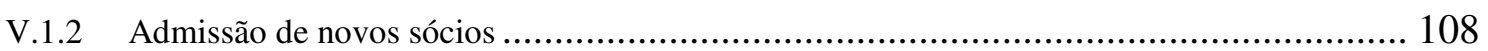

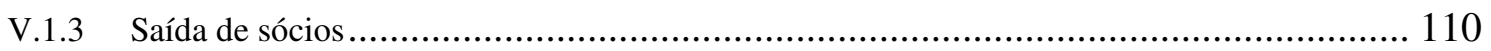

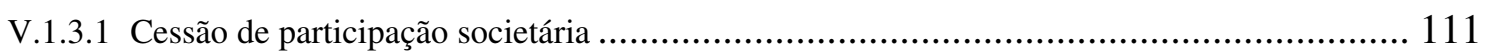

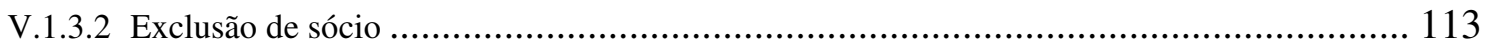

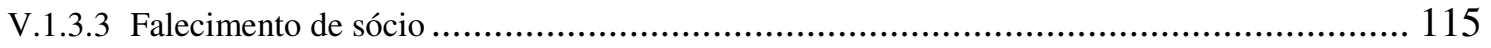

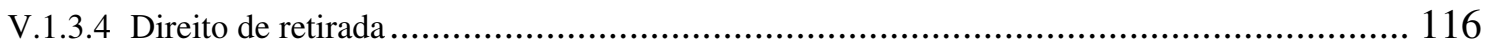

V.1.3.5 Falência de sócio ostensivo e falência de sócio participante.......................................... 117

V.2 Responsabilidade dos sócios da sociedade em conta de participação ............... 120

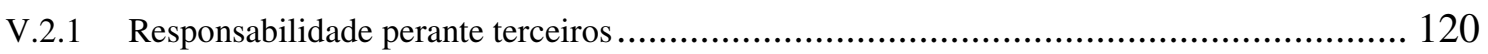

V.2.2 Regras de responsabilidade dos sócios aplicáveis nas relações internas da sociedade em conta de participação.

V.3 Participação dos sócios nos resultados ........................................................ 124

V.4 Administração da sociedade em conta de participação ................................... 126

CAPÍTULO VI TÉRMINO DA SOCIEDADE ............................................. 130

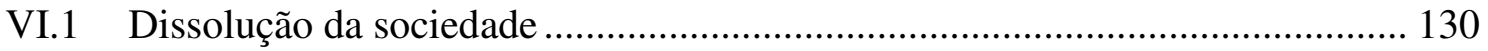

VI.2 Liquidação da sociedade........................................................................ 133

CAPÍTULO VII FUNÇÃO E PRÁTICA DAS SOCIEDADES EM CONTA DE

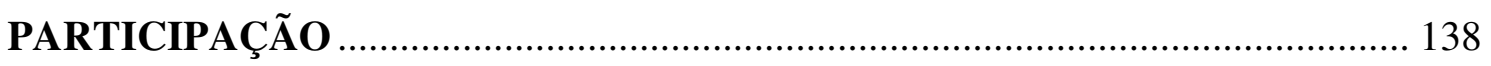

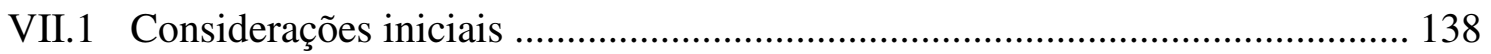


VII.2 Estruturação jurídica de negócios imobiliários via utilização de sociedade em conta de participação

VII.2.1Empreendimentos imobiliários

VII.2.2Utilização de sociedades em conta de participação como estrutura jurídica apta a formalizar pools hoteleiros e flats

VII.3 A utilização da sociedade em conta de participação no âmbito de projetos florestais

VII.4 A utilização da sociedade em conta de participação como espécie de joint venture

VII.5 A sociedade em conta de participação na jurisprudência brasileira

VII.5.1 Objetivos

VII.5.2 Metodologia para a formação do banco de dados

VII.5.3 Resultados

VII.5.3.1TJSP e TJRJ

VII.5.3.2 STJ

VII.5.3.3 STF

VII.5.3.4Utilização da sociedade em conta de participação como forma de evitar a aplicação de normas específicas e mais rígidas

VII.5.3.4.1Utilização das SCPs para evitar a aplicação do Código de Defesa do Consumidor 171

VII.5.3.4.2 Utilização das SCPs para evitar a aplicação da Lei n. ${ }^{\circ}$ 11.795/2008, que dispõe sobre o sistema de consórcio

VII.5.3.4.3 Utilização das SCPs para evitar a aplicação de regras próprias aplicáveis a atividades reguladas 175

VII.6 A utilização das sociedades em conta de participação como forma de instrumentalizar contratos de investimento coletivo sem a observância das regras referentes à emissão, distribuição, negociação e intermediação de valores mobiliários.

VII.6.1Origem e histórico do conceito de valores mobiliários e de contrato de investimento coletivo 
VII.6.1.1 Origem e histórico do conceito de valores mobiliários e de contrato de

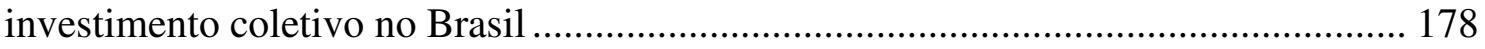

VII.6.1.2 Origem e histórico do conceito de security nos Estados Unidos da América.............................180

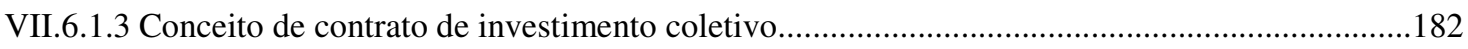

VII.6.1.4A caracterização dos contratos de investimento coletivo como valores mobiliários 183

VII.6.1.5A utilização da sociedade em conta de participação para estruturar contratos de investimento coletivo 184

CAPÍTULO VIII CONCLUSÕES 192 196 


\title{
CAPÍTULO I INTRODUÇÃO
}

\section{I.1 Apresentação e relevância do tema}

Segundo o eminente jurista e historiador português HESPANHA ${ }^{1}$

\begin{abstract}
a estrutura dos institutos jurídicos não resiste ao tempo ou aos diferentes contextos culturais, justamente por servir a distintas funções. Desta forma, ainda que externamente as categorias se assemelhem e possam ter, inclusive, o mesmo nome como propriedade, família, contrato - certo é que guardam diferenças substanciais profundas, a desmascarar o pretenso caráter de neutralidade e de naturalidade de direito. $\mathrm{O}$ direito constitui fenômeno eminentemente histórico-cultural.
\end{abstract}

Com base nesta citação é que o tema desta dissertação deve ser apresentado. A sociedade em conta de participação é um instituto jurídico de origem remota e ainda muito utilizado nas épocas hodiernas.

Diante do entendimento de que a estrutura dos institutos jurídicos não resiste ao tempo por servir a distintas funções é que este trabalho pretende levantar e analisar a evolução das características e funções das sociedades em conta de participação para o fim de avaliar a evolução deste instituto e averiguar se as funções que as sociedades em conta de participação exercem nos dias atuais são semelhantes às funções que exerciam em sua origem. Ademais, esta dissertação pretende avaliar se o instituto hodierno está adequado e ainda é conveniente à economia e ao contexto histórico-cultural brasileiro.

Assim, esta dissertação tem por objetivo desenvolver determinadas questões a respeito do tema “A Sociedade em Conta de Participação no Direito Brasileiro”.

A sociedade em conta de participação possui origem legislativa no Código Espanhol datado de 1829 e no Código Português datado de 1833. No entanto, na prática, a sociedade em conta de participação nasceu na Idade Média, na Itália, em decorrência da proibição da usura pela Igreja Católica e do cenário medieval, que dificultava o

\footnotetext{
${ }^{1}$ HeSPANHA, António Manuel Botelho. Panorama histórico da cultura jurídica europeia. Mem Martins, Portugal: Publicações Europa-América, 1998, p. 101.
} 
exercício do comércio pelos nobres. Há, ainda, juristas que recuam a sua existência até mesmo a período muito mais remoto.

No Brasil, a Lei n. ${ }^{\circ} 556$, de 25 de junho de 1850 ("Código Comercial”) foi o diploma legal precursor da positivação da sociedade em conta de participação.

O artigo 325 do Código Comercial disciplinava a sociedade em conta de participação da seguinte forma: "Quando duas ou mais pessoas, sendo ao menos uma comerciante, se reúnem, sem firma social, para lucro comum, em uma ou mais operações de comércio determinadas, trabalhando um, alguns ou todos, em seu nome individual para o fim social, a associação toma o nome de sociedade em conta de participação, acidental, momentânea ou anônima; esta sociedade não está sujeita às formalidades prescritas para a formação das outras sociedades e pode provar-se por todo o gênero de provas admitidas nos contratos comerciais.". 2

A Lei n. ${ }^{\circ}$ 10.406, de 10 de janeiro de 2002 (“Código Civil de 2002”) alterou de forma significativa a disciplina jurídica da sociedade em conta de participação.

O Código Civil de 2002, ao revogar o artigo 325 do Código Comercial, não define o conceito de sociedade em conta de participação, mas prevê, em seu artigo 991, que "Na sociedade em conta de participação, a atividade constitutiva do objeto social é exercida unicamente pelo sócio ostensivo, em seu nome individual e sob sua própria e exclusiva responsabilidade, participando os demais dos resultados correspondentes.". 3

Por sua vez, o parágrafo único do artigo 991 do Código Civil de 2002 dispõe que "Obriga-se perante terceiros tão-somente o sócio ostensivo; e, exclusivamente perante este, o sócio participante, nos termos do contrato social.". 4

Diante do exposto, pode-se afirmar que a estrutura da sociedade em conta de participação é formada por dois tipos sócios, o sócio ostensivo e o sócio participante. A atividade da sociedade é desenvolvida apenas pelo sócio ostensivo, em seu nome e sob

\footnotetext{
${ }^{2}$ Disponível em: <www.planalto.gov.br>. Acesso em: 25.02.2012.

${ }^{3}$ Disponível em: <www.planalto.gov.br>. Acesso em: 25.02.2012.

${ }^{4}$ Disponível em: <www.planalto.gov.br>. Acesso em: 25.02.2012.
} 
sua exclusiva responsabilidade. Os sócios participantes podem contribuir para a formação do fundo social e participam dos resultados correspondentes.

A redação do artigo 991 do Código Civil de 2002 e a inserção da disciplina da sociedade em conta de participação no capítulo próprio das "sociedades não personificadas" corroboram três importantes características desse tipo societário: a sua caracterização como "sociedade" "regular" "não personificada".

A sociedade em conta de participação é uma sociedade "ad intra", visto que, nos termos do artigo 993 do Código Civil de 2002, produz efeito somente entre os sócios e, portanto, não aparece juridicamente aos olhos do público 5 .

As relações jurídicas com terceiros são formalizadas por meio da figura do sócio ostensivo, que se obriga pessoalmente, em seu próprio nome, mesmo que o terceiro contratante tenha pleno conhecimento da existência da sociedade.

O sócio ostensivo atuará perante terceiros e consequentemente responsabilizará os fundos sociais. Nos termos do artigo 994, parágrafo único do Código Civil de 2002, o fundo social constitui patrimônio especial, que somente produz efeitos em relação aos sócios.

A ausência de personalidade jurídica e, por consequência, a ausência de capacidade jurídica e autonomia patrimonial ensejam outras importantes características da sociedade em conta de participação, quais sejam, a inexistência de denominação social e domicílio e a ausência de legitimidade processual.

A sociedade em conta de participação é constituída por simples consenso dos sócios, desde que respeitados os requisitos gerais necessários para a formação de contratos e os requisitos especiais para a formação de contratos plurilaterais. A constituição da sociedade em conta de participação independe, portanto, de

\footnotetext{
${ }^{5}$ Para fins tributários, a sociedade em conta de participação é equiparada à pessoa jurídica, conforme previsto no artigo 148 do Decreto n. ${ }^{\circ} 3.000$, de 26 de março de 1999 - Regulamento do Imposto de Renda.
} 
formalidades e admite provas por todos os meios de direito, conforme preconiza o artigo 992 do Código Civil de 2002.

Uma vez expostas as principais características da sociedade que será objeto deste trabalho, convém delinear a relevância do tema.

A escolha do objeto desta dissertação justifica-se, de um lado, diante da grande utilidade prática da sociedade em conta de participação nos dias atuais e, de outro lado, pela inexistência de estudos em número expressivo sobre a matéria, especialmente após o advento do Código Civil de 2002.

Assim, a elaboração de dissertação a respeito das sociedades em conta de participação no direito brasileiro apresenta importância pela necessidade de compilação e organização do material até o momento produzido sobre o assunto, seja no direito brasileiro, seja no direito estrangeiro.

A contribuição da dissertação, portanto, não estaria na inovação das conclusões a respeito do tema objeto desta dissertação, mas sim na aplicação das técnicas científicas que possibilitem a produção de um trabalho útil para a comunidade acadêmica. Pretende-se aplicar técnicas de pesquisa para o fim de se analisar de forma pormenorizada assuntos que compõem as principais discussões jurídicas a respeito do tema.

Nesse contexto, um dos principais capítulos desta dissertação abordará os aspectos jurídicos relacionados ao patrimônio especial das sociedades em conta de participação. Entendemos que esse estudo é de grande valia diante do inexpressivo número de materiais acadêmicos a esse respeito no direito brasileiro. Além disso, a correta conceituação e entendimento deste tema são essenciais para a averiguação das regras de responsabilidade aplicáveis a esse tipo de sociedade.

Ademais, a escolha do tema também se justifica pelo levantamento de informações atualizadas a respeito da forma de utilização das sociedades em conta de participação. 
A simplicidade da sociedade em conta de participação, cuja constituição independe de registros e formalizações, bem como a possibilidade de um ou mais sócios permanecerem ocultos, sem assumir obrigações perante terceiros, faz com que este tipo de sociedade caracterize-se como um instrumento jurídico capaz de viabilizar a participação de investidores, seja de pequeno ou grande porte.

Atualmente, sociedades dessa natureza são muito utilizadas para formalizar empreendimentos ambientais e imobiliários, inclusive para a exploração de flats. Esta dissertação pretende pontuar as características das sociedades em conta de participação que as tornam atrativas para o setor imobiliário e também para formalizar projetos de reflorestamento florestal.

Um dos aspectos relevantes deste estudo consiste em demonstrar que a sociedade em conta de participação é um tipo societário cuja utilização pode beneficiar a concretização de determinados negócios e contribuir para o aprimoramento da economia brasileira. A demanda pela utilização desse tipo societário certamente exige um estudo profundo de suas principais vertentes, especialmente as vigentes após o advento do Código Civil de 2002. Essa dissertação pretende cobrir esta demanda.

Por outro lado, este trabalho não deixará de abordar e analisar o fato do recente desvirtuamento na constituição de determinadas sociedades em conta de participação, o que pode implicar prejuízos para os consumidores, para o mercado e para a economia em geral.

\section{I.2 Limitações do tema e principais questões que serão analisadas.}

Conforme exposto acima, as sociedades em conta de participação possuem origem remota, que recua à Idade Média. A posição doutrinária dominante no que se refere às causas de surgimento da conta de participação defende que a estrutura que lhe é própria, e que será analisada de forma pormenorizada na dissertação de mestrado, propiciou o exercício do comércio pelos nobres em um cenário medieval em que predominava a proibição da usura pela Igreja Católica. 
Apesar da origem remota, a estrutura da sociedade em conta de participação é muito utilizada nos dias atuais. Percebe-se que a estrutura das sociedades em conta de participação se adequou às realidades de diversas épocas e sobreviveu com vigor para atender a demandas e necessidades diversas que surgiram com o decorrer do tempo ${ }^{6}$.

Esta dissertação de mestrado procurará demonstrar as formas de utilização das sociedades em conta de participação hodiernas e, inclusive, analisar determinadas formas de desvirtuamento de suas funções, o que faz com que, não obstante a sua tipicidade societária e a sua grande utilidade prática, em determinados casos, este tipo societário seja enquadrado como algo escuso e propicio ao desenvolvimento de atos ilícitos.

Ademais, esta dissertação de mestrado procurará elencar e analisar as características estruturais das sociedades em conta de participação.

Para tanto, pretende-se apreender a natureza jurídica deste tipo societário. À primeira vista, este tema pode parecer superado, já que o Código Civil de 2002 enquadrou a sociedade em conta de participação no capítulo próprio das sociedades não personificadas.

Além disso, a posição doutrinária dominante defende há tempos que as sociedades em conta de participação caracterizam-se como verdadeira sociedade. No entanto, o que à primeira vista pode parecer superado, na prática merece atenta análise e conjunção de argumentos. Isso porque o Projeto de Lei n. ${ }^{\circ}$ 1572, de 2011, que pretende instituir o Código Comercial Brasileiro, enquadra as sociedades em conta de participação como "contrato de investimento". Portanto, esta dissertação de mestrado

\footnotetext{
${ }^{6}$ A esse respeito, vide excerto elaborado pela Professora Rachel Sztajn "Os tipos resultam de determinados comportamentos sociais geralmente observados em determinada coletividade e, subsequentemente, na medida em que se alarga sua aplicação a outras coletividades, se espraia sobre outras, podem converter-se em normas socialmente aceitas e, finalmente, em normas jurídicas que passarão a reger um certo comportamento social, dito então legalmente típico. (...) Se o tipo societário permaneceu, sobrevivendo a todas as vicissitudes dos embates da vida econômica e das codificações, sem dúvida isso ocorreu por preencherem funções, corresponderem a diferentes necessidades." (SZTAJN, Rachel. Contrato de sociedade e formas societárias. São Paulo: Saraiva, 1989, p. 19-21).
} 
pretende reunir argumentos e corroborar a posição doutrinária dominante no sentido de que as sociedades em conta de participação são verdadeiras sociedades.

Da ausência de personalidade jurídica e, por consequência, da ausência de autonomia patrimonial, decorre um tema que se pretende analisar de forma detalhada e exaustiva, qual seja, a titularidade e os demais aspectos jurídicos relacionados ao fundo social, classificado como patrimônio especial pelo artigo 994 do Código Civil de 2002.

Assim, dentre as características estruturais, será abordado de forma pormenorizada o tema do patrimônio das sociedades em conta de participação. Este tema possui grande relevância, já que foi pouco estudado no Brasil e influencia sobremaneira o regime de responsabilidade dos sócios.

O trabalho abordará, ainda, determinadas questões polêmicas a respeito da sociedade em conta de participação, dentre as quais se destacam: as regras para admissão de novos sócios, a possibilidade de o sócio ostensivo emitir títulos negociáveis, a duração desse tipo societário, os aspectos fiscais envolvidos na escrituração dos fundos sociais e as consequências do eventual registro e publicidade dos documentos constitutivos da sociedade.

O estudo analisará de forma detida os aspectos jurídicos relacionados à administração da sociedade em conta de participação e os poderes, deveres e direitos do sócio ostensivo e do sócio participante, o que inclui a análise do poder de fiscalização inerente à condição de sócio participante, conforme previsto no artigo 993, parágrafo único do Código Civil de 2002.

Por fim, pretende-se estudar os aspectos jurídicos relacionados à dissolução e liquidação da sociedade em conta de participação, bem como às hipóteses de pedido de recuperação judicial/extrajudicial ou decretação de falência do sócio ostensivo e/ou do sócio participante.

Para os fins de análise crítica a respeito dos dispositivos legais que regem este tipo societário no direito brasileiro pretende-se analisar as disposições da legislação estrangeira a respeito do tema. 
Assim, a dissertação de mestrado demonstrará o posicionamento das legislações estrangeiras, especialmente das que inspiraram o legislador nacional, pontuando as particularidades do desenvolvimento da sociedade em conta de participação no Brasil, se comparado com os demais países. Com este contorno, será possível traçar paralelos entre a doutrina pátria e a estrangeira, sempre em busca da posição mais adequada à realidade societária brasileira.

A respeito do direito estrangeiro, convém destacar que este estudo não menciona não priorizou o levantamento de legislação, doutrina e jurisprudência norteamericana pelo fato de inexistir entidade semelhante à sociedade em conta de participação em sua legislação e prática ${ }^{7}$.

\footnotetext{
${ }^{7}$ A esse respeito, Luiz Olavo Baptista e Pascal Durand-Barthez lecionaram que quando da independência das 13 colônias norte-americanas, notou-se uma ascendência considerável do direito holandês na América do Norte, bem como, e principalmente, do direito francês. No que toca ao direito societário, essa influência foi sentida, sobretudo, à medida que o comércio com a França incrementou-se. Nesse estágio das coisas, surgiram por lá tipos societários como o da sociedade em comandita e em conta de participação. Contudo, a partir da imposição do regime da Common Law, esses tipos societários foram praticamente banidos da prática americana, pelo menos da forma como se apresentavam suas estruturas orgânicas, o que reforçou, não muito tempo depois, com a evolução das limited partnerships. (BAPTISTA, Luiz Olavo e DURAND-BARTHEZ, Pascal. Les Associations d'Entreprises (joint ventures) dans le Commerce Internacional. Paris: FEC, 1991, p. 7).
} 


\section{CAPÍTULO II ORIGEM E EVOLUÇÃO HISTÓRICA}

\section{II.1 O surgimento das sociedades}

\section{II.1.1 Considerações iniciais}

As causas do surgimento das sociedades podem ser associadas às características humanas do coletivismo e do espírito associativo. Isso porque o domínio das forças da natureza, bem como o seu aproveitamento exigiram, diversas vezes, a necessidade de associação para obter benefícios individuais ou coletivos. ${ }^{8}$

As associações para exploração de terras, por exemplo, não se resumiram a agrupamentos familiares. Outras organizações se formaram, com vistas a, dentre outros diversos objetivos, desbravar solos e coletar produtos naturais decorrentes de plantios.

Assim, desde os primórdios a terra foi explorada como capital comum, em regime de partilha de resultados obtidos por efeito do trabalho coletivo. No entanto, esse fato não impediu o surto do individualismo, que culminou na superioridade dos mais fortes e produtivos.

Com isso, os mais fortes e produtivos recebiam mais resultados decorrentes das partilhas e conseguiam conservar o excedente para futuras trocas das sobras com vizinhos.

O surgimento das trocas acarretou o desbravamento de terras mais longínquas, bem como o aparecimento da moeda. Além disso, a exploração em comum de propriedades privadas e coletivas ensejou a criação de normas administrativas,

\footnotetext{
${ }^{8}$ Há, inclusive, relatos sobre a prática de atividade mercantil de povos primitivos do norte da Ásia e da África, já que alguns indivíduos confiavam peles de rena a um viajante, que as negociava em troca de outros bens. No regresso, esses bens adquiridos na jornada eram repartidos entre o investidor e o tratante, o que dava forma a uma típica sociedade na qual determinados indivíduos ingressam com capital e determinados outros indivíduos ingressam com trabalho. (REHME, Paul. Historia universal del derecho mercantil. Madrid: Revista de Derecho Privado, 1941. p. 22).
} 
ditadas pelas necessidades coletivas e individuais, aceitas pela totalidade dos interessados e aplicadas de acordo com as diretrizes dos chefes. ${ }^{9}$

\section{II.1.2 Societas romana}

No contexto da análise do desenvolvimento das sociedades, convém mencionar o surgimento da societas romana. ${ }^{10}$

Os romanos foram povos agricultores, que exploravam as terras por meio de comunhão entre os membros da família. Assim, o agrupamento de parentes e amigos, subordinada à chefia do pater familias, ensejou o consortium entre eles. O consortium possibilitava o prosseguimento da vida familiar após o falecimento de seu chefe, ${ }^{11}$ já que este instituto permitia a indivisibilidade dos bens familiares e o prosseguimento da gestão dos bens mesmo após o falecimento do pater familias.

No entanto, com o advento da Lei das XII Tábuas, os herdeiros poderiam, via actio erciscundae, requerer a partilha judicial da herança, de forma que cada um receberia a sua parcela da herança, desaparecendo o interesse familiar intrínseco à herança indivisa. $\mathrm{O}$ referido fato ensejou a necessidade dos herdeiros associarem-se de forma voluntária com vistas a explorar as propriedades herdadas e obter maiores ganhos.

Esta é a origem da societas romana, caracterizada como a comunhão contratual do patrimônio, mediante fixação de obrigações recíprocas, para o fim de partilha de lucros e perdas. ${ }^{12}$

\footnotetext{
${ }^{9}$ Conforme FERREIRA, Waldemar. Tratado de sociedades mercantis. v. 1. São Paulo: Livraria Freitas Bastos S/A, 1952, p. 105-107.

${ }^{10}$ É importante mencionar que antes mesmo do direito romano, as sociedades já podiam ser identificadas no direito grego e até mesmo na antiguidade mais remota. A esse respeito, vide Pontes de Miranda: "No direito babilônico haviam as sociedades. (...) $\mathrm{Na}$ Grécia, as sociedades pululavam, com os fins mais diversos (religiosos, políticos, industriais e comerciais, artísticos, esportivos e de diversões)." (PONTES DE MIRANDA, Francisco Cavalcanti. Tratado de Direito Privado. 3. ed. tomo XLIX. São Paulo: RT, 1984. p. 5).

${ }^{11}$ Conforme FERREIRA, Waldemar. Op. cit., p. 112.

${ }^{12}$ Idem, ibidem.

A menção ao fato de que a societas teve origem no consortium baseia-se na teoria original de Franz Wieacker (WIEACKER, Franz. Hausgenossenschaft und Erwerbgesellchaft, Untersuchungen zur Geschichte de Roemischen Gesellschaftsrechts. Societas. Weimar,1936). No entanto, a origem da
} 
A societas foi o principal instrumento de organização do fenômeno empresarial na Roma antiga. ${ }^{13}$

A societas era um "tipo universal" no qual diferentes formas de associação subsistiam. No entanto, ainda que todas as modalidades societárias tivessem origem comum, não tardaram a se desenvolver formas especiais de sociedades, provocadas pelas diferentes necessidades econômicas. ${ }^{14}$

societas foi objeto de diversos estudos e de controvérsias entre autores. Houve um embate entre dois respeitados autores: Franz Wieacker e Arangio-Ruiz (ARANGIO-RUIZ, Vicenzo. La società in diritto romano. Napoli: Casa Editrice Dott. Eugenio Jovene, 1950). Foi travado um embate entre os dois autores, pois as teses defendidas por Wieacker, em 1936, foram parcialmente rebatidas por Arangio-Ruiz, em 1950; o que fez com que Wieacker se pronunciasse novamente em 1952 de forma a alterar parcialmente seu posicionamento. Para Arangio-Ruiz, a história da societas não apresenta uma evolução linear, resumível tão somente ao consortium. Deve-se considerar o inter-relacionamento de fontes antigas do próprio direito romano com a evolução crescente das exigências do comércio internacional e da evolução do ius gentium. A este respeito, vide MOREIRA ALVES, José Carlos. Direito romano. 14. ed. Rio de Janeiro: Forense, 2007.

${ }^{13}$ Conforme WARDE JÚNIOR, Walfrido Jorge. Responsabilidade dos sócios: a crise da limitação da responsabilidade e a teoria da desconsideração da personalidade jurídica. Belo Horizonte: Del Rey, 2007. Ainda, conforme preconiza Matteo Marrone, há especulações, no entanto, no sentido de que havia ao menos outra forma de exploração coletiva que rivalizava com a societas. Era a denominada servus communis. A referida organização consistia no destaque de um patrimônio de um senhor (dominus), espécie de patrimônio de afetação, que passava a ser administrado por um escravo no exercício de determinada atividade empresarial. O escravo tornava-se uma espécie de órgão do dominus para a exploração da empresa. E como havia a possibilidade de vários dominus contribuírem para a formação deste patrimônio destacado, a fórmula per servus communis também prestava-se para a exploração coletiva da empresa. Esta era uma forma de proteger os credores e, de certa forma, restringi-los ao patrimônio afetado. Por esta razão, essa pode ter sido uma das fórmulas precursoras da limitação da responsabilidade. (MARRONE, Matteo. Instituzioni di diritto romano. 8. ed. São Paulo: Saraiva, 1995). Ainda a este respeito: "Antes de entrar no tema específico do presente estudo e consequentemente na exegese das fontes propriamente ditas é necessário fazer algumas considerações breves sobre uma recente tese surgida na doutrina romanística. O problema é relevante porque as dúvidas levantadas incidem sobre um dos pressupostos principais desta pesquisa, qual seja, o de que a societas seja o principal instrumento organizativo do fenômeno emprenditorial coletivo em Roma antiga, e que seja portanto a forma organizativa a ser comparada com as soluções modernas. O trabalho de Di Porto ao contrário, apesar de partir de um pressuposto não muito diverso, chega a conclusões totalmente opostas. Na verdade o autor conclui que a solução per servus communis é qualitativamente melhor que a societas como instrumento organizativo da empresa coletiva. Quatro seriam as desvantagens da solução societária: a não relevância externa da societas como regra (apesar de o autor reconhecer as exceções acima referidas - nota 7), a não formação de um patrimônio emprenditorial separado, a responsabilidade ilimitada de todos os sócios, e a instabilidade do vínculo societário, ou seja a possibilidade de sua dissolução por morte ou capitis dimunutio de um dos sócios. Partindo de uma tal avaliação "qualitativa" o autor deduz a prevalência "quantitativa" da solução per servus communis. Tal conclusão é criticável. Em primeiro lugar, do ponto de vista metodológico: não parece, na verdade, historicamente muito exato deduzir uma superioridade quantitativa simplesmente de uma suposta superioridade qualitativa. Em segundo lugar, é muito duvidoso que em uma sociedade em que o escravo ocupa o último lugar na escala social, a empresa seja organizada em torno de sua "capacidade organizativa e emprenditorial", enquanto o dominus aparece como um mero prestador de capital. Assim sendo, parece correto manter a hipótese inicial da societas como instrumento organizativo principal da empresa em Roma antiga. Mais precisamente, a societas unius alicuis negotii. (SALOMÃO FILHO, Calixto. "Societas" com relevância externa e personalidade jurídica. Revista de Direito Mercantil, Industrial, Econômico e Financeiro, n. ${ }^{\circ}$ 81, São Paulo, RT, 1991, p. 66-78).

${ }^{14}$ Como exemplo, podemos mencionar a existência das sociedades universais e sociedades particulares. Dentre as sociedades universais haviam: (i) a Societas Omnium Bonorum, nas quais os sócios colocam em condomínio todos os seus bens presentes e futuros para a consecução de um fim patrimonial comum; (ii) 
A societas romana, tipicamente agrária, foi modificada com o passar dos tempos em decorrência do crescimento do comércio e das recorrentes conquistas dos romanos, que invadiam áreas e dominavam populações para a formação do Império Romano.

Além disto, a posição geográfica estratégica de Roma estimulou o surgimento de múltiplas espécies de comércio, já que possibilitava a convergência de mercadorias e de pessoas de todo o mundo.

Os códigos romanos passaram a refletir as consequências do desenvolvimento do comércio. É importante notar que, conforme será tratado abaixo, a maioria dos juristas defende que inexistia o direito comercial na época romana e que tal conjunto organizado de normas só veio a ser criado e desenvolvido na Idade Média.

O expansionismo territorial de Roma e o seu enriquecimento transformaram a sociedade agrária em sociedade capitalista. Do referido fato resultou a luta entre a aristocracia e a plebe, que permeou a história de Roma durante longo período. ${ }^{15} \mathrm{~A}$ sociedade romana deste novo período moldurou-se com uma característica necessária à captação de crédito bancário: a solidariedade entre seus membros.

a Societas Universorum Quae ex Questu Veniunt, na qual os sócios conservavam um patrimônio particular, mas destinavam ao patrimônio comum o produto futuro de seu trabalho, excluindo-se os bens presentes e futuros adquiridos a título gratuito. Já dentre as sociedades particulares, destacam-se: (i) a Societas Unius Alicuis Negotii, que engloba todas as sociedades cujo objeto diz respeito ao exercício de uma atividade comercial ou de manufatura, sem ênfase no grau de complexidade da organização, (ii) a Societas Alicuius (Unius) Rei, que eram sociedades para exploração de um determinado escopo, que extinguia-se após exaurido o objeto específico para o qual foi constituída, (iii) a Societates Publicanorum ou Societas Vectigalis/Vectigalium, que tinham por objeto a assunção e exercício de atividades públicas e a arrecadação de impostos por meio de sociedade de publicani. A maioria da doutrina entende que a Societates Publicanorum ou Societas Vectigalis/Vectigalium possuíam personalidade distinta das pessoas físicas que a compunham. Waldemar Ferreira, ao tratar da existência transitória da Societas Alicuius (Unius) Rei, tece uma comparação com as sociedades em conta de participação. No entanto, não concordamos com a referida tese, já que está superada a discussão a respeito do caráter transitório das sociedades em conta de participação. Ao que parece, as Societas Alicuius (Unius) Rei são semelhantes às sociedades de propósito específico previstas no artigo 981, parágrafo único do Código Civil de 2002.

A respeito dos tipos de societas, vide FERREIRA, Waldemar. Idem, p. 120-123 e MOREIRA ALVES, José Carlos. Idem, p. 531. A respeito das societas, é importante mencionar as discussões doutrinárias a respeito da relevância externa do vínculo societário no direito romano. A este respeito, vide texto do professor Calixto Salomão (SALOMÃO FILHO, Calixto. Idem, p. 66-78).

${ }^{15}$ Conforme FERREIRA, Waldemar. Op. cit., p. 143. 
Mesmo após o esfacelamento do Império Romano, a sua cultura jurídica persistiu e, não obstante as mudanças políticas e sociais, a societas influenciou sobremaneira as sociedades medievais.

No entanto, com a nova realidade econômica e social marcada pelo desenvolvimento do comércio terrestre e marítimo, pelas grandes descobertas de territórios desconhecidos e de inventos industriais, as organizações estruturadas pelo sistema romano tiveram que se adaptar e se modificar.

A menção à societas romana é importante pelo fato de demonstrar que a ideia de sociedade já existia desde o direito romano, apesar de não apresentar todas as características encontradas nas atuais sociedades. ${ }^{16}$

\section{II.1.3 Sociedades comerciais medievais}

O desenvolvimento das sociedades comerciais medievais ocorreu de forma paralela ao próprio desenvolvimento da sistematização do direito comercial. Isto porque, de acordo com a posição dominante dos juristas e historiadores, o sistema de direito comercial - entendido como uma série de normas coordenadas a partir de princípios comuns, e não apenas como normas comerciais particulares à matéria comercial - surgiu na Idade Média, nas comunas, como meio de afirmação da burguesia em contraposição à civilização feudal. ${ }^{17} \mathrm{Da}$ mesma forma, a posição doutrinária dominante é no sentido de que as sociedades comerciais surgiram na Idade Média. ${ }^{18}$

\footnotetext{
${ }^{16}$ Conforme Rachel Sztajn, que menciona, ainda, que: "No direito romano clássico a palavra societas indicava o vínculo obrigatório, resultante do consenso - a sociedade, ao lado da venda, da locação e do mandato, constituía um dos quatro tipos de contratos consensuais do direito romano (contrato indica, genericamente, acordo de vontades idôneo para criar obrigações). A passagem de sentido da ideia de sociedade como vínculo obrigatório do direito romano clássico para o atual sentido de negócio jurídico consensual sobreveio por influência do direito natural, de um lado, e do direito comercial, de outro. $\mathrm{O}$ primeiro contribuiu pela valorização atribuída à vontade, o outro pela supressão da exigência de formas solenes para a conclusão de contratos. (SZTAJN, Rachel. Contrato de sociedade e formas societárias. São Paulo: Saraiva, 1989. p. 35).

17 "É na civilização das comunas que o direito comercial começa a afirmar-se, em contraposição à civilização feudal, mas também distinguindo-se do direito romano comum, que quase simultaneamente, se constitui e se impõe. O direito comercial aparece, por isso, como um fenômeno histórico, cuja origem é ligada à afirmação de uma civilização burguesa e urbana, na qual se desenvolve um novo espírito empreendedor e uma nova organização dos negócios. Essa nova civilização surge justamente, nas comunas italianas" (ASCARELLI, Tulio. Corso di Dirrito Commerciale - Introduzione e Teoria dell'a
} 
As invasões bárbaras e consequente queda do Império Romano favoreceram, sensivelmente, as mudanças econômicas e sociais, além de alterar o sistema de propriedade e de produção. Isto em razão do surgimento do feudalismo, fundado no trabalho livre - em contraposição à economia servil romana - e na organização da propriedade agrária, o que ensejou o retrocesso da civilização francoromana à vida agrícola.

Aos poucos a produção agrícola realizada em meio feudal passou a ser alvo de consumo e trocas. Também, de forma gradual, a produção industrial teve início.

Assim, a cidade comunal tornou-se um centro de consumo e de trocas, fomentada pela realização de feiras e mercados. As feiras constituíam pontos de encontro e de trabalho, onde se aplicava o direito criado pelos próprios comerciantes que acabou por descolar-se do direito comum aplicado no domínio feudal. O conjunto de normas costumeiras e generalizadas criadas pelos artesãos e comerciantes

Impresa. 3. ed. Milão: Giuffrè, 1962. Traduzido por COMPARATO, Fábio Konder. Origem do Direito Comercial. Revista de Direito Mercantil, Industrial, Econômico e Financeiro n. ${ }^{\circ}$ 103. São Paulo: Malheiros, 1996. p. 87-100). "É na Idade Média que se situa a origem das sociedades comerciais, período em que se assinala a existência das compagnias (sociedades gerais ou coletivas). Estas tinham origem familiar e nela todos tinham a representação e respondiam pessoal e solidariamente pelos atos praticados em nome da sociedade, compartindo os riscos da atividade". (FRANCO, Vera Helena de Mello. As sociedades de pessoas na atualidade. Uma visão comparativa crítica. Revista de Direito Mercantil, Industrial, Econômico e Financeiro, n. ${ }^{\circ}$ 157, p. 93-111, São Paulo, Malheiros, 2011). "A Idade Média, com a queda do império romano, assinala o período da formação do direito comercial.

O comércio e a indústria, sob o influxo das ideias do Cristianismo, travaram, em bem da sua liberdade e desenvolvimento, luta renhida contra as velhas instituições políticas e contra a inflexibilidade, rigidez e franqueza das regras do romano, o jus commune, que, por muitos séculos, auxiliado pelo jus gentium, bastou a prover as exigências do tráfico comercial. À medida que tomavam impulso as transações se amiudava o comércio marítimo, e se desenvolvia o crédito, paralelamente àquele direito apareceram nas Repúblicas da Itália, como Veneza, Gênova, Pisa, Florença etc., os usos e costumes, seguidos no trato dos negócios (stylus mercatorum), primeira manifestação jurídica do exercício do comércio. Em começo, os usos vieram suprir a insuficiência dos textos romanos, regendo casos novos. Depois deram batalha franca a esses textos, estreitos, incompatíveis com a ordem incipiente de fatos, que reclamavam especial disciplina jurídica. (...) O direito comercial surgiu, conforme se vê, não como obra legislativa nem criação de jurisconsultos, porém, como trabalho dos próprios comerciantes, que o construíram com os seus usos e com as leis, que, reunidos em classe, elaboraram." (MENDONÇA, José Xavier Carvalho de. Tratado de direito comercial brasileiro. v. I. livro I. Rio de Janeiro: Freitas Bastos, 1963. p. 54-56).

${ }^{18}$ Pontue-se, no entanto, que para alguns as sociedades comerciais remontam à Roma: "La plupart de societés étaient des societés simplistes qui rappelent surtout les societés de l'époque romaine." (ROYER, Copper. Traité des Societés. Paris: Librairie du Recueil Sirey, 1938). "Confronto com a societas romana - Na Itália, como mencionado, ela persiste na nova roupagem de compagnia medieval, a qual, mais uma vez na lição de Brunetti, vai se distinguir da societas romana por três características essenciais: $1^{\circ}$ ) a finalidade do lucro, que é sua força propulsora; $2^{\circ}$ ) pelo regime de responsabilidade solidária de seus membros; $3^{\circ}$ ) pelo exercício da empresa em nome próprio. Já perante a comunidade familiar da sua origem, o traço distintivo é a presença da affectio societatis que substitui o vínculo fraternitatis." (FRANCO, Vera Helena de Mello. Idem, ibidem). 
denominava-se lex mercatoria ou ius mercatorum, direito do mercado, misto de público e de privado, pois era aplicado à ordem interna e administrativa dos mercados e às relações entre os comerciantes. ${ }^{19}$

As cidades marítimas, por sua vez, tinham no mar a via de troca em transações de longa distância, e o ius mercatum, bem como o costume dos comerciantes propagavam-se e impunham-se em nível internacional. ${ }^{20}$

No que se refere aos aspectos jurídicos relacionados ao tema, $\mathrm{CARLI}^{21}$ aduz que nas cidades marítimas o contrato típico era o que ligava comerciante ao capitalista, o qual permanecia no seu posto (commenda ou societas maris - que posteriormente fundamentou as sociedades em comandita simples e as sociedades em conta de participação).

Nas cidades de terra firme, por sua vez, as sociedades comerciais derivaramse dos acordos em família e suas atividades comerciais e regulares tinham caráter de estabilidade e de permanência (compagnia - que posteriormente deu fundamento às sociedades em nome coletivo). ${ }^{22}$

As diversas relações jurídicas do período medieval confluíram na commenda, tanto agrícola como marítima. Tem-se nela o embrião da sociedade em comandita e da sociedade em conta de participação. O empréstimo de terras e de sementes para plantio e colheita, ou de animais para engorda, reprodução e venda, bem assim o de dinheiro ou a entrega de coisas móveis a fim de revenderem em terras

\footnotetext{
${ }^{19}$ Conforme FERREIRA, Waldemar. Op. cit., p. 164.

"É, na origem, o ius mercatorum ou lex mercatoria, e é tal não só porque regula a atividade dos mercatores, mas também e sobretudo porque é direito criado pelos mercatores, que nasce dos estatutos das corporações mercantis, do costume mercantil, da jurisprudência da corte dos mercadores." (GALGANO, Francesco. Lex mercatoria (Introdução, Item 1). Traduzido por FRANÇA, Erasmo V. A. N. Temas de Direito Societário, Falimentar e Teoria da Empresa. São Paulo: Malheiros, 2000. p. 640).

20 "Quanto às cidades marítimas, elas tinham no mar uma via de comunicação para horizontes mais largos e um incentivo aos negócios especulativos por meio de trocas a longa distância, que engendravam ao mesmo tempo riscos, riquezas e experiências" (ASCARELLI, Tulio. Corso di Dirrito Commerciale... cit., p. 87-100).

${ }^{21}$ CARLI, Filipo. Estoria del commercio italiano: il mercato nell'ed del comune. v. II. Pádua: Cedam, 1936. p. 203.

${ }^{22}$ Em sentido contrário, vide GOLDSCHIMIT, que entendia que a commenda emprestou seu esquema às sociedades comerciais de terra firme (GOLDSCHIMIT, Levin. Storia universale del diritto commerciale. Tradução de POUCHAIN, Vittorio; SCIOLOJA, Antonio. Milão, Nápole, Palermo e Roma: UTET, 1913).
} 
distantes geraram os referidos tipos societários. ${ }^{23}$ Portanto, as condições econômicas exigiram que os capitais e o trabalho se conjugassem em novas fórmulas jurídicas, aptas ao desenvolvimento e à segurança do tráfico mercantil com o fim de assegurar os recursos financeiros vertidos para as explorações mercantis. ${ }^{24}$

Tal resultado foi alcançado mediante a adoção do princípio da solidariedade dos sócios pelas obrigações por eles assumidas em comum, mas tornou-se premente a necessidade de submeter às organizações medievais a disciplina corporativa para o fim de se definir e apurar responsabilidades. Logrou-se isto com o registro de determinadas organizações medievais na matrícula das corporações dos mercadores ou dos tribunais consulares. Desta forma, as organizações medievais adquiriram corpo e autonomia, distanciando-se do conceito e do tipo de societas romana. ${ }^{25}$

A sociedade em nome coletivo é a primeira espécie de sociedade comercial. $^{26}$

Além da sociedade em nome coletivo, a sociedade em comandita e a sociedade em conta de participação são espécies de sociedades comerciais medievais.

\footnotetext{
${ }^{23}$ Conforme FERREIRA, Waldemar. Op. cit., p. 168.

${ }^{24}$ A professora Rachel Sztajn preconiza: "O processo de formação dos costumes mercantis, que pode ser buscado na Idade Média, resulta da adoção, por dois comerciantes, de uma certa forma de regulação de seus negócios que, mantida e utilizada por largo espaço de tempo, torna-se hábito e passa a ser subentendida em todos os negócios por eles realizados, sem que haja necessidade de sua expressa menção a cada nova operação. Generalizada a prática, empregada por outros comerciantes, em outras praças, em outros negócios ou ramos do comércio, surge o "uso". Aliás, as ditas cláusulas de estilo nada mais são do que embrião do uso. Sabendo-se que a origem das sociedades comerciais não está ligada à societas romana, seu aparecimento pode ser vinculado aos usos e costumes comerciais. A prática de os filhos do comerciante falecido continuarem a exercer, em conjunto, o negócio do pai, como sócios iguais, deu origem à sociedade em nome coletivo, companhia ou societas fratrum, decorrente do uso que se estabeleceu de os herdeiros manterem a atividade exercida anteriormente pelo ascendente falecido. (SZTAJN, Rachel. Contrato de sociedade... cit., p. 23-24).

${ }^{25}$ Conforme FERREIRA, Waldemar. Op. cit., p. 169.

${ }^{26}$ Divergiu quanto a isso Goldschimit, para quem antes das sociedades em nome coletivo os comerciantes teriam se servido da sociedade em comandita simples. (GOLDSCHIMIT, Levin. Op. cit.).

A este respeito, vide Waldemar Ferreira: "Se as circunstâncias de ordem econômica geraram a commenda, ou seja, a entrega de dinheiro a alguém, a fim de aplicá-lo em negócios e repartirem-se os lucros, correndo o capitalista os riscos do empreendimento; se tal forma contratual, de vetusta origem, ao depois se vulgarizou, tanto que se recolheram nos códigos romanos os preceitos que a disciplinaram - tem isso servido de fundamento para a tese de que a sociedade em comandita simples foi a primeira das sociedades mercantis e suas raízes se encontram no nauticum foenus. Tem sido ela amplamente discutida. Encontrou opositores inúmeros. A primazia, para este, pertence à sociedade em nome coletivo. (FERREIRA, Waldemar. Op. cit., p. 160).
} 
Tendo em vista o objeto deste trabalho, trataremos abaixo da origem da sociedade em conta de participação, espécie do gênero sociedade comercial medieval.

\section{II.2 Origem da sociedade em conta de participação: contrato de comenda}

Há controvérsias quanto ao exato momento do surgimento da sociedade em conta de participação. A construção de uma posição doutrinária a esse respeito parte de distintos relatos históricos.

O jurista MARGHIERI, por exemplo, menciona que a história do comércio está intrinsecamente relacionada com institutos jurídicos semelhantes à sociedade de participação e que, portanto, os comerciantes, em todos os tempos, valeram-se de institutos semelhantes ao ora analisado. ${ }^{27}$

Ainda, há juristas que recuam a existência das sociedades em conta de participação ao período do apogeu romano. ${ }^{28}$

No entanto, a posição dominante é no sentido de que a sociedade em conta de participação nasceu na Idade Média, na Itália, no período das decisões da Rota de Gênova em decorrência da proibição da usura pela Igreja Católica e do clima medieval, que dificultava o exercício do comércio pelos nobres.

Os juristas que defendem a posição dominante relatada acima remetem a origem da sociedade em conta de participação ao contrato de commenda.

O contrato de commenda, largamente utilizado nas cidades italianas durante a Idade Média, possuía como característica predominante o fato de que um dos contratantes, denominado “commendator”, realizava sua prestação de forma a entregar

\footnotetext{
27 "La pratica commerciale di tutti i tempi offre esèmpio delle associazioni in participazione, e la dottrina non há mancato di aceratre questo fato, ricercandone la prova dll'esistenza nei piu antiché tempi" (MARGHIERI, Alberto. Società e associazione commerciale. Nápole: Eugenio Marghieri, 1921).

${ }^{28}$ Como exemplo, vide José Xavier Carvalho de Mendonça: "Se bem que as leis romanas não the fizessem referência especial, houve quem reconhecesse em Roma essa espécie de contrato, afirmando o seu uso. Os imperadores Diocleciano e Maximiniano falaram de uma participação num arrendamento de salinas" (MENDONÇA, José Xavier Carvalho de. Tratado de direito comercial... cit., 1959, p. 224).
} 
recursos financeiros ou mercadorias para que o outro contratante, denominado "tractator", as negociassem. Como exemplo clássico do contrato de commenda, é possível mencionar o contrato celebrado entre proprietários ou capitães de navio e um terceiro investidor. Por meio dos referidos contratos, largamente utilizados no comércio marítimo da época, o proprietário e/ou capitão do navio adquiriam, negociavam, transportavam e vendiam mercadorias compradas com os recursos financeiros disponibilizados pelo terceiro investidor. ${ }^{29}$

O pólo contratante formado pelo proprietário e/ou capitão do navio fornecia a força de trabalho necessária para a aquisição, negociação de mercadorias e o seu transporte marítimo para, finalmente, efetuar a venda dos produtos no mercado estrangeiro. De outro lado, o outro pólo do contrato era formado pelo investidor. Portanto, havia uma parte investidora e outra parte gestora.

Diante disto, é possível afirmar que o risco do commendator estava limitado ao montante do aporte de recursos financeiros empregados no negócio. Já o risco do tractator era mais amplo e incluía os riscos inerentes à administração do negócio, além dos recorrentes problemas enfrentados pelos comerciantes nos transportes marítimos realizados à época, dentre os quais incluíam-se os recorrentes ataques de piratas e problemas com intempéries do clima e do mar. Em outras palavras, é possível afirmar que a responsabilidade do commendator estava limitada ao montante aportado, enquanto a responsabilidade do tractator poderia até mesmo alcançar, de forma ilimitada, os seus bens pessoais.

A diferenciação entre a responsabilidade do commendator e do tractator constitui o início da limitação da responsabilidade nas sociedades comerciais medievais,

\footnotetext{
${ }^{29} \mathrm{Na}$ lição de Mendonça: "O contrato de commenda ou de paccotiglia, muito usado nas cidades comerciais italianas dos séculos XII e XIII", era aquele "mediante o qual se entregava a quem ia empreender viagem marítima certa quantia em dinheiro ou mercadoria, para que com estes efeitos negociasse, em nome próprio, mas em proveito comum, conforme o ajuste. Desse modo, qualquer que fosse o êxito do negócio confiado àquele que empreendia a viagem (tractator, commanditarius), o que entregava o dinheiro ou as mercadorias (commendator, socius stans) não se responsabilizava além do valor entregue." (MENDONÇA, José Xavier Carvalho de. Tratado de direito comercial... cit., 1963, p. 172).
} 
muito embora, conforme será abordado abaixo, em um primeiro momento, o contrato de commenda ainda não era caracterizado como contrato de sociedade. ${ }^{30}$

\section{II.2.1 Tipos de contrato de comenda}

Há, ao menos, dois tipos de commendas que podiam ser identificados na Itália e na Espanha durante a Idade Média.

Na primeira espécie, o contratante investidor aportava recursos financeiros, enquanto o contratante gestor administrava o negócio, disponibilizava a sua força de trabalho e viabilizava a entrega de mercadorias via viagem marítima. No referido contrato de commenda, o investidor recebia os lucros do negócio, enquanto que o gestor recebia uma comissão em contrapartida à execução de seu trabalho. Nesta espécie, denominada commenda com aporte unilateral de capital, em regra, o tractator recebia 1/4 (um quarto - quarta proficui) dos lucros como remuneração pelos trabalhos prestados.

Já a segunda espécie é caracterizada pelo fato de que ambos os contratantes investiam recursos financeiros no negócio, sendo certo que uma das partes também era responsável pela gestão da viagem marítima e efetiva venda das mercadorias. Nesta espécie, os lucros do negócio eram distribuídos entre ambos os contratantes. Em geral, o commendator participava com 2/3 (dois terços) do capital e o tractator com 1/3 (um terço). Considerando, entretanto, que neste caso o tractator também recebia a remuneração pelo trabalho desempenhado, no montante de 1/4 (um quarto, quarta proficui), ao final os lucros eram repartidos igualmente entre as partes. ${ }^{31}$

\footnotetext{
${ }^{30}$ A este respeito: "Considerando as estreitas relações dos fenômenos jurídicos com os políticos e a grande transformação política e econômica da época seguinte à agonia de Roma e de Bizâncio e das invasões bárbaras, observou Paul Guidot terem duas causas favorecido o desenvolvimento medieval da comenda, focalizando pontos já anteriormente passados em revista: a) o novo princípio, por ela introduzido, mercê da qual, contrariamente ao direito comum, que exigia a responsabilidade solidária e in infinitum dos sócios de sociedade mercantil, êstes não responderiam senão pessoalmente e no limite de suas contribuições; b) a proibição canônica da usura, que deu em resultado a comenda bilateral, convertendo o prestador de capital em sócio." (FERREIRA, Waldemar. Tratado de sociedades mercantis. 5. ed. São Paulo: Livraria Freitas Bastos S/A, 1958. p. 199).

${ }^{31}$ LATTES, Alessandro. Il diritto commercial nella legislazione statutaria delle città italiane. Milano: Ulrico Hoepli, 1884. p. 159.
} 
O jurista REHME menciona que a espécie na qual apenas o contratante investidor aportava recursos financeiros é mais antiga e constitui o típico contrato de commenda. A segunda espécie, por meio da qual ambos os contratantes aportam recursos financeiros era denominado de societas. De toda forma, REHME já mencionava a existência de efetiva sociedade em ambas as espécies. ${ }^{32}$

GOLDSCHMIDT, ${ }^{33}$ no entanto, defende que a commenda com aporte unilateral de capital era chamada prevalentemente de collegantia (em Veneza) ou societas (maris/terrae), mas também era designada pelo termo geral de commenda. Por outro lado, o termo societas também era utilizado para a commenda com aporte bilateral de capital.

Existiam, entretanto, outras inúmeras espécies, em que se estabelecia inclusive a participação nas despesas e investimentos, bem como a recondução do lucro do tractator ao capital originário, o que implicava uma crescente conta de capital. ${ }^{34}$

Entre as mesmas pessoas existiam diversas societates, contemporâneas ou subsequentes. No início, cada commendator tinha apenas um tractator e este necessitava de autorização para carregar em sua viagem outras mercadorias além daquelas contratadas. ${ }^{35}$ Posteriormente, entretanto, tornou-se usual um mesmo tractator - agora mais independente - receber capitais e mercadorias de diversos investidores, mantendo com cada um deles relação jurídica distinta das demais. ${ }^{36} \mathrm{O}$ commendator e o tractator passaram também a empregar o capital de terceiros com os quais eles mantinham outras relações jurídicas - por exemplo, como tutores ou maridos. ${ }^{37}$

Muitas vezes, observava-se que o commendator era também um tractator em outros negócios, e que o tractator, por sua vez, tinha a faculdade de subcontratar. ${ }^{38}$

\footnotetext{
${ }^{32}$ REHME, Paul. Historia universal del Derecho mercantil. Madrid: Revista de Derecho Privado, 1941. p. 83 . 
A partir das inúmeras variações, obtinha-se economia de escala e também a dispersão de riscos. ${ }^{39}$

Havia liberdade para a definição de como seria empregado o capital investido. Ora o capital era dado para uma especulação precisamente determinada (bens para a venda, dinheiro para a compra) e também para a viagem de ida e volta, mas também era confiado para uma série indeterminada de negócios por tempo determinado ou indeterminado, com ou sem instrução precisa e também segundo a livre apreciação do tractator ou de terceira pessoa - mandatário. ${ }^{40}$

No processo de evolução da commenda unilateral e marítima para sua forma bilateral e terrestre e, posteriormente, para a sociedade em comandita simples e para a sociedade em conta de participação, destaca-se a figura da societas maris.

No referido tipo de contrato, que pode ser considerado uma commenda bilateral, o tractator aportava 1/3 (um terço) do capital e o commendator aportava 2/3 (dois terços) do capital e as mercadorias - de ambos - eram postas no navio "em conjunto", o que fez com que o tractator passasse a dividir o risco com o commendator. Esta divisão de riscos, e não propriamente a divisão de resultados ou de custos, é que distingue a societas maris dos demais contratos e, em razão dela, começa a se formar um fundo separado e comum, com projeção externa. ${ }^{41}$

Pelo modelo de societas maris existente em Gênova e utilizado em todo o Mediterrâneo, o commendator tinha privilégio sobre os bens entregues à commenda ou adquiridos com os recursos provenientes da commenda.

\footnotetext{
39 "The commenda had several variations. A basic variant according to Raymond and Lopez (2001) was one in which the traveling party also invested money, typically a third of the investment. This affected the splitting of profits. In a second variant, the traveling party could, if not prohibited, create a second commenda in which he placed all or part of the goods in the hands of a third person who traveled to a more distant market. The traveling party of the first commenda became the investing party of the second. Another variation was that the commenda assets could be not only distinct goods but also a share in a pool of goods or in a ship. The bilateral commenda could appear as part of a complex multilateral system. For example, a single traveling party could pool together goods from numerous investing parties into a commenda. This would allow him, and them, the benefits of economy of scale. Conversely, an investing party could split his investment among several traveling parties. This would serve as a method of risk spreading." (HARRIS, Ron. The institutional dynamics of early modern eurasian trade: the commenda and the corporation. Disponível em: < http://ssrn.com/abstract=1294095>. Acesso em: 25 abr. 2012).

${ }^{40}$ GOLDSCHIMIT, Levin. Op. cit., p. 208 e LATTES, Alessandro. Op. cit., p. 158.

${ }^{41}$ WEBER, Max. Op. cit., p. 69-70.
} 
De tal fato decorria, segundo WEBER, ${ }^{42}$ que: (i) esses ativos não podiam ser utilizados para a satisfação de credores do tractator, que somente poderiam requerer parte dos lucros da commenda em caso de quebra; (ii) os credores pessoais do socius stans (commandator) não podiam se voltar diretamente contra o fundo separado da commenda, cabendo demandar apenas que o tractator liberasse os valores investidos ou os lucros que lhes fossem destinados.

Já em Pisa, esse fundo comum e separado da societas maris era denominado de hentica, segundo o constitum usus e impunha as seguintes consequências: (i) os sócios podiam intervir e demandar a liberação dos bens atingidos em caso de credores que não tinham um contrato em que a hentica era responsável, isto é, em caso de credores pessoais do tractator; (ii) em caso de vários socii stantes relacionados a um tractator, considerava-se que eles detinham os ativos investidos em comum e deviam dividi-los de acordo com a quota de cada um. Consequentemente, em caso de quebra, nenhum deles tinha o direito de satisfação privilegiado com base na sua contribuição e nem podia requerer a devolução da sua contribuição in natura. Em suma: os ativos investidos não eram considerados mais propriedade individual; lucros e perdas deveriam ser suportadas todas em conjunto, proporcionalmente aos valores investidos; (iii) os credores do tractator por dívidas adquiridas no exercício da societas maris não eram credores dos socii stantes. Em caso de quebra, eles detinham privilégio de satisfação dos seus créditos diretamente contra a hentica; (iv) os ativos conferidos pelas partes só se consideravam incorporados ao fundo (hentica) após terem o seu valor estabelecido, de forma que o valor do bem era creditado no fundo, não o bem em si. ${ }^{43}$

Por fim, destaca-se que, na Idade Média, era corrente a noção de que a commenda tinha natureza de sociedade, muito embora uma análise segundo uma perspectiva atual conduza à conclusão de que se tratava de contrato distinto do contrato de sociedade. ${ }^{44}$

\footnotetext{
${ }^{42}$ Idem, p. 75-78.

${ }^{43}$ WEBER, Max. Idem, p. 131-134.

${ }^{44}$ MIGNONE, Gianni. Un contratto per i mercanti del mediterrâneo. L'evoluzione del rapporto partecipacivo. Napoli: Jovene, 2005. p. 90-101.
} 


\section{II.2.2 Desenvolvimento e publicidade dos contratos de comenda}

A utilização dos contratos de commenda deixou de se restringir apenas aos negócios relacionados ao comércio marítimo e passou a abranger também os negócios relacionados ao comércio terrestre. Desta forma, o contrato de commenda passou a ser utilizado por maior número de comerciantes e até mesmo por pessoas que ambicionavam obter lucros, mas, ao mesmo tempo, eram inaptas para o exercício do comércio ou sustentavam aversão à sua prática, já que, este não era visto como uma atividade digna da nobreza. Portanto, inclinam-se os autores a asseverar que, embora inicialmente cunhado para viabilizar os negócios marítimos, o contrato de commenda passou, posteriormente, a ser utilizado também em terra. ${ }^{45}$ Dizia-se, então: "portat (trans mare...in terra) laboratum," ou seja, fazer trabalhar o dinheiro com escopo de lucro. Há quem pondere, entretanto, que tal tese não procede, pois o contrato de commenda é universal, decorrente da associação entre capital e trabalho. ${ }^{46}$

Além disto, outro fator importante, que deve ser considerado para o desenvolvimento do contrato de commenda, diz respeito à famigerada proibição da usura pela Igreja da Idade Média. Na época, dizia-se que o contrato de commenda era um contrato de mútuo disfarçado, pois o capital investido no negócio poderia ser

Entre os autores mais recentes que tratam a commenda como sociedade estão: LATTES, Alessandro. Op. cit., p. 154 e ss e REHME, Paul. Op. cit., p. 82-83. Este último autor assevera que a commenda era uma sociedade, ainda que segundo a concepção de direito da época.

${ }^{45}$ Seguindo a lição de Goldschmidt (GOLDSCHIMIT, Levin. Op. cit., p. 210).

${ }^{46}$ REHME, Paul. Op. cit., p. 82.

Vide também: "Alguns institutos praticaram-se, de natureza associativa, como formas societárias havidas por grande número de escritores, originárias, quase todas, do comércio marítimo.

Referindo-se aos estudos de Sayous, escreveu Filippo Carli, ao tratar do influxo do comércio marítimo sobre os métodos do comércio terrestre, que, nas cidades marítimas, o contrato típico era o que ligava comerciante a capitalista, o qual permanecia no seu posto (commenda, ou societas maris); nas cidades de terra firme, em vez, o que, derivado dos acordos em família (compagnia) reservava lugar, em atividade comercial e regular, a empregados ou a competências reconhecidas e tinham, dessarte, caráter de estabilidade e de permanência. Desarrazoado foi Goldschimidt, no sentir do tratadista, ao afirmar que a commenda emprestou o seu esquema às sociedades comerciais de terra firme; ao contrário, a origem familiar da sociedade comercial ordinária é confirmada pelo número considerável das que existiram em 1121-29, em Siena, entre parentes.

Bateram neste ponto Cooper Royer, mas concluindo diversamente. Formaram-se eles sob diversas regras, que usos ancestrais ou certas necessidades acabaram por tornar em toda parte idênticos e comuns, societates maris, que receberam muitas vezes o qualificado de societates fratrum, não tanto porque compreendessem sócios pertencentes à mesma família, mas porque os riscos de morte ou de escravidão, corridos em comum durante a travessia, estabeleciam comunidade de esforços e angústias, geratrizes mais seguras de temporária confraternidade do que laços de sangue." (FERREIRA, Waldemar. Op. cit., p. 168). 
caracterizado como um empréstimo ao negociante, que deveria ser restituído ao investidor acrescido de taxa de juros.

Para evitar ou impedir eventual sanção do poder canônico e para evitar a caracterização dos contratos de commenda como contratos de mútuo, bem como para conferir maior transparência aos referidos contratos, determinados comerciantes passaram a registrá-los. E, ainda, em alguns casos, para o fim de evitar fraude a terceiros, o registro dos contratos de commenda passou a ser exigido por lei. Como exemplo, é possível mencionar a Lei de Florença de 1408, que previa que os sócios das comanditas deveriam depositar seus respectivos nomes nos registros corporativos.

No entanto, a publicidade não interessava a todos que desejavam investir neste tipo de negócio, pois, muitos deles, apesar de ambicionar obter lucro, não se sentiam à vontade para exercer o comércio mediante a indicação pública de seu nome, já que o exercício do comércio era considerado vexatório.

Ademais, a possibilidade de se manter a identidade de um dos sócios secreta perante terceiros despertou interesse dos comerciantes da Idade Média, já que os riscos de condenação pela prática de usura poderiam ser sensivelmente mitigados.

Logo, conforme menciona FRAN MARTINS, ${ }^{47}$ persistiram os contratos de commenda sem que os nomes dos sócios fossem depositados nos registros.

\section{II.2.3 Evolução dos contratos de commenda para a forma de sociedade e diferentes posicionamentos sobre a influência dos contratos de commenda para o surgimento das sociedades em conta de participação}

Decorrido algum tempo, o contrato de commenda passou a ser caracterizado como contrato de sociedade.

\footnotetext{
47 Conforme MARTINS, Fran. Curso de Direito Comercial: Empresa comercial, empresários individuais, microempresas, sociedades comerciais, fundo de comércio. 31. ed. Rio de Janeiro: Forense, 2007. p. 289.
} 


\section{II.2.3.1 Fatores}

A referida evolução de conceito e características decorreu da combinação de uma série de fatores.

No contrato de commenda com aporte bilateral de capital, o vínculo que unia as partes fazia-se cada vez mais estreito e não era mais necessário, como ocorria no contrato de commenda com aporte unilateral, fixar severamente os termos da viagem e a natureza da especulação que seria levada a cabo pelo tractator ${ }^{48} \mathrm{O}$ contrato de commenda, assim, vai deixando de se prestar a negócios ocasionais e ganha estabilidade, migrando, outrossim, do comércio marítimo para o comércio terrestre. ${ }^{49}$

Para GARRIGUES, ${ }^{50}$ é neste momento:

quando o contrato não se limita à especulação em uma só viagem, mas compreende várias e se estende a múltiplas operações comerciais reunindo um grande número de pessoas, contribuindo ademais o comanditado não só com seu trabalho, mas com o seu capital também, surge então o elemento social (communis negotiatio). Este elemento vem a integrar o antigo contrato, do qual se conserva viva a característica principal, ou seja, o limite das perdas para o commendator.

No contrato de commenda bilateral e depois no contrato de commenda terrestre, especialmente no bancário, o tractator ganha, diante de inúmeros fornecedores de capital uma posição dominante. Ao mesmo tempo, no interesse dos investidores, de um lado, e dos credores, de outro, começa-se a desenhar de modo mais nítido a separação do patrimônio social dos bens particulares dos sócios e se acrescenta a obrigação do registro e até mesmo de adoção de uma razão social. Essa transformação começa no século XV - a partir do Estatuto de Florença de 1408 - e não pode dizer-se completa até o século XVII, com a legislação de Luiz XIV - Ordenação do Comércio Francesa de $1.763 .^{51}$

\footnotetext{
${ }^{48}$ ARCANGELI, Ageo. Op. cit., p. 15.

${ }^{49}$ FERRARA, Francesco. Teoria delle persone giuridiche. Napoli: E. Marghieri, 1923. p. 533-534.

${ }^{50}$ GARRIGUES, Joaquin. Tratado de derecho mercantil. tomo I. v. I. Madrid: Revista de Derecho Mercantil, 1930. p. 578.

${ }^{51}$ GOLDSCHIMIT, Levin. Op. cit., p. 211-212. VIVANTE, Cesare. Trattato di diritto commerciale. (Le società commerciali). v. II Milano: Casa Editrice Dottor Francesco Vallardi, 1923. p. 125-126.
} 
Em virtude dos fatores expostos acima, o contrato de commenda passou a ter as características dos contratos de sociedade. Conforme passaremos a tratar no item abaixo, apesar da controvérsia existente, a maioria dos juristas defende que a evolução do contrato de commenda e o consequente surgimento do conceito de "sociedade" ensejaram o surgimento das sociedades em conta de participação.

\section{II.2.3.2 Origem das sociedades em conta de participação: diferentes posicionamentos}

No contexto exposto no item II.2.2, os contratos de commendas não registrados continuaram a ser utilizados, conservando a sua forma primitiva, à ilharga daquele outro (contrato de commenda registrado), praticando-se paralelamente com ele, mas sem manifestação exterior, oculto, desconhecido de terceiros, somente vigorando nas relações entre os contratantes. ${ }^{52}$ Assim, o lado dos contratos de commendas registrados e, portanto, públicos, outros contratos de commendas se mantiveram ocultos.

O entendimento de que as sociedades em conta de participação tiveram origem no contrato de commenda é dominante na doutrina estrangeira e pátria. ${ }^{53}$ No

\footnotetext{
${ }^{52}$ FERREIRA, Waldemar. Op. cit., p. 528.

53 Assim: "Na comenda vêem muitos autores a origem da conta de participação. GRANDI resume bem teorias diversas, de Schupfer, Navarrini, Vivante, Gasca, Lastig r Lattes, Renaud e Goldschmidt, Endemmann e Bosco, segundo os quais de vários modos se teria originado a conta de participação.

Assim, para Schupfer, "la commenda, società per lo più effimera ed avventizia, sorge del commercio marittimo e ala sua volta dà poi nascimento alle due forme parallele dela società in accomandita $e$ dell'associazione in partecipazione"; Navarrini, para o qual a conta de participação teve sua origem última na admissio romana, é de parecer que ela se firmou na Idade Média conjuntamente com a sociedade em comandita, e que as duas têm uma única origem, a comenda; já Vivante encontra a origem da conta de participação na comenda marítima e a da comandita na comenda terrestre; Gasca, ainda, deriva da comenda tanto "la società per via di accomenda", a comandita moderna, como a conta de participação, que também conservava o nome de comenda ou admissio ad participationem; Lastig, seguido por Lattes, distingue na comenda duas modalidades, uma sociedade unilateral de trabalho, em que o empreendedor, numa posição subordinada, prestava o seu trabalho, e outra sociedade unilateral de capital, de que se teria originado a conta de participação, em que o empreendedor, como commendans, tinha a posição principal, emprestando o seu capital ao accomandatarius; Renaud e Goldschmidt distinguem entre a comenda bilateral, de que veio a comandita, e a unilateral, que resultou na conta de participação; Endemmann sustenta que a comandita derivou da publicação da conta de participação; afinal, Bosco opina que a conta de participação e a comandita não derivam uma da outra, e afirma que se originaram em lugares diversos, a primeira em Genova, pelo uso comercial, e a segunda em Florença, por criação da lei, ambas representando reações contra a responsabilidade solidária de sócios.” (LOPES,
} 
entanto, há diferentes posicionamentos a respeito da efetiva influência dos contratos de commenda na origem das sociedades em conta de participação.

Para determinados autores, ${ }^{54}$ os contratos de commendas registrados deram origem à sociedade em comandita. Já os contratos de commendas que se mantiveram ocultos deram origem às sociedades em conta de participação, caracterizadas pelo sigilo acerca da existência do vínculo entre o investidor e o gestor.

Já para outros diversos autores, a bipartição do contrato de commenda em sociedade em comandita e sociedade em conta de participação decorreu dos papéis, deveres e responsabilidades efetivamente contratados e exercidos pelo commendator e tractator, de forma que a existência do contrato de commenda bilateral teria ensejado o surgimento da sociedade em comandita, enquanto que o contrato de commenda unilateral teria ensejado a sociedade em conta de participação.

Neste contexto, muitos historiadores e juristas entendem que o contrato de commenda se bipartiu em contrato bilateral e contrato unilateral. O contrato bilateral foi caracterizado por vínculos estreitos entre o capitalista e o gestor, assumindo este último o papel ostensivo e preponderante de dono do negócio, dominus negotti, sendo certo que neste tipo de contrato de commenda o gestor se concentrava na função subordinada laboral, sendo uma espécie de sociedade unilateral de trabalho. Já o contrato unilateral foi caracterizado como aquele em que a entrada do tractator consistia em sua indústria apenas, e era o tipo mais simples e primitivo do instituto, sendo uma espécie de sociedade unilateral de capital, em que o investidor empresta seu capital ao sócio que exerce o trabalho. ${ }^{55}$

Mauro Brandão. Ensaio sôbre a conta de participação no direito brasileiro. São Paulo: RT, 1964. p. 20).

${ }^{54}$ Como exemplo, Paulo Cavalcanti Salgado assevera que tanto a sociedade comandita quanto a sociedade em conta de participação tiveram desenvolvimento paralelo, sem que uma derive da outra. Para ele, o ponto central que as diferencia consiste na publicação: enquanto a comandita é exteriorizada a terceiros, pelos efeitos de registro, a sociedade em conta de participação não possui publicidade. (SALGADO, Paulo Cavalcanti. Das sociedades em conta de participação no direito comercial brasileiro. Recife: Imprensa Industrial, 1913. p. 23)

55 A este respeito, vide: “[...] vê-se, pois, segundo Caroselli, que na comenda estavam potencialmente presentes tanto a comandita como a conta de participação, a primeira na possibilidade de capital comum ao commendans e ao tractator, com a partilha dos lucros, e a segunda na possibilidade de capital entregue ao tractator, como dono do negócio, pelo commmendans, como mero participante. As duas formas da comenda foram, todavia, segundo ele, simples instrumentos da sociedade coletiva medieval, não se tendo desenvolvido em formas sociais definidas. [...] A conta de participação e a comandita, assim, não se 
Assim, o contrato bilateral teria originado a sociedade em comandita. O contrato unilateral, por sua vez, teria originado a sociedade em conta de participação. ${ }^{56}$ Portanto, a sociedade em comandita e a sociedade em conta de participação são provenientes de tronco comum, o contrato de commenda. Com o decorrer dos tempos, as referidas sociedades passaram a ter características próprias que acarretaram uma notória distinção entre os tipos societários, sem perder, contudo, a familiaridade e afinidade entre suas características.

Com efeito, com o passar dos tempos foi possível diferenciar os referidos tipos societários em virtude do fato de que, para as comanditas, passou a ser exigido o registro corporativo e consequente publicidade, o que ensejou a possibilidade de ser demandada por credores. Já a sociedade em conta de participação continuou secreta, sem firma ou razão social própria. ${ }^{57}$

distinguem, para Caroselli, senão no detalhe indicado, surgindo uma e outra na Idade Média como instrumentos da sociedade coletiva." (LOPES, Mauro Brandão. Ensaio sôbre a conta... cit., p. 18).

${ }^{56}$ A este respeito: "Nesse bipartimento, posto em letra de fôrma primeiramente por SILBERSCHMIDT, observou o tratadista italiano, acentuaram-se as preferências dos escritores, "perchè solo dalla comenda bilaterale puó deriváre l'accomandita". Na mesma corrente colocou-se P. de Pelsmaeker. Igualmente se manifestou Cesare Gasca, ao desenvolver a tese de que a rudimentar accomenda da era medieval desenvolveu-se, condindo-se em duas formas distintas: a) a società per via di accomenda, que é a sociedade em comandita; e b) a partecipazione, a que também se dava o nome di accomenda, o accomadigia. Por outro ângulo divisou Levin Goldschmidt o problema. Não encontrou ele, no contingente das fontes históricas, apoios para aquela teoria, embora também esposada por Lastig, mercê da qual a sociedade em comandita e a que se vulgarizou com o nome incolor de participatio, correspondente à stille Gesellschaft do direito tedesco, provinham de raízes diversas, por serem uma e mesma coisa. Não lhe pareceu aceitável, do mesmo modo, a de derivar-se o qualificativo germânico da participação - stille (tácita), da circunstância de não serem os que contribuíam apenas com o capital registrado como sócios nos livros da sociedade.” (FERREIRA, Waldemar. Op. cit., p. 198-199)

${ }^{57}$ A este respeito: "Porque, no antigo direito italiano, como no antigo direito francês, a comandita não se revelava a terceiros. Não agia sob razão social. Por esse motivo, no antigo direito, os comanditários não se expunham à ação direta dos terceiros. Porque ela hoje se apresenta sob forma social é que assiste ação direta dos credores da sociedade contra os comanditários. Como, porém, a participação não deixou de ser o que era outrora; e porque, como antigamente, não tem hoje razão social e as regras, que deixaram de aplicar-se à comandita, continuaram a aplicar-se à participação, disso não é possível concluir pela existência de ação direta contra os participantes, a que, no novo direito, ficaram sujeitos os comanditários". (...) Inexistia ação direta dos credores da sociedade em participação contra os sócios participantes, mercê da inexistência da sociedade, nas relações com terceiros. Mas a recíproca também era verdadeira. Careciam os participantes de ação contra os devedores da sociedade. (...) Diferençaram-se dessarte as duas formas societárias oriundas da comenda, ainda agora subsistentes. Encontra-se na comandita, por efeito de seu registro corporativo, a publicidade de sua organização e funcionamento, verdadeira e autêntica sociedade, a contribuição dos sócios confundida no patrimônio social, que se converteu em penhor comum de todos os seus credores, desde que ela se externou por firma ou razão social, nomine sociali." (FERREIRA, Waldemar. Op. cit., p. 201). 
$\mathrm{SALGADO}^{58}$ menciona que em determinadas cidades da Itália - sua pátria de origem - a sociedade em conta de participação serviu para mitigar os efeitos da responsabilidade ilimitada dos sócios, cumprindo o destino que, em outras cidades da Itália, foi reservado à comandita.

\section{II.2.4 Origem legislativa}

A sociedade em conta de participação possui origem legislativa no Código Francês datado de 1807, no Código Espanhol datado de 1829 e no Código Português datado de 1833.

O Código Português foi o pioneiro em disciplinar, de forma detalhada, a estrutura e a organização da sociedade em conta de participação.

Conforme leciona BRANDÃO LOPES, ${ }^{59}$ o Código Português buscou inspiração na prática do comércio francês, que já adotava a estrutura posteriormente disciplinada pelo Código Português.

Devido aos seus atributos, a sociedade em conta de participação disseminou-se pelos países da Europa, sendo certo que a legislação de determinados países europeus, dentre os quais se destacam a Itália, Espanha e Portugal, influenciaram a legislação brasileira.

\section{II.2.5 A codificação da sociedade em conta de participação no direito brasileiro}

No Brasil, o Código Comercial foi o diploma legal precursor da positivação da sociedade em conta de participação e teve nítida influência dos Códigos Português e Espanhol. ${ }^{60}$

\footnotetext{
${ }^{58}$ SALGADO, Paulo Cavalcanti. Op. cit., p. 37.

${ }^{59}$ LOPES, Mauro Brandão. Ensaio sôbre a conta... cit., p. 14.
} 
O artigo 325 do Código Comercial, revogado, previa que quando duas ou mais pessoas, sendo ao menos uma comerciante, se reúnem, sem firma social, para lucro comum, em uma ou mais operações de comércio determinadas, trabalhando um, alguns ou todos em seu nome individual para o fim social, a associação toma o nome de sociedade em conta de participação, acidental, momentânea ou anônima; esta sociedade não está sujeita às formalidades prescritas para a formação das outras sociedades e pode provar-se por todo o gênero de provas admitidas nos contratos comerciais. ${ }^{61}$

O Decreto n. ${ }^{\circ} 916$, de 24 de outubro de 1890 , em seu artigo $3^{\circ}, \S 4^{\circ}$ previa que "a sociedade em conta de participação não poderá ter firma que indicie a existência de sociedade". 62

O Código Civil de 2002 disciplinou as sociedades em conta de participação no título II, denominado como "Da sociedade", em subtítulo específico denominado como "Da sociedade não personificada".

O Código Civil de 2002 expandiu o regramento das sociedades em conta de participação, já que a disciplinou em 7 (sete) artigos (nos artigos 991 ao 996 e no artigo 1162). O Código Comercial, por sua vez, a disciplinava em apenas 4 (quatro) artigos (do artigo 325 ao 328).

Dentre as inovações legislativas trazidas pelo Código Civil de 2002, é possível destacar: (i) a previsão de que o contrato de sociedade em conta de participação

\footnotetext{
${ }^{60}$ Para elucidar a referida influência do Código Espanhol e do Código Português, vale a pena transcrever os artigo 354 e 571 dos respectivos Códigos. "Artigo 354 do Código Espanhol: Pueden os comerciantes, sin estabelecer companhia formal bajo las reglas que van prescritas, interesarse los unos em las operaciones de los otros, contribuyendo para ellas com la parte de capital que convengan, y haciendose participes de sua resultados prósperos o adversos, bajo la proporción que determinen". E ainda, o artigo 571 do Código Português: "As associações em conta de participação são verdadeiras sociedades mercantis; e podem definir-se as reuniões, que formam dois ou mais comerciantes, sem firma, para lucro comum e social, trabalhando um, alguns ou todos em seu nome individual somente".

${ }^{61}$ Disponível em: <www.planalto.gov.br>. Acesso em: 15 jun. 2012.

${ }^{62}$ Pontes de Miranda critica o referido dispositivo legal sob a alegação de que lhe falta precisão terminológica. Isso porque : "a sociedade em conta de participação não pode ter firma, porque, se a tem, se caracteriza outro tipo; veda-se-lhe o uso de firma para a sociedade, embora exista, não aparece no registro, a respeito os terceiros, pela publicidade registrária. Existe internamente; não se apresenta, lá fora, como pessoa jurídica, nem há as relações jurídicas externas. (...) A sociedade em conta de participação é sociedade, existe no mundo jurídico como sociedade, a despeito de ficar, eficacialmente, oculta." (PONTES DE MIRANDA, Francisco Cavalcanti. Op. cit., p. 320).
} 
só produz efeitos entre os sócios, conforme artigo 993, caput; (ii) a previsão de que o registro não confere personalidade jurídica, conforme artigo 993, caput; (iii) inclusão de parágrafo único ao artigo 993, que prevê que sem prejuízo do direito de fiscalizar a gestão dos negócios sociais, o sócio participante não pode tomar parte nas relações do sócio ostensivo com terceiros, sob pena de responder solidariamente com este pelas obrigações em que intervier; (iv) inserção de regra no sentido de que a contribuição do sócio participante constitui, com a do sócio ostensivo, patrimônio especial, objeto da conta de participação relativa aos negócios sociais, nos termos do artigo 994, caput; (v) inserção de regra, no artigo 995, caput, no sentido de que salvo estipulação em contrário, o sócio ostensivo não pode admitir novo sócio sem o consentimento expresso dos demais; (vi) previsão no sentido de que aplica-se à sociedade em conta de participação, subsidiariamente e no que com ela for compatível, o disposto para a sociedade simples, e a sua liquidação rege-se pelas normas relativas à prestação de contas, na forma da lei processual, nos termos do artigo 996.

Além disso, o Código Civil de 2002 conferiu a designação de "sócio participante" ao sócio que participa da sociedade em conjunto com o sócio ostensivo. O Código Comercial não previa um nome específico para o sócio participante. Em virtude deste fato, a doutrina passou a designá-lo como "sócio oculto". Ocorre que tal fato ensejava a percepção de que a sociedade em conta de participação caracterizava-se como algo escuso, destinado a fraudar a lei e a prejudicar credores e, diante disto, o legislador do Código Civil de 2002 alterou a designação para "sócio participante". 


\section{CAPÍTULO III NATUREZA JURÍDICA, REQUISITOS DE VALIDADE, CONCEITO E PRINCIPAIS CARACTERÍSTICAS DAS SOCIEDADES EM CONTA DE PARTICIPAÇÃO}

\section{III.1 Natureza Jurídica}

O Código Civil de 2002 inovou em diversos aspectos no que se refere à classificação e às características das sociedades em conta de participação.

Dentre as inovações, é importante destacar uma de caráter estrutural, a inserção da disciplina da sociedade em conta de participação em subtítulo próprio das “sociedades não personificadas".

A estrutura do Código Civil de 2002 permite, portanto, corroborarmos três importantes características deste tipo societário: a sua caracterização como "sociedade" "regular" "não personificada", ${ }^{63}$

No entanto, não obstante a previsão legal mencionada acima, a natureza jurídica das sociedades em conta de participação é alvo de debates acirrados e, até os dias atuais, há juristas que defendem que a conta de participação não se caracteriza como verdadeira sociedade. ${ }^{64}$

\footnotetext{
${ }^{63}$ No Código Comercial, a disciplina das sociedades em conta de participação estava prevista no Capítulo próprio das sociedades comerciais.

${ }^{64}$ A este respeito, vide o que leciona João Eunápio Borges: "Se o principal sentido da expressão sociedade é (...) o de pessoa jurídica gerada pelo respectivo contrato, dizer-se que a sociedade em conta de participação não é pessoa jurídica é o mesmo que afirmar-se que ela não é uma sociedade mercantil no genuíno sentido desta expressão. Sobretudo depois que o Código Civil afirmou serem pessoas jurídicas as sociedades mercantis (...) a participação é um simples contrato entre as partes (...). Hoje, porém, fixado não apenas em doutrina mas em nossa lei o conceito da personalidade jurídica das sociedades mercantis, força é excluir a sociedade em conta de participação do número das sociedades propriamente ditas. Embrião de sociedade, sociedade frustra ou larvada, tentativa ou arremedo de sociedade, será ela o que quiser, menos uma verdadeira sociedade." (BORGES, João Eunápio. Curso de direito comercial terrestre. Rio de Janeiro: Forense, 1967, p. 102-103).

A respeito da natureza jurídica das sociedades em conta de participação, é importante mencionar que há, ainda, uma vertente que defende que a conta de participação possui natureza jurídica de associação, no sentido de grupo organizado sem personalidade jurídica, como há no direito italiano. Segundo esses autores, não se forma um fundo social ou patrimônio especial porque todos os recursos entregues pelo sócio oculto acrescem ao patrimônio do sócio-gerente. A falta deste patrimônio ou fundo comum faz com que se conteste a natureza de sociedade da conta de participação. A respeito desse tema, vide o que leciona a Professora Rachel Sztajn: "Tal afirmação não pode ser aceita em face das disposições do nosso direito. Em primeiro lugar, porque o art. 1363 do Código Civil, quando define o contrato de sociedade,
} 
Essa discussão é atual. O jurista ULHOA COELHO, ${ }^{65}$ por exemplo, defende a tese de que as sociedades em conta de participação deveriam, na verdade, ser consideradas uma espécie de contrato de investimento. E mais, o Projeto de Lei n. ${ }^{\circ}$ 1.572, de 2011, de autoria de Vicente Candido e coordenado por Fabio Ulhoa Coelho, que pretende instituir um novo Código Comercial, classifica a sociedade em conta de participação como contrato de investimento conjunto.

Da mesma forma, a conta de participação não é verdadeira sociedade para TAVARES BORBA, ${ }^{66}$ TOMAZETTE $^{67}$ e GONÇALVES NETO ${ }^{68}$ Para defender sua tese, os referidos juristas mencionam que a sociedade em conta de participação não é uma verdadeira sociedade pelo fato de não constituir um sujeito autônomo de direitos e obrigações. Por tal razão, a conta de participação se caracterizaria como um simples contrato de participação, no qual o sócio ostensivo obriga-se a agir como ajustado com as demais partes.

Defensores da tese de que as sociedades em conta de participação não se caracterizam como verdadeira sociedade utilizam, dentre seus argumentos, o fato de que na vigência do Código Civil de 1916, as sociedades regulares possuíam contrato inscrito em órgãos de registro do comércio e, com isso, adquiriam personalidade jurídica. As sociedades irregulares, por outro lado, não possuíam contrato escrito e, com isso, não era possível seu registro no órgão de registro do comércio e consequente atribuição de personalidade jurídica.

\footnotetext{
não distingue sociedade e associação como fez o legislador italiano; em segundo lugar porque nem o legislador de 1850 exigia a constituição de um patrimônio social especial (como também não faz essa exigência o Código Civil), mas, principalmente, por classificar a conta de participação entre as sociedades comerciais." (SZTAJN, Rachel. Contrato de sociedade... cit., p. 70).

${ }^{65}$ A este respeito, vide: "Tais, de qualquer forma, são as peculiaridades deste tipo societário, que seria preferível entendê-lo, mais, como uma espécie de contrato de investimento, que o legislador resolveu denominar por "sociedade", do que, propriamente, como uma espécie de sociedade comercial." (ULHOA COELHO, Fabio. Manual de direito comercial. 20. ed. São Paulo: Saraiva. 2008. p. 152)

${ }^{66}$ BORBA, José Edwaldo Tavares. Direito Societário. 11. ed. rev. aum. e atual. Rio de Janeiro: Renovar, 2008. p. 105-107.

${ }^{67}$ TOMAZETTE, Marlon. Curso de direito empresarial. v. 1. São Paulo: Atlas, 2008. p. 282.

${ }^{68}$ GONÇALVES NETO, Alfredo de Assis. Lições de direito societário: regime vigente e inovações do novo Código Civil. São Paulo: Juarez de Oliveira, 2002. p. 153.
} 
Com base nisto, tais juristas, dentre os quais se destaca EUNÁPIO BORGES, ${ }^{69}$ defendiam que as sociedades em conta de participação não eram caracterizadas como sociedade, já que não possuíam todos os requisitos necessários para a formação de uma sociedade regular, dentre os quais se destacam a personalidade jurídica e o registro de seus atos constitutivos no órgão competente.

Assim, os defensores de que a sociedade em conta de participação não pode ser considerada como verdadeira sociedade utilizam o argumento de que somente é possível se formar contrato plurilateral mediante a conjunção de indivíduos em uma sociedade com personalidade jurídica e patrimônio próprio. ${ }^{70}$

Não obstante as divergências apontadas acima, a posição doutrinária dominante é no sentido de que a conta de participação caracteriza-se como sociedade.

Nos termos do caput do artigo 981 do Código Civil de 2002, celebram contrato de sociedade as pessoas que reciprocamente se obrigam a contribuir, com bens

\footnotetext{
${ }^{69}$ BORGES, João Eunápio. Op. cit., p. 102-103.

${ }^{70}$ Neste sentido, vide trecho de Tullio Ascarelli "A chamada sociedade ou associação em conta de participação constitui um contrato bilateral; de permuta ou escambo no amplo significado deste termo, adotado nestas páginas; dominus do negócio é, sempre e necessariamente, o associante que, somente ele, assume obrigações e adquire direitos para com os terceiros, ao passo que os associados são responsáveis somente perante o associante e têm direitos somente perante ele; não se cria uma nova organização, nem externa - essa é a diferença invocada com a maior frequência - nem interna; até quando o associante admite mais pessoas a participar de seus negócios, isso tem lugar através de outros tantos contratos bilaterais distintos.

Na sociedade, ao contrário, achamo-nos em presença de uma nova organização: nenhum dos sócios pode dizer-se, juridicamente, dominus do negócio; se a organização entra em relações com terceiros, é a todos os sócios, coletivamente, que se referem tais relações; se isso não acontece, as relações com terceiros são, individualmente, assumidas por cada sócio por sua conta.” (ASCARELLI, Tullio. Problemas das sociedades anônimas e direito comparado. 2. ed. São Paulo: Saraiva, 1969).

Em sentido contrário, vide excerto do Professor Fabio Konder Comparato: "Elemento essencial dos contratos ditos plurilaterais, em contraste com os de intercâmbio, não é apenas o aspecto exterior de aqueles poderem, e este não, contar com mais de duas partes. É também a comunhão de objeto e objetivo, própria dos contratos plurilaterais. A comunhão de objeto diz respeito à atividade a ser desenvolvida no quadro do contrato, que assume, sob este aspecto, um caráter nitidamente instrumental. A segunda incide sobre o escopo ou finalidade do exercício dessa mesma atividade. (...) A atividade é comum, não necessariamente no sentido de que todos os sócios deverão exercitá-la diretamente, mas porque ela é supostamente exercida em benefício de todos os sócios, e não de alguns deles apenas." (COMPARATO, Fabio Konder. $O$ direito ao lucro nos contratos sociais. Direito Empresarial - Estudos e Pareceres. São Paulo: Saraiva, 1990. p. 150).

Diante disso, é possível afirmar que os sócios, ao contratarem a sociedade em conta de participação, possuem comunhão de objetivos aptos a caracterizar os contratos plurilaterais. Não obstante o fato de que o sócio participante não assume obrigações perante terceiros, é certo que as atividades sociais o beneficiam via distribuição de lucros e/ou partilha de resultados.
} 
ou serviços, para o exercício de atividade econômica e a partilha, entre si, dos resultados.

Tendo em vista que os sócios - ostensivos e participantes - contribuem para a formação do fundo social que constitui patrimônio especial e também participam dos resultados alcançados pela sociedade mediante recebimento de lucros, se existentes, entendemos que a estrutura da sociedade em conta de participação se enquadra no conceito do caput do artigo 981 do Código Civil de $2002^{71}$ e, assim, é verdadeira sociedade.

A sociedade em conta de participação pode ser caracterizada como sociedade interna, já que o sócio ostensivo contrata com terceiros em seu nome pessoal e, portanto, a comunhão de objetivos ocorre no âmbito interno da sociedade, mediante a comunhão de bens ou serviços para o exercício da atividade econômica e a partilha de resultados.

A personalidade jurídica não é requisito essencial para a existência de sociedades. $^{72}$

É importante esclarecer que a sociedade em conta de participação é uma sociedade regular, apesar da ausência de personalidade jurídica. Esse esclarecimento

\footnotetext{
${ }^{71}$ O caput do artigo 981 do Código Civil de 2002 prevê: "Celebram contrato de sociedade as pessoas que reciprocamente se obrigam a contribuir, com bens ou serviços, para o exercício de atividade econômica e a partilha, entre si, dos resultados". E, ainda, o seu parágrafo único prevê que: "A atividade pode restringir-se à realização de um ou mais negócios determinados".

${ }^{72}$ Neste sentido, vide: BARRETO FILHO, Oscar. Regime jurídico das sociedades de investimentos. São Paulo: Max Limonad, 1956. LOPES, Mauro Brandão. A sociedade em conta de participação. São Paulo: Editora Saraiva, 1990. p. 26. WALD, Arnoldo. In: TEIXEIRA, Sálvio de Figueiredo (Coord.). Comentários ao novo Código Civil. Do direito da empresa. Livro 2, v. 14. Rio de Janeiro: Forense, 2005, p. 99-100.

A conta de participação é tida como verdadeira sociedade na grande maioria das legislações estrangeiras. Mauro Brandão Lopes leciona que na França, o artigo 49 do Código Comercial, na redação que lhe deu a lei de 24 de junho de 1921, caracteriza a conta de participação como verdadeira sociedade. Da mesma forma, a Alemanha também conceitua a conta de participação como sociedade sob a denominação de "stille Gesellschaft". Na Itália, apesar de ser tratada no Código Civil de 1942 em título separado, sob a denominação de "associação", em contraposição às sociedades do título anterior, a conta de participação apresenta todas as três características da sociedade e a maioria dos juristas defendem a sua conceituação como verdadeira sociedade. Em Portugal, embora o legislador de 1888, ao contrário do de 1833, tenha omitido a expressão "associação", é patente o caráter associativo do instituto, ao falar o Código do Comércio, no seu artigo 224, que, na conta de participação, "o comerciante interessa uma ou mais pessoas ou sociedades nos seus ganhos e perdas". (LOPES, Mauro Brandão. Ensaio sôbre a conta... cit.)
} 
possui sobremaneira relevância, uma vez que a única outra sociedade prevista na legislação pátria que não possui personalidade jurídica é a sociedade em comum.

A sociedade em conta de participação é uma sociedade regular pelo fato de estar submetida à disciplina própria das sociedades regulares. $\mathrm{O}$ fato é que as sociedades regulares se dividem entre as que possuem personalidade jurídica e uma sociedade sem personalidade jurídica, a sociedade em conta de participação.

A distinção dentre a sociedade regular em conta de participação e a sociedade irregular está evidenciada nos diferentes regimes legais a que se submetem.

Uma vez que foi demonstrado acima que as sociedades em conta de participação são verdadeiras sociedades regulares, cumpre-nos afirmar que o referido tipo societário não tem personalidade jurídica. ${ }^{73}$

A personalidade jurídica é desenvolvimento recente.

O Código Comercial começou a delinear os seus contornos, ainda que de forma não expressa, em paralelo a discussões doutrinárias a respeito do tema.

O Código Civil de 1916, em seu artigo 16, foi o diploma legal que admitiu a existência de personalidade jurídica ao afirmar que as sociedades mercantis são "pessoas jurídicas de direito privado".

A Conferência do Direito Internacional Privado realizada em Haia, em 1951, fixou as seguintes condições essenciais para o reconhecimento da personalidade

\footnotetext{
${ }^{73}$ No sentido de não atribuir personalidade jurídica a determinados entes, nos parece que o legislador alemão previu disciplina semelhante no § 54 do BGB, que prevê os nichtrechtsfähige Vereine. De acordo com J. Lamartine Corrêa de Oliveira "o legislador pretendeu submeter basicamente às normas jurídicas pertinentes à sociedade civil uma entidade, o Verein (corporação), que, apesar de não ter cumprido formalidade do registro (não obtendo portanto a personalidade jurídica conforme o $§ 21$ do BGB: associações de finalidades não econômicas) ou de não ter obtido a concessão da personalidade (associações econômicas: $\S 22$ do BGB) aproxima-se, por sua inteira estrutura, muito mais de uma associação regular que de uma sociedade civil. Com efeito, nesta última, estamos diante de uma reunião de pessoas em que a separação entre sócio e sociedade não é tão clara e nítida, enquanto que no Verein, regular ou irregular, a busca das finalidades da corporação é basicamente independente da personalidade dos associados. (OLIVEIRA, José Lamartine Corrêa de. A dupla crise da personalidade jurídica. São Paulo: Saraiva, 1979. p. 105-106).
} 
de sociedades: capacidade judicial, ativa e passiva; capacidade de possuir bens; capacidade de celebrar contratos e praticar atos jurídicos em geral.

Conforme SZTAJN, ${ }^{74}$ o reconhecimento da personalidade jurídica produz a concentração da totalidade das relações plúrimas e complexo de associados ou órgãos em um ente jurídico novo e os direitos e responsabilidades passam para o novo ente. Concentram-se neste sujeito ideal os direitos, os poderes e as responsabilidades.

Em momento anterior a tal desenvolvimento, as sociedades regulares existiram explicitamente regulamentadas e, portanto, com pleno reconhecimento na ordem jurídica, exatamente como subsistem em muitas legislações.

Firmado este ponto, teríamos como verdadeiras sociedades, no consenso quase unânime da doutrina e da jurisprudência, não somente as sociedades irregulares do direito brasileiro e de outros, mas também as sociedades regulares não personalizadas de inúmeras legislações, dentre as quais se inclui a sociedade em conta de participação. $^{75}$

Para os fins deste estudo, também é importante abordar o tema da tipicidade. $^{76}$

\footnotetext{
${ }^{74}$ SZTAJN, Rachel. Sobre a desconsideração da personalidade jurídica. Revista dos Tribunais, ano 88, v. 762, São Paulo, RT, 1988, p. 81-97.

${ }^{75}$ Mauro Brandão Lopes menciona que o estudo do direito comparado autoriza a afirmação de que existem sociedades regulares sem personalidade jurídica. No direito alemão, por exemplo, as sociedades de capitais possuem personalidade jurídica, enquanto as sociedades de pessoas não possuem. No direito inglês, as companhias possuem personalidade jurídica e são, portanto, consideradas titulares dos bens que adquirem. (...) Além delas, todavia, o direito inglês regula sociedades de pessoas, que não tem personalidade jurídica, são as denominadas "Partnership firms". (...) Quanto aos sistemas mais próximos do nosso, embora o francês considere todas as sociedades como pessoas jurídicas, o italiano não reconhece a todas tal personalidade.

E ainda: "Com o exame desses sistemas - o alemão, o inglês, o americano e o italiano - fica estabelecido o fato de que à figura jurídica da sociedade não é essencial a personalidade.

A personalidade jurídica é desenvolvimento recente; anteriormente a tal desenvolvimento, as sociedades regulares existiram explicitamente regulamentadas e, portanto, com pleno reconhecimento na ordem jurídica, exatamente como subsistem ainda em muitas legislações; e, posteriormente ao mesmo desenvolvimento, as sociedades irregulares de muitos países continuam a produzir efeitos jurídicos, fugindo embora à pressão legal para se regularizarem. Firmado este ponto, teríamos como verdadeiras sociedades, no consenso quase unânime da doutrina e da jurisprudência, não somente as sociedades irregulares do direito brasileiro e de outros, mas também as sociedades regulares não personalizadas de inúmeras legislações." (LOPES, Mauro Brandão. Ensaio sôbre a conta... cit., p. 34-49 e 48-49).

${ }^{76}$ A este respeito, a Professora Juliana Krueger Pela leciona que: "Ao direito societário aplica-se o princípio da tipicidade fechada, ou para utilizar a nomenclatura aqui proposta, a tipicidade de origem legal. (...) Segundo esse raciocínio, caso os agentes econômicos pretendam atuar cooperativamente para a
} 
A sociedade em conta de participação é uma sociedade típica no direito brasileiro. Isso porque os artigos 991 a 996 do Código Civil de 2002 preveem a sua existência e disciplinam as suas principais características.

O artigo 983 do Código Civil de 2002 prevê que a sociedade empresária deve constituir-se segundo um dos tipos regulados nos artigos 1.039 a 1.092; a sociedade simples pode constituir-se de conformidade com um desses tipos, e, não o fazendo, subordina-se às normas que lhe são próprias. ${ }^{77}$

O parágrafo único do referido artigo prevê, ainda, exceções à regra prevista acima ao ressalvar as disposições concernentes à sociedade em conta de participação e à cooperativa, bem como as constantes de leis especiais que, para o exercício de certas atividades, imponham a constituição da sociedade segundo determinado tipo. ${ }^{78}$

Entendemos que o caput do artigo 983 do Código Civil de 2002 tem a intenção de elencar os tipos societários previstos no referido diploma legal. O parágrafo único do referido artigo menciona as sociedades em conta de participação pelo fato desta sociedade constituir um tipo previsto no referido diploma legal, mas não estar regulada nos artigos 1.039 a 1.092, mas sim em outros dispositivos legais próprios.

\footnotetext{
consecução de um objetivo comum e intentem, para tanto, constituir sociedade, devem necessariamente valer-se de um dos tipos previstos na ordem jurídica. Consequentemente, ser-lhes-á vedado, no exercício da autonomia privada, criar estruturas societárias atípicas. Tal vedação, embora sofra críticas, não é desprovida de fundamento. Com efeito, as sociedades constituem, sob o ponto de vista econômico, verdadeiros veículos para a mais eficiente alocação de bens no mercado e, como tais, postam-se como vértice de reiteradas e diversas relações jurídicas com outros agentes de mercado que não conhecem e não têm o ônus de conhecer eventuais arranjos atípicos que os sócios tenham decidido inserir no contrato ou estatuto social. Neste sentido, a definição de tipos em matéria societária buscaria, a um só tempo, assegurar a organização e o controle sobre a alocação de recursos no mercado - à semelhança do que ocorrer com os direitos reais, por exemplo - e tutelar os terceiros que contratam com a sociedade, a quem com isso se dá a oportunidade de conhecer, desde logo, o regime da responsabilidade dos sócios. Esse último elemento, o regime da responsabilidade dos sócios pela obrigações sociais, mostra-se tão central à disciplina das sociedades que costuma inclusive ser apontado pela doutrina como o principal critério de identificação dos tipos societários. (PELA, Juliana Krueger. As golden shares no Direito Brasileiro. São Paulo: Quartier Latin, 2012. p. 108-109).

${ }^{77}$ Disponível em: <www.planalto.gov.br>. Acesso em: 20 set. 2013.

${ }^{78}$ Disponível em: <www.planalto.gov.br>. Acesso em: 20 set. 2013.
} 


\section{III.2 Requisitos de validade do instrumento de constituição da sociedade em conta de participação}

Antes de adentrar no tema deste Capítulo, mister esclarecer a distinção entre existência, validade e eficácia. ${ }^{79}$

Para que um fato jurídico exista - dentre o que se inclui o negócio jurídico é necessária a vigência de norma legal a este respeito e que quando prevista na norma legal seja verificada no mundo real.

Para que um fato jurídico seja válido é necessário que ele cumpra os requisitos determinados pela lei.

Para que um fato jurídico seja eficaz é preciso que produza efeitos jurídicos.

Portanto, no caso das sociedades em conta de participação, é evidente que o Código Civil de 2002, ao disciplinar o tipo societário em seus artigos 991 a 996, faz com que o tipo societário exista no mundo do direito. Assim, as pessoas, nos casos concretos, devem partir deste pressuposto e formalizar sua vontade de fazer com que a sociedade em conta de participação exista no mundo real para formalizar uma relação jurídica.

No presente item abordar-se-ão os requisitos necessários para que os contratos que formalizam a constituição das sociedades em conta de participação sejam válidos.

Já no campo da eficácia, há um importante esclarecimento a ser feito. Tratase da distinção da eficácia dos contratos de constituição de sociedade em conta de participação perante terceiros e a eficácia entre os sócios.

\footnotetext{
${ }^{79}$ Para tanto, partimos dos conceitos trazidos por Antônio Junqueira de Azevedo (AZEVEDO, Antonio Junqueira de. Negócio jurídico: existência, validade e eficácia. 4. ed. atual. de acordo com o novo Código Civil ( Lei n. 10.406, de 10-1-2002). São Paulo: Saraiva, 2002)
} 
Entre os sócios a eficácia é completa: a sociedade existe, pode ser válida e é eficaz. No tocante aos terceiros, a sociedade existe, pode ser válida, mas os seus efeitos não alcançam terceiros.

Feito este esclarecimento a respeito da eficácia, os pontos abaixo abordarão de forma mais pormenorizada os requisitos de validade das sociedades em conta de participação.

Uma vez verificada que a conta de participação caracteriza-se como verdadeira sociedade interna, regular e sem personalidade jurídica, é importante fixar que, como todo contrato em sentido estrito e como contrato de sociedade, a constituição das sociedades em conta de participação deve observar determinados requisitos de validade.

Dentre tais requisitos, destacam-se: (i) os sócios devem ser agentes capazes; (ii) o objeto e a finalidade das sociedades em conta de participação devem ser lícitos, possíveis e determinados; (iii) os critérios referentes à forma de constituição da sociedade em conta de participação devem ser observados.

A respeito do primeiro requisito - agentes capazes - há discussões acerca da eventual possibilidade de um agente incapaz participar como sócio participante de sociedades em conta de participação.

A principal discussão diz respeito às hipóteses em que não há pacto de divisão de prejuízos entre os sócios ostensivos e os sócios participantes. Neste caso, há quem defenda que seria possível que o incapaz participasse como sócio participante, desde que, obviamente, seja devidamente assistido ou representado.

Isto porque, no caso aventado acima, a responsabilidade do sócio participante seria limitada e, então, seria possível equiparar a situação às hipóteses em que incapazes são sócios de sociedades limitadas ou de sociedades anônimas. A possibilidade de participação de agentes incapazes como sócios de sociedades limitadas ou de sociedades anônimas já é admitida pela doutrina e jurisprudência pátria e o principal argumento que baliza este entendimento diz respeito ao fato de que a 
responsabilidade limitada enseja a preservação do patrimônio pessoal dos sócios incapazes por dívidas da sociedade.

Há determinados autores, dentre os quais se filia PONTES DE MIRANDA, ${ }^{80}$ que entendem que os sócios ostensivos e os sócios participantes têm de ser capazes, no plano do direito civil, ou no plano do direito comercial, conforme a espécie. A diferença seria no sentido de que os requisitos para exercer o comércio só se seriam exigidos dos sócios ostensivos.

Outra discussão relevante acerca do tema reside na eventual possibilidade de um agente impedido por lei de exercer atividade empresarial integrar uma sociedade em conta de participação como sócio participante.

Há quem defenda que, nesta hipótese, o raciocínio aplicado aos investimentos em ações de sociedades anônimas ou em quotas de sociedades limitadas deve servir como base para sustentar que não há óbice na referida participação. ${ }^{81}$

Não obstante o exposto acima, entendemos que não há discussão acerca da impossibilidade de um agente incapaz figurar como sócio ostensivo em uma sociedade em conta de participação. $\mathrm{O}$ fato de que as atividades sociais são exercidas em nome do sócio ostensivo faz com que este deva gozar de plena capacidade civil. Além disso, a pessoa física ou jurídica que figurar como sócio ostensivo não pode estar legalmente impedido de exercer tal posição jurídica. ${ }^{82}$

Ressalta-se, ainda, que tanto as pessoas físicas quanto as pessoas jurídicas podem figurar como sócias ostensivas e participantes de sociedades em conta de

\footnotetext{
${ }^{80}$ PONTES DE MIRANDA, Francisco Cavalcanti. Op. cit., p. 339.

${ }^{81}$ Neste sentido, SCALZILLI, João Pedro; SPINELLI, Luis Felipe. Reflexões sobre a sociedade em conta de participação no direito brasileiro. Revista Jurídica Empresarial, ano 3, jan./fev. 2010, n. ${ }^{\circ}$ 12, p. 3640. Para referidos autores, a afirmação acima não pode ser levada a extremos, havendo, sim, situações que devem ser analisadas cum granus salis, a fim de se reconhecer uma eventual finalidade fraudulenta no negócio, como, por exemplo, uma sociedade em conta de participação constituída entre um sócio ostensivo e um magistrado, por hipótese, cumprindo cargo administrativo de um Tribunal, que, por sua vez, contrata os serviços do sócio ostensivo daquela referida sociedade em conta de participação.

${ }^{82}$ Por esta razão, os funcionários públicos, por exemplo, não poderiam figurar como sócio ostensivo de sociedades em conta de participação. Da mesma forma, as sociedades brasileiras que optaram pelo regime de lucro presumido não podem participar como sócia ostensiva de sociedades em conta de participação que possuam participação societária em sociedades estrangeiras.
} 
participação. Contudo, a atuação da pessoa jurídica, seja como sócia ostensiva ou como sócia participante, deve sempre ser condizente com o seu objeto social, que deverá conter de forma expressa, mediante previsão no contrato ou estatuto social, que a atividade social inclui a participação em outras sociedades.

Quanto ao segundo requisito - objeto lícito - o artigo 104, inciso II, do Código Civil de 2002 prevê que a validade do negócio jurídico requer objeto lícito, possível, determinado ou determinável.

Desta forma, sempre que o objeto de uma sociedade em conta de participação consistir em atividade impossível ou ilícita, qualquer prejudicado poderá requerer a nulidade dos atos constitutivos da sociedade em conta de participação. ${ }^{83}$

Ademais, o objeto social deve ser determinado ou determinável, como ocorre com o objeto social de qualquer sociedade.

Por fim, é importante mencionar que a natureza da atividade explorada pelo sócio ostensivo determinará se a sociedade em conta de participação será empresária ou não empresária. ${ }^{84}$ Portanto, a sociedade em conta de participação poderá exercer qualquer atividade lícita, empresária ou não empresária. A caracterização de uma sociedade em conta de participação como empresária ou não empresária será

\footnotetext{
${ }^{83}$ Conforme Pontes de Miranda: "O objeto da atividade, de cujos lucros e perdas se participa, tem de ser lícito. Se não o é, há nulidade. Dá-se o mesmo se impossível o objeto. Se a sociedade se propõe a operações que ficaram limitadas por lei às bolsas, aos bancos ou a outras empresas, o objeto é lícito (PONTES DE MIRANDA, Francisco Cavalcanti. Op. cit., p. 339). A este respeito, José Reinaldo de Lima Lopes entende que: "A sociedade em conta de participação não pode ter objeto ilícito, logo não poderia servir para ocultar atividade ilícita. Se assim fosse, o negócio estaria fulminado não de anulabilidade, mas de ineficácia, isto é, invalidade. Invalidade significa inexistência jurídica. O negócio não adquire força para produzir efeitos jurídicos, ou melhor, para produzir os efeitos jurídicos para os quais foi realizado. Como se sabe, a invalidade ou ineficácia do ato jurídico não é uma sanção. Significa apenas que tal ato jurídico não tem existência jurídica. A sanção pode vir a ser aplicada aos sujeitos que praticavam tal ato na medida em que o mesmo, além de não adquirir validade jurídica, constituir um delito ou ilícito. Vale dizer, pode ocorrer, que a determinado ato a lei não só não reconheça força para produzir efeitos jurídicos (ineficácia), como também repute condição para aplicar sanção (ilicitude). Os dois elementos podem estar juntos ou não. E podem ter esferas de consequências separadas. (LOPES, José Reinaldo Lima. Negócio fiduciário, comunhão de interesses e sociedade em conta de participação. Jornal O Estado de São Paulo. Edição de 13 de junho de 1987). E, ainda, vale mencionar João Manoel Carlos de Gusmão (GUSMÃO, João Manoel Carlos de. Operações em conta de participação assumem o caracter de verdadeira sociedade? quaes os elementos caracteristicos das operações em conta de participação? Theses e Dissertação apresentadas A' Faculdade de Direito de São Paulo para o concurso que deve ter lugar em Junho de 1882. São Paulo: 1882, p. 15-16).

${ }^{84}$ GONÇALVES NETO, Alfredo de Assis. Direito de empresa: comentários aos artigos 966 a 1195 do Código Civil. 2. ed. rev. atual. e ampl. São Paulo: RT, 2008. p. 150.
} 
determinada pela característica das atividades exercidas pelo sócio ostensivo, sendo certo que, se o sócio ostensivo for pessoa jurídica, as atividades desenvolvidas pela sociedade em conta de participação devem estar previstas dentre as atividades de seu objeto social.

Quanto ao terceiro requisito, que está previsto no artigo 104, inciso III, do Código Civil de 2002, a validade dos negócios jurídicos requer a forma prescrita ou não defesa em lei.

A infração de regra jurídica sobre forma somente ocorre se, in casu, a lei especial a exige. ${ }^{85}$

O artigo 992 do Código Civil de 2002, por sua vez, prevê que a constituição da sociedade em conta de participação independe de qualquer formalidade e pode provar-se por todos os meios de direito. ${ }^{86}$

Portanto, no caso das sociedades em conta de participação, a legislação aplicável não exige uma forma específica ou pré-definida. No entanto, recomenda-se a elaboração dos atos constitutivos sob a forma escrita. A recomendação é válida para que se fixem os direitos e obrigações recíprocas.

$\mathrm{O}$ ato constitutivo da sociedade em conta de participação não depende de registro em órgãos de registro do comércio, em cartórios de registro de pessoas jurídicas e/ou em cartórios de registro de títulos e documentos.

O eventual registro, a critério dos sócios, não ensejará a produção de efeitos perante terceiros.

\section{III.3 Conceito da Sociedade em Conta de Participação}

A respeito do conceito da sociedade em conta de participação, vide excerto de WALDEMAR FERREIRA: ${ }^{87}$

\footnotetext{
${ }^{85}$ Conforme Pontes de Miranda. PONTES DE MIRANDA, Francisco Cavalcanti. Op. cit., p. 339.

${ }^{86}$ Disponível em: <www.planalto.gov.br>. Acesso em: 23 set. 2013.
} 
Mais prático do que jurisconsulto, na opinião de G. MASSÉ, mas redator principal da Ordenança de 1673, JACQUES SAVARY, mas hábil no descrever do que no definir, descreveu a participação no seu tempo chamada - sociedade anônima, em termos dignos de nota.

Ela assim se chama, por não ter nome. Não é conhecida de ninguém, por não importar ao público de maneira alguma. Tudo quanto se faz no negócio, tanto em compra, quanto em venda de mercadorias, não se refere senão aos sócios, chacun en droit soi. De tal jeito, o sócio, que compra, é o que se obriga e paga ao vendedor: o que vende, recebe do comprador. Êles não se obrigam senão um, o que agiu, como único obrigado: eles, porém, se obrigam reciprocamente, um para com o outro, no concernente a esta sociedade. Algumas são verbais, outras por escrito, mas a maior parte se faz por cartas missivas, que os comerciantes escrevem um aos outros.

Não se satisfez o velho jurisconsulto em descrever. Exemplificou. Navio, eis um dos exemplos, vindo de Esmirna, chega ao pôrto de Marselha. Negociante marselhês, conhecedor do carregamento, propõe a comerciante parisiense participar, com êle, na compra e na venda de todo ou parte do carregamento, determinando a que tomem para si. Aceita a proposta, entre êles se estabelece sociedade participe ou Anônima, por via da qual o de Marselha compra o carregamento, revende-o pelo melhor preço e presta contas da operação ao de Paris, ao qual entrega, na proporção convencionada, os lucros obtidos, ou lhe dá notícia das perdas verificadas. Era o que, no dizer de SAVRY, se chamava um compte em participation.

Conforme exposto no Capítulo II, na época da citação de Jacques Savary, referida acima, a sociedade em conta de participação ainda não era vista como verdadeira sociedade.

Com o decorrer do tempo, a conta de participação passou a ser caracterizada como sociedade sem personalidade jurídica, na qual as atividades constitutivas do objeto social são exercidas unicamente pelo sócio ostensivo, em seu nome individual e sob sua própria responsabilidade, participando os demais dos resultados correspondentes.

Deste fato, decorrem determinadas características típicas das sociedades em conta de participação, que passarão a ser expostas e analisadas nos itens subsequentes deste Capítulo.

\footnotetext{
${ }^{87}$ FERREIRA, Waldemar. Op. cit., p. 202.
} 
Neste contexto, já com o advento da caracterização da conta em participação como verdadeira sociedade, o artigo 325 do Código Comercial, já revogado, a definia da seguinte forma: ${ }^{88}$

\begin{abstract}
Quando duas ou mais pessoas, sendo ao menos uma comerciante, se reúnem, sem firma social, para lucro comum, em uma ou mais operações de comércio determinadas, trabalhando um, alguns ou todos, em seu nome individual para o fim social, a associação toma o nome de sociedade em conta de participação, acidental, momentânea ou anônima; esta sociedade não está sujeita às formalidades prescritas para a formação das outras sociedades, e pode provar-se por todo o gênero de provas admitidas nos contratos comerciais.
\end{abstract}

O Código Civil de 2002 alterou de forma significativa a disciplina jurídica da sociedade em conta de participação ao revogar o artigo 325 do Código Comercial.

O diploma legal citado acima não define o conceito de sociedade em conta de participação, mas prevê, em seu artigo 991 que $^{89}$ :

Na sociedade em conta de participação, a atividade constitutiva do objeto social é exercida unicamente pelo sócio ostensivo, em seu nome individual e sob sua própria e exclusiva responsabilidade, participando os demais dos resultados correspondentes.

Por sua vez, o parágrafo único do mesmo artigo dispõe que: "Obriga-se perante terceiros tão-somente o sócio ostensivo; e, exclusivamente perante este, o sócio participante, nos termos do contrato social."

Diante do exposto, pode-se afirmar que a estrutura da sociedade em conta de participação é formada por dois tipos sócios, o sócio ostensivo e o sócio participante. A atividade da sociedade é desenvolvida apenas pelo sócio ostensivo, em seu nome e sob sua exclusiva responsabilidade. Os sócios participantes contribuem para a formação do fundo social e, em decorrência deste fato, participam dos resultados correspondentes.

A sociedade em conta de participação é uma sociedade ad intra, visto que, nos termos do artigo 993 do Código Civil de 2002, produz efeito somente entre os sócios e, portanto, não aparece juridicamente aos olhos do público..$^{90}$

\footnotetext{
${ }^{88}$ Disponível em: <www.planalto.gov.br>. Acesso em: 20 set. 2013.

${ }^{89}$ Disponível em: <www.planalto.gov.br>. Acesso em: 20 set. 2013.
} 
As relações jurídicas com terceiros são formalizadas por meio da figura do sócio ostensivo, que se obriga pessoalmente, em seu próprio nome, mesmo que o terceiro contratante tenha pleno conhecimento da existência da sociedade.

O sócio ostensivo atua perante terceiros de forma a responsabilizar os fundos sociais. A respeito dos fundos sociais, é importante mencionar que são formados por bens que, ainda que conferidos pelo sócio participante, integrarão o patrimônio do sócio ostensivo. ${ }^{91}$

No entanto, o artigo 994 do Código Civil de 2002 admite a existência de um patrimônio especial, que somente produz efeitos em relação aos sócios, conforme previsto no parágrafo primeiro do mencionado dispositivo legal.

A ausência de personalidade jurídica e, por consequência, a ausência de capacidade jurídica e autonomia patrimonial ensejam outras importantes características da sociedade em conta de participação, que passarão a ser expostas e analisadas nos itens subsequentes.

\section{III.4 Principais características da sociedade em conta de participação}

Conforme exposto acima, a caracterização da conta de participação como verdadeira sociedade sem personalidade jurídica enseja uma série de características próprias deste tipo societário.

Os itens III.4.1 a III.4.8 procurarão abordar e analisar as referidas características.

\footnotetext{
${ }^{90}$ Para fins tributários, a sociedade em conta de participação é equiparada à pessoa jurídica, conforme previsto no artigo 148 do Decreto n. ${ }^{\circ} 3.000$, de 26 de março de 1999 - Regulamento do Imposto sobre a Renda e Proventos de Qualquer Natureza.

${ }^{91}$ A este respeito, vide o Capítulo IV.
} 


\section{III.4.1 Impossibilidade de assumir obrigações e ser titular de direitos}

A sociedade em conta de participação não é apta a assumir direitos e contrair obrigações e também não é apta a assumir deveres e responsabilidades. Estes fatos advêm da ausência de personalidade jurídica deste tipo societário, tema já analisado neste Capítulo.

Em virtude deste fato, a sociedade não pode, por si própria, assumir posições ativas e passivas e adquirir direitos e contrair obrigações. Estas tarefas são exercidas pelo sócio ostensivo, que as fazem em nome próprio.

\section{III.4.2 Impossibilidade de ser parte em processo administrativo e judicial}

Também como consequência da ausência de personalidade jurídica e da impossibilidade de contrair obrigações e assumir direitos em nome próprio, a sociedade em conta de participação não pode demandar e ser demandada em juízo.

O artigo $7^{\circ}$ da Lei n. ${ }^{\circ}$ 5.869, de 11 de janeiro de 1973 (Código de Processo Civil) prevê que toda pessoa que se acha no exercício dos seus direitos tem capacidade para estar em juízo. Ocorre que a posição ativa ou passiva em juízo nas sociedades em conta de participação cabe ao sócio ostensivo. Isto porque, ao contrair as obrigações em seu próprio nome, o sócio ostensivo assume os deveres e responsabilidades daí decorrentes, o que faz com que eventuais demandas devam ser ajuizadas em seu nome. $^{92}$

\footnotetext{
${ }^{92}$ Neste sentido, o Superior Tribunal de Justiça já se manifestou de modo expresso: "Sociedade em Conta de Participação. Embargos de Declaração. Dissolução. Nomeação de Liquidante. Citação da Sociedade Constituída. Indenização. 1. (...). 2. Não há de se falar em citação da sociedade em conta de participação, que não tem personalidade jurídica, nem existência perante terceiros." (Resp. n. . 474.704/PR, rel. Min. Carlos Alberto Menezes Direito, j. 17.12.2002). O referido julgado também foi abordado em DIREITO, Carlos Alberto Menezes. Direito positivo aplicado. Rio de Janeiro: Renovar: 2008. p. 433-439.
} 
Além disto, também cabe ao sócio ostensivo a prerrogativa de demandar e de pleitear determinados direitos em juízo. Portanto, a sociedade em conta de participação não possui legitimidade ad causam e ad processum, ativa ou passiva. ${ }^{93}$

Tendo em vista a sua característica de sociedade interna, apta a gerar direitos e obrigações entre os sócios ostensivos e os sócios participantes, eventuais controvérsias entre os seus sócios podem ser dirimidas mediante propositura de ação judicial. ${ }^{94}$ Portanto, os sócios da sociedade em conta de participação podem propor ações e dirimir, em juízo, controvérsias geradas entre si no âmbito da sociedade.

\section{III.4.3 Ausência de patrimônio próprio}

Este tema será tratado, de forma mais pormenorizada, no Capítulo IV, abaixo.

No entanto, é importante desde já mencionar que a ausência de personalidade jurídica possui como consequência imediata a ausência de patrimônio próprio da sociedade, já que, nesta circunstância, a sociedade não possui capacidade para ser titular de direitos reais.

\footnotetext{
${ }^{93}$ Convém destacar que há posicionamento doutrinário divergente, ainda que minoritário, a respeito deste tema. Donoso e Gumerato Ramos entendem que o fato de que o artigo 12, inciso VII do Código de Processo Civil prever que as sociedades sem personalidade jurídica poder demandar e ser demandado em juízo, via representação, faz com que as sociedades em conta de participação, que se caracterizam como sociedade sem personalidade jurídica, tenha legitimidade ad causam. (DONOSO, Denis; RAMOS, Glauco Gumerato. Sociedade em conta de participação em juízo: análise da sociedade em conta de participação à luz dos pressupostos processuais. Direito processual empresarial (Estudos em Homenagem a Manoel de Queiroz Pereira Calças). São Paulo: Campus Elsevier, 2012. p. 185-197).

Não concordamos com o entendimento exposto acima.

E mais, propomos uma alteração de lege ferenda no artigo 12, inciso VII do Código de Processo Civil para prever que apenas as sociedades em comum podem demandar e ser demandadas em juízo. A previsão deve, assim, restringir-se às sociedades em comum e não prever as sociedades sem personalidade jurídica em geral.

$\mathrm{O} \S 2^{\circ}$ do artigo 12 do Código de Processo Civil parece corroborar o entendimento de que o artigo 12 do referido diploma legal deve ser aplicado apenas às sociedades em comum e não a todas as sociedades sem personalidade jurídica. In verbis: "As sociedades sem personalidade jurídica, quando demandadas, não poderão opor a irregularidade de sua constituição."

${ }^{94}$ Neste sentido, vide decisão do Superior Tribunal de Justiça: "Comercial. Sociedade em conta de participação. Relações internas. Os participantes da sociedade em conta de participação podem, individualmente e em nome próprio, propor ações em Juízo para dirimir controvérsias sobre as respectivas relações internas. Recurso especial conhecido e provido." (Resp. n. ${ }^{\circ}$ 85240/RJ, rel. Min. Ari Pargendler, j. 19.11.1999).
} 
Em virtude deste fato, a sociedade em conta de participação não possui patrimônio próprio. As contribuições dos sócios são aportadas em um patrimônio especial alocado na esfera patrimonial do sócio ostensivo.

\section{III.4.4 Ausência de denominação ou firma social}

Uma das características da sociedade em conta de participação diz respeito à impossibilidade de conferir-lhe firma ou denominação social.

A referida impossibilidade de se conferir denominação ou firma social para as sociedades em conta de participação também decorre da já famigerada ausência de personalidade jurídica deste tipo societário e ausência de atuação perante terceiros. ${ }^{95}$

A sociedade em conta de participação não possui nome próprio e sequer o necessita pelo fato de não atuar no mundo jurídico em nome próprio. No entanto, não é vedado aos sócios atribuir-lhe caracteres aptos a identificá-la.

$\mathrm{Na}$ prática, isto ocorre, normalmente, nas situações em que um sócio participa de diversas sociedades em conta de participação. Nesta hipótese, a atribuição de caractere identificador pode facilitar o controle dos diversos patrimônios especiais, no caso dos sócios ostensivos, e também pode facilitar a contabilização e declaração das participações societárias, nos casos dos sócios ostensivos e dos sócios participantes.

SALGADO $^{96}$ defende que a utilização exacerbada de nome próprio pode fazer com que a sociedade em conta de participação usurpe as exterioridades de uma

\footnotetext{
95 Mauro Brandão Lopes esclarece que: "A proibição é de usar "firma", como nome sob o qual o comerciante exerce o comércio, nos termos do citado decreto n. 916. Como tal, não poderia a sociedade em conta de participação usá-la, porque o seu uso equivaleria à sua exteriorização, e consequente desvirtuamento. Na proibição, não se compreende, porém, o uso pelo sócio ostensivo, em sua escrituração, de uma designação de caráter social para individuar os negócios da conta de participação." (LOPES, Mauro Brandão. Ensaio sôbre a conta... cit., p. 80). No mesmo sentido: "Quando no Decreto n. ${ }^{\circ}$ 916 , de 24 de outubro de 1890 , art. $3^{\circ}, \S 4^{\circ}$ se diz que 'A sociedade em conta de participação não poderá ter firma que indicie a existência da sociedade", faltou-lhe precisão terminológica: a sociedade em conta de participação não pode ter firma, porque, se a tem, se caracteriza outro tipo; veda-se-lhe o uso de firma para a sociedade, embora exista, não aparece no registro, a respeito os terceiros, pela publicidade registrária. Existe, internamente; não se apresenta, lá fora, como pessoa jurídica, nem há relações jurídicas externas.” (PONTES DE MIRANDA, Francisco Cavalcanti. Op. cit., p. 320).

${ }^{96}$ SALGADO, Paulo Cavalcanti. Op. cit., p. 60.
} 
sociedade de fato, o que ensejaria a sua caracterização como verdadeira sociedade de fato e a aplicação das regras que lhes são próprias.

\section{III.4.5 Ausência de sede ou domicílio}

A sociedade em conta de participação não possui sede ou domicílio. Todavia, é possível que os sócios prevejam, no ato constitutivo da sociedade, que as atividades serão exercidas em um local pré-definido. Além disso, os atos constitutivos da sociedade também podem conter eleição do foro apto para dirimir eventuais controvérsias havidas entre os sócios.

\section{III.4.6 Prazo de duração da Sociedade em Conta de Participação}

Conforme exposto acima, durante a vigência do Código Comercial, em seu artigo 325, a sociedade em conta de participação era definida da seguinte forma:

(...) quando duas ou mais pessoas, sendo ao menos uma comerciante, se reúnem, sem firma social, para lucro comum, em uma ou mais operações de comércio determinadas, trabalhando um, alguns ou todos em seu nome individual para o fim social, a associação toma o nome de sociedade em conta de participação, acidental, momentânea ou anônima (...).

Em virtude da definição elencada acima, durante a vigência do Código Comercial havia a discussão a respeito do prazo de duração da sociedade em conta de participação.

Isto porque, a partir do dispositivo legal em referência, determinados juristas brasileiros defendiam que a sociedade em conta de participação era uma sociedade momentânea, transitória, acidental, visando a uma só ou apenas determinadas operações, não podendo, por isso, ter caráter permanente ou objetivar todo um ramo de negócio. ${ }^{97}$

\footnotetext{
${ }^{97}$ Pensa assim Waldemar Ferreira. In verbis: "Não se destina a vida duradoura, senão transitória ou passageira, de molde até a extinguir-se momentos depois de constituída, pela realização da operação de comércio a que se destinava. (...) O prazo de vigência da sociedade em conta de participação há de ser
} 
No entanto, ainda sob a égide do Código Comercial havia discussões e divergências a este respeito, sendo certo que o entendimento de que as sociedades em conta de participação eram momentâneas já não era predominante na época. ${ }^{98}$

A partir da vigência do Código Civil de 2002, esta divergência parece estar resolvida, já que não há dispositivo legal que preveja que a sociedade em conta de participação tem por objeto o exercício de uma ou mais operações determinadas e que se caracteriza como sociedade acidental e momentânea.

$\mathrm{Na}$ verdade, a sociedade em conta de participação pode ser constituída para um propósito específico que, após o seu alcance, ensejará sua dissolução. No entanto, também há a possibilidade de constituição da sociedade em conta de participação para o exercício de negócios duradouros e contínuos.

\section{III.4.7 Ausência de requisitos formais}

A sociedade em conta de participação é constituída por simples consenso dos sócios, desde que respeitados os requisitos gerais necessários para a formação de negócios jurídicos e de contratos, conforme previsto no artigo 104 do Código Civil de 2002, bem como os requisitos especiais para a formação de contratos plurilaterais.

indeterminado, adstrito, como fica, à ultimação do negócio para cuja realização se constitui. O caráter próprio dessa sociedade, no ensinamento de Pardessus, está em que ela é relativa a uma ou mais operações de comércio, cujo objeto nasce no momento em que as partes se ajustam e não deve prolongarse além do tempo necessário para ultimá-las. Se as demais sociedades se destinam à prática de operações continuadas sucessivamente, em perene renovação, por anos a fio, o mesmo não acontece com a sociedade em conta de participação, de vida transitória e efêmera, na generalidade dos casos." (FERREIRA, Waldemar. Op. cit., p. 507-511).

${ }^{98}$ Conforme entende Pontes de Miranda, para quem a ocasionalidade, a eventualidade, a transitoriedade, que muitos consideram elementos característicos da sociedade em conta de participação, de modo nenhum o é. (...) No passado, a doutrina francesa e as de outros Estados sustentaram que a sociedade em conta de participação tinha de ser momentânea. Isso apenas é o que mais acontece. Não se pode considerar elemento característico. A série de operações pode ser longa. (...) Quando a operação é ocasional, de alguns dias ou semanas, como em festa de ano bom, ou de Natal, ou de algum centenário, compreende-se que os interessados em laço societário prefiram a composição da sociedade em conta de participação. Raramente a atividade comercial duradoura adapta-se à figura da sociedade em conta de participação. Mas os sindicatos financeiros são exemplos de tais sociedades permanentes. Se o negócio é um só, ou se compõe de série finita de negócios jurídicos (alienação de ações de empresa), a duração da sociedade é a que corresponde a prática da operação ou das operações. Um dos exemplos de sociedade em conta de participação sem prazo determinado, mas duradoura, ocorre, por vezes, na indústria jornalística (PONTES DE MIRANDA, Francisco Cavalcanti. Op. cit., p. 332-333). 
A constituição da sociedade em conta de participação independe, portanto, de formalidades e admite provas por todos os meios de direito, conforme preconiza o artigo 992 do Código Civil de 2002. ${ }^{99}$

\section{III.4.8 Eventual possibilidade de emissão de títulos negociáveis}

As sociedades em conta de participação não podem emitir títulos negociáveis.

A proibição de as sociedades em conta de participação emitirem títulos negociáveis guarda estreita relação com as características intrínsecas a este tipo societário, ou seja, decorre da ausência de personalidade jurídica e de patrimônio próprio. ${ }^{100}$ No entanto, o sócio ostensivo pode emitir títulos negociáveis. ${ }^{101}$

\footnotetext{
${ }^{99}$ A este respeito: “As sociedades em conta de participação quase sempre se constituem por escrito. A forma escrita não é, porém, pressuposto essencial. Raramente se conclui o contrato por escritura pública. $\mathrm{O}$ mais das vezes, faz-se por meio de correspondência. As cartas permitem o sigilo e pode ocorrer que sejam endereçadas ao sócio participante ativo, de modo que os outros participantes, os inativos, ignorem quais são os figurantes do contrato e somente conheçam o sócio participante ativo.” (Idem, p. 336).

${ }^{100}$ A este respeito Pontes de Miranda. In verbis: "As participações são, de regra, em quotas, à semelhança do que se passa nas sociedades em nome coletivo, ou na sociedade em comandita simples. Os direitos pessoais, que delas resultam, não são transferíveis, nem negociáveis, sem as quotas; nem deles emana qualquer título de crédito. (...) Os estatutos podem prever a substituição dos sócios participantes, desde que não torne título negociável a quota da participação. Se nada se previu, é preciso a unanimidade do assentimento dos outros sócios participantes. Salvo nos casos de dissolução eventual da sociedade, há a sucessão a causa de morte." (Idem, p. 334-335).

${ }^{101}$ Para GRANDI (GRANDI, Salvatore Giovanni. L'associazione in partecipazione. Milano: Casa Editrice Dottor Francesco Vallardi, 1939. p. 92), se não se pode conceber que a Conta de Participação emita títulos, deve-se admitir que o sócio ostensivo possa fazê-lo. Estes papéis indicariam que o sócio oculto participa na proporção "x" e que conferiu " $y$ ". Contudo, GRANDI, citando Grasca, esclarece que o documento só tem o valor de um recibo. Não é um título de crédito. E, quando for nominativo, não poderá ser transmitido a outrem (ALMEIDA, José Gabriel de Assis de. A sociedade em conta de participação. Rio de Janeiro: Forense, 1989. p. 103-104).

A este respeito, Paulo Cavalcanti Salgado menciona que: "Alguns escriptores opinam pela possibilidade de dividirem as sociedades em conta de participação o seu capital em acções. Vidari, sem aprovar em absoluto esta tendência, pensa que ella é jurídica, com algumas restricções. Assim, é de sentir que as acçoes não devem ser intituladas em nome da sociedade, pois esta perderia o seu caracter de oculta, com a negociação das mesmas. Para obviar este inconveniente lembra o insigne professor a idea de se estipular a inalienabilidade das mesmas acções, ou intestal-as em nome do sócio ostensivo. O primeiro meio, aos seus olhos, tirará à acção, os seus caracteres; não obstante, elle conclue que os contractantes podem dividir em partes iguaes o fundo comum e emitir títulos representativos d'estas partes. O primeiro expediente lembrado por Vidari fruta o argumento dos que acreditam que a permissão concedida a estas sociedades, de emitir acções, desvirtua a sua natureza pessoal dos participantes. Pensamos que, mesmo mantido o caracter pessoal da parte de cada participante, o facto de ser esta parte certificada por um título, inalienável, não modifica a índole da sociedade em conta de participação. Mas este titulo que prova a parte que cada sócio tem na sociedade será uma acção si lhe falta o caracter de negociável, que distingue a acção da parte do interesse a quota nas sociedades de pessoas? Convenhamos, pois, que Vidari com os
} 
A este respeito, convém destacar as sociedades em conta de participação constituídas com o objetivo de participar de projetos de reflorestamento.

Neste caso, as sociedades reflorestadoras são sócias ostensivas e os investidores são sócios participantes e o objeto da sociedade em conta de participação é a alienação de parcelas do plantio das árvores após o reflorestamento.

O Decreto-lei n. ${ }^{\circ} 1.134$, de 16 de novembro de 1970, criou duas estruturas societárias para o fim de aplicação em projetos de reflorestamento e obtenção de incentivos fiscais.

O caput do artigo $1^{\mathrm{o}}$ do Decreto-lei n. ${ }^{\mathrm{o}} 1.134 / 70$ prevê que: ${ }^{102}$

a partir do exercício financeiro de 1971, as pessoas jurídicas poderão descontar até $50 \%$ (cinquenta por cento) do valor do imposto de renda devido na declaração de rendimentos, para a aplicação em empreendimentos florestais, cujos projetos tenham sido aprovados pelo Instituto Brasileiro de Desenvolvimento Florestal.

O parágrafo $1^{\circ}$ do referido artigo prevê, ainda, que:

as importâncias descontadas poderão ser aplicadas em projetos de desenvolvimento florestal opcionalmente, sob a forma de: (I) Participação societária acionária; (II) Participação societária não acionária em projetos de pluri-participação.

Posteriormente, o Decreto n. ${ }^{\text {o } 79.046, ~ d e ~} 27$ de dezembro de $1976^{103}$ previu, em seu artigo 27, que:

Às sociedades em conta de participação, regidas pelos artigos 325 e 328 do Código Comercial Brasileiro ficam equiparadas as sociedades não acionárias de pluriparticipação (...). ${ }^{104}$

\footnotetext{
temperamentos propostos cahe na fileira dos que negam à sociedade em conta de participação a faculdade de emitir acções. (SALGADO, Paulo Cavalcanti. Op. cit., p. 90).

${ }^{102}$ Disponível em: <www.planalto.gov.br>. Acesso em: 20 set. 2013.

${ }^{103}$ Disponível em: <www.planalto.gov.br>. Acesso em: 20 set. 2013.

${ }^{104} \mathrm{O}$ referido Decreto previu, ainda, em seu artigo 27 , parágrafos $1^{\circ}, 2^{\circ}$ e $3^{\circ}$ que as pessoas jurídicas quotistas do Fundo de Investimento Setoriais - FISET - Florestamento e Reflorestamento que converterem suas quotas em títulos de capital de sociedade em conta de participação ficam equiparadas aos sócios participantes destas. E, ainda, que a sócia gerente ou administrativa da sociedade em conta de participação é a responsável pelo empreendimento florestal e sua representante legal perante o IBDF. A responsabilidade da sócia gerente, beneficiária do projeto, não excluirá a responsabilidade da executora que, por culpa, deixar de satisfazer os serviços contratados.
} 
O artigo 28 do Decreto n. ${ }^{\circ}$ 79.046/76 prevê que:

No caso de sociedade em conta de participação, a sócia gerente ou administradora emitirá em nome do Fundo de Investimento Setoriais - FISET - Florestamento e Reflorestamento "Certificados de Participação em Reflorestamento" representativos da participação daquele Fundo no empreendimento florestal, em decorrência da liberação de incentivos fiscais. ${ }^{105}$

Ainda é importante mencionar que a Instrução Normativa n. ${ }^{\circ} 179$ da Secretaria da Receita Federal, de 30 de dezembro de 1987, ${ }^{106}$ prevê que os certificados de investimento correspondentes às sociedades em conta de participação serão emitidos em nome do sócio ostensivo.

Portanto, há previsão expressa na legislação pátria a respeito da possibilidade do sócio ostensivo emitir títulos negociáveis.

Convém analisar, à luz da previsão legislativa a respeito do tema, se a existência de títulos negociáveis faz com que as sociedades em conta de participação que contam com sócios ostensivos emissores de certificados constituem sociedade de capital, na qual a affectio societatis não se faz obrigatória, ou se as referidas sociedades continuam com característica de sociedade de pessoas, o que faz com que a transferência dos títulos dependa da aprovação de todos os sócios.

ALMEIDA $^{107}$ entende que na conta de participação criada para incentivos fiscais, o intuitu personae que liga os sócios não é muito forte, Em geral, os contribuintes não aderem a estas sociedades com o objetivo principal de explorar o florestamento. A real motivação é o benefício fiscal, não sendo, para eles, de fundamental importância a pessoa dos demais sócios.

\footnotetext{
105 A respeito dos Certificados de Participação em Reflorestamento, há determinadas decisões judiciais que discutem, sobretudo, a respeito da eventual possibilidade de utilização dos referidos certificados e a respeito da ausência de prestação de contas pelo sócio ostensivo. Neste sentido: TRF $3^{\mathrm{a}}$ R., Apelação Cível n. ${ }^{\circ}$ 55333, j. 10.07.2008; TJRS, Apelação Cível n. ${ }^{\circ}$ 70050586379, j. 12.11.2012; TJPR, Ação Ordinária n. ${ }^{\circ} 798135-1$, j. 05.06.2012.

${ }^{106}$ Disponível em: <www.receita.fazenda.gov.br>. Acesso em: 20 set. 2013.

${ }^{107}$ ALMEIDA, José Gabriel de Assis de. Op. cit., p. 96-108.
} 
A este respeito, entendemos que deve ser aplicada a previsão contida no artigo 995 do Código Civil de 2002, ${ }^{108}$ que prevê que, salvo estipulação em contrário, o sócio ostensivo não pode admitir novo sócio sem o consentimento expresso dos demais.

Assim, entendemos que o instrumento de constituição da sociedade em conta de participação deverá prever expressamente a possibilidade de o sócio ostensivo emitir e transferir títulos representativos dos fundos sociais.

Nesta hipótese, ao celebrar o contrato de sociedade em conta de participação os sócios já terão anuído com a possibilidade da emissão de títulos e o ingresso de novos sócios em decorrência da transferência de certificados.

Caso o contrato da sociedade em conta de participação não contenha previsão expressa a respeito da possibilidade de emissão de títulos negociáveis, entendemos que a emissão dos certificados pelo sócio ostensivo pode ser questionada e, ademais, a transferência dos certificados não poderá ocorrer sem o consentimento de todos os sócios.

Além disso, a disciplina aplicável à admissão de novos sócios, conforme prevista no artigo 995 do Código Civil de 2002, corrobora o fato de que a alteração do contrato de sociedade em conta de participação deve ser aprovada por todos os sócios.

\section{III.5 Aspectos fiscais da sociedade em conta de participação}

Este item abordará, de forma breve, os aspectos fiscais das sociedades em conta de participação.

É importante ressaltar que este item não tem o objetivo de esgotar os temas fiscais a respeito das sociedades em conta de participação, mas somente de traçar um panorama geral a esse respeito.

Não obstante o fato de que as sociedades em conta de participação não terem personalidade jurídica, a legislação tributária federal equipara o referido tipo societário às demais pessoas jurídicas. ${ }^{109}$

\footnotetext{
${ }^{108}$ Disponível em: <www.planalto.gov.br>. Acesso em: 20 set. 2013.
} 
A este respeito, os artigos 148 e 149 do Decreto n. ${ }^{\circ} 3000$, de 26 de março de 1999 ("RIR") preveem que as sociedades em conta de participação são equiparadas às pessoas jurídicas e que na apuração dos resultados dessas sociedades, assim como na tributação dos lucros apurados e dos distribuídos, serão observadas as normas aplicáveis às pessoas jurídicas em geral e o disposto no art. 254 , II. ${ }^{110}$

O artigo 254, inciso II, do RIR, por sua vez, prevê que os resultados e o lucro real correspondente à sociedade em conta de participação deverão ser apurados e demonstrados destacadamente dos resultados e do lucro real do sócio ostensivo, ainda que a escrituração seja feita nos mesmos livros.

A Instrução Normativa n 179 da Secretaria da Receita Federal, de 30 de dezembro de 1987, prevê que compete ao sócio ostensivo a responsabilidade pela apuração dos resultados, apresentação da declaração de rendimentos e recolhimento do imposto devido pela sociedade em conta de participação. ${ }^{111}$

A escrituração das sociedades em conta de participação deve ser realizada em livros próprios da referida sociedade ou em livros do sócio ostensivo, sendo certo que nesta última hipótese o sócio ostensivo deverá destacar, de forma clara, as contas próprias da sociedade em conta de participação. ${ }^{112}$

\footnotetext{
${ }^{109}$ Quando também despersonalizada para fins tributários, a sociedade em conta de participação não pagava tributos. "Por essa razão, a modalidade de investimento comum apresentava, em relação às sociedades empresárias, uma vantagem, do ponto de vista do planejamento fiscal. Alguns empreendimentos de vulto foram explorados sob a forma de contas de participação. O empreendedor preservava o seu patrimônio, por meio de um expediente simples: constituía uma sociedade limitada, com um ou mais parceiros, e esta celebrava os contratos, na condição de sócia ostensiva". (ULHOA COELHO, Fabio. Curso de Direito Comercial. 5. ed. v. 2. São Paulo: Saraiva, 2002. p. 477).

${ }^{110}$ A este respeito, vide também Ato Declaratório Interpretativo $n^{\circ}$ 14/2004 da Secretaria da Receita Federal, que disciplina a tributação das atividades do sistema de locação conjunta de unidades imobiliárias denominado de pool hoteleiro e que dispõe em seu artigo único, $\S 1^{\circ}$ : "As SCP são equiparadas às pessoas jurídicas pela legislação do Imposto de Renda, e, como tais, são contribuintes do Imposto de Renda das Pessoas Jurídicas (IRPJ), da Contribuição Social sobre o Lucro Líquido (CSLL), da Contribuição para o PIS/Pasep e da Contribuição para o Financiamento da Seguridade Social (Cofins)."

${ }^{111}$ A esse respeito, vide Solução de Consulta n. ${ }^{\circ}$ 03, de 25.01.96: "O sócio ostensivo assume, em decorrência de previsão legal (art. 991 do CC), a responsabilidade pelos tributos e contribuições sociais devidos pela SCP. Assim sendo, enquanto perdurar um parcelamento anterior no CNPJ do sócio ostensivo, seja o mesmo decorrente de autuações próprias ou da SCP, há vedação à concessão de um novo parcelamento".

${ }^{112}$ Conforme Instrução Normativa n. ${ }^{\circ} 179 / 87$ da Secretaria da Receita Federal.
} 
Tendo em vista a equiparação da sociedade em conta de participação às demais pessoas jurídicas, os lucros apurados e distribuídos aos seus sócios, a partir do mês de janeiro de 1996, são isentos do imposto de renda, não se sujeitando à incidência na fonte ou na apuração pelo beneficiário, pessoa física ou jurídica, domiciliado no País ou no exterior, conforme previsto na Lei n. ${ }^{\circ}$ 9.249, de 26 de dezembro de 1995, em seu artigo $10 . .^{113}$

Da mesma forma, os ajustes de investimentos detidos pelos sócios em decorrência da aplicação do Método de Equivalência Patrimonial - MEP - também não geram efeitos fiscais, conforme artigo 389 do RIR.

Os prejuízos apurados pela sociedade em conta de participação serão contabilizados separadamente das demais rubricas do sócio ostensivo de forma que somente é possível a compensação dos prejuízos com os lucros da mesma sociedade, observada a legislação vigente. Desta forma, o prejuízo apurado pela sociedade em conta de participação não poderá ser compensado com o lucro real do sócio ostensivo ou de outras sociedades em conta de participação. ${ }^{114}$

O Manual de Orientação para Preenchimento da Declaração de Imposto de Renda - MAJUR - prevê que a pessoa jurídica que for sócia ostensiva de sociedade em conta de participação deve informar na Declaração de Imposto de Renda Pessoa Jurídica - DIPJ - os valores referentes ao imposto de renda e contribuições apurados por todas as sociedades em conta de participação.

As sociedades em conta de participação não estão obrigadas a se inscrever no Cadastro Nacional de Pessoa Jurídica - CNPJ, conforme previsto no item 4 da Instrução Normativa da Secretaria da Receita Federal n. ${ }^{\circ}$ 179/1987.

No entanto, apesar da inexistência da obrigatoriedade de inscrição, é possível que o sócio ostensivo obtenha Cadastro Nacional de Pessoa Jurídica - CNPJ para a sociedade em conta de participação. Essa possibilidade está regulada na Instrução Normativa n. ${ }^{\circ}$ 1.005/2010 da Secretaria da Receita Federal.

\footnotetext{
${ }^{113}$ Disponível em: <www.planalto.gov.br>. Acesso em: 10 out. 2013.

${ }^{114}$ Conforme Instrução Normativa n. ${ }^{\circ}$ 179/87 da Secretaria da Receita Federal.
} 
Assim, tendo em vista que as sociedades em conta de participação não estão obrigadas à inscrição no Cadastro Nacional de Pessoa Jurídica - CNPJ, a Instrução Normativa n. ${ }^{\circ}$ 179/1987 da Secretaria da Receita Federal prevê que o imposto e a contribuição para o Programa de Integração Social - PIS - serão pagos juntamente com o imposto e a contribuição para o PIS devidos pelo sócio ostensivo, por meio do mesmo DARF. $^{115}$

E, ainda, a referida Instrução Normativa prevê que os demais tributos federais e a contribuição para o FINSOCIAL correspondentes à sociedade em conta de participação serão, também, pagos em nome do sócio ostensivo, bem como que a opção para aplicação do imposto em investimentos regionais e setoriais incentivados, correspondente à sociedade em conta de participação, será efetuada pelo sócio ostensivo, em sua própria declaração de rendimentos.

A Instrução Normativa n. ${ }^{\circ} 247$ da Secretaria da Receita Federal, de 21 de novembro de 2002, que disciplina o PIS/Pasep e Cofins prevê, em seu artigo 80, que o sócio ostensivo deve efetuar o pagamento das contribuições incidentes sobre a totalidade da receita bruta da sociedade em conta de participação, não sendo permitida a exclusão de valores devidos aos sócios ocultos. ${ }^{116-117}$

\footnotetext{
${ }^{115}$ Convém ressaltar, no entanto, que a Instrução Normativa n. ${ }^{\circ}$ 31, de 29 de março de 2001 da Secretaria da Receita Federal prevê, em seu artigo $1^{\circ}$, $\S 2^{\circ}$ que: "O recolhimento dos tributos e contribuições devidos pela sociedade em conta de participação será efetuado mediante a utilização de Darf específico, em nome do sócio ostensivo."

${ }^{116}$ Disponível em: <www.receita.fazenda.gov.br>. Acesso em: 10 out. 2013.

${ }^{117}$ Convém destacar a respeito do recolhimento de PIS e COFINS que as sociedades em conta de participação já foram utilizadas de forma a tentar configurar, no caso de exploração de flats, que os alugueis pagos seriam destinados aos sócios participantes, enquanto que a remuneração pelos serviços prestados seria destinada ao sócio ostensivo. Com essa "divisão" procurava-se evitar a tributação do PIS/COFINS, já que as pessoas físicas não pagam as contribuições sociais. Ocorre que a Secretaria da Receita Federal do Brasil (RFB) emitiu determinação interna orientando seus fiscais como seria o tratamento tributário de tais sociedades: "São receitas ou resultados próprios da SCP, exemplificativamente, sujeitando-se às normas de tributação específicas do IRPJ, da CSLL, da Contribuição para o PIS/Pasep e da Cofins: as diárias, semanadas ou aluguéis, relativos às unidades integrantes do pool hoteleiro, inclusive de áreas de restaurantes, salão de convenções, lojas, etc., também integrantes do sistema de locação conjunta; os preços dos serviços prestados, os impostos e taxas incidentes sobre os imóveis, e os demais encargos locatícios, se cobrados, pela administradora, destacadamente das diárias, semanadas ou aluguéis; as indenizações recebidas por extravios e danos causados às unidades; as multas e juros de mora; o resultado das aplicações dos saldos financeiros da sociedade."
} 
A Secretaria da Receita Federal, até o ano de 2000, entendia que os lucros apurados pelo sócio ostensivo e os lucros apurados pela sociedade em conta de participação deveriam obedecer ao regime de tributação com base no lucro real. ${ }^{118}$

A partir de $1^{\circ}$ de janeiro de 2001, as sociedades em conta de participação foram autorizadas pela Receita Federal a optar pelo regime de tributação com base no lucro presumido, desde que observadas as demais regras para a sua opção, previstas na legislação tributária. ${ }^{119}$

A Secretaria da Receita Federal já se manifestou no sentido de que a sociedade em conta de participação, bem como seu sócio ostensivo, podem, conjuntamente, optar pelo regime de tributação com base no lucro presumido, ainda que a soma de suas receitas totais, no ano-calendário anterior, ultrapasse o limite fixado pela legislação vigente. ${ }^{120}$

Ademais, a sociedade em conta de participação pode ser tributada por sistemática de apuração do lucro distinta da sistemática utilizada pelo sócio ostensivo. Assim, os resultados da conta de participação podem ser tributados pela sistemática do lucro presumido, mesmo que o sócio ostensivo esteja submetido ao lucro real e viceversa. $^{121}$

O item 9 da Instrução Normativa n. ${ }^{\circ}$ 179/1987 prevê que em caso de alienação de participação em sociedade em conta de participação, o ganho ou perda de capital será apurado segundo os mesmos critérios aplicáveis à alienação de participação societária em outras pessoas jurídicas.

Já o item 6 da Instrução Normativa n. ${ }^{\circ}$ 179/1987 prevê que os valores entregues ou aplicados na sociedade em conta de participação, pelos sócios pessoas jurídicas, deverão ser por eles classificados em conta do ativo permanente, em

\footnotetext{
${ }^{118}$ Inclusive, essa previsão está contida no artigo $1^{\circ}$ da Instrução Normativa n. ${ }^{\circ} 179 / 87$ da Secretaria da Receita Federal. In verbis: Os resultados das sociedades em conta de participação - SCP, deverão ser apurados, em cada período-base, com observância das disposições do artigo 16 da Lei $\mathrm{N}^{\circ} 7.450$, de 23 de dezembro de 1985, e demais normas fiscais aplicáveis às pessoas jurídicas tributadas com base no lucro real, inclusive quanto à correção monetária das demonstrações financeiras.

${ }^{119}$ Conforme Instrução Normativa da Secretaria da Receita Federal n. ${ }^{\circ}$ 31/2001. Conforme Soluções de Consulta da Secretaria da Receita Federal n. ${ }^{\circ}$ 13/2000, DOU 15.03.2000; n..$^{\circ}$ 51/2000, DOU 13.09.2000 e n. ${ }^{\circ}$ 197/2000, DOU 29.11.2000.

${ }^{120}$ Solução de Consulta da Secretaria da Receita Federal n. ${ }^{\circ}$ 63/2006, DOU 19.09.2006.

${ }^{121}$ Conforme Instrução Normativa da Secretaria da Receita Federal n. ${ }^{\circ}$ 31/2001.
} 
conformidade com o disposto no artigo 179, item III, da Lei n. ${ }^{\circ}$ 6.404, de 15 de dezembro de 1976 ("Lei das Sociedades por Ações”), estando sujeitos aos critérios de avaliação previstos na referida Lei das Sociedades por Ações e no Regulamento de Imposto de Renda.

Os valores entregues pelos sócios, pessoas jurídicas, somados aos valores entregues pelos sócios, pessoas físicas, constituirão o capital da sociedade em conta de participação, que será registrado em conta que represente o patrimônio líquido desta. ${ }^{122}$

Os lucros recebidos de investimento em sociedade em conta de participação, avaliados pelo custo de aquisição, ou a contrapartida do ajuste do investimento ao valor do patrimônio liquido da sociedade em conta de participação, no caso de investimento avaliado por este método, não serão computados na determinação do lucro real dos sócios, pessoas jurídicas, das referidas sociedades. ${ }^{123}$

Os rendimentos pagos pela sociedade em conta de participação, bem como os lucros apurados até 31.12.1995, e por elas distribuídos serão tributados na fonte, nos termos da legislação aplicável às demais pessoas jurídicas. O imposto incidente na fonte terá, nos beneficiários dos rendimentos, o mesmo tratamento dado ao imposto retido na fonte pelas demais pessoas jurídicas. Os lucros ou dividendos calculados com base nos resultados apurados a partir do mês de janeiro de 1996, pagos ou creditados pelas pessoas jurídicas tributadas com base no lucro real, presumido ou arbitrado, não ficarão sujeitos à incidência do imposto de renda retido na fonte, nem integrarão a base de cálculo do imposto de renda do beneficiário, pessoa física ou jurídica, domiciliado no País ou no exterior. ${ }^{124}$

\footnotetext{
${ }^{122}$ Conforme Instrução Normativa n. ${ }^{0}$ 179/1987 da Secretaria da Receita Federal, item 6.1.

${ }^{123}$ Conforme Instrução Normativa n. ${ }^{\circ}$ 179/1987 da Secretaria da Receita Federal, item 7.

${ }^{124}$ Conforme Instrução Normativa n. ${ }^{\circ} 179 / 1987$ da Secretaria da Receita Federal, item 8 e 8.1, bem como Lei n. ${ }^{\circ}$ 9.249/95, art. 10. No mesmo sentido, vide interpretação da Secretaria da Receita Federal ao artigo 10 da Lei n. ${ }^{\circ}$ 9.245/95: "Não estão sujeitos à incidência do Imposto de Renda na Fonte os lucros apurados a partir de $1^{\circ}$ de janeiro de 1996, pagos ou creditados por sócio ostensivo de Sociedade em Conta de Participação (SCP) à pessoa física (sócio oculto), desde que apurados e demonstrados destacadamente dos resultados apurados pelo sócio ostensivo, ainda que a escrituração seja feita nos mesmos livros (SC 11/2009 - SRRF, $8^{\mathrm{a}}$ RF, DOU 09.02.2009).
} 
RAMIRES $^{125}$ mencionou que no que toca ao IPI, causa estranheza a Secretaria da Receita Federal do Brasil dar determinado tratamento fiscal a IRPJ, CSLL, PIS e COFINS, e afastar-lhe daquele tributo, devendo-se assim promover o seu recolhimento de forma conjunta ao sócio ostensivo, segundo o valor apurado no Livro de Registro de Apuração do IPI e informado na Declaração de Imposto de Renda Pessoa Jurídica -DIPJ.

O referido autor mencionou ainda que quanto ao ICMS, em virtude da ausência de convênio que preveja a uniformidade fiscal a todos os entes fiscais estaduais, os mais diversos Estados foram percorridos para certificar a real existência de tratamento diferenciado. ${ }^{126}$

Por fim, é importante citar, a respeito do tema sucessão tributária, caso analisado por MARIZ DE OLIVEIRA. ${ }^{127}$ No caso, a discussão envolvia a eventual possibilidade da sociedade WB \& Cia. Ltda. ser considerada sucessora tributária da CB

${ }^{125}$ RAMIRES, Rogério. A sociedade em conta de participação no direito brasileiro. São Paulo: Almedina, 2011. p. 168-169.

${ }^{126}$ No Estado de Minas Gerais, foi localizada a seguinte solução a consulta. Consulta de Contribuinte n. ${ }^{\circ}$ 038/2004.

Consulta: o contribuinte, inscrito no Cadastro de Contribuinte deste Estado, informa que exerce a atividade de incorporação, construção e venda de imóveis próprios. Narra que, com o intuito de agilizar suas operações de construção de imóveis residenciais, constitui parcerias com outras empresas, através de sociedades denominadas "Sociedades em Conta de Participação", prevista no art. 991 do Código Civil. Esclarece que atua como sócio ostensivo, obrigando-se perante terceiros pelos atos de tais sociedades. Acrescenta que a empresa não está sujeita ao recolhimento do ICMS por não ser contribuinte do imposto, mas está sujeita ao cumprimento das obrigações acessórias. Isso colocado, em dúvida quanto ao preenchimento dos dados no Sistema Integrado de Informações sobre Operações Interestaduais com Mercadorias e Serviços (Sintegra), indaga:

1. É correto agrupar os dados dos fornecedores de material e serviços lançados na escrita contábil da SCP aos dados do sócio ostensivo, no caso, o Consulente?

2. Caso contrário, como devemos proceder com relação aos dados existentes em nome da SCP, já que o Sintegra não aceita enviar dois arquivos diferentes para a mesma inscrição estadual?

Resposta: (...) Não há referência a este tipo de sociedade na legislação do ICMS, uma vez que referida sociedade não é contribuinte do imposto estadual. O contribuinte, neste caso, é o sócio ostensivo, sobre o qual recai todas as obrigações do contribuinte do ICMS contidas no art. 96, parte geral do RICMS/02. Assim, considerando que a existência da SCP não afeta os tributos estaduais e que a legislação do ICMS não faz referência a este tipo de sociedade, o contribuinte (sócio ostensivo), quando do registro dos dados em tal sistema (Sintegra), deverá considerar a regra prevista no Convênio ICMS 57/95 e alterações e no Anexo VII do RICMS/02. Desse processo, resulta informar que o pedido de uso de Sistema de Processamento Eletrônico de Dados (PED), quer seja para escrituração de Livros Fiscais quer seja para a emissão de documentos fiscais, é autorizado para o contribuinte, que é único. Portanto, deve ser transmitido um único arquivo com todas as informações, inclusive quando a escrituração fiscal for feita em escritório de contabilidade.

${ }^{127}$ MARIZ DE OLIVEIRA, Ricardo. Inexistência de sucessão tributária ao Imposto de Renda do caso de simples aquisição de imóvel comercial, exploração da mesma atividade no local e anterior existência de sociedade em conta de participação com o antigo proprietário. Direito Tributário Atual. (Resenha tributária - v. 6). São Paulo: Instituto Brasileiro de Direito Tributário, 1982. p. 1.431-1.495. 
Ltda. em decorrência de ter adquirido desta última determinado imóvel, sendo que no local a CB Ltda. operava como sócia ostensiva de sociedade em conta de participação e a WB \& Cia. Ltda. figurava como sócia participante.

MARIZ DE OLIVEIRA ${ }^{128}$ entendeu que:

\begin{abstract}
Não se pode falar em responsabilidade da WB \& Cia. Ltda. sobre imposto de renda devido pela CB Ltda. só porque houve entre ambas sociedade em conta de participação e esta foi extinta. Não se pode falar assim por que: (i) a sociedade em conta de participação não é pessoa jurídica, o que exclui a hipótese concreta da maior abrangência do CTN, parágrafo único do art. 132; (ii) ainda que houvesse pessoa jurídica, a sua extinção ou cessão irregular de atividade só atribuiria responsabilidade a sócio pessoa física que prosseguisse explorando sua atividade, ou a sócio com poder de administração (que legalmente não é o caso do sócio oculto em sociedade em conta de participação), na regra especial para imposto de renda contida no Decreto-lei n. ${ }^{\circ} 1.598$.
\end{abstract}

Diante dos aspectos tributários mencionados acima, há autores ${ }^{129}$ que defendem o registro das sociedades em conta de participação em Cartório de Títulos e Documentos para o fim de constituir prova inequívoca da existência da sociedade e, por consequência, das regras tributárias incidentes.

\footnotetext{
${ }^{128}$ MARIZ DE OLIVEIRA, Ricardo. Op. cit., p. 1.431-1.495.

${ }^{129}$ Como por exemplo, Bernardo Lopes Portugal. PORTUGAL, Bernardo Lopes. A sociedade em conta de participação no novo Código Civil e seus aspectos tributários. In: RODRIGUES, Frederico Viana (Org.). Direito de Empresa no Novo Código Civil. Rio de Janeiro: Forense, 2004. p. 163.
} 


\section{CAPÍTULO IV O PATRIMÔNIO DA SOCIEDADE EM CONTA DE PARTICIPAÇÃO}

\section{IV.1 Teorias do patrimônio}

Inicialmente, é importante esclarecer que este item não tem a pretensão de apresentar um estudo aprofundado e detalhado a respeito das teorias do patrimônio. Ao contrário, sua finalidade é retratar, em linhas gerais, uma sucinta descrição das teorias do patrimônio de forma a subsidiar o entendimento das linhas mestras deste tema para o fim de, ato contínuo, analisar de forma mais pormenorizada o patrimônio separado das sociedades em conta de participação.

Este item também não tem por objetivo apresentar análises civilistas a respeito das teorias e conceito de patrimônio.

Existem diversas teorias a respeito do patrimônio. ${ }^{130}$

A teoria clássica, de AUBRY E RAU, ${ }^{131}$ enquadra o patrimônio como uma universalidade de direito e pode ser classificada como personalista, já que defende que: (i) somente as pessoas podem ter patrimônio, (ii) toda pessoa tem necessariamente um patrimônio, (iii) toda pessoa não pode ter senão um patrimônio.

Portanto, de acordo com a teoria clássica, a unificação do patrimônio dá-se pela unidade da pessoa e, como uma pessoa não pode ser dividida, o mesmo ocorre com o patrimônio. A referida teoria preconiza as seguintes características do patrimônio: unidade - todo sujeito de direito tem somente um patrimônio -, indivisibilidade - o patrimônio é incindível - e inalienabilidade - os bens que compõe o patrimônio podem ser alienados isoladamente, mas não o próprio patrimônio.

\footnotetext{
${ }^{130}$ Conforme DONATO, Milena Oliva. Patrimônio separado: herança, massa falida, securitização de créditos imobiliários, incorporação imobiliária, fundos de investimento imobiliário, trust. São Paulo: Renovar, 2009 e, também, conforme CUNHA, Paulo A. V. Do patrimônio - Estudo de direito privado. v. I. n. 64. Lisboa: Minerva, 1934. p. 148 e ss.

${ }^{131}$ AUBRY, Rau. Cours de Droit Civil Français d'après la méthode de Zachariae. Paris: Marchal \& Billard, 1917. p. 334.
} 
A partir da teoria clássica, surgiram determinadas outras concepções personalistas e também vertentes não personalistas a respeito do patrimônio.

A segunda concepção também é personalista, já que relaciona o patrimônio à personalidade. No entanto, esta concepção admite exceções legislativas contrárias ao postulado clássico. BIANCHI ${ }^{132}$ é considerado representante desta segunda concepção. A referida concepção classifica o patrimônio como uma universalidade de direito.

A terceira vertente, na qual se enquadram MAZEAUD E MAZEAUD, ${ }^{133}$ caracteriza-se por refutar a teoria clássica e seus postulados. A referida teoria mantémse personalista, em grau mais atenuado. A teoria defende, ainda, os princípios da unicidade, indivisibilidade, inalienabilidade e inerência do patrimônio à pessoa. A terceira vertente admite a existência de patrimônios de afetação, destinados à realização de um escopo, e classifica o patrimônio como uma universalidade de direito. ${ }^{134}$

A quarta corrente, na qual se enquadra FERRARA, ${ }^{135}$ aproxima-se da terceira por conscientemente repudiar os princípios e métodos clássicos e por manter-se personalista, já que não admite patrimônio sem sujeito. No entanto, o patrimônio não é visto como uma universalidade de direito, de modo que as dívidas não o integram, mas sim o oneram. De acordo com esta teoria, o patrimônio somente constituirá universalidade de direito, abrangendo o passivo, quando a lei criar núcleos patrimoniais afetados a um determinado escopo. ${ }^{136}$

\footnotetext{
${ }^{132}$ BIANCHI, Francesco Saverio. Corso di codice civile italiano. v. IX. Torino: Unione Tipografico, 1895. p. 7.

${ }^{133}$ MAZEAUD, Henri; MAZEAUD, León; MAZEAUD, Jean. Leçons de Droit Civil. 3. ed. tomo I. Paris: Éditions Montchrestien, 1955. p. 111.

${ }^{134}$ Pontes de Miranda parece se filiar a esta terceira concepção da teoria do patrimônio. Isso porque o renomado autor defende a possibilidade de existência de patrimônios separados. (PONTES DE MIRANDA, Francisco Cavalcanti. Op. cit., p. 368).A respeito do posicionamento de Pontes de Miranda, vide ainda PENTEADO, Luciano de Camargo. Princípios em Pontes de Miranda, patrimônio e patrimônios - um legado para o direito privado. In: GORGA, Érica; PELA, Juliana Krueger (Coords.). Estudos avançados de direito empresarial: contratos, direito societário e bancário. São Paulo: Campus, 2012. p. 1-34.

${ }^{135}$ FERRARA, Francesco. Trattato di diritto civile italiano. v. 1. Roma: Athenaeum, 1921. p. 865.

${ }^{136}$ No direito brasileiro, Cassio M. C. Penteado Jr. parece entender que a quarta concepção da teoria do patrimônio é a mais adequada. In verbis: “(...) interessante conotação de Ruggiero, que observa - com precisão, a nosso ver - que, dada a possibilidade do patrimônio separado, este, na verdade, é que constituiria uma espécie de universitas, e não, na forma tradicional, o patrimônio geral. (PENTEADO JR., Cassio M. C. A afetação do patrimônio especial como exceção ao princípio de sua universalidade -
} 
A quinta concepção inova ao admitir patrimônios sem sujeitos. Esta teoria é considerada objetivista, já que admite a existência de patrimônio sem titular e exclui a necessidade de sujeito de direito relacionado ao patrimônio. Diversas linhas doutrinárias podem vir a ser consideradas alinhadas a esta concepção, a saber: as que conduzem às construções dos patrimônios sem sujeito, patrimônios sem dono, patrimônios-sujeitos de direito, patrimônios cujos sujeitos de direito são fins.

A sexta concepção, de DUGUIT, ${ }^{137}$ prega a objetivação absoluta do patrimônio. Funda-se na abolição do conceito de direito subjetivo, que passa a ser categoria inútil. Patrimônio, segundo tal corrente, constituiria um conjunto de riquezas não de direitos - afetas a um fim. E, esta afetação a um fim é soberano e absoluto e não depende de se recorrer a um sujeito com titularidade sobre determinado bem.

A menção, ainda que superficial, das referidas teorias é importante para os fins deste Capítulo.

Isto porque as teorias personalistas, dentre as quais se inclui a teoria clássica de AUBRY E RAU, defendem que o patrimônio é emanação da personalidade e, portanto, tem como base o princípio da unidade - segundo o qual a cada pessoa só corresponde um patrimônio - e que parece ser incompatível com a possibilidade de segregação patrimonial e, portanto, com a existência de patrimônios separados e/ou autônomos.

É evidente, portanto, que esta corrente constitui um óbice ao reconhecimento de patrimônios separados, pertencentes a uma só pessoa. Ocorre que as teorias personalistas mais extremadas podem prejudicar a atividade comercial. Isto porque uma pessoa física ou jurídica pode atuar em diversas áreas e seria um fator de estímulo ao desenvolvimento destas atividades o isolamento de bens e dívidas correspondentes a cada uma delas.

conteúdo jurídico e efeitos. Revista de Direito Bancário, do Mercado de Capitais e da Arbitragem, n. ${ }^{\circ}$ 16, ano 5, São Paulo, RT, abr.- jun. 2002, p. 102-111. p. 43).

${ }^{137}$ DUGUIT, Léon. L'autonomie de la volonté. Les transformations générales du droit privé depuis le Code Napoléon. Paris: Librairie Félix Alcan, 1912. p. 8-20. 
Pela análise das teorias descritas acima, de forma sucinta, percebe-se que somente a partir da terceira concepção é admitida a coexistência de mais de um patrimônio pertencente a uma só pessoa.

SYLVIO MARCONDES, ${ }^{138}$ sob a égide do Código Civil de 1916, já concluía que o direito brasileiro seguia a terceira concepção, a qual admite a existência de pluralidade de patrimônios pertencentes a um mesmo sujeito e que classifica o patrimônio como universalidade de direito.

Para justificar a conclusão, SYLVIO MARCONDES mencionou as seguintes previsões constantes na legislação brasileira:

(i) responsabilização de todos os bens do devedor por suas dívidas; (ii) normas que livram os herdeiros de responder por encargos superiores às forças da herança e a mesmo tempo determinam que a herança responda pelo pagamento das dívidas do falecido.

O advento do Código Civil de 2002 corroborou a conclusão exposta acima, no sentido de que o direito brasileiro é filiado à terceira concepção das teorias do patrimônio.

Isso porque o artigo 91 do Código Civil de 2002 define o conceito de universalidade de direito como "o complexo de relações jurídicas, de uma pessoa, dotadas de valor econômico".

Conforme se depreende da análise do art. 91 do Código Civil de 2002, o conceito de universalidade de direito tem estreita ligação com a "pessoa".

Assim, as regras do Código Civil de 2002 a respeito de responsabilidade patrimonial também corroboram a filiação do direito brasileiro à terceira vertente das teorias do patrimônio. Isto porque a legislação pátria, ao mesmo tempo que vincula o patrimônio a uma "pessoa", também admite exceções de afetação patrimonial, nas quais uma mesma pessoa é titular de patrimônio geral e de patrimônio de afetação destinado a um determinado fim.

\footnotetext{
${ }^{138}$ MARCONDES, Sylvio. Do objeto de direito: patrimônio. Problemas de Direito Mercantil, São
} Paulo, Editora Max Limonad, 1970. p. 88. 
Portanto, no Brasil, a correlação entre patrimônio e personalidade diz respeito somente à titularidade.

Assim, uma pessoa tem aptidão para adquirir situações jurídicas ativas valoráveis em dinheiro e, portanto, a ser titular de patrimônio. No entanto, o ordenamento jurídico brasileiro permite a existência de mais de um patrimônio por pessoa - patrimônio geral ao lado de patrimônios de afetação.

\section{IV.2 Classificação jurídica do patrimônio no direito brasileiro}

Este item analisará a classificação jurídica do patrimônio. Para tanto, será necessário abordar os conceitos de universalidade de direito e de universalidade de fato. $^{139}$

O Código Civil de 1916 previa, em seu artigo 57, que “o patrimônio e a herança constituem coisas universais, ou universalidade, e como tais subsistem, embora não constem de objetos materiais". Portanto, o Código Civil de 1916 era expresso ao mencionar que o patrimônio deveria ser classificado como universalidade.

\footnotetext{
139 Antes de adentrar no conceito de universalidade de direito e de universalidade de fato, é importante tecer determinadas considerações a respeito do conceito de universalidades. Inocêncio Galvão Teles, em sua obra "Das Universalidades", prevê que a universalidade de direito traduz unificação do conjunto, que passa a ter relevância jurídica em si mesmo, formando centro autônomo de imputação objetiva sem que, por outro lado, suas partes percam autonomia. Assim, o titular da universalidade pode estabelecer relações jurídicas pertinentes aos elementos que a compõe, individualmente considerados, sendo até mesmo possível subtraí-los da universalidade. De outro lado, o titular da universalidade pode adquirir novos elementos, que passarão a integrar a universalidade. Assim, a universalidade seria maleável. (TELES, Inocêncio Galvão. Das universalidades. Lisboa: Minerva, 1940. p. 70 e ss).

Conforme Sylvio Marcondes, as universalidades são constituídas por uma pluralidade de coisas, que conservam sua autonomia funcional mas são unificadas em vista de uma particular valorização, feita pelo sujeito ou reconhecida pelo direito. (MARCONDES, Sylvio. Problemas de direito mercantil... cit., p. 75). A respeito da distinção entre universalidade de fato e universalidade de direito, Sylvio Marcondes explica que universalidade de fato pode ser assim caracterizada: (i) trata-se de um conjunto de coisas autônomas, simples ou compostas, materiais ou imateriais; (ii) é formada pela vontade do sujeito; (iii) serve para uma destinação unitária. Já a universalidade de direito: (i) é um complexo de relações jurídicas ativas e passivas; (ii) é formada por força da lei; (iii) serve para unificação das mesmas relações. Assim, a universitas juris é um conjunto de direitos (relações ativas e passivas), enquanto a universitas facti é um conjunto de objetos de direito (Idem, p. 79, 81 e 83).
} 
O Código Civil de 2002, no entanto, não seguiu a mesma estrutura no que se refere à classificação de patrimônio e, portanto, não prevê expressamente que o patrimônio constitui universalidade de direito.

O artigo 90 do Código Civil de 2002 prevê que constitui universalidade de fato a pluralidade de bens singulares que, pertinentes à mesma pessoa, tenham destinação unitária ${ }^{140}$.

Por sua vez, o parágrafo único do referido artigo prevê que os bens que formam essa universalidade podem ser objeto de relações jurídicas próprias.

O conceito de universalidade de direito está previsto no artigo 91 e foi definido no sentido de que constitui universalidade de direito o complexo de relações jurídicas, de uma pessoa, dotadas de valor econômico.

Assim, não há previsão expressa, no Código Civil de 2002, no sentido de que o patrimônio constitui universalidade de direito.

Há controvérsias doutrinárias a respeito da correta classificação do patrimônio. No entanto, apesar do Código Civil de 2002 não mencionar expressamente que patrimônio deve ser caracterizado como universalidade de direito, os elementos descritos no artigo 91, do referido diploma legal, e que caracterizam universalidades de direito são plenamente aplicáveis ao patrimônio e, portanto, são capazes de permitir a classificação do patrimônio como universalidade de direito.

Determinados juristas, dentre os quais se destaca NORONHA, ${ }^{141}$ defendem que existe uma identidade entre os conceitos de universalidade de direito e patrimônio, até porque a herança, classicamente reputada como universalidade de direito, constitui, na sua visão, também uma espécie de patrimônio.

\footnotetext{
${ }^{140}$ Disponível em: <www.planalto.gov.br>. Acesso em: 11 nov. 2013.

141 NORONHA, Fernando. Patrimônios especiais - sem titular, autônomos e coletivos. Revista dos Tribunais n. ${ }^{\circ}$ 747, ano 87, São Paulo, RT, jan. 1998, p. 11-34.
} 
O caráter que unifica o patrimônio de forma a classificá-lo como universalidade de direito tem como premissa a responsabilidade patrimonial, bem como o fato de que sua destinação diz respeito ao alcance dos objetivos econômicos da pessoa física ou jurídica.

Conforme preceitua OLIVA, ${ }^{142}$ o legislador pátrio se posicionou em pelo menos três problemas suscitados pelos doutrinadores que buscam estudar o patrimônio, a saber:

(i) o reputa universalidade de direito; (ii) ao determinar que é formado por relações jurídicas não autoriza o entendimento de que o patrimônio é composto por riquezas ou pelos objetos dos direitos; (iii) ao preceituar que as relações jurídicas são dotadas de valor econômico afasta o entendimento segundo o qual os chamados direitos da personalidade comporiam o patrimônio.

Pelas razões expostas acima, é possível afirmar que o patrimônio deve ser classificado como universalidade de direito.

\section{IV.3 Conceito de patrimônio}

A doutrina majoritária defende que o patrimônio é constituído por relações jurídicas ativas e passivas de caráter econômico. ${ }^{143}$

Assim, o conceito de patrimônio envolve o complexo das relações jurídicas de uma pessoa que tiverem valor econômico. O patrimônio, desta forma, é integrado tanto por elementos ativos quanto por elementos passivos. ${ }^{144}$

\footnotetext{
${ }^{142}$ DONATO, Milena Oliva. Op. cit., p. 118.

${ }^{143}$ Para Oscar Barreto Filho: “A ideia predominante no conceito de patrimônio, seja qual for a concepção adotada, é a de massa de responsabilidade. (...) Independentemente da fonte convencional ou legal da obrigação, o patrimônio do devedor constitui a garantia comum dos credores." (BARRETO FILHO, Oscar. Teoria do estabelecimento comercial: fundo de comércio ou fazenda mercantil. 2. ed. São Paulo: Saraiva, 1988. p. 51).

${ }^{144}$ Conforme BEVILAQUA, Clóvis. Teoria geral do direito civil. 2 ed. Rio de Janeiro: Editora Rio, 1980. p. 168 e PEREIRA, Caio Mario da Silva. Instituições de direito civil. 19. ed. Rio de Janeiro: Forense, 2001, p. 251. É importante mencionar, no entanto, que há autores que defendem que o passivo não pertence ao patrimônio. Neste sentido, vide: LARENZ, Karl. Derecho civil - parte general. Tradução espanhola de IZQUIERDO Y MACIAS-PICAVEA, Miguel. Madri: Editorial Revista de Direito Privado, 1978, p. 405-406. p. 407. E também Inocêncio Galvão Teles (TELES, Inocêncio Galvão. Op. cit., p. 70 e ss). Para referidos doutrinadores o fato de que o patrimônio constitui garantia dos
} 
O Código Civil de 2002 não contem previsão expressa a respeito do conceito de patrimônio.

Não obstante o fato de inexistir previsão legal a respeito do conceito de patrimônio, é cristalino que fazem parte do patrimônio apenas direitos ou relações jurídicas e nunca os objetos de direito propriamente ditos. ${ }^{145}$

Este é o entendimento de PONTES DE MIRANDA: uma casa, em estrita linguagem jurídica, não integra o patrimônio de ninguém, ao contrário, o direito de propriedade sobre a casa ou a posse sobre a casa integram o referido patrimônio. ${ }^{146}$

Assim, economicamente - e também do ponto de vista contábil - o patrimônio é dado como sendo o ativo, subtraído o passivo, enquanto que juridicamente o patrimônio é a soma das relações jurídicas entre o ativo e o passivo.

\section{IV.4 Espécies de patrimônio}

Conforme exposto acima, os doutrinadores criaram o conceito universalidade patrimonial para viabilizar o alcance de determinados objetivos, especialmente para garantir a premissa de que o patrimônio geral é a garantia comum

credores faz com que não faça sentido as dívidas integrarem o patrimônio, assim como também não faz sentido a inclusão de direitos não passíveis de excussão pelos credores no âmbito do patrimônio.

${ }^{145}$ Conforme HILDEBRAND, Lucas Fajardo Nunes. Patrimônio, Patrimônio Separado ou Especial, Patrimônio Autônomo. In FRANÇA, Erasmo Valladão Azevedo e Novaes (Coord.). Direito Societário Contemporâneo I. São Paulo: Quartier Latin, 2009. p. 268.

É importante mencionar que há discussão a respeito da eventualidade de os bens futuros integrarem o patrimônio. A origem dessa discussão advém do quanto previsto no artigo 591 do Código de Processo Civil, segundo o qual "o devedor responde, para o cumprimento de suas obrigações, com todos os seus bens presentes e futuros, salvo as restrições estabelecidas em lei”. A posição doutrinária dominante é no sentido de que o referido dispositivo legal deve ser interpretado de forma que todos os bens presentes integrantes do patrimônio do devedor - ainda que adquiridos posteriormente à constituição do crédito (futuros), respondem pelo inadimplemento do devedor.

${ }^{146}$ Para o referido autor: "Não há domínio do patrimônio, no sentido em que há domínio do bem imóvel, ou do bem imóvel corpóreo, mas o patrimônio é tido como bem incorpóreo, transcendente aos bens corpóreos e incorpóreos que o compõem e nesse sentido é suscetível de ser objeto de direito de propriedade, que é correspondente ao de domínio a titularidade de qualquer direito sobre bem incorpóreo (propriedade intelectual, propriedade industrial). (PONTES DE MIRANDA, Francisco Cavalcanti. Op. cit., p. 352). 
dos credores. No patrimônio geral, portanto, os elementos unem-se pela relação subjetiva comum com a pessoa.

No entanto, a doutrina moderna e o fato de o legislador brasileiro ter se filiado à terceira concepção das teorias do patrimônio permite afirmar que é possível agregar os elementos integrantes de uma universalidade de direito pela sua destinação comum.

Assim, o vínculo entre o sujeito e o seu patrimônio passa a ser objetivo e o patrimônio passa a ser o conjunto de bens coesos pela afetação a um fim econômico determinado.

A partir desta teoria, admite-se a quebra do princípio da unidade e indivisibilidade e a admissão de um patrimônio geral e de patrimônios especiais de titularidade de uma mesma pessoa. ${ }^{147}$

Convém ressaltar, no entanto, que não se admite a pluralidade de patrimônios de uma mesma pessoa, já que isso poderia ensejar a fraude contra credores e a fraude à execução. Assim, a afetação do patrimônio não implica na cisão de patrimônio, mas sim no destaque de parte das relações jurídicas para fim de atingir determinada função.

\footnotetext{
${ }^{147}$ Conforme GOMES, Orlando. Introdução ao direito civil. 12. ed. Rio de Janeiro: Forense, 1997. p. 203.

E, ainda, preceitua Sylvio Marcondes: O trajeto percorrido no campo da teoria do objeto de direito, apreciando a conceituação dos bens que o constituem; sua classificação e o posto ocupado pelas universalidades; a natureza e a distinção a universitas facti e da universitas iuris; as diferentes concepções do patrimônio; posição escolhida, entre elas, pelo legislador brasileiro; a ocorrência de separação patrimonial; estrutura e natureza do patrimônio separado - leva a admitir a viabilidade da criação, em termos de eficácia jurídica, de patrimônio comercial desmembrado do patrimônio geral do comerciante. Incontroverso, como é que a universalidade de direito constitui um complexo de relações jurídicas ativas e passivas, formado por força de lei para unificação das mesmas relações, o patrimônio separado, por sua estrutura caracterizada páginas atrás, havia de enquadrar-se nessa categoria dos objetos de direito. E isso é indubitável, quer atribuísse o legislador, como atribuiu, a mesma natureza ao patrimônio geral, quer não atribuísse. Apartado do patrimônio geral para realizar um determinado fim, o patrimônio separado concentra, em si, o ativo e o passivo emergentes do complexo de relações jurídicas necessárias á satisfação desse fim. A despeito disso, objeto de direito submetido ao poder do sujeito, continua a gravitar, como um satélite, na órbita do titular. Configura-se, portanto, o patrimônio separado como base objetiva apropriada para receber, em direito constituendo, a construção jurídica de instituto, que, propicio à demarcação de uma área patrimonial, permita limitar-se a extensão da responsabilidade. Aliás, tem esse sentido o rumo evolutivo do problema. (MARCONDES, Sylvio. Qualificação e classificação das sociedades. Problemas de Direito Mercantil, São Paulo, Max Limonad, 1970, p. 163-181. p)
} 
A utilidade prática da afetação patrimonial consiste em destacar determinadas relações jurídicas para determinados fins e também para segregar determinado núcleo de relações jurídicas a determinados credores.

\section{IV.5. Definição dos conceitos de patrimônio de afetação, patrimônio separado, patrimônio especial e patrimônio autônomo}

Os patrimônios de afetação, separados, especiais e autônomos, assim como o patrimônio geral, possuem características comuns, dentre as quais é possível destacar:

(i) constituem universalidades de direito;

(ii) são compostos por relações jurídicas suscetíveis de apreciação pecuniária;

(iii) não abrangem os bens futuros e os chamados direitos de personalidade;

(iv) têm como sujeito o titular das relações jurídicas que o compõem.

No entanto, é preciso delimitar cada um dos conceitos para a correta utilização de cada uma das expressões.

As nomenclaturas "patrimônio especial" ou "patrimônio separado", "segregado", "destacado" ou "destinado" são sinônimos que servem para identificar o núcleo patrimonial pertencente a uma determinada pessoa e que convive com o patrimônio geral da referida pessoa.

SALOMÃO FILHO ${ }^{148}$ entende que a definição de "patrimônio separado" é equívoca, já que é utilizada para identificar diferentes conceitos. Uma primeira utilização da expressão é para identificar massas patrimoniais que ficam sujeitas a um regime distinto dos demais componentes do patrimônio de uma pessoa, como por exemplo, no caso do dote e de bens de cônjuges em comunhão.

\footnotetext{
${ }^{148}$ SALOMÃO FILHO, Calixto. O novo direito societário. 4. ed. rev. ampl. São Paulo: Malheiros, 2011. p. 213.
} 
Segundo o professor SALOMÃO FILHO: ${ }^{149}$

\begin{abstract}
a expressão patrimônio especial pode ainda ser utilizada no sentido mais comum que de alguma forma vincula a expressão à limitação de responsabilidade. (...) deve-se dizer de alguma forma, pois limitação de responsabilidade tem por sua vez vários sentidos. Pode significar impossibilidade de responsabilizar o patrimônio separado pelas dívidas de seu titular (é o caso do bem de família, por exemplo). Pode ainda significar que os credores por dívidas oriundas dos bens separados não terão acesso aos bens de seu titular (é o caso do espólio em relação ao herdeiro). Pode por fím significar ambas as coisas, ou seja, a limitação em ambos os sentidos. (...) A separação patrimonial instrumental a essa afetação é exatamente aquela que permite ao comerciante limitar o seu risco (impedindo que dívidas oriundas da atividade comercial ameacem seu patrimônio pessoal) e garante aos credores por dívidas oriundas da atividade praticada com o patrimônio separado (assegurando que aquele patrimônio é a garantia de sua dívida e que, portanto, eles não terão a concorrência dos credores particulares do titular do patrimônio). Nesse sentido é normalmente entendida a expressão patrimônio separado.
\end{abstract}

Já a nomenclatura "patrimônio autônomo" é normalmente utilizada para designar o patrimônio da pessoa jurídica, que é autônomo aos patrimônios de seus sócios.

Há quem confira à expressão "patrimônio autônomo" utilização semelhante à normalmente utilizada para "patrimônios especiais" ou "patrimônios separados" e, portanto, nestes casos, as expressões são utilizadas como sinônimos. No entanto, há críticas doutrinárias a essa última forma de utilização da expressão "patrimônio autônomo".

SYLVIO MARCONDES ${ }^{150}$ traz distinções entre os referidos conceitos ao mencionar que o patrimônio autônomo constitui o patrimônio de uma nova pessoa e, ainda, que o patrimônio autônomo está no plano dos sujeitos, enquanto que o patrimônio especial estaria no plano dos objetos.

\footnotetext{
${ }^{149}$ Idem, ibidem.

150 MARCONDES, Sylvio. Problemas de direito mercantil... cit. p. 95. No mesmo sentido, vide FRANÇA, Erasmo Valladão Azevedo e Novaes. A sociedade em comum. São Paulo: Malheiros, 2013. p. 146. No mesmo sentido vide também BARRETO FILHO, Oscar. Teoria do estabelecimento comercial... cit., p. 57-58. No mesmo sentido, ainda, MARCONDES, Sylvio. Limitação da responsabilidade de comerciante individual. Monografia para o Concurso à Cátedra de Direito Comercial da Faculdade de Direito da Universidade de São Paulo, 1956, p. 234.
} 
Ainda, há discussão a respeito da utilização das expressões "patrimônio separado" e "patrimônio de afetação". Há quem defenda que "patrimônio de afetação" é gênero do qual "patrimônio separado" e "patrimônio autônomo" são espécies. ${ }^{151}$

Para os fins desta dissertação, o patrimônio de afetação será considerado como conceito amplo, do qual o patrimônio especial (ou destacado, separado, segregado, destinado) e o patrimônio autônomo são espécies.

Ainda, este estudo filiar-se-á aos conceitos preconizados por SYLVIO MARCONDES a respeito da definição das expressões "patrimônio especial" e "patrimônio autônomo".

Assim, o item seguinte estará restrito ao conceito, à estrutura e à natureza do patrimônio especial já que, conforme se verificará abaixo, o patrimônio das sociedades em conta de participação foi, a nosso ver e à luz das definições acima expostas, corretamente classificado pelo Código Civil de 2002 como "patrimônio especial".

\section{IV.6 Conceito, estrutura e natureza do patrimônio separado ou especial}

Este item pretende analisar o conceito e principais características do patrimônio especial.

Conforme já explicitado, o patrimônio separado ou especial é aquele que se destaca do patrimônio geral para satisfazer um fim específico.

Nos casos em que a lei determina a criação de patrimônio especial, o titular deve sempre agir no sentido de executar as finalidades para as quais o patrimônio

${ }^{151}$ Conforme ULHOA COELHO, Fabio. A falência de empresário titular de patrimônio separado. Direito Processual Empresarial (Estudos em Homenagem a Manoel de Queiroz Pereira Calças). São Paulo: Campus, 2012. p. 302. Ainda de acordo com referido autor, no caso do "patrimônio autônomo", o patrimônio de afetação se faz acompanhar da alienação para um novo sujeito de direito. É o caso da instituição de fundação, em que o instituidor afeta os bens que transfere ao patrimônio fundacional, vinculando sua administração e frutos à realização de determinadas finalidades. Já no caso do "patrimônio especial", o referido autor entende que não há alienação dos bens afetados a um novo sujeito de direito, já que eles permanecem sob a titularidade do mesmo proprietário que instituiu a afetação, mas passam a compor um patrimônio apartado. 
especial foi criado. Nesta hipótese, portanto, o titular do patrimônio não possui discricionariedade para administrar e dispor do patrimônio especial.

A administração dos bens que compõe o patrimônio especial pode ser atribuída a terceiros ou ao próprio titular do patrimônio geral. Nesta última hipótese, a separação patrimonial é menos visível, mas o titular do patrimônio especial deve administrá-lo com vistas a alcançar a discriminação do patrimônio e o fim a que ele se destina, sob pena de responsabilização.

A segregação patrimonial pode ocorrer por diversas razões: pode ocorrer para satisfazer, de modo preferencial ou exclusivo, um grupo determinado de credores, por exemplo, como ocorre na herança. Outras vezes, permite a destinação de patrimônio a determinadas relações jurídicas ou a determinado sucessor, como é o caso do fideicomisso.

A separação patrimonial também pode ocorrer em determinados regimes matrimoniais como, por exemplo, o regime de comunhão parcial de bens, por meio do qual determinados bens passam a ser comuns ao casal enquanto os bens e/ou frutos de outros bens permanecerem sob a titularidade de apenas um dos cônjuges.

Há ainda outras modalidades de separação patrimonial e, inclusive, as hipóteses de administração de bens de menores, sendo certo que parte da administração pode ser executada por pais e parte por curador.

É importante ressaltar que o titular de patrimônios distintos - geral e especial - somente pode proceder com a compensação de créditos e débitos alocados em um mesmo tipo de patrimônio. Assim, somente pode ocorrer compensação entre créditos e débitos do patrimônio geral ou entre créditos e débitos do patrimônio especial. Não é possível compensar, por exemplo, créditos do patrimônio geral com débitos do patrimônio especial.

Não obstante o exposto acima, é possível estabelecer relações entre o patrimônio geral e o patrimônio especial. Como por exemplo, o patrimônio geral do 
herdeiro pode ser devedor do patrimônio especial da herança em razão, por exemplo, da locação de um imóvel do espólio.

E, ainda, convém destacar que a classificação da separação patrimonial pode ser: perfeita/absoluta ou imperfeita/relativa.

$\mathrm{Na}$ hipótese de separação patrimonial imperfeita/relativa, caso os bens do patrimônio especial não sejam suficientes para a satisfação dos credores que lhes são pertinentes, estes podem excutir os bens integrantes do patrimônio geral.

Já na hipótese de separação patrimonial perfeita/absoluta, o patrimônio geral não possui responsabilidade subsidiária e não pode ser atingido caso os bens do patrimônio especial não sejam suficientes para garantir os correspondentes credores.

Tendo em vista a regra geral da unicidade e indivisibilidade do patrimônio, a criação de patrimônio especial necessita de lei e, portanto, as hipóteses de existência de patrimônio especial são taxativas e serão tratadas abaixo. ${ }^{152}$

Logo, a lei pode discernir dentro da universalidade patrimonial, determinadas circunstâncias em que o patrimônio é separado ou distinto daquela unidade que o define.

SYLVIO MARCONDES ${ }^{153}$ frisa que o tema da afetação de patrimônio guarda nítida relação com o tema de limitação de responsabilidade. Isso porque o problema do valor jurídico dos patrimônios separados interessa, sobretudo, em relação

\footnotetext{
${ }^{152}$ Fabio Ulhoa Coelho entende que a taxatividade restringe-se à afetação do patrimônio no modo "separado", já que, em relação ao modo "autônomo" (vale dizer, a instituição de fundação), os sujeitos de direito têm ampla liberdade, podendo praticar o negócio jurídico correspondente a qualquer tempo, independente de específica autorização legal. A diferença de tratamento justifica-se porque o patrimônio autônomo é titulado pelo sujeito de direito constituído simultaneamente à afetação, de modo que não se escapa à regra geral da unicidade e indivisibilidade. A fundação, como pessoa jurídica, no momento de sua constituição, é titular de um só patrimônio, inconfundível com o do instituidor. (ULHOA COELHO, Fabio. A falência de empresário titular... cit., p. 305.)

${ }^{153}$ MARCONDES, Sylvio. Problemas de direito mercantil... cit., p. 97. No mesmo sentido, FERREIRA, Renato Luis Bueloni. Ensaio sobre a sociedade unipessoal no direito brasileiro e no direito estrangeiro. (Dissertação de Mestrado). São Paulo: Universidade de São Paulo, Faculdade de Direito, 2001. p. 49-61. E também FILÓCOMO, André. Empresas e sociedades unipessoais no direito brasileiro. (Dissertação de Mestrado). São Paulo: Universidade de São Paulo, Faculdade de Direito, 2000.
} 
aos credores do sujeito, titular dos patrimônios. E, a tal propósito, salientando a utilidade prática da criação de um patrimônio separado, assinala a de ser possível reservar-se, para certo grupo de credores, determinado núcleo de bens, sobre o qual possa ser satisfeito, com exclusão de outros credores. Por essas e outras considerações, pondera o autor que o conceito de patrimônio separado apresenta nexo com o de universalidade e com o problema de responsabilidade limitada.

A afetação do patrimônio submete-se às mesmas restrições impostas à alienação de bens e pode tornar-se ineficaz quando praticada com mecanismos que configurem fraude a credores e fraude à execução.

Ainda, convém destacar que a Lei n. ${ }^{\circ} 11.101$, de 09 de fevereiro de 2005 prevê, em seu artigo 119 , inciso IX, que: ${ }^{154}$

os patrimônios de afetação, constituídos para cumprimento de destinação específica, obedecerão ao disposto na legislação respectiva, permanecendo seus bens, direitos e obrigações separados dos do falido até o advento do respectivo termo ou até o cumprimento de sua finalidade, ocasião em que o administrador judicial arrecadará o saldo a favor da massa falida ou inscreverá na classe própria o crédito que contra ela remanescer. ${ }^{155}$

Assim, quando a falência surpreende empresário que havia separado ativos e passivos de seu patrimônio, para afetá-los a determinada finalidade, uns e outros não são alcançados pela quebra. Os credores, titulares de obrigações separadas, não participam da massa falida subjetiva - estão, portanto, dispensados de habilitação e não devem constar do quadro geral de credores -, assim como os ativos separados tampouco

\footnotetext{
${ }^{154}$ Disponível em: <www.planalto.gov.br>. Acesso em: 11 nov. 2013.

${ }^{155}$ A este respeito, Paulo Salvador Frontini, ainda sob a égide da antiga Lei de Falências (Decreto-Lei n. ${ }^{\circ}$ 7.661/45) emitiu parecer a respeito da adequação de decisão judicial que, após convolação de concordata preventiva em falência, decretou a desconsideração da personalidade jurídica da sociedade e estendeu os efeitos da falência ao sócio da pessoa jurídica e aos bens da empresa individual do referido sócio. O referido autor mencionou que o empresário é titular de dois patrimônios, um o patrimônio comum inerente à sua condição de ser humano, que emana do direito de personalidade, e outro, separado, inerente à atividade econômica organizada, que, mediante inscrição no registro de empresa, se caracteriza pelo capital próprio e pela titularidade de uma empresa. Assim, conclui que a medida judicial somente poderia atingir os bens particulares dos sócios, aqueles que compõem seu patrimônio comum, nunca os bens de seu ativo empresarial, que assume, no vigente direito privado brasileiro, feição de patrimônio separado. (FRONTINI, Paulo Salvador. Empresário. Pessoa natural. Seu patrimônio pessoal e a afetação de bens. Direitos e obrigações à atividade econômica. Separação dessas duas massas patrimoniais por força das normas do Código Civil vigente. In: WALD, Arnoldo (Coord.). Doutrinas Essenciais - Direito Empresarial. v. VI (Recuperação judicial e falência). São Paulo: RT, 2011. p. 619-629).
} 
integram a massa falida objetiva - são, em princípio, insuscetíveis de arrecadação, e sua administração não compete ao administrador judicial. ${ }^{156}$

Entendemos que toda construção jurídica e legislativa a respeito da constituição de patrimônios de afetação contribuem para o desenvolvimento econômico do País, já que permite a segregação de patrimônios para determinado fim e a delimitação de riscos da atividade empresarial.

No entanto, localizamos norma tributária que, de certa forma, esvazia toda a finalidade da constituição de patrimônios especiais. Trata-se do artigo 76 da Medida Provisória n. ${ }^{\circ}$ 2.158-35/2001.

O referido artigo dispõe que: ${ }^{157}$

as normas que estabeleçam a afetação ou a separação, a qualquer título, de patrimônio de pessoa física ou jurídica não produzem efeitos em relação aos débitos de natureza fiscal, previdenciária ou trabalhista, em especial quanto às garantias e aos privilégios que lhes são atribuídos.

E, ainda, o referido dispositivo legal, no parágrafo único, prevê que, para esses fins, permanecem respondendo pelos débitos ali referidos a totalidade dos bens e das rendas do sujeito passivo, seu espólio ou sua massa falida, inclusive os que tenham sido objeto de separação ou afetação.

Entendemos que esta disposição legal esvazia a finalidade e a construção jurídica de patrimônio especial, já que a segregação do patrimônio simplesmente não pode ser oposta perante autoridades fiscais, previdenciárias e trabalhistas e faz com que os empresários busquem outros mecanismos para alcançar a finalidade que poderia ser conferida pela afetação patrimonial ${ }^{158}$ ou, ainda, faz com que a economia popular fique desprotegida.

\footnotetext{
${ }^{156}$ Conforme ULHOA COELHO, Fabio. A falência de empresário titular... cit., p. 302.

${ }^{157}$ Disponível em: <www.planalto.gov.br>. Acesso em: 11 nov. 2013.

${ }^{158}$ No caso de afetação patrimonial para incorporação imobiliária, as partes poderiam, por exemplo, constituir sociedades de propósito específico.
} 


\section{IV.7 Exemplos de afetação patrimonial no direito brasileiro}

Este item analisará de forma sucinta exemplos de patrimônio especial no direito brasileiro. ${ }^{159}$ Antes disso, no entanto, convém traçar determinadas notas a respeito da herança e da massa falida, institutos que também ensejam a afetação patrimonial. ${ }^{160}$

\section{IV.7.1 Herança}

A sucessão mortis causa pode dar-se: (i) a título universal, aos herdeiros, na forma prevista em lei; (ii) a título singular, aos legatários, na hipótese de existência de testamento, ocasião em que há transferência de determinados bens por vontade do de cujus (e não decorrente da lei), sendo certo que há determinadas regras cogentes previstas em lei que não podem ser infringidas pelo de cujus ao instituir o testamento.

A herança é o patrimônio do de cujus e constitui universalidade de direito.

A abertura da sucessão ocorre no momento da morte do de cujus. Conforme previsto no artigo 1784 do Código Civil de $2002^{161}$, aberta a sucessão, a herança transmite-se, desde logo, aos herdeiros legítimos e testamentários. Todavia, a herança não se funde ao patrimônio deste, permanecendo segregada para a solução dos débitos do de cujus e para posterior partilha do resultado líquido entre os herdeiros/legatários.

\footnotetext{
${ }^{159}$ Sylvio Marcondes cita os seguintes exemplos de patrimônios especiais: o dote, os bens particulares dos cônjuges, o fideicomisso, o patrimônio dos sujeitos ao pátrio poder, a massa concursal, o patrimônio das sociedades não personificadas, a herança indivisa e os bens da comunhão conjugal. (MARCONDES, Sylvio. Problemas de direito mercantil... cit., p. 93)

${ }^{160}$ A respeito da afetação patrimonial, é importante mencionar a discussão existente a respeito da natureza jurídica das Empresas Individuais de Responsabilidade Limitada - EIRELI e de patrimônio de afetação vinculado a esse instituto. Neste sentido, vide LYNCH, Maria Antonieta. O patrimônio de afetação e as empresas individuais de responsabilidade limitada. Revista de Direito Mercantil, Industrial, Econômico e Financeiro, n. ${ }^{\circ}$ 148, São Paulo, Malheiros, 1996, p. 100-108.

${ }^{161}$ Disponível em: <www.planalto.gov.br>. Acesso em: 11 nov. 2013.
} 
Diante disto, a herança constitui hipótese de afetação patrimonial instituída pelo ordenamento jurídico brasileiro para o fim de tutelar os interesses dos credores do de cujus e, após a sua satisfação, possibilitar a partilha do saldo positivo, se houver, entre os herdeiros. ${ }^{162}$

Trata-se de hipótese de separação patrimonial perfeita, em que o patrimônio geral não possui responsabilidade subsidiária ao patrimônio especial.

\section{IV.7.2 Massa falida}

A partir da decretação falência, o falido continua com a propriedade dos seus bens, mas perde o direito de disposição e administração dos bens.

Os bens do falido formam um patrimônio apartado para satisfação dos credores.

Os bens passam a ser geridos por administrador nomeado pelo juiz, que deve atuar no sentido de preservar a massa falida e os interesses dos credores, não mais do falido. Portanto, a afetação patrimonial da massa falida tem por objetivo proteger os credores do falido com vista à realização do ativo composto pelos bens do falido para liquidação dos passivos.

\section{IV.7.3 Securitização de créditos imobiliários}

A securitização de créditos imobiliários envolve operação disciplinada pela Lei n. ${ }^{\circ}$ 9.514, de 20 de novembro de 1997, na qual uma determinada pessoa que detém créditos imobiliários os cede para uma sociedade securitizadora. Ato contínuo, a sociedade securitizadora emite Certificados de Recebíveis Imobiliários lastreados nos

${ }^{162}$ Conforme DONATO, Milena Oliva. Op. cit. 
créditos imobiliários a ela cedidos. A sociedade securitizadora distribui os Certificados de Recebíveis Imobiliários no mercado.

Nos termos da Lei n. ${ }^{\circ}$ 9.514/1997, a sociedade securitizadora pode constituir patrimônio segregado para resguardar os créditos imobiliários que lhe foram cedidos e impedir que ações e execuções que envolvam a securitizadora possam atingir tais créditos. A proteção dos créditos imobiliários possui ainda sobremaneira relevância na medida em que lastreiam os Certificados de Recebíveis Imobiliários emitidos e distribuídos pela securitizadora no mercado.

A Lei n. ${ }^{\circ} 9.514 / 1997$ prevê, em seu artigo $11, \S 1^{\circ}$, que:

no Termo de Securitização de Créditos poderá ser conferido aos beneficiários e demais credores do patrimônio separado, se este se tornar insuficiente, o direito de haverem seus créditos contra o patrimônio da companhia securitizadora.

E ainda, o parágrafo $2^{\circ}$ do mesmo artigo prevê que: ${ }^{163}$

uma vez assegurado o direito de que trata o parágrafo anterior, a companhia securitizadora, sempre que se verificar insuficiência do patrimônio separado, promoverá a respectiva recomposição, mediante aditivo ao Termo de Securitização de Créditos, nele incluindo outros créditos imobiliários, com observância dos requisitos previstos nesta seção.

Portanto, trata-se de hipótese de separação patrimonial absoluta/perfeita, salvo se a securitizadora inserir previsão em sentido diverso no Termo de Securitização de Créditos.

\section{IV.7.4 Incorporação imobiliária}

Nos termos do parágrafo único do artigo 28 da Lei n. ${ }^{\circ} 4.591$, de 16 de dezembro de $1964:^{164}$

\footnotetext{
${ }^{163}$ Disponível em: <www.planalto.gov.br>. Acesso em: 20 set. 2013.

${ }^{164}$ Disponível em: <www.planalto.gov.br>. Acesso em: 20 set. 2013.
} 
considera-se incorporação imobiliária a atividade exercida com o intuito de promover e realizar a construção, para alienação total ou parcial, de edificações ou conjunto de edificações compostas de unidades autônomas.

A Lei n. ${ }^{\circ}$ 10.931, de 02 de agosto de 2004, acrescentou os artigos 31-A a 31-F na Lei n. ${ }^{\circ}$ 4.591/1964 para prever a segregação patrimonial facultativa em casos de incorporação imobiliária, de forma que, caso o incorporador assim queira, é possível destacar o patrimônio dos empreendimentos de forma que as dívidas de determinado empreendimento imobiliário não possam atingir os demais empreendimentos imobiliários desenvolvidos pela mesma incorporadora.

Com a afetação patrimonial, os adquirentes dos imóveis ficam mais protegidos na medida em que as intempéries de um determinado empreendimento do incorporador não necessariamente afetarão todos os empreendimentos desenvolvidos pelo mesmo incorporador.

\section{IV.7.5 Fundos de Investimento Imobiliário}

A Lei n. ${ }^{\circ}$ 8.668, de 25 de junho de 1993 instituiu os Fundos de Investimento Imobiliários, sem personalidade jurídica, caracterizados pela comunhão de recursos captados por meio do Sistema de Distribuição de Valores Mobiliários, na forma da Lei $\mathrm{n}^{\circ}$ 6.385, de 7 de dezembro de 1976, destinados a aplicação em empreendimentos imobiliários. $^{165}$

$\mathrm{O}$ artigo $6^{\circ}$ da mesma lei prevê que o patrimônio do fundo será constituído pelos bens e direitos adquiridos pela instituição administradora, em caráter fiduciário. ${ }^{166}$

E ainda, nos termos do artigo $7^{\circ}$, o patrimônio do fundo constitui patrimônio autônomo e destacado dos demais patrimônios da administradora do fundo e, assim, não responde direta ou indiretamente por qualquer obrigação da administradora do fundo de

\footnotetext{
${ }^{165}$ Disponível em: <www.planalto.gov.br>. Acesso em: 20 set. 2013.

${ }^{166}$ Disponível em: <www.planalto.gov.br>. Acesso em: 20 set. 2013.
} 
investimento, além de não integrar a lista de bens e direitos da administradora para efeitos de liquidação judicial ou extrajudicial.

Assim, o patrimônio segregado dos fundos de investimentos imobiliários tem por objetivo evitar que perdas financeiras da administradora do fundo atinjam seus bens, sendo que o retorno do investimento dos quotistas estaria sujeito apenas à performance do empreendimento imobiliário em que houver o aporte de recursos.

\section{IV.7.6 Câmara de Compensação e Liquidação do Sistema Brasileiro de Pagamentos - SPB, disciplinado pela Lei n. ${ }^{\circ} 10.214$, de 27 de março de 2001}

O artigo $5^{\circ}$ da Lei n. ${ }^{\circ} 10.214 / 2001$ prevê que as câmaras e os prestadores de serviços de compensação e de liquidação responsáveis por um ou mais ambientes sistemicamente importantes deverão, obedecida a regulamentação baixada pelo Banco Central do Brasil, separar patrimônio especial, formado por bens e direitos necessários a garantir exclusivamente o cumprimento das obrigações existentes em cada um dos sistemas que estiverem operando. ${ }^{167}$

O patrimônio separado, neste caso, visa assegurar a estabilidade nas operações desenvolvidas pelas câmaras sistematicamente importantes, posto que, para a satisfação das demais obrigações desta entidade financeira, não pode ser expropriado judicialmente o ativo consistente nos títulos da dívida pública federal. ${ }^{168}$

\footnotetext{
${ }^{167}$ Disponível em: <www.planalto.gov.br>. Acesso em: 20 set. 2013.

${ }^{168}$ ULHOA COELHO, Fabio. A falência de empresário titular... cit., p. 309.

A respeito do patrimônio de afetação no novo sistema de pagamentos brasileiro, vide artigo de Luiz Carlos Sturzenegger (STURZENEGGER, Luiz Carlos. A doutrina do "patrimônio de afetação" e o novo sistema de pagamentos brasileiro. Revista de Direito Bancário, do Mercado de Capitais e da Arbitragem, n. ${ }^{\circ}$ 11, ano 4, São Paulo, RT, jan.- mar. 2001, p. 229-244).
} 


\section{IV.7.7 Direitos creditórios do agronegócio}

Também há previsão de patrimônio especial na Lei n. ${ }^{\circ}$ 11.076, de 30 de dezembro de 2004. O artigo 39 do referido dispositivo legal remete aos artigos $9^{\circ}$ a 16 da Lei n. ${ }^{\circ}$ 9.514/1997, que preveem expressamente a possibilidade de constituição de patrimônio especial.

A finalidade da possibilidade de constituição de patrimônio especial neste caso permite a segregação patrimonial da sociedade securitizadora responsável por emitir e distribuir os Certificados de Recebíveis do Agronegócio e, com isso, conferir maior proteção aos empresários que atuam no ramo do agronegócio.

\section{IV.7.8 Sociedades não personificadas}

A afetação do patrimônio também pode ser verificada na sociedade em comum e na sociedade em conta de participação.

Este subitem tratará especificamente da sociedade em comum, já que as principais características do patrimônio especial da sociedade em conta de participação serão analisadas no item IV.8.

A atividade negocial da sociedade em comum pode ser simples ou empresária.

A sociedade em comum não tem personalidade jurídica e o patrimônio separado permanece sob titularidade de seus sócios, em comunhão.

O regime de responsabilidade dos sócios da sociedade em comum segue os ditames do artigo 990 do Código Civil de 2002, que prevê que todos os sócios respondem solidária e ilimitadamente pelas obrigações sociais, excluído do benefício de ordem, previsto no art. 1.024 do mesmo diploma legal, aquele que contratou pela sociedade. 
Assim, leciona o professor FRANÇA ${ }^{169}$ que "se a execução dos bens constantes do patrimônio separado não bastar, os credores poderão agredir, subsidiariamente, o patrimônio de um, alguns ou todos os sócios, segundo as regras das obrigações solidárias. (...) Já o sócio que contratou pela sociedade tem responsabilidade direta, vale dizer, não poderá se valer do benefício de ordem previsto no artigo 1.024 do Código Civil de 2002”.

\section{IV.8 Patrimônio especial da sociedade em conta de participação}

O artigo 994 do Código Civil de 2002 prevê que a contribuição do sócio participante constitui, com a do sócio ostensivo, patrimônio especial, objeto da conta de participação relativa aos negócios sociais. ${ }^{170}$

Inicialmente, convém destacar que o fato de a lei ter designado o fundo social como patrimônio especial corrobora o entendimento já tão discutido de que as referidas sociedades são carentes de personalidade jurídica.

Caso contrário, nos parece que a legislação pátria teria atribuído a designação de patrimônio autônomo, expressão típica para designar patrimônio de um novo sujeito, como ocorre na constituição de pessoas jurídicas.

Isso porque a personificação constitui um novo sujeito de direito capacitado a ser titular de patrimônio, então designado como autônomo por estar desvinculado do patrimônio de seus sócios.

Assim, entendemos que a classificação do fundo social como "patrimônio especial" está acertada, já que as sociedades em conta de participação não têm personalidade jurídica e tem o patrimônio desvinculado do patrimônio dos seus sócios.

\footnotetext{
169 FRANÇA, Erasmo Valladão Azevedo e Novaes. A sociedade em comum. São Paulo: Malheiros, 2013. p. 155.

${ }^{170}$ Disponível em: <www.planalto.gov.br>. Acesso em: 15 mar. 2013.
} 
As sociedades em conta de participação não têm personalidade jurídica e, por essa razão, não contam com patrimônio próprio. O fundo social - cuja composição será tratada adiante -, não é de titularidade da sociedade em conta de participação, mas sim do sócio ostensivo. A este respeito, vide o subitem IV.8.1.

O artigo 994 do Código Civil de 2002 parece restringir a composição do patrimônio especial ao prever que será constituído pelas contribuições dos sócios. No entanto, entendemos que o patrimônio especial também é composto por rendimentos do fundo social, lucros não distribuídos aos sócios, além dos demais recursos relacionados ao objeto da sociedade em conta de participação.

Conforme exposto anteriormente, o patrimônio separado ou especial formase pelo que nele entrou simultaneamente ou após a criação dele, pelo que se adquire em virtude de direito pertencente ao patrimônio ou pelo que se há de sub-rogar àqueles ou a estes elementos, e pelo que se adquire em virtude de negócio jurídico ou ato jurídico stricto sensu, referente ao patrimônio. ${ }^{171}$

Por esta razão, entendemos que o artigo 994 do Código Civil de 2002 deveria prever que o patrimônio especial é formado pela contribuição dos sócios, bem como por todas as relações jurídicas líquidas que vierem a integrar o patrimônio social após a constituição da sociedade, inclusive os rendimentos do fundo social, lucros não distribuídos aos sócios e demais recursos relacionados ao objeto da sociedade em conta de participação. ${ }^{172}$ Convém ressaltar que os passivos devem integrar o patrimônio especial, já que o conceito de patrimônio, conforme já exposto, envolve relações jurídicas ativas e passivas.

O parágrafo $1^{\circ}$ do artigo 994 , por sua vez, dispõe que a especialização patrimonial somente produz efeitos em relação aos sócios.

\footnotetext{
${ }^{171}$ Conforme PONTES DE MIRANDA, Francisco Cavalcanti. Op. cit., p. 371.

${ }^{172}$ A respeito dos aportes dos sócios, é importante mencionar que Tullio Ascarelli analisou a incidência do antigo imposto de sêlo em sociedades em conta de participação. Na ocasião, entendeu que para que haja uma "entrada" dos sócios é necessária a sua transferência do patrimônio de uma pessoa para o patrimônio de outra. Assim, entendeu que não poderia constituir entrada a quota que o sócio gerente aplicasse nas operações em participação, pois, em tal caso, não há passagem dessa quota do patrimônio de uma pessoa para o de outra diversa. Por conseguinte, somente poderiam ser consideradas como entradas da sociedade em conta de participação as quotas com que entram os participantes. (ASCARELLI, Tulio. Sociedade em conta de participação e imposto de sêlo. Ensáios e Pareceres. São Paulo: Saraiva, 1952. p. 360-364).
} 
Sob a égide do Código Comercial, o tema da especialização patrimonial era tratado de forma distinta. O artigo 327 do Código Comercial, já revogado, previa que: ${ }^{173}$

na mesma sociedade o sócio gerente responsabilizava todos os fundos sociais, ainda mesmo que seja por obrigações pessoais, se o terceiro com quem tratou ignorava a existência da sociedade; salvo o direito dos sócios prejudicados contra o sócio gerente.

O artigo 328 do Código Comercial, também revogado, por sua vez, previa:

no caso de quebrar ou falir o sócio gerente, é licito ao terceiro com quem houver tratado saldar todas as contas que com ele tiver, posto que abertas sejam debaixo de distintas designações, com os fundos pertencentes a quaisquer das mesmas contas; ainda que os outros sócios mostrem que esses fundos lhes pertencem, uma vez que não provem que o dito terceiro tinha conhecimento, antes da quebra, da existência da sociedade em conta de participação.

Portanto, a disciplina do patrimônio e, por consequência, a disciplina da responsabilidade nas sociedades em conta de participação, sob a égide do Código Comercial, pode ser esquematizada da seguinte forma:

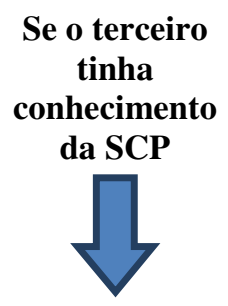

Os fundos sociais só respondem por dívidas da SCP e não podem ser atingidos por dívidas pessoais do sócio gerente.

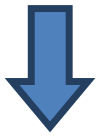

Em caso de quebra do sócio gerente, os fundos da SCP respondem por dívidas da SCP.

\author{
Se o terceiro não \\ tinha conhecimento \\ da SCP
}

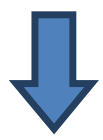

Responsabilização dos fundos sociais, ainda que por obrigações pessoais do sócio ostensivo.

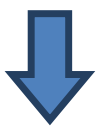

Em caso de quebra do sócio gerente, o fundo social da SCP pode responder por dívidas, inclusive pessoais, do sócio gerente.

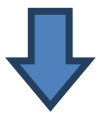

Direito do sócio prejudicado contra o sócio gerente

\footnotetext{
${ }^{173}$ Disponível em: <www.planalto.gov.br>. Acesso em: 15 mar. 2013.
} 
Conforme WALDEMAR FERREIRA, ${ }^{174}$ sob a égide do Código Comercial:

Residia o primacial da estrutura interna da sociedade em não constituir a quota entregue pelo participante, para as operações de sua finalidade, patrimônio específico e próprio. Não o tinha ela. As mercadorias ou produtos, para ela trazidos, agregavam-se ao patrimônio individual do sócio gerente e ostensivo, dominum negotiatione, como se dele, exclusivamente, fossem. Ao seu patrimônio, acresciam, pela própria natureza da sociedade; mas sem atribuir co-propriedade.

Com relação à ressalva do Código Comercial a respeito da ciência dos credores com relação à sociedade em conta de participação, BRANDÃO LOPES ${ }^{175}$ menciona que:

a ressalva existe não para proteger os sócios participantes, mas para proteger os credores da sociedade em conta de participação, em face dos credores do sócio ostensivo que, ao contratar com este, sabiam que os fundos sociais não garantiriam o seu crédito.

Portanto, o Código Comercial admitia a possibilidade dos fundos sociais responderem apenas por dívidas da própria sociedade em conta de participação na hipótese de terceiros particulares do sócio gerente saberem da existência da sociedade em questão.

A referida previsão legal era inócua, já que de difícil execução. A sociedade em conta de participação não é registrada em órgão de registro público e a demonstração a respeito da ciência de terceiros a respeito de sua existência nos parece ser de difícil comprovação. ${ }^{176}$

A disciplina do Código Comercial não foi repetida no Código Civil de 2002. Para este último diploma legal, é indiferente a ciência dos credores particulares do sócio ostensivo quanto à existência da sociedade em conta de participação.

\footnotetext{
${ }^{174}$ FERREIRA, Waldemar. Op. cit., p. 204.

175 LOPES, Mauro Brandão. A sociedade em conta de participação... cit., p. 67-68.

${ }^{176}$ A esse respeito, Pontes de Miranda menciona que o fato de declarar o sócio participante ativo que opera em nome dos outros sócios, ou da sociedade, não vincula os outros sócios, diretamente, nem a sociedade. Para isso seria preciso que os outros sócios consentissem. Declarar que há sociedade em conta de participação não basta para a vinculação. Se o sócio participante ativo faz a declaração e comunica aos sócios participantes inativos, o silêncio desses há de ser tido como consentinte. (PONTES DE MIRANDA, Francisco Cavalcanti. Op. cit., p. 339).
} 
Ao que nos parece, o Código Civil de 2002 trouxe uma disciplina mais adequada a respeito deste tema. Isto porque a sociedade em conta de participação é uma sociedade interna, não oponível a terceiros. A eficácia da sociedade em conta de participação não atinge terceiros.

O Código Civil de 2002 retratou uma nova disciplina para o patrimônio e o regime de responsabilidade nas sociedades em conta de participação ao prever a especialização patrimonial, nos termos do artigo 994 do referido diploma legal.

Portanto, as principais diferenças existentes entre o regime do Código Civil de 2002 e o regime do Código Comercial no diz respeito ao patrimônio das sociedades em conta de participação se referem ao fato de que aquele inovou ao prever a especialização patrimonial e excluiu a diferenciação no que se refere à ciência ou não dos credores com relação à existência da sociedade em conta de participação.

O artigo 994, § $1^{\text {o }}$, do Código Civil de 2002 prevê que a especialização patrimonial somente produz efeitos em relação aos sócios e, portanto, não produz efeitos perante terceiros.

Os credores das sociedades em conta de participação não têm reservado para si o patrimônio especial para execução em caso de inadimplemento. Da mesma forma, os credores particulares do sócio ostensivo e os credores sociais podem perseguir todo o patrimônio do sócio ostensivo, inclusive o patrimônio especial, para satisfação de seu crédito.

ULHOA COELHO ${ }^{177}$ entende que o fato de a especialização patrimonial não produzir efeitos perante terceiros implica a completa inutilidade do instituto, já que a instituição do patrimônio separado somente se justifica para vincular a satisfação de determinados passivos à expropriação de certos bens. Entende ainda o referido autor que melhor teria sido a lei estipular que os bens e obrigações, ativas e passivas, da conta em participação constituiriam um patrimônio separado do sócio ostensivo, nele incluídas as obrigações passivas em face dos sócios participantes (regidas pelo contrato de sociedade).

${ }^{177}$ ULHOA COELHO, Fabio. A falência de empresário titular de patrimônio separado... cit, p. 314. 
Entendemos que a crítica introduzida por ULHOA COELHO deve ser considerada, já que o fato de a especialização patrimonial ser oponível apenas entre os sócios implica a subutilização do instituto, já que realmente a teoria do patrimônio especial, conforme retratado nos itens acima, foi construída para o fim de segregar determinadas relações jurídicas com um fim específico. E, a utilidade prática da criação de um patrimônio separado é, sobretudo, reservar para certo grupo de credores, determinado núcleo de bens, sobre o qual possa ser satisfeito, com exclusão de outros credores.

Por outro lado, a formação de patrimônio especial somente parece fazer sentido se o tratamento especial atribuído à massa patrimonial segregada for oponível a terceiros. Em virtude deste fato, entendemos que a eficácia do patrimônio especial está vinculada à publicidade de sua formação. Para proteger os interesses dos credores, entendemos ser de fundamental importância a publicidade a respeito da existência de patrimônios separados.

Ocorre que a sociedade em conta de participação não está sujeita ao registro em órgãos de registro do comércio e/ou em cartórios. Por essa razão, entendemos que o fato de que os atos constitutivos da sociedade em conta de participação não estarem sujeitos a registro em órgãos competentes faz com que se aumente a dificuldade ou até mesmo se inviabilize a conciliação deste tipo societário com o conceito amplo de patrimônio especial, oponível a terceiros.

Tendo em vista que a sociedade em conta de participação não possui patrimônio próprio e que a especialização patrimonial não pode ser oposta a terceiros, convém avaliar a importância e a finalidade do legislador brasileiro ter inserido previsão no sentido de prever que as contribuições dos sócios constituem patrimônio especial e que a especialização patrimonial diz respeito apenas às relações internas, entre os sócios.

Entendemos que a especialização patrimonial entre os sócios tem a finalidade de delimitar a responsabilidade do sócio ostensivo no que se refere à consecução do objeto social e para responsabilizá-lo em caso de desvio de bens e/ou 
recursos para a realização de outra atividade e/ou finalidade não relacionada com o objeto social. $^{178}$

\section{IV.8.1 Propriedade dos fundos sociais que compõe o patrimônio especial}

Tendo em vista que, conforme exposto em capítulo próprio deste trabalho, a sociedade em conta de participação não possui personalidade jurídica, os fundos sociais não pertencem à sociedade que, portanto, não possui patrimônio próprio.

Este item abordará a polêmica existente acerca da propriedade dos fundos sociais das sociedades em conta de participação.

A questão é polêmica, pois há autores filiados a diversas correntes a este respeito. ${ }^{179}$

\footnotetext{
${ }^{178}$ Neste mesmo sentido SCALZILLI, João Pedro, SPINELLI, Luis Felipe. Reflexões sobre a sociedade em conta de participação... cit., p. 49-58. In verbis: "E, por todo o exposto, a exata individualização do fundo social da conta de participação dentro do patrimônio geral do ostensivo apresenta como principal finalidade impedir a malversação dos bens que o compõem, permitindo que os sócios participantes realizem a devida fiscalização da atuação do ostensivo e que promovam a devida ação de responsabilidade em caso de má administração dos referidos bens. (...) Em contrapartida, aqueles que são destinados ao exercício do objeto social da conta de participação constituem patrimônio especial, ficando, portanto, o sócio ostensivo contratualmente - Direito das Obrigações - vinculado à realização do objeto social com aquele patrimônio especial, podendo ser responsabilizado caso se comprove que desviou os bens e/ou direitos para a realização de outra atividade."

Neste sentido, vide julgado constante em TJSP. Apelação Cível com Revisão n. ${ }^{\circ}$ 002758280.2007.8.26.0114, rel. Romeu Ricupero, j. 06.12.2011.

A este respeito, vide excerto doutrinário interessante, que demonstra a correlação entre patrimônio e responsabilidade dos sócios gerentes nas sociedades comerciais: "Nas sociedades comerciais de mais antiga formação, em que o desenvolvimento de atividades econômicas tinha de suplantar questões de status ou de proibições sociais que atingiam nobres e clérigos, objetivando a proteção da circulação do crédito, verifica-se que o completamento (sic) do contrato estava preso às regras de responsabilidade ilimitada e solidária dos sócios, todos ou alguns, em geral administradores da sociedade. A constrição imposta ao sócio cujo patrimônio poderia ser afetado por decisões relativas ao exercício da atividade servia para impor conduta cautelosa, ao mesmo tempo em que favorecia consultas permanentes entre os membros da sociedade. Ademais disso, o sistema de administração era o do auto-organicismo, isto é, administradores deveriam ser, necessariamente, membros da sociedade. (SZTAJN, Rachel; VERÇOSA, Haroldo Malheiros Duclerc. A incompletude do contrato de sociedade. Revista de Direito Mercantil, Industrial, Econômico e Financeiro, n. $^{\circ}$ 131, São Paulo, Malheiros, 2003, p. 15. p. 15)

${ }^{179}$ Alguns escritores, entretanto, contornando a dificuldade que evidentemente existe, deixam a questão de lado sem resolvê-la; outros preferem não a considerar sequer. Assim, João Eunápio Borges, depois de notar que os fundos "não pertencem à sociedade", considera duas possibilidades, sem se resolver por nenhuma: "Ou são transferidos pelos sócios participantes ao gerente, cujo patrimônio particular se integram, ou são simplesmente confiados por aqueles a este para fins da sociedade, conservando, porém, cada um dos sócios a sua propriedade sobre os bens conferidos." (LOPES, Mauro Brandão. A sociedade em conta de participação... cit., p. 65-66.)
} 
Determinados autores defendem que o patrimônio constituirá uma comunhão entre sócios ostensivos e sócios participantes, isto é, que pertencerá a todos os sócios conjuntamente, tendo nele cada um uma parte pro indiviso. ${ }^{180}$

Outros autores defendem que cada sócio conserva a propriedade de seus aportes.

No entanto, a corrente doutrinária majoritária é no sentido de que os aportes dos sócios passarão a integrar os fundos sociais, de titularidade exclusiva do sócio ostensivo. $^{181}$

Entendemos que a posição doutrinária majoritária é a mais adequada no que se refere à titularidade dos fundos sociais que compõe o patrimônio especial. O sócio ostensivo torna-se titular dos fundos sociais que compõe o patrimônio especial e, em decorrência deste fato, torna-se vinculado a destinar o patrimônio especial para o fim específico para o qual foi constituído, que equivale ao objeto da sociedade em conta de participação.

O titular do patrimônio especial - no caso, o sócio ostensivo - deve sempre agir no sentido de executar as finalidades para as quais o patrimônio especial foi criado.

${ }^{180}$ Neste sentido, vide TJSP, Apelação n. ${ }^{\circ}$ 0046037-57.2009.8.26.0071, rel. Des. Ricardo Negrão, j. 22.07.2013, que menciona que os sócios ostensivo e oculto formam um patrimônio especial, não pertencente à sociedade, e sim aos sócios em condomínio. O referido julgado cita Paulo R. Colombo Arnoldi: "os sócios constituem um capital social para efeitos de distribuição de lucros e pagamento de pró-labore (...). Neste tipo de sociedade, não se constitui a personalidade jurídica, os bens com os quais os sócios ingressam na sociedade não se transferem para ela. Daí, subentender-se que os sócios conservam o domínio sobre os bens, transferindo exclusivamente o proveito destes" (Código Civil Interpretado; organizador Costa Machado; coordenadora Silmara Juny Chinellato; $2^{\mathrm{a}}$ ed., Barueri, Manole, 2009, p. 728, comentário ao art. 994, $\S 1^{\circ}$ ).

${ }^{181}$ No entanto, o referido posicionamento é alvo de críticas. Para Flávio Augusto Picchi "Não nos parece que a propriedade do fundo social passe ao patrimônio do sócio ostensivo; senão sua administração. Mesmo no regime do CC, a responsabilidade dos fundos sociais pelo sócio ostensivo (gerente), ainda que por obrigações pessoais, confere, aos demais sócios, direito contra aquele. Houvesse transferência de patrimônio de uma pessoa a outra, qual seria a contrapartida? No caso, nenhuma, de modo a representar enriquecimento sem causa. E, além disso, como se pode pretender o direito regressivo contra alguém que alienou seu próprio patrimônio? De qualquer forma, o CC parece resolver o problema, ao mencionar "especialização" patrimonial, e não transferência. Além disso, contribuição dos sócios constituir patrimônio especial não é causa de alienação, mas de regime diferenciado de administração.” (PICCHI, Flávio Augusto. A sociedade em conta de participação e os contratos de investimento coletivo: paralelismo e assimetria. Revista de Direito Mercantil, Industrial, Econômico e Financeiro, n. ${ }^{\circ}{ }^{134}$, São Paulo, RT, abr.-jun./2004, p. 195). 
Nesta hipótese, o titular do patrimônio não possui discricionariedade para administrar e dispor do patrimônio especial como bem entender.

Em caso de desvio de finalidade quanto à utilização dos fundos sociais, o sócio ostensivo pode ser responsabilizado. As regras de responsabilização do sócio ostensivo devem ser equiparadas às aplicáveis a administradores de sociedades que agem em desacordo com os deveres de diligência, de lealdade, de informar, de obediência, bem como agem com desvio de poder, nos termos dos artigos 153 e seguintes da Lei das Sociedades por Ações. ${ }^{182}$

$\mathrm{Na}$ maioria das vezes, a contribuição do sócio participante para os fundos sociais da sociedade em conta de participação é feita a título de transferência da propriedade de um bem ou mediante aporte de recursos em moeda corrente nacional, de forma que os bens transferidos/aportados passam a integrar a esfera patrimonial do sócio ostensivo, que fica vinculado à sua obrigação de administração.

No entanto, o sócio participante pode também conservar a propriedade do bem e transferir ao fundo social que compõe patrimônio especial o uso e gozo do referido bem. ${ }^{183}$

\footnotetext{
${ }^{182}$ A respeito disto, Alfredo de Assis Gonçalves Neto afirma que: "O ostensivo age com ampla autonomia nas suas relações com terceiros, mas, perante os seus sócios ocultos, tem os deveres e as responsabilidades do administrador" (GONÇALVES NETO, Alfredo de Assis. Direito de empresa... cit., p. 155).

${ }^{183}$ Conforme Pontes de Miranda: “A contribuição pode ser: a) de bem que fique em comum, ou b) de bem de que não se transfira a propriedade, mas só o direito de uso, e c) de bem de que se transfiram ao sócio participante ativo a propriedade e a posse. Se o participante entra com bem imóvel, é preciso que se transfira a propriedade ao sócio participante gerente, ou que se estabeleça, com as exigências legais, a mancomunhão, porque, se nem aquilo nem isso ocorre, a propriedade continua com o participante, e só se destinam à sociedade o uso e a fruição, ou só o uso, ou só a fruição (PONTES DE MIRANDA, Francisco Cavalcanti. Op. cit., p. 332).

Waldemar Ferreira também admite o aporte de sócio via outorga do direito de uso de bem. Segundo o referido autor, essa situação ocorre nas sociedades em conta de participação para exploração de filmes, fórmulas e inventos. (FERREIRA, Waldemar. Op. cit., p. 518).

De acordo com José Gabriel de Assis Almeida há diferentes regimes aplicáveis à contribuição dos sócios. O primeiro deles - regime da co-propriedade - é aquele em que os sócios colocam as suas entradas em condomínio, escolhendo, entre si, um ou mais para administrá-lo. O segundo regime - da cessão - por meio do qual os sócios conservam a propriedade de suas contribuições, só transferindo a posse ou a detenção dos seus aportes. O terceiro regime - da manutenção da propriedade - por meio do qual os sócios conservam a propriedade, a posse e a detenção daquilo que conferem ao fundo social e simplesmente destacam do seu patrimônio geral uma parcela, que irá constituir patrimônio de afetação, dentro do patrimônio de cada sócio (ALMEIDA, José Gabriel de Assis de. Op. cit., p. 96-100).
} 
É o que ocorre, por exemplo, nos casos em que as sociedades em conta de participação são utilizadas como instrumento jurídico para viabilizar a exploração de flats ou pools hoteleiros. Nestes casos, uma sociedade especializada na administração de bens de terceiros contrata, na condição de sócia ostensiva, uma sociedade em conta de participação com os proprietários de apartamentos e condôminos de um edifício, que se obrigam na qualidade de sócios participantes e que destinam o imóvel de sua propriedade à exploração hoteleira.

A porção do fundo social que cabe aos sócios participantes é integralizada pela transferência, a título de uso, dos apartamentos de sua propriedade, os quais são locados para terceiros pela sócia ostensiva. A sócia ostensiva, por sua vez, contribui com sua expertise na administração de flats e pool hoteleiros, que envolve a aquisição de móveis e equipamentos, a contratação de funcionários, a exploração de serviços de condomínio, bem como a locação das unidades. ${ }^{184}$

A natureza da contribuição do sócio participante é importante, realmente, no caso de sobrevir a falência do sócio ostensivo.

Se a contribuição do sócio participante é realizada a título de transferência de propriedade e/ou aporte de recursos em moeda corrente nacional, o bem participa da norma geral dos bens sujeitos aos efeitos da falência e o crédito do sócio participante constitui crédito quirografário, nos termos do artigo 994, parágrafo $2^{\circ}$, do Código Civil de $2002 .{ }^{185}$

\footnotetext{
${ }^{184}$ Neste sentido vide também GALIZZI, Gustavo Oliva. A sociedade em conta de participação como subespécie do gênero "joint venture". Revista de Direito Mercantil, Industrial, Econômico e Financeiro, n. ${ }^{\circ} 135,2004$, p. 89-90.

${ }^{185}$ A esse respeito, convém mencionar decisão judicial em recurso de agravo de instrumento interposto por Carlos Alberto Schoups contra decisão que negou provimento ao recurso apresentado e que manteve decisão no sentido de arrecadar todas as máquinas que integram no patrimônio de sociedade falida - ESB Eletronic Service Indústria e Comércio Ltda. (Agravada). O Agravante alega que 50\% das máquinas são de sua propriedade, já que constituiu sociedade em conta de participação na qual o agravante participava como sócio oculto e a Agravada participava como sócia ostensiva. Aduz ainda que no ato de constituição a Agravada aportou ao patrimônio da SCP determinadas máquinas, enquanto que o Agravante aportou recursos em moeda corrente nacional e que no decorrer dos anos a SCP passou a ter, dentre seus ativos, 132 máquinas. Em virtude desse fato, o Agravante alega ser proprietário da metade das 132 máquinas, já que sua participação na SCP era de $50 \%$ do patrimônio especial. Destaca que cabia ao Agravante o gerenciamento dos negócios da SCP e que recebia pró-labore em contrapartida a tais serviços. Afirma que a Agravada cedeu sua participação na sociedade para a Flag International e, na sequência, foi decretada a falência da Agravada e foi rescindido de pleno direito o contrato firmado entre Agravante e Agravado. A decisão judicial foi no sentido de afirmar que as 132 máquinas integram o patrimônio da sociedade falida - Agravada - e que, portanto, devem ser arrecadadas em prol da massa falida. A decisão ainda menciona que o Agravante mencionou gerenciar as atividades da SCP e que essa afirmação enseja sua
} 
No entanto, se o sócio participante conservou a propriedade do bem, conferindo apenas o uso ou gozo do bem em questão, a situação é diferente. Nesta hipótese, o sócio participante pode reivindicar o bem não fungível, cuja propriedade reservou-se totalmente. O sócio ostensivo será considerado mandatário, comissário ou depositário de tais bens, e, em quaisquer destas situações, a restituição dos bens é cabível.

Convém analisar, ademais, a natureza dos aportes realizados pelos sócios na sociedade em conta de participação, mais especificamente se é possível conferir serviços ao patrimônio social.

A este respeito, concordamos com PONTES DE MIRANDA, ${ }^{186}$ quando entende que a sociedade em conta de participação tem todo o caminho da contribuição capitalística para contribuição em serviços. As operações participadas consistentes em empréstimos de dinheiro são exemplo do ponto inicial; no meio, temos a sociedade em conta de participação em que o sócio participante ativo dá a pecúnia ou algum bem de que possa ser utilizado por outro ou por outros sócios, que só prestam serviços.

ASCARELLI ${ }^{187}$ também admite que a entrada do sócio pode ser constituída pela sua "indústria", isto é, pela prestação de serviços e, ainda, analisa caso concreto em

responsabilidade solidária pelas obrigações contraídas pela SCP. A decisão menciona ainda que a decretação da falência do sócio ostensivo enseja a dissolução da SCP e consequente procedimento de prestação de contas, razão pela qual o Agravante, se intenta ser merecedor de recebimento de máquinas ou recursos, deve ser considerado credor quirografário, nos termos do art. 994, \$2 e 996 do Código Civil

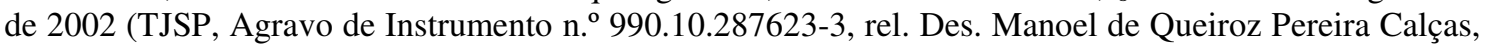
j. 19.10.2010).

O Código Civil de 2002 contém previsão específica a respeito da natureza do crédito de sócios de sociedade em conta de participação no sentido de que os referidos créditos constituem créditos quirografários. Já Lei n. ${ }^{\circ} 11.101$, de 09 de fevereiro de 2005, em seu artigo 83, nciso VIII, prevê que os créditos de sócios são classificados como subordinados. O artigo 994, § $2^{\circ}$ do Código Civil de 2002 não foi alterado a partir da vigência da Lei n. ${ }^{\circ} 11.101 / 05$ e, portanto, entendemos que a classificação específica do Código Civil de 2002 deve prevalecer ao disposto na Lei n. ${ }^{\circ}$ 11.101/05.

${ }^{186}$ PONTES DE MIRANDA, Francisco Cavalcanti. Op. cit., p. 321.

No mesmo sentido Paulo Cavalcanti Salgado, in verbis: "Tudo aquilo que tem valor econômico pode servir de quota nas sociedades em conta de participação: dinheiro, bens, trabalhos, papéis de crédito, clientela, marca de fábrica, privilégio industrial, crédito comercial. (...) Não é necessário que a contribuição para o fundo social se faça em bens da mesma natureza, nem que a parte dos sócios nos lucros e nas perdas obedeça a um igual critério de proporção do valor dos quinhões; nem que haja exata correlação entre os lucros e perdas." (SALGADO, Paulo Cavalcanti. Op. cit., p. 82-83)

${ }^{187}$ ASCARELLI, Tulio. Sociedade em conta de participação... cit., p. 360-364. 
que a prestação do sócio participante consistiu na compra de café por conta e em nome do sócio ostensivo.

Entendemos que, caso o aporte consista em transferência de propriedade de bem imóvel, as partes deverão firmar a escritura pública correspondente. 


\section{CAPÍTULO V SÓCIOS: ADMISSÃO, SAÍdA, PARTICIPAÇÃo NOS RESULTADOS E RESPONSABILIDADE}

\section{V.1 Sócios: espécies, admissão, saída, participação nos resultados}

\section{V.1.1 Espécies de sócios}

Conforme já exposto, a sociedade em conta de participação é formada por dois tipos de sócios: o sócio ostensivo e o sócio participante.

Este item analisará os aspectos relacionados aos sócios da sociedade em conta de participação.

Inicialmente, é importante mencionar que a constituição deste tipo societário exige a participação de dois ou mais sócios, sendo que ao menos um dos sócios deve participar na qualidade de sócio ostensivo.

A obrigatoriedade de participação de ao menos um sócio ostensivo advém da disposição do artigo 991 do Código Civil de 2002, que prevê que a atividade constitutiva do objeto social deve ser exercida unicamente pelo sócio ostensivo.

Não é possível, portanto, a existência de sociedade em conta de participação formada apenas por sócio participante. Essa afirmação é válida, inclusive, para os casos em que o sócio participante tomar parte nas relações com terceiros e, com isso, tornar-se responsável solidário pelas obrigações sociais, nos termos do artigo 993, parágrafo único, do Código Civil de 2002.

Da mesma forma, não é usual a existência de sociedade em conta de participação composta apenas por sócio ostensivo. Isto porque a função deste tipo societário é exatamente conferir um arcabouço jurídico apto a resguardar e regular os negócios em que um dos sócios, o participante, deseja realizar aportes e investimentos e, por algum motivo, não deseja assumir deveres e obrigações perante terceiros. 
Além disto, há outros tipos societários, com previsão de responsabilidade limitada, que podem ser mais adequados aos casos de sociedades contratadas somente entre eventuais sócios ostensivos de uma sociedade em conta de participação.

No entanto, a existência de sociedade em conta de participação composta apenas por sócios ostensivos não é proibida. ${ }^{188}$

Diante disto, nos casos em que, no âmbito de uma sociedade em conta de participação, o(s) sócio(s) participante(s) deseje(m) sair do quadro societário ou, ainda, na hipótese de falecimento do(s) sócio(s) participante(s) [sem ingresso de herdeiros] que enseje a permanência de apenas sócio(s) ostensivo(s) na sociedade, uma opção viável seria dissolver a sociedade em conta de participação, levantar os ativos e liquidar os passivos e, em caso de eventual resultado positivo, distribuir aos sócios na proporção de sua participação na sociedade, conforme estipulado no ato constitutivo. A partir disto, os sócios que participavam como sócios ostensivos poderiam aportar os bens e recursos em uma sociedade limitada ou em uma sociedade por ações, por exemplo.

Não há vedação legal no que se refere à participação de mais de um sócio ostensivo e de mais de um sócio participante. Diante disto, é possível afirmar que a sociedade em conta de participação pode ser formada por um ou mais sócios ostensivos e por um ou mais sócios participantes. ${ }^{189}$

\footnotetext{
${ }^{188}$ A este respeito, Mauro Brandão Lopes menciona que: "Assim, tomo primeiramente a possibilidade de todos os sócios serem ostensivos, cada um com a propriedade de um estabelecimento. Neste caso, os fundos sociais em poder de cada sócio podem ter sido formados por entradas de todos ou alguns dos demais sócios, ou somente pela entrada dele próprio; em outras palavras, as entradas de todos se podem distribuir por todos ou alguns estabelecimentos, ou conservar cada sócio exclusivamente a própria entrada. Tanto numa eventualidade como noutra, é ilimitada, por força de lei, a responsabilidade de cada sócio ostensivo pelas obrigações sociais resultantes dos negócios por êle próprio praticados, e pode ser, quanto às obrigações sociais resultantes dos negócios por cada um dos demais, solidária ou não com os demais sócios, além e ilimitada, ou ilimitada somente quanto à sua parte dos eventuais prejuízos, ou ainda limitada a determinado montante de prejuízos, ou afinal limitada estritamente ao valor de sua quota. (LOPES, Mauro Brandão. Ensaio sôbre a conta de participação... cit., p. 149).

${ }^{189}$ A esse respeito o Professor Erasmo Valladão menciona que: “(...) o Código Civil admite a presença de mais de um sócio ostensivo (parágrafo único do art. 996), o que poderá gerar confusão com a sociedade em comum. Isso poderá suceder, também, quando o sócio participante se imiscuir na gestão social (parágrafo único do art. 993), tornando difícil, na prática, a distinção entre as duas figuras (sociedade em comum e SCP). FRANÇA, Erasmo Valladão Azevedo e Novaes. Op. cit., p. 121.
} 
SALGADO $^{190}$ menciona uma hipótese possível, mas curiosa, em que um mesmo sócio ora comparece como sócio ostensivo e ora como sócio participante. É o caso, por exemplo, de sociedade entre A e B para compra e venda de um determinado produto de comércio durante o prazo de 5 (cinco) anos. Pelo contrato, A se incumbirá das compras e B das vendas. A vai aos centros de produção, efetua as aquisições em seu nome individual, é o único devedor do preço e também o único credor das quantidades convencionadas. Já B, que se encarregou das revendas, recebe os produtos, ajusta as condições do negócio, entrega a mercadoria e recebe o preço. A e B prestam contas entre si, verificam os lucros e as perdas e os dividem na proporção convencionada.

Ademais, convém analisar a possibilidade de pessoas físicas e/ou jurídicas residentes no exterior participarem como sócias de sociedades em conta de participação.

Inicialmente analisaremos a possibilidade das pessoas físicas e/ou jurídicas residentes no exterior participarem como sócias participantes do referido tipo societário. Em seguida, passaremos a tratar da eventual viabilidade de pessoas físicas e/ou jurídicas residentes no exterior participarem como sócias ostensivas de sociedades em conta de participação.

Entendemos que é possível a participação de pessoas físicas e/ou jurídicas residentes no exterior como sócias participantes de sociedades em conta de participação. No entanto, nestes casos, deve-se observar o disposto na Lei n. ${ }^{\circ} 4.131$, de 03 de setembro de 1962 .

A referida lei define o conceito de capital estrangeiro e cria um serviço especial de registro, aplicável a investimentos estrangeiros diretos. Portanto, a participação de sócio não residente em sociedades em conta de participação, como sócio participante, está sujeita ao registro no Sistema do Banco Central do Brasil - Sisbacen.

O registro no Sisbacen de aportes para participação em sociedades em geral é realizado no módulo de investimento estrangeiro direto. No entanto, tendo em vista que as sociedades em conta de participação não possuem personalidade jurídica e que o sócio ostensivo possui atuação perante terceiros, o aporte de recursos deverá ser realizado no patrimônio especial, alocado na esfera patrimonial do sócio ostensivo.

${ }^{190}$ SALGADO, Paulo Cavalcanti. Op. cit., p. 67-68. 
Portanto, o sócio participante estrangeiro deverá entregar os recursos ao sócio ostensivo brasileiro, na modalidade de transmissão de propriedade ou posse, para sua utilização nas atividades sociais pretendidas.

Ocorre que, pelo fato da sociedade em conta de participação não possuir personalidade jurídica, o Banco Central do Brasil não permite que o registro da referida operação seja realizado na modalidade "investimento direto". ${ }^{191}$

De acordo com a atual configuração do Sistema do Banco Central do Brasil - Sisbacen -, se o aporte for realizado na modalidade "investimento estrangeiro direto", será entendido como um aporte no capital social do sócio ostensivo brasileiro e não como um aporte no patrimônio especial da sociedade em conta de participação. ${ }^{192}$

Portanto, na prática, há uma impossibilidade de se formalizar os aportes de sócio participante residente no exterior. Além da inviabilidade do Sistema do Banco Central do Brasil, também não há rubrica apropriada para fechamento de câmbio referente a aportes em sociedades em conta de participação.

Com isso, nos moldes atuais, há uma inviabilidade prática de se implementar a situação ora analisada, o que faz como que, em determinados casos, os aportes dos sócios participantes sejam registrados no Banco Central do Brasil em uma modalidade de registro que permita a transmissão da posse e/ou da propriedade. No entanto, os referidos registros não correspondem de forma fiel à realidade.

Na prática, uma opção para contornar esta questão seria a constituição, pela pessoa residente no exterior, de uma sociedade limitada no Brasil para que a pessoa jurídica participe como sócia participante da sociedade em conta de participação.

\footnotetext{
${ }^{191}$ A Lei n. ${ }^{\circ} 11.371 / 2006$, em seu artigo $5^{\circ}$, prevê que: "Fica sujeito a registro em moeda corrente nacional, no Banco Central do Brasil, o capital estrangeiro investido em pessoas jurídicas no País, ainda não registrado e não sujeito a outra forma de registro no Banco Central do Brasil" (destaques nossos).

192 Informações obtidas a partir de consulta ao Banco Central do Brasil mediante envio de correspondência eletrônica ao referido órgão público.
} 
Entendemos que a elaboração de estruturas mais complexas e custosas para contornar a lacuna do Sistema do Banco Central do Brasil não faz sentido e até mesmo contraria os princípios das sociedades em conta de participação, que prezam por uma sociedade menos burocrática.

Assim, entendemos que a solução mais lógica para a problemática exposta acima envolveria a revisão, por parte do Banco Central do Brasil, de seu sistema, e a criação de rubricas de registro que permitissem o registro de investimentos aportados por sócios participantes estrangeiros em sociedades em conta de participação brasileiras.

Ademais, este item também abordará a possibilidade de pessoa física e/ou jurídica residente no exterior participar como sócia ostensiva de sociedades em conta de participação.

Neste caso, o sócio participante residente no Brasil remeteria recursos, bens e/ou serviços para o exterior. Entendemos ser possível esta alternativa. Nesta hipótese, o sócio participante brasileiro deverá se atentar para as hipóteses em que há obrigatoriedade de se realizar a Declaração de Capitais Brasileiros no Exterior (DCBE) perante o Banco Central do Brasil.

Nesta hipótese, convém discutir a respeito da possibilidade de tal relação jurídica constituir sociedade em conta de participação.

Isto porque a relação jurídica poderá ser regulada por direito estrangeiro, no qual a figura da sociedade em conta de participação pode não existir.

Ademais, é importante ponderar a respeito da obrigatoriedade do sócio ostensivo estrangeiro, que atuará perante terceiros no Brasil, constituir procurador no Brasil ao menos para receber citação judicial.

Entendemos que a obrigatoriedade de constituição de procurador por sócio ostensivo estrangeiro constitui requisito mínimo que deveria ser exigido para resguardar os interesses do País. 
O tema de participação de sócio estrangeiro - ostensivo ou participante em sociedade em conta de participação merece, a nosso ver, mais atenção do legislador, quer seja para atualizar o Sistema do Banco Central do Brasil - Sisbacen - de forma a refletir a disciplina das sociedades em conta de participação, quer seja para fixar regras e requisitos mínimos para a participação dos sócios ostensivos estrangeiros em sociedades em conta de participação.

Por fim, convém analisar também a possibilidade de existência de sociedades em conta de participação com participação de sócios ostensivos de diferentes nacionalidades ou então com sócios participantes de diferentes nacionalidades.

Com relação à possibilidade de sócios participantes de diferentes nacionalidades, entendemos que essa alternativa é viável e que, quando conjugada como a existência de sócios ostensivos brasileiros, deverá ser respeitada a legislação pátria aplicável. Nestes casos, também é válida a discussão exposta acima a respeito da inexistência de rubrica específica no Sistema do Banco Central do Brasil que permita o registro de investimento estrangeiro.

Outra discussão diz respeito à possibilidade de existência de sócios ostensivos de diversas nacionalidades. A discussão, neste caso, envolve a aplicação de diferentes legislações a uma mesma sociedade e até mesmo a possibilidade da legislação de um determinado país não prever a existência de sociedades em conta de participação. Além disso, caso o sócio ostensivo vier a atuar no Brasil, deveria respeitar regras como, por exemplo, a constituição de procuradores no País.

\section{V.1.2 Admissão de novos sócios}

Este item abordará a admissão de novos sócios na sociedade em conta de participação. 
A respeito da admissão de sócio, o artigo 995 do Código Civil de 2002 prevê que, "salvo estipulação em contrário, o sócio ostensivo não pode admitir novo sócio sem o consentimento expresso dos demais".

Portanto, o Código Civil de 2002 veio a determinar, a nosso ver de forma acertada, a disciplina de admissão de sócios em sociedades em conta de participação.

Sob a égide do Código Comercial e do Código Civil de 1916 haviam discussões a este respeito. ${ }^{193}$

Ainda a este respeito, é importante mencionar que o Código Civil de 2002, ao revogar as disposições do Código Civil de 1916, não reproduziu o disposto no artigo 1.388, que também estavam previstas no artigo 334 do Código Comercial e que previam a possibilidade de associação de um estranho ao quinhão social de um dos sócios, independentemente de autorização dos demais sócios. A referida disciplina era denominada de participação subordinada ou subparticipação. ${ }^{194}$

\footnotetext{
${ }^{193}$ A respeito deste tema, durante a vigência do Código Comercial, Mauro Brandão Lopes esclareceu que: "A atual legislação italiana sobre a conta de participação estabelece que, salvo convenção em contrário, o sócio ostensivo não pode dar participação no mesmo estabelecimento ou nos mesmos negócios a outras pessoas, sem o consentimento dos associados existentes. O dispositivo, com a complementação de outros, mostra ao meu ver a natureza do instituto no direito italiano, que como já notei parece supor a preexistência de um estabelecimento cujo titular atribui a outrem uma participação nos seus lucros e perdas. A concepção do instituto, segundo a qual êle consiste em simples meio de o comerciante conseguir capital sem revelar o nome de seu financiados, leva naturalmente à ideia de que, do mesmo modo que conseguiu o primeiro, dando-lhe determinada participação, poderá legitimamente conseguir outro, dando-lhe também uma participação, e assim indefinidamente, até esgotar-se a sua quota. De acordo com tal concepção, era preciso um dispositivo que proibisse tal parcelamento ou esfacelamento da parte do sócio ostensivo, mediante admissão de novos sócios, à revelia dos sócios participantes. E a própria concepção demonstra que, no direito italiano também, a sociedade em conta de participação é verdadeira sociedade.

Tal proibição, no direito brasileiro, seria realmente desnecessária, porque ela decorre da própria natureza social da conta de participação e da sistemática do Código Comercial. Como verdadeira sociedade, ela se constitui por contrato do qual um dos elementos essenciais é o consenso das partes, decorrendo daí, no nosso direito, que nenhum novo sócio pode ser admitido, nas sociedades de pessoas reguladas pelo Código Comercial, sem consentimento de todos.” (LOPES, Mauro Brandão. Op. cit., p. 100-101).

Em sentido contrário, vide Pontes de Miranda: "O sócio participante ativo, ou os sócios participantes ativos, que admitem outro sócio participante inativo, ou outros sócios participantes inativos, não precisam, na opinião de alguns, do assentimento do sócio participante inativo, ou dos sócios participantes inativos." (PONTES DE MIRANDA, Francisco Cavalcanti. Op. cit., p. 335).

${ }^{194} \mathrm{~A}$ esse respeito, Mauro Brandão Lopes já era contrário à aplicação do artigo 334 do Código comercial às sociedades em conta de participação. (LOPES, Mauro Brandão. Ensaio sôbre a conta de participação... cit.,, p. 101).
} 


\section{V.1.3 Saída de sócios}

Este item abordará as hipóteses de saída de sócios em decorrência de alienação de participação societária, exclusão de sócios, dissolução parcial, falecimento, falência do sócio ostensivo e falência do sócio participante.

Convém ressaltar, inicialmente, determinadas características aplicáveis a todas as hipóteses de saída de sócios.

Nos casos de saída de sócios - por qualquer uma das causas que serão expostas abaixo - os haveres devem ser calculados de acordo com a regra constante no instrumento de constituição da sociedade em conta de participação ou em documento societário posterior que alterou a disciplina relativa à apuração de haveres.

Em caso de silêncio do contrato a este respeito, a apuração de haveres deve ser realizada de acordo com o valor patrimonial ou valor econômico da participação societária, o que for mais próximo da realidade e de acordo com balanço ou balancete patrimonial levantado especialmente para este fim.

Também merecem destaque os casos em que o único sócio ostensivo sai da sociedade em conta de participação sem que outro sócio ostensivo ingresse no mesmo ato e também nos cenários em que a saída de sócio enseja que a sociedade se caracterize como sociedade unipessoal, o que não é possível no caso das sociedades em conta de participação.

Entendemos que na hipótese prevista acima, a saída de sócio ensejará a dissolução da sociedade em conta de participação. Assim, caso o sócio que tem o seu vínculo social dissolvido seja o único da categoria (dos ostensivos ou dos participantes), tal fato acarretará a dissolução total da sociedade, tendo em vista a falta de preenchimento de uma das categorias de sócio.

Não se aplica, portanto, às sociedades em conta de participação o quanto previsto no artigo 1.033, inciso IV, do Código Civil de 2002 a respeito da possibilidade da sociedade permanecer unipessoal por tempo determinado. 
Por outro lado, e, especialmente, no que se refere ao sócio ostensivo, mesmo que existente outro, caso a contribuição daquele que sai da sociedade em conta de participação seja essencial, poderá ocorrer a dissolução total da sociedade. Neste caso, ocorrerá a dissolução da sociedade em virtude da inexequibilidade de preenchimento do seu fim, nos termos do artigo 1.034, inciso II, do Código Civil de 2002.

O mesmo pode ocorrer na hipótese de saída de sócio participante, já que a sua saída, mesmo que existentes outros sócios da mesma categoria, pode ensejar a perda de um elemento essencial à vida social, como por exemplo, poderá acarretar o término de eventual contrato de locação aportado pelo sócio participante e que se mostre indispensável para as atividades sociais.

\section{V.1.3.1 Cessão de participação societária}

Este subitem abordará a alienação de participações societárias detidas em sociedades em conta de participação.

É possível a cessão da participação de sócios ostensivos e a cessão da participação de sócios participantes. ${ }^{195}$

\footnotetext{
${ }^{195}$ As regras a serem utilizadas, com relação à cessão da participação dos sócios ocultos e dos sócios ostensivos variam consoante o regime jurídico do fundo social. Se o regime é o da transferência de propriedade, o sócio oculto retirante cede, ao novo sócio, os direitos e obrigações que possui, com relação ao sócio ostensivo, em virtude da Conta de Participação. Neste mesmo regime, o sócio ostensivo transfere ao novo sócio ostensivo a propriedade do fundo social, bem como os direitos e obrigações que adquiriu em razão de atividades ligadas à Conta de Participação. No regime de co-propriedade, a cessão implica a transmissão de quota ideal do condomínio, de propriedade do retirante. Caso o retirante seja o sóciogerente, ele passará a administração a outro sócio, escolhido para ser o novo gerente. No regime da cessão, o cedente é obrigado a manter o status quo da sua contribuição. Ou seja, o retirante perde a qualidade de sócio, mas continua a manter relações com o sócio ostensivo, a título de proprietário daquilo com que entrou para o fundo social. Um exemplo talvez ajude a clarear a situação: a contribuição do sócio Caio é o usufruto de um automóvel. O sócio Caio mantém uma dupla relação: a de sócio, face à sociedade, e a de nu-proprietário face ao usufrutuário, o sócio ostensivo. Ao deixar a sociedade, Caio deixa de ser sócio, porém, continua a ser nu-proprietário. O que ele cede é a sua posição de sócio e não a de nu-proprietário. Por sua vez, se o sócio retirante é o gerente, tal como no regime de transferência de propriedade, ele fará passar, para o patrimônio do novo sócio ostensivo, o fundo social. Por último, resta abordar a cessão no regime de manutenção de propriedade. Neste regime, a saída do sócio significa também a saída da parcela do fundo social, que se encontra no seu patrimônio. (ALMEIDA, José Gabriel de Assis de. Op. cit., p. 108-109).
} 
A este respeito, deverá ser aplicada a previsão contida no artigo 995 do Código Civil de 2002, que prevê que, salvo estipulação em contrário, o sócio ostensivo não pode admitir novo sócio sem o consentimento dos demais. ${ }^{196}$

A respeito da alienação de participação societária e dos direitos daí decorrentes, convém ressaltar que é importante ter em mente que as sociedades em conta de participação constituídas para o fim de angariar fundos e participar de outra sociedade - limitada ou por ações - pode fazer com que a posição do sócio participante não fique bem resguardada.

Isto porque o sócio participante aportará recursos para que o sócio ostensivo adquira quotas/ações de sociedade operacional (limitada ou por ações). Ocorre que os direitos políticos e patrimoniais inerentes à sociedade operacional serão exercidos pelo sócio ostensivo e as cláusulas do contrato de constituição da sociedade em conta de participação não podem ser opostas perante terceiros.

Por esta razão, cláusulas previstas no instrumento de constituição da sociedade em conta de participação no sentido de que os sócios participantes terão, por exemplo, direito de preferência para aquisição das quotas/ações da sociedade operacional são de difícil - senão de impossível - execução. ${ }^{197}$

\footnotetext{
${ }^{196}$ A este respeito, Carlos Guimarães de Almeida entende que: "Como sociedade que é, tendo como um dos seus característicos típicos a affectio societatis, é evidente que nenhum dos seus sócios pode ceder a sua parte sem o consentimento dos demais. Ripert é categórico nesse sentido, dizendo: "La part de chaque associe dans la societé em participation est par suíte une part d'interêt. Ele n'est pas cessible sans le consentment des autres associes." (ALMEIDA, Carlos Guimarães de. A virtuosidade da sociedade em conta de participação. Revista de Direito Mercantil, Industrial, Econômico e Financeiro, n..$^{\circ}$ 08, 1972, p. 58).

${ }^{197}$ A este respeito, vide TJSP. Agravo de Instrumento n. ${ }^{\circ}$ 565.775.4/1-00, rel. João Carlos Garcia, j. 02.12.2008. TJSP. Agravo de Instrumento n. ${ }^{\circ}$ 994.09.284526-3, rel. João Carlos Garcia, j. 02.02.2010. Nas referidas decisões judiciais, há discussão a respeito de caso que envolve a SPPatrim Administração e Participações Ltda. (e sua sucessora Cabral Real Estate do Brasil Investimentos Ltda.) e Bueno Netto Empreendimentos Imobiliários Ltda.. A SPPatrim constituiu sociedade em conta de participação com a Bueno Netto para que esta última pudesse angariar fundos para adquirir participação societária na Golf Village Empreendimentos Imobiliários S.A., cujo objeto envolvia o desenvolvimento de empreendimento imobiliário na Marginal Pinheiros. Após desavenças entre os sócios da SCP, a Tecnisa S.A. ingressou no capital social da Golf Village Empreendimentos Imobiliários S.A. mediante subscrição de ações e diluiu a participação da Bueno Netto na referida sociedade e, por consequência, diluiu a participação da sociedade em conta de participação na referida sociedade. A SPPatrim argumentou que o instrumento de constituição da sociedade em conta de participação previa o direito de preferência, que não the foi garantido. No entanto, o pleito da SPPatrim não foi acatado. É importante destacar que grande parte das
} 
Assim, o sócio ostensivo poderá alienar a participação da sociedade em conta de participação na sociedade operacional e, com isto, esvaziar o objeto da sociedade em conta de participação. Contra isto, o sócio participante apenas terá direito de pleitear perdas e danos e outras medidas contra o sócio ostensivo.

A este respeito, vide SALGADO: ${ }^{198}$

\begin{abstract}
Nenhuma destas faculdades pode ser negada ao sócio ostensivo, ainda mesmo quando o contracto social lhe tenha cerceado a órbita da acção. Qualquer restricção ao seu amplo poder de alienar e gravar os bens sociaes não tem efeito relativamente a terceiros em virtude da índole oculta da sociedade e de operar o sócio ostensivo em seu próprio nome. Os sócios não podem oppor aos terceiros um contracto social que não foi publicado e que o não poderia ser, sem que a sociedade em conta de participação perdesse o seu caráter diferencial. O excesso de poderes da parte do sócio ostensivo dá aos sócios secretos direitos a reparação, nunca à anulação do acto, relativamente aos terceiros, salvo o caso do art. 327 do Código Commercial.
\end{abstract}

\title{
V.1.3.2 Exclusão de sócio
}

Este subitem pretende avaliar as hipóteses de exclusão de sócios.

O procedimento para exclusão de sócio em sociedade em conta de participação pode envolver procedimentos judiciais, estando a possibilidade de exclusão de sócios prevista ou não no instrumento de constituição da sociedade em conta de participação. ${ }^{199}$

discussões que envolvem o caso foi decidida por arbitragem, razão pela qual não tivemos acesso a todas as discussões a respeito do tema.

Ainda a respeito deste caso, vide Processo Administrativo SP n. ${ }^{\circ}$ 2008-108, da Comissão de Valores Mobiliários, rel. Alexsandro Broedel Lopes, j. 19.10.2011.

${ }^{198}$ SALGADO, Paulo Cavalcanti. Op. cit., p. 143.

${ }^{199}$ A respeito da exclusão de sócios sob a égide do Código Comercial, vide Paulo Cavalcanti Salgado "O nosso Código admite a exclusão, embora não a tenha regulamentado. O art. 339 allude a sócio que se despedir ou for despedido com causa justificada. Portanto, a validade da cláusula de exclusão não pode ser impugnada como humilhante. Aos sócios compete estabelecer as condições de sua existência, fixando o número de associados necessários para determinar a exclusão, as causas que a motivam, etc". (Idem, p. 147). 
Além disto, a exclusão de sócio somente pode ser requerida judicialmente caso os sócios titulares da maioria dos fundos sociais assim deliberem e haja pleito em juízo fundamentado em justa causa. ${ }^{200}$

Dentre as hipóteses de justa causa para exclusão de sócio, destacam-se a existência de sócio remisso, conforme previsto no artigo 1.004 do Código Civil de 2002, a ocorrência de falta grave no cumprimento de suas obrigações ou incapacidade superveniente, conforme previsto no artigo 1.030, caput, do Código Civil de 2002, bem como a quebra de affectio societatis e a prática de ato de inegável gravidade, conforme previsto no artigo 1.085 do Código Civil de 2002. ${ }^{201}$

Na hipótese de sócio remisso, o cronograma de integralização deve seguir o previsto no contrato. Em caso de silêncio do contrato, o aporte é devido desde a data de assinatura do instrumento de constituição da sociedade em conta de participação ou da alteração do contrato social que previu o aporte. Há autores que defendem, ainda, que o aporte pode ser cobrado após o decurso de 30 (trinta) dias a contar do envio de notificação ao sócio a este respeito. ${ }^{202}$

Além disto, há discussão a respeito de que tem legitimidade para cobrar a integralização do sócio remisso.

Tendo em vista que a sociedade em conta de participação não tem personalidade jurídica e capacidade para estar em juízo, a sociedade não pode cobrar o aporte de capital do sócio remisso.

\footnotetext{
${ }^{200}$ De acordo com Pontes de Miranda: “A sociedade em conta de participação, que é intuitu personae, não pode ser privada de sócio, mesmo com a deliberação de todos os outros, se não há justa causa. As justas causas podem ser exemplificadas no contrato e a cláusula que as restrinja não afasta as que se impõem por natureza, como por exemplo, a inimizade pessoal que sobreveio. (PONTES DE MIRANDA, Francisco Cavalcanti. Op. cit., p. 343).

${ }^{201}$ A este respeito, Mauro Brandão Lopes preceitua: "O descumprimento do contrato social por parte de qualquer dos sócios possibilita que o outro pleiteie a dissolução parcial da sociedade”. Mauro Brandão Lopes também prevê como hipóteses de descumprimento contratual: "Não realização da quota, negligência manifesta na administração dos negócios sociais e na sua fiscalização, oposição ao exercício normal do direito de fiscalização, reconhecido pela lei a todos os associados, recusa sistemática a concorrer às deliberações sociais, incapacidade técnica notória do sócio que resulta na impossibilidade de realizar a sua quota de indústria, apropriação indébita de soma do ativo, retirada para sua conta de somas superiores às convencionadas, mudança antiestatutária da sede, ausência”. (LOPES, Mauro Brandão. Ensaio sôbre a conta de participação... cit., p.111)

${ }^{202}$ RAMIRES, Rogério. Op. cit., p. 125.
} 
Há quem defenda que a integralização de capital pode ser cobrada apenas pelo sócio ostensivo. Há autores que defendem que o aporte pode ser cobrado por todos os sócios. ${ }^{203} \mathrm{E}$, ainda, há autores que defendem que os credores do sócio ostensivo podem cobrar a integralização.

Entendemos que o direito de cobrar a integralização do sócio remisso deve ser estendido a todos os sócios, já que todos têm interesse na atividade social. Ademais, nas relações entre os sócios, é sabido que todos podem opor a sociedade em conta de participação e pleitear a resolução do conflito, inclusive via propositura de ação judicial. $^{204}$ Além disto, restringir a cobrança ao sócio ostensivo pode ensejar consequências indesejadas, já que o sócio ostensivo também poderá ser o sócio remisso de quem deve ser cobrada a contribuição.

\section{V.1.3.3 Falecimento de sócio}

As disposições do artigo 1.028 do Código Civil de 2002, que disciplina as consequências do falecimento de sócios de sociedades simples, devem ser aplicadas às sociedades em conta de participação.

Em caso de falecimento de sócio, poderá ocorrer a liquidação da participação societária, com apuração dos haveres correspondentes. Também poderá ocorrer a dissolução da sociedade, se assim deliberarem os demais sócios. Por fim, outra alternativa possível é a substituição do sócio falecido por meio do ingresso dos herdeiros no quadro social.

O instrumento de constituição da sociedade em conta de participação poderá regular previamente as consequências do falecimento de sócio de forma que, nos casos de falecimento, a solução já estará pré-acordada.

Assim, o instrumento de constituição da sociedade em conta de participação poderá conter disposições que disciplinem, por exemplo, que a participação societária

\footnotetext{
${ }^{203}$ Conforme GRANDI, Salvatore Giovanni. L'associazione in partecipazione. Casa Editrice Dottor Francesco Vallardi. Milano. 1939. p. 68.

${ }^{204}$ A este respeito, vide item III.4.2 desta dissertação.
} 
será sempre liquidada e que os herdeiros nunca ingressarão na sociedade. Esta medida poderá servir para proteger a sociedade do ingresso de terceiros alheios à affectio societatis e ao objeto social. No entanto, o pagamento dos haveres correspondentes à participação do falecido poderá inviabilizar a continuidade da sociedade, que terá que desembolsar caixa equivalente ao valor patrimonial ou ao valor econômico da participação societária do sócio falecido.

Por outro lado, o instrumento de constituição da sociedade poderá prever que os herdeiros sempre ingressarão na sociedade em substituição do sócio falecido. Conforme exposto acima, essa medida pode ensejar o ingresso de terceiros alheios ao objeto social e à affectio societatis.

Uma outra alternativa possível seria prever no instrumento de constituição da sociedade que os herdeiros poderão ingressar na sociedade, salvo deliberação em sentido contrário tomada por sócios titulares da maioria dos fundos sociais, excluída a participação do sócio falecido. Esta medida poderá permitir que a maioria delibere a respeito dos rumos da sociedade à luz da situação financeira da sociedade à época da sucessão e das características pessoais e profissionais dos herdeiros.

\section{V.1.3.4 Direito de retirada}

Entendemos que a disciplina do artigo 1.029 do Código Civil de 2002, que regula o direito de retirada nos casos de sociedades simples, é aplicável às sociedades em conta de participação.

O referido dispositivo legal prevê que além dos casos previstos na lei ou no contrato, qualquer sócio pode retirar-se da sociedade; se de prazo indeterminado, mediante notificação aos demais sócios, com antecedência mínima de sessenta dias; se de prazo determinado, provando judicialmente a justa causa. ${ }^{205}{ }^{206}$

\footnotetext{
${ }^{205}$ Disponível em: <www.planalto.gov.br>. Acesso em: 20 out. 2013.

${ }^{206}$ Disponível em: <www.planalto.gov.br>. Acesso em: 20 out. 2013.
} 
O parágrafo único do referido artigo prevê ainda que nos trinta dias subsequentes à notificação, podem os demais sócios optar pela dissolução da sociedade. $^{207}$

Assim, se a sociedade em conta de participação for constituída por prazo indeterminado, qualquer dos sócios poderá exercer o direito de retirada mediante envio de notificação com 60 (sessenta) dias de antecedência. Já se a sociedade em conta de participação for constituída por prazo determinado, o direito de retirada somente poderá ser exercido judicialmente mediante prova da justa causa.

Ocorre que, conforme será exposto no Capítulo VI, abaixo, a saída de um dos sócios poderá acarretar a dissolução da sociedade, seja porque a saída ensejou a ausência de pluralidade de sócios, seja porque a saída acarretou a inexistência de sócio ostensivo ou ainda porque o sócio que exerceu o direito de retirada era essencial para o prosseguimento das atividades sociais.

\section{V.1.3.5 Falência de sócio ostensivo e falência de sócio participante}

A sociedade em conta de participação não pode falir ou tornar-se insolvente. O que pode ocorrer é a falência de seus sócios.

O artigo 994, $\S \S 2^{\circ}$ e $3^{\circ}$, do Código Civil de 2002 disciplina este tema.

A respeito da falência do sócio ostensivo, o referido dispositivo legal prevê que o referido fenômeno acarreta a dissolução da sociedade e a liquidação da respectiva conta, cujo saldo constituirá crédito quirografário.

O sócio ostensivo pode falir por obrigações oriundas de operações estranhas à sociedade em conta de participação ou por motivos relacionados ao objetivo social. Ocorre que o sócio ostensivo obriga os fundos sociais até por obrigações pessoais.

\footnotetext{
${ }^{207}$ Disponível em: <www.planalto.gov.br>. Acesso em: 20 out. 2013.
} 
A este respeito, SALGADO:

Si o sócio gerente cahe em fallencia por negocio particular, o sócio secreto é credor de toda sua quota e si verifica pela prestação de contas a que está obrigado o syndico para com o sócio secreto que os negócios da sociedade em conta de participação deram lucros, o sócio secreto tem direito a fazer valer, na falência, o crédito d'estes lucros, além do de sua quota. ${ }^{208}$

Fato é que, em caso de falência do sócio ostensivo, não haverá distinção entre credores individuais e sociais e a inexistência de privilégio dos últimos sobre os primeiros relativamente ao patrimônio da sociedade.

Assim, os credores particulares do sócio ostensivo tem o direito de pleitear os bens do sócio ostensivo, inclusive aqueles aportados ou que, de direito, deveriam ser atribuídos ao sócio participante. Por esta razão, o sócio participante também deverá habilitar o seu crédito no processo de falência e, por consequência, também tornar-se-á credor do sócio ostensivo.

Já com relação à falência do sócio participante, o texto da lei prevê que o contrato social fica sujeito às normas que regulam os efeitos da falência nos contratos bilaterais do falido. Em outras palavras, o administrador judicial poderá optar por manter a participação do sócio participante na sociedade em conta de participação e utilizar os resultados que vierem a ser apurados para a quitação das dívidas habilitadas no processo de falência ou então optar por resolver o contrato com relação ao referido sócio participante e receber os correspondentes haveres.

Como já abordado anteriormente, é possível que o objeto da sociedade em conta de participação seja empresário ou não empresário. Entendemos que a disciplina do artigo 994, $\S \S 2^{\circ}$ e $3^{\circ}$, do Código Civil de 2002 também deve ser aplicável no caso dos sócios que não sejam empresários ou sociedades empresárias e, portanto, que estejam sujeitos a insolvência civil.

A natureza da contribuição do sócio participante é importante no caso de sobrevir a falência do sócio ostensivo.

${ }^{208}$ SALGADO, Paulo Cavalcanti. Op. cit., p. 137. 
Se a contribuição do sócio participante é realizada a título de transferência de propriedade e/ou aporte de recursos em moeda corrente nacional, o bem participa da norma geral dos bens sujeitos aos efeitos da falência e o crédito do sócio participante constitui crédito quirografário, nos termos do artigo 994, $\S 2^{\circ}$, do Código Civil de $2002 .^{209}$

No entanto, se o sócio participante mantiver a propriedade do bem e apenas transferiu ao sócio ostensivo o seu uso ou gozo, ou sobre este estabeleceu uma comunhão, então o sócio participante pode reivindicar o bem ou, no caso da comunhão, a parte que lhe pertencer.

\footnotetext{
${ }^{209}$ A este respeito, convém mencionar decisão judicial em recurso de agravo de instrumento interposto por Carlos Alberto Schoups contra decisão que negou provimento ao recurso apresentado e que manteve decisão no sentido de arrecadar todas as máquinas que integram no patrimônio de sociedade falida - ESB Eletronic Service Indústria e Comércio Ltda. (Agravada). O Agravante alega que 50\% das máquinas são de sua propriedade, já que constituiu sociedade em conta de participação na qual o agravante participava como sócio oculto e a Agravada participava como sócia ostensiva. Aduz ainda que no ato de constituição a Agravada aportou ao patrimônio da SCP determinadas máquina, enquanto que o Agravante aportou recursos em moeda corrente nacional e que no decorrer dos anos a SCP passou a ter, dentre seus ativos, 132 máquinas. Em virtude desse fato, o Agravante alega ser proprietário da metade das 132 máquinas, já que sua participação na SCP era de $50 \%$ do patrimônio especial. Destaca que cabia ao Agravante o gerenciamento dos negócios da SCP e que recebia pró-labore em contrapartida a tais serviços. Afirma que a Agravada cedeu sua participação na sociedade para a Flag International e, na sequência, foi decretada a falência da Agravada e foi rescindido de pleno direito o contrato firmado entre Agravante e Agravado. A decisão judicial foi no sentido de afirmar que as 132 máquinas integram o patrimônio da sociedade falida - Agravada - e que, portanto, devem ser arrecadadas em prol da massa falida. A decisão ainda menciona que o Agravante mencionou gerenciar as atividades da SCP e que essa afirmação enseja sua responsabilidade solidária pelas obrigações contraídas pela SCP. A decisão menciona ainda que a decretação da falência do sócio ostensivo enseja a dissolução da SCP e consequente procedimento de prestação de contas, razão pela qual o Agravante, se intenta ser merecedor de recebimento de máquinas ou recursos, deve ser considerado credor quirografário, nos termos do art. $994, \S 2^{\circ}$ e 996 do Código Civil de 2002 (TJSP, Agravo de Instrumento n. ${ }^{\circ}$ 990.10.287623-3, rel. Des. Manoel de Queiroz Pereira Calças, j. 19.10.2010).

O Código Civil de 2002 contém previsão específica a respeito da natureza do crédito de sócios de sociedade em conta de participação no sentido de que os referidos créditos constituem créditos quirografários. Já a Lei n. ${ }^{\circ} 11.101$, de 09 de fevereiro de 2005, em seu artigo 83, inciso VIII, prevê que os créditos de sócios são classificados como subordinados. O artigo 994, § $2^{\circ}$ do Código Civil de 2002 não foi alterado a partir da vigência da Lei n. $.^{\circ} 11.101 / 05$ e, portanto, entendemos que a classificação específica do Código Civil de 2002 deve prevalecer ao disposto na Lei n. ${ }^{\circ}$ 11.101/05.
} 


\section{V.2 Responsabilidade dos sócios da sociedade em conta de participação}

Este item tratará da responsabilidade dos sócios das sociedades em conta de participação. $^{210}$

Para tanto, dividiremos este item em 2 (dois) subitens. O primeiro subitem analisará a responsabilidade dos sócios das sociedades em conta de participação perante terceiros. Já o segundo subitem analisará as regras de responsabilidade dos sócios das sociedades em conta de participação na relação interna da sociedade.

\section{V.2.1 Responsabilidade perante terceiros}

O artigo 991 do Código Civil de 2002 prevê que o sócio ostensivo exerce a atividade constitutiva do objeto social sob sua exclusiva responsabilidade.

Esta análise guarda estreita relação com a disciplina do patrimônio especial da sociedade em conta de participação.

Conforme previsto no Capítulo IV, acima, a responsabilidade do sócio ostensivo é tal que os credores das sociedades em conta de participação não têm reservado para si o patrimônio especial para execução em caso de inadimplemento. Da mesma forma, os credores particulares do sócio ostensivo e os credores sociais podem perseguir todo o patrimônio do sócio ostensivo, inclusive o patrimônio especial, para satisfação de seu crédito.

\footnotetext{
${ }^{210}$ Antes de adentrar no tema de responsabilidade dos sócios de sociedades em conta de participação, convém destacar interessante excerto de autoria da Professora Rachel Sztajn sobre a responsabilidade dos sócios de sociedades comerciais. In verbis: "A responsabilidade solidária e ilimitada dos sócios - todos ou alguns - das sociedades comerciais tem fundamento no binômio risco-responsabilidade. Dada a importância do crédito para a atividade comercial, uma das formas que a coletividade de mercadores encontrou para facilitar a extensão aos seus membros, mesmo impondo sacrifícios a todos individualmente, foi essa. A fim de preservar a credibilidade da classe e propiciar condições para o desenvolvimento da atividade, estabeleceu-se, como regra, a solidariedade. Essa função da solidariedade explica porque se admite limitar a responsabilidade do sócio que não participa direta e ativamente da administração da sociedade e serve para que se estabeleça um esquema de administração que mantenha a característica. O risco de perder todos os bens no exercício de uma atividade deve servir de freio ao poder que nasce com o exercício de uma atividade e, consequentemente, atuar como instrumento de proteção de toda classe de mercadores." (SZTAJN, Rachel. Contrato de sociedade... cit., p. 26).
} 
O sócio ostensivo responderá, portanto, perante terceiros por atos que exerceu e poderá, inclusive, ter seu patrimônio pessoal comprometido por dívidas da sociedade em conta de participação. ${ }^{211} \mathrm{O}$ sócio ostensivo, posteriormente, terá ação regressiva contra os sócios participantes. Em nenhuma hipótese o sócio ostensivo poderá opor a existência da sociedade em conta de participação a terceiros. ${ }^{212}$

No caso das sociedades em conta de participação, portanto, os bens particulares dos sócios podem ser atingidos por dívidas da sociedade. Isto porque, o sócio ostensivo responde em nome próprio pelos atos sociais e não há especialização patrimonial perante terceiros. No caso dos sócios participantes, os seus bens pessoais podem ser atingidos na hipótese de tomar parte dos negócios sociais perante terceiros.

A afetação patrimonial, portanto, não produz efeitos perante terceiros e não serve, no caso das sociedades em conta de participação, para delimitar a responsabilidade dos sócios perante terceiros, em especial do sócio ostensivo. ${ }^{213}$

Conforme já mencionado no Capítulo IV, a especialização patrimonial entre os sócios de sociedades em conta de participação tem a finalidade de delimitar a responsabilidade do sócio ostensivo no que se refere à consecução do objeto social e de responsabilizá-lo em caso de desvio de bens e/ou recursos para a realização de outra atividade e/ou finalidade não relacionada com o objeto social. Portanto, a afetação patrimonial tem a finalidade de delimitar as relações internas entre os sócios no âmbito da sociedade.

A este respeito, vide o item V.2.2.

\footnotetext{
211 Tôdas as vezes que, na conta de participação, existe mais de um sócio ostensivo, a sua responsabilidade ilimitada é tão-somente pelas obrigações resultantes de operações que êle próprio realizou; nas demais, em que é simples sócio "oculto", a sua responsabilidade pode ser limitada, sem qualquer obstáculo legal.

(LOPES, Mauro Brandão. Ensaio sôbre a conta de participação... cit., p. 143).

${ }^{212}$ Disciplina distinta da regulada pelo já revogado Código Comercial, conforme detalhado no Capítulo IV.

${ }^{213}$ De forma diferente ocorre, por exemplo, na afetação patrimonial típica das sociedades incorporadoras. Neste caso, o patrimônio de afetação destinado a um determinado empreendimento imobiliário não pode ser atingido por dívidas de outro empreendimento imobiliário. Esta medida visa a proteger a economia popular.
} 


\section{V.2.2 Regras de responsabilidade dos sócios aplicáveis nas relações internas da sociedade em conta de participação}

Conforme exposto acima, o titular do patrimônio especial - no caso, o sócio ostensivo - deve sempre agir no sentido de executar as finalidades para as quais o patrimônio especial foi criado.

Nesta hipótese, portanto, o titular do patrimônio não possui discricionariedade para administrar e dispor do patrimônio especial como bem entender.

Em caso de desvio de finalidade quanto à utilização dos fundos sociais, o sócio ostensivo pode ser responsabilizado. A responsabilização do sócio ostensivo deve ser equiparada às aplicáveis a administradores de sociedades que agem em desacordo com os deveres de diligência, de lealdade, de informação, de obediência e com desvio de poder, nos termos dos artigos 153 e ss. da Lei das Sociedades por Ações. ${ }^{214}$

Ademais, se o sócio ostensivo omitir-se e não trabalhar para a persecução do objeto social, o sócio participante poderá reclamar a devolução de sua contribuição e pleitear a dissolução da sociedade. ${ }^{215}$

Os sócios participantes obrigam-se perante os sócios ostensivos nos termos previstos no contrato da sociedade em conta de participação. Assim, respeitadas as peculiaridades próprias deste tipo societário, os sócios estarão livres para regular, no

\footnotetext{
${ }^{214}$ Para José Gabriel Assis de Almeida, se o sócio ostensivo não respeitar o pacto social, terá cometido abuso de confiança, e deverá indenizar os prejuízos causados. Por outro lado, na Itália, em um caso semelhante, já se considerou o desrespeito ao contrato social como crime de apropriação indébita (cf. Grandi, p. 89).” (ALMEIDA, José Gabriel de Assis de. Op. cit., p. 95).

${ }^{215}$ Idem, ibidem.

Neste sentido, vide Pontes de Miranda: Os poderes do sócio gerente, salvo cláusula em contrário, são revogáveis a nuto, se não é êle o único sócio proprietário. Se o sócio só participante entende que o sócio gerente obrou mal em algum negócio, o que êle pode fazer é promover a dissolução da sociedade. Quando se dá a revogação de poderes quase sempre a sociedade em conta de participação se dissolve, porque o sócio participante inativo não pode recebê-los. Se a sociedade em conta de participação se compõe de sócios que escolheram dentre si o sócio gerente e foi por isso que êle figurou como se outros não pudessem ser escolhidos, nada obsta a que êle passe a ser participante inativo e alguém, que fora sócio só participante, o substitua. Aí, originalmente, há co-participação, com a igualdade inicial e a escolha do que há de figurar perante terceiros (PONTES DE MIRANDA, Francisco Cavalcanti. Op. cit., p. 346).
} 
contrato de sociedade em conta de participação, as regras aplicáveis às suas relações internas. $^{216}$

Para BRANDÃO LOPES, ${ }^{217}$ a responsabilidade do sócio participante, que pode sofrer alterações contratuais, não pode ser limitada a ponto de resguardar o valor de sua própria entrada.

Portanto, no que diz respeito às regras de responsabilidade dos sócios nas relações internas da sociedade, há uma gama de possibilidades que podem ser utilizadas. No entanto, as partes devem respeitar duas diretrizes básicas: a impossibilidade de limitar perante terceiros a responsabilidade do sócio ostensivo e a impossibilidade de limitar a responsabilidade do sócio participante de forma a resguardar o valor por ele aportado no fundo social.

Portanto, é possível que, desde que respeitadas as diretrizes básicas expostas acima, as partes fixem diferentes regras de responsabilidade dos sócios. Assim, as partes podem prever que o sócio ostensivo responderá de forma ilimitada perante terceiros e que o sócio participante responderá perante o sócio ostensivo até o limite dos valores aportados ao fundo social.

Ademais, as partes poderão prever que o sócio participante responderá perante o sócio ostensivo de forma ilimitada e solidária.

Ainda, segundo BRANDÃO LOPES, na conta de participação é também possível a estipulação de que um ou alguns sócios contribuam para a sociedade somente com a sua indústria. Nesta hipótese, a conta de participação pode, por exemplo, adotar um esquema semelhante ao daquela sociedade, no qual um ou alguns dos sócios

\footnotetext{
${ }^{216}$ Assim, não poderão os sócios contratar uma conta de participação em que todos devam se obrigar conjuntamente para com terceiros, porque é da essência da sociedade que cada sócio só pessoalmente se pode obrigar, uma vez que a obrigação conjunta implica na exteriorização da sociedade e seu consequente desvirtuamento; não podendo ainda, pela mesma razão, convencionar o uso de firma e domicílio social, diante de terceiros, embora possam eleger fôro para as questões que entre eles surgirem; não poderão, afinal, pactuar a limitação da responsabilidade do sócio ostensivo, perante terceiros, pelas obrigações sociais, nas operações por êle praticadas. (LOPES, Mauro Brandão. Ensaio sôbre a conta de participação... cit., p. 142-143).

${ }^{217}$ Idem, p. 143.
} 
"ocultos" contribuem somente com o seu trabalho, cuja perda constitui o seu único risco, no caso de prejuízos, e os demais contribuem com quotas de capital. ${ }^{218}$

\section{V.3 Participação dos sócios nos resultados}

Inicialmente, pretende-se analisar a eventual possibilidade de distribuição de lucros de forma desproporcional aos aportes realizados pelos sócios.

Ademais, este item pretende abordar uma discussão que, na visão da autora desta dissertação, é de extrema importância. Trata-se da disciplina aplicável à participação dos sócios nos prejuízos.

Este item abordará a eventual possibilidade do ato constitutivo da sociedade em conta de participação ou o ato que modifique o contrato formador da sociedade em conta de participação prever que o sócio participante não participará dos prejuízos porventura auferidos pela sociedade ou, ainda, da possibilidade do contrato prever que o sócio participante participará dos prejuízos da sociedade até o limite do capital aportado.

O tema é controverso.

Ao ser instado a se manifestar sobre o tema, o Supremo Tribunal Federal STF - posicionou-se de forma distinta em duas oportunidades.

Na primeira oportunidade, em 1958, o Supremo Tribunal Federal entendeu que não é admissível sociedade sem comunhão nas perdas e sem affectio societatis. ${ }^{219}$

Posteriormente, em 1961, o Supremo Tribunal Federal entendeu que não é leonina, e não se considera nula, a sociedade cujo contrato estipula que um dos sócios não será responsável pelas perdas, embora partilhe dos lucros. ${ }^{220}$

\footnotetext{
${ }^{218}$ Idem, p. 147.

${ }^{219}$ Conforme Re n. 38.052 , julgado, pelo Supremo Tribunal Federal, em 30.01.1958, pelo relator, Ministro Nelson Hungria.
} 
No entanto, o Código Civil de 2002, cujo início da vigência, como se sabe, é posterior a 1958 e 1961, prevê, em seu artigo 1.008, ao disciplinar as sociedades simples, que é nula a estipulação contratual que exclua qualquer sócio de participar dos lucros e das perdas. ${ }^{221}$

Assim, conforme exposto no subitem V.2.2, entendemos que é nula a cláusula do contrato de sociedade em conta de participação que preveja que o sócio participante não participa das perdas e, portanto, não é responsável por eventuais prejuízos aferidos pela sociedade.

Ao menos o montante aportado pelo sócio participante deve estar sujeito a cobrir eventuais prejuízos sociais, sendo certo que o contrato de sociedade em conta de participação delimitará a responsabilidade do sócio participante com base nesta premissa. $^{222}$

${ }^{220}$ Conforme AI n. ${ }^{\circ}$ 24.818, julgado, pelo Supremo Tribunal Federal, em 13.06.1961, pelo relator, Ministro Antônio Villas Boas.

${ }^{221}$ Sob a égide do Código Civil de 1916, Carlos Guimarães de Almeida entendia que: "Quanto à participação dos sócios participantes nos prejuízos do negócio, é unânime o entendimento de que, na falta de estipulação em contrário, deve ser ela calculada na mesma proporção da que tiver nos respectivos lucros, como opinam L. Lordi, Escarra, Lyon Caen et Renault e Houpin et Bosvieux. No direito brasileiro a contribuição do sócio participante nos prejuízos é afirmada por vários julgados, sob a consideração de que a não ser assim, faltaria à sociedade a affectio societatis, que é um dos seus indispensáveis característicos. E se a participação nos prejuízos não tiver sido determinada no contrato, será calculada na proporção do quinhão do sócio participante, ex vi do disposto no art. 302 do Código Comercial indubitavelmente aplicável à hipótese. Todavia, é válida, pois não é leonina, a cláusula que limita a responsabilidade do sócio participante nos prejuízos até o montante de seu apport, o que aproxima a sociedade em conta de participação da sociedade em comandita por ações. Na verdade, ela é uma comandita oculta." (ALMEIDA, Carlos Guimarães de. Op. cit., p. 58).

${ }^{222}$ Neste sentido, vide também Pontes de Miranda: "pois os sócios participantes sofrem as perdas se outorgarem poderes de gestão ao sócio gerente. (...) À diferença do que ocorre na sociedade de capital e indústria, na sociedade em conta de participação o sócio participante inativo tem a sua quota nos lucros e nas perdas. Quanto à participação nos lucros e nas perdas, pode resultar de não haver fundo comum. $\mathrm{O}$ risco que importa é o de lucros e perdas, tal como se convencionou. Se os patrimônios são individuados, as perdas também o são. Não se conceberia que o sócio participante não corresse nenhum risco de perdas, porque faltaria a affectio societatis ou seria leonina. No tocante à partilha dos lucros e das perdas, cabe ao contrato social dar as normas que se têm de observar. Se os figurantes nada estabeleceram, a quota nas perdas e nos lucros é conforme a quota nas entradas. (PONTES DE MIRANDA, Francisco Cavalcanti. Op. cit., p. 326, 328, 341).

Neste sentido vide: TJSP. Apelação n. ${ }^{\circ}$ 0066314-46.2005.8.26.0100, rel. Ricardo Negrão, j. 02.09.2013. No referido julgado, o sócio ostensivo ajuizou ação de cobrança para pleitear o pagamento de parte dos prejuízos apurados pela sociedade em conta de participação e que cabia ao sócio participante. O sócio participante alegou que os prejuízos decorreram de atos do sócio ostensivo, mas os Desembargadores acolheram os argumentos do sócio ostensivo e condenaram o sócio participante do montante do prejuízo que lhe cabia de acordo com a aplicação do percentual de sua participação na sociedade em conta de participação. In verbis: Somente o sócio ostensivo administra e somente ele assume integralmente o risco do negócio. Ao sócio oculto ou participante cabe apenas investir e participar proporcionalmente dos 
Em caso de silêncio do contrato a respeito deste tema, a interpretação mais acertada, na nossa visão, é no sentido de que a responsabilidade do sócio participante equivale à sua participação societária. ${ }^{223}$

\section{V.4 Administração da sociedade em conta de participação}

$\mathrm{Na}$ sociedade em conta de participação, a administração está intrinsecamente relacionada à figura do sócio ostensivo que, nos termos do artigo 991 do Código Civil de 2002, a exerce em seu nome individual e sob sua própria e exclusiva responsabilidade. Portanto, o sócio ostensivo atua em uma dupla função. No entanto, a função de administrador é oponível ad intra, na relação interna entre os sócios da sociedade em conta de participação. Perante terceiros, o sócio ostensivo não deverá atuar como administrador da sociedade em conta de participação, que não tem personalidade jurídica e não pode ser oponível perante terceiros.

Caso o sócio ostensivo seja uma pessoa física, a administração caberá à pessoa natural do sócio. Já nas hipóteses em o sócio ostensivo for uma pessoa jurídica,

resultados. (...) A responsabilidade dos sócios ocultos está limitada à sua participação no patrimônio especial da sociedade em conta de participação.

${ }^{223}$ A este respeito, Paulo Cavalcanti Salgado entende que: "O sócio secreto, na falta de estipulação expressa, responde pelas perdas verificadas, mesmo além da medida da quota com que entrou para o fundo social. Foi uma alteração profunda imposta ao organismo das sociedades em conta de participação pela maioria dos codigos modernos. A sociedade em conta de participação teve a sua origem na necessidade de aliviar a responsabilidade ilimitada dos sócios. Por isso o direito genovez e os jurisconsultos estabeleciam que a responsabilidade dos participantes ocultos tinha o seu limite máximo na somma com que contribuíam para a formação do capital comum. O Codigo de Commercio alemão, antigo e moderno, mantem a orientação genovesa e declara no art. 253 do antigo e 337 do em vigor, que o associado tácito não contribue para as perdas senão ate ao montante de sua quota. O nosso Código de Commercio não estabelece limitação à responsabilidade do sócio secreto, decreta pelo contrário, no art. 326, que os mesmos sócios ficam obrigados por todos os resultados das transações e obrigações sociaes, empreendidas nos termos precisos do contracto. A doutrina, com raras discreoancias, sulfraga a teoria que, no silencio do contracto, não limita a responsabilidade dos sócios ocultos ao total de sua entrada, mas a amplia ao valor proporcional da quota, pois, como diz o eminente Vivante, esta limitação que poria o sócio secreto em posição mais favorável que o ostensivo não está implícita em um contracto que tem por fim tornar comum a sorte dos contractantes. A limitação de responsabilidade é um favor excepcional concedido pela lei ao commanditario e ao acionista, mas por isso que, no caso, falta confirmação à exceção, deve aplicar-se a regra de direito comum, que chama à cada sócio a parte de perdas em proporção da quota que conferio ou dos lucros que estipulou. (SALGADO, Paulo Cavalcanti. Das sociedades em conta de participação no direito comercial brasileiro. Recife, 1913, p. 101. 
caberá ao representante legal da pessoa jurídica atuar na qualidade de administrador da sociedade de forma a representar o sócio ostensivo. ${ }^{224}$

Nos termos do artigo 1.018 do Código Civil de 2002, não é permitido que o sócio ostensivo delegue as suas funções.

Nos casos em que há mais de um sócio ostensivo em uma mesma sociedade em conta de participação, o contrato deverá indicar quem atuará perante terceiros para determinados atos e, em caso de silêncio do contrato, todos os sócios ostensivos deverão atuar perante terceiros.

Os administradores das sociedades em conta de participação deverão cumprir os requisitos previstos no artigo 1.011, § $1^{\circ}$, do Código Civil de 2002. Assim, não poderão ser administradores, além das pessoas impedidas por lei especial, os condenados a pena que vede, ainda que temporariamente, o acesso a cargos públicos; ou por crime falimentar, de prevaricação, peita ou suborno, concussão, peculato; ou contra a economia popular, contra o sistema financeiro nacional, contra as normas de defesa da concorrência, contra as relações de consumo, a fé pública ou a propriedade, enquanto perdurarem os efeitos da condenação. ${ }^{225}$

A respeito da responsabilidade do administrador, vide item acima referente à responsabilidade de sócio ostensivo de sociedade em conta de participação.

\footnotetext{
${ }^{224}$ Conforme preconiza Paulo Cavalcanti Salgado: "Os sócios podem estipular que a direcção de empresa toque a um extranho. É uma hypothese rara, pois, a responsabilidade solidaria, ilimitada do gerente pelas obrigações sociaes é uma garantia de diligente e criteriosa administração. Dado, porem, que se verifique não há como deixar de applicar as regras da comissão, pois no caso, o gerente pratica em seu nome e por conta alheia, negócios, dos associados. Um participante oculto pode administrar os negócios da sociedade, sem que perca a sua qualidade de sócio a qual não aparece aos terceiros. Basta para isto que ele receba mandato do sócio ostensivo, que relativamente aos terceiros continua como único proprietário do negocio. O sócio oculto operará, então, em nome do sócio ostensivo. É um meio de se permitir na sociedade em conta de participação o conferimento de quota de indústria da parte do sócio oculto. N'esta combinação o sócio de indústria, relativamente aos terceiros é simples locador de serviços, enquanto nas relações inter-sociaes, é um verdadeiro associado que corre os riscos do negocio feito em comum. N'estas sociedades, algumas vezes, a quota do sócio ostensivo, consiste na sua indústria. Deste modo os associados ocultos procuram aproveitar os elementos technicos, ou profissionais do sócio ostensivo, pondo-os a serviço da sociedade." (SALGADO, Paulo Cavalcanti. Op. cit., p. 92-93).

${ }^{225}$ Disponível em: <www.planalto.gov.br>. Acesso em: 30 set. 2013.
} 
O sócio que gere os negócios sociais tem a obrigação de empregar os fundos sociais para a consecução do objeto social, sob pena de responsabilização. ${ }^{226}$

Ademais, deverão os artigos 1.013, § 2 $2^{\circ}$ 1.016, caput, e 1.017, caput e parágrafo único, do Código Civil de 2002 serem aplicados às sociedades em conta de participação em caso de atuação de administradores com dolo ou culpa. ${ }^{227}$

\begin{abstract}
${ }^{226}$ A respeito da administração da sociedade em conta de participação, vide Pontes de Miranda: A administração da sociedade é entregue a um, a dois ou a mais sócios participantes ativos. Se não se previu no contrato social, qualquer sócio participante que se põe em contato com terceiros é sócio participante ativo. Quem gere tem de ter capacidade para comerciar, pois, ou já é comerciante, ou, se a sociedade em conta de participação é comercial, comerciante se torna. A Côrte de Cassação da França, a 3 de dezembro de 1890 julgou que estranho pode ser gerente. Sem razão, porque aí estaria confusão entre sócio participante ativo e gerente-preposto. O estranho seria representante do sócio participante ativo, ou dos sócios participantes ativos, e não participante ativo.

O sócio participante ativo pode tratar de outros negócios, seus ou de outrem, similares aos da sociedade em conta de participação; não, porém, causar, com isso, prejuízo à atividade participacional.

Pode haver remuneração ao sócio participante ativo, ou aos sócios participantes ativos.

O sócio participante ativo tem de se adstringir aos termos do contrato e à natureza e extensão da operação a que se refere o contrato. As relações jurídicas internas podem ser concebidas de tal maneira que, a despeito de seu, na vida jurídica, sociedade em conta de participação, haja a incidência - por força contratual - das regras jurídicas sobre as sociedades em nome coletivo ou sobre as comanditas.

Lê-se no Código Comercial, art. 333: "O sócio que, sem consentimento por escrito dos outros sócios, aplicar os fundos ou efeitos da sociedade para negócio ou uso de cinta própria, ou de terceiro, será obrigado a entrar para a massa comum com todos os lucros resultantes; e se houver perdas ou danos serão estes por sua conta particular além do procedimento criminal que possa ter lugar". O sócio que gere os negócios sociais ou tem posse de bens da sociedade não pode empregar fundos sociais em negócio jurídico sem ou em uso de conta própria, ou de terceiro. Mesmo que seja para se alimentar. Todos os ganhos têm de ser postos no ativo social. Se assim não procede o sócio, que tem a gestão, sem consentimento escrito dos outros sócios, comete ato ilícito absoluto, e não só ato ilícito relativo. Resta saber se a permissão escrita é exigida como forma essencial, ou somente como prova. A resposta é no sentido de não se poder provar por indícios ou outros meios de prova, salvo se foi feita a prova de se ter perdido o instrumento do consentimento. O sócio que infringiu o art. 333 do Código Comercial tem de entregar à sociedade os lucros obtidos com o investimento. Não pode debitar perdas e prejuízos. Da dívida, correm juros de mora. (PONTES DE MIRANDA, Francisco Cavalcanti. Op. cit., p. 341-342).

${ }^{227}$ Disponível em: <www.planalto.gov.br>. Acesso em: 30 set. 2013.
\end{abstract}

Os referidos dispositivos legais preveem que:

Art. $1.013, \S 2^{\circ}$ : Responde por perdas e danos perante a sociedade o administrador que realizar operações, sabendo ou devendo saber que estava agindo em desacordo com a maioria.

Art. 1.016: Os administradores respondem solidariamente perante a sociedade e os terceiros prejudicados, por culpa no desempenho de suas funções.

Art. 1.017: O administrador que, sem consentimento escrito dos sócios, aplicar créditos ou bens sociais em proveito próprio ou de terceiros, terá de restituí-los à sociedade, ou pagar o equivalente, com todos os lucros resultantes, e, se houver prejuízo, por ele também responderá.

Parágrafo único. Fica sujeito às sanções o administrador que, tendo em qualquer operação interesse contrário ao da sociedade, tome parte na correspondente deliberação.

A este respeito, vide também:

STJ, Recurso Especial n. ${ }^{\circ}$ 110.933, rel. Ministro Eduardo Ribeiro, j. 23.11.99. No referido julgado, há menção de que a hipótese de malogro da sociedade deveu-se à má gerência dos recursos, não sendo o caso de repartir prejuízos, mas de reconhecer o dever de indenizar de quem deu causa, culposamente, ao resultado. (...) Constituíram as partes sociedade em conta de participação e pelas normas pertinentes às sociedades em questão haveria de ser decidida. Lucros e prejuízos, em tais circunstâncias, hão de ser repartidos, com observância do acordado. (...) Ora, ficou demonstrado seguramente nos autos que o empreendimento fracassou por culpa exclusiva da recorrente. Isso se tendo verificado, cumprir-lhe-ia 
O administrador da sociedade em conta de participação está obrigado a prestar contas de sua gestão a todos os sócios. Caso as contas não sejam prestadas, não haverá efeito imediato à sociedade, tendo como consequência não iniciar a contagem do prazo decadencial de responsabilização dos administradores em relação às contas. ${ }^{228}$

A aprovação expressa ou tácita das contas libera o sócio ostensivo, que então recebe quitação pelos atos praticados como administrador da sociedade. ${ }^{229}$

Os sócios poderão prever remuneração a ser paga ao sócio que exerce a administração da sociedade.

indenizar os demais sócios. Não se trata de dividir prejuízos, mas de responder aquele que gerenciava os recursos por sua má aplicação.

${ }^{228}$ RAMIRES, Rogério. Op. cit., p. 122.

${ }^{229}$ STJ, Recurso Especial n. ${ }^{\circ}$ 23.502-2 SP, rel. Ministro Eduardo Ribeiro, j. 13.09.1993. No referido julgado, há menção ao fato de que as contas deverão ser pedidas ao sócio ostensivo que administra os fundos comuns. Sendo aquele uma pessoa jurídica, esta se acha obrigada à prestação de contas. 


\section{CAPÍTULO VI TÉRMINO DA SOCIEDADE}

O procedimento de término da sociedade em conta de participação envolve a dissolução, a liquidação e a consequente extinção da sociedade.

Neste item VI traçar-se-á o panorama geral do término das sociedades em conta de participação e tecer-se-á determinadas considerações a respeito da dissolução e liquidação da sociedade, sendo que a sua extinção ocorre de forma automática com o fim da liquidação.

\section{VI.1 Dissolução da sociedade}

Como verdadeira sociedade, dissolve-se a conta de participação pelos mesmos motivos que se dissolvem as demais sociedades, com as modificações exigidas por sua estrutura. ${ }^{230}$

Assim, uma das hipóteses que acarreta a dissolução social é o fim do prazo pactuado ou conclusão do objetivo social. A este respeito, é importante mencionar que se expirado o prazo de existência, a sociedade continua, ocorrendo uma prorrogação tácita do contrato.

Outra hipótese aventada para a dissolução da sociedade em conta de participação ocorre com a falência de sócio ostensivo. Vale ressaltar que a falência do sócio ostensivo ensejará a dissolução da sociedade em conta de participação somente se: (i) o contrato assim estipular, caso em que os haveres do sócio falido somente integrarão a massa após o pagamento de todo o passivo da sociedade, (ii) quando composta por dois sócios, um deles é extinto ou quando composta de mais de dois sócios, extingue-se o único sócio ostensivo.

\footnotetext{
${ }^{230}$ Conforme LOPES, Mauro Brandão. Ensaio sôbre a conta de participação... cit., p. 174.
} 
A dissolução da sociedade em conta de participação também ocorre por vontade de todos os sócios, ou seja, por distrato social, bem como na hipótese do instrumento de constituição da sociedade em conta de participação vier a ser considerado nulo.

A morte dos sócios ou a resolução da sociedade em relação a um sócio, salvo convenção em contrário no contrato, também enseja a dissolução da sociedade.

Ademais, quando só existem dois sócios, a morte de um deles torna inviável a continuação da sociedade e, por consequência, enseja o seu término. Da mesma forma, quando só existem dois sócios, a resolução da sociedade em relação a um deles ensejará o término da sociedade.

A respeito das disposições contratuais a respeito da continuação da sociedade diante da morte dos sócios, vale ressaltar que a sociedade poderá continuar com os herdeiros do sócio falecido ou, ainda, que o falecimento poderá ensejar a liquidação da participação do sócio falecido e o pagamento dos haveres correspondentes aos herdeiros, sendo certo que, nesta última hipótese, a morte do sócio poderá acarretar o término da sociedade na hipótese em que só existem dois sócios ou ainda na hipótese em que o falecido figurava como sócio ostensivo ou que a presença do falecido, mesmo figurando como sócio participante, era essencial para o desenvolvimento dos negócios sociais.

A affectio societatis está presente nas sociedades em conta de participação mais do que em outras sociedades. Assim, uma vez falecido o sócio ostensivo, os sócios participantes não estão obrigados a confiar em seus sucessores, que não lhes oferecem as mesmas considerações pessoais de seu antecessor.

A morte do sócio participante pode produzir, também, a dissolução da sociedade em conta de participação. A sua pessoa foi tomada em consideração para a celebração do contrato. O seu direito de fiscalização é personalíssimo e ele pode participar das deliberações sociais. 
A este respeito, SALGADO ${ }^{231}$ menciona que

a cláusula de continuação da sociedade em conta de participação entre os sócios sobreviventes, com exclusão dos herdeiros do pré-morto ou com estes herdeiros, é pela própria natureza das cousas, raras, no caso de morte do gerente, enquanto pelo contrário, muito comum para a hypothese de morte de sócio oculto.

A sociedade em conta de participação também pode ser dissolvida diante da impossibilidade de preenchimento de seu fim como, por exemplo, nas hipóteses em que a apuração de prejuízos ou a ocorrência de outro fato essencial à continuação da sociedade acarrete a inviabilidade de prosseguimento com as atividades sociais.

É importante mencionar, ainda, que há a peculiaridade de que, em determinados casos, não é possível a resolução da sociedade em relação a um único sócio, com consequente continuidade da sociedade em conta de participação. Isto ocorre na hipótese em que o sócio que tem o seu vínculo social dissolvido seja o único daquela categoria e, portanto, a resolução em relação àquele sócio ensejará a dissolução, liquidação e posterior extinção da sociedade em conta de participação.

Portanto, não se aplica à sociedade em conta de participação a hipótese prevista no artigo 1.033, inciso IV, do Código Civil de 2002 de permanência da sociedade com apenas um sócio durante um prazo determinado.

Por outro lado, e especialmente no que se refere ao sócio ostensivo, mesmo que existente outro, caso a participação daquele que se retirou da sociedade em conta de participação seja essencial, ela pode restar completamente dissolvida, tendo em vista a impossibilidade de continuar operando. A sociedade dissolve-se, neste caso, pela inexequibilidade de preenchimento do seu fim, nos termos do art. 1.034, inciso II, do Código Civil de 2002.

${ }^{231}$ SALGADO, Paulo Cavalcanti. Op. cit., p. 132. 


\title{
VI.2 Liquidação da sociedade
}

Com a dissolução, as sociedades passam à fase de liquidação. As peculiaridades da sociedade em conta de participação, porém, introduzem modificações decisivas em tal processo.

Assim, o liquidante tem que ser necessariamente o sócio ostensivo, já que os fundos sociais estão em sua esfera patrimonial. ${ }^{232}$

A este respeito, BRANDÃO LOPES ${ }^{233}$ menciona que

\begin{abstract}
Sendo de cada sócio ostensivo a propriedade dos fundos sociais em seu poder, a nomeação de um outro sócio ou de estranho como liquidante introduziria no estabelecimento um elemento de inegável incongruência; terse-ia a substituição do sócio ostensivo, no seu próprio estabelecimento, com a limitação de seus poderes quanto aos negócios da conta de participação, ou o seu afastamento no caso de participação em todo o seu comércio.
\end{abstract}

No caso das sociedades em conta de participação com vários sócios ostensivos, vários serão os liquidantes e cada um será responsável pela liquidação das operações sob sua responsabilidade.

Diante das peculiaridades da sociedade em conta de participação, especialmente diante do fato de que o sócio ostensivo necessariamente figura como liquidante, a liquidação coincide com a prestação de contas, já que o liquidante, no caso, descreverá atos próprios. ${ }^{234}$

\footnotetext{
${ }^{232}$ Uma discussão interessante é no sentido de prever que será responsável pela liquidação da sociedade em conta de participação em caso de falecimento do sócio ostensivo. A esse respeito, vale destacar o ensinamento de Paulo Cavalcanti Salgado, com o qual concordamos: "Si o sócio ostensivo falecer, a quem se deve confiar a liquidação da sociedade em conta de participação? Aos seus herdeiros. No caso de não deixar herdeiros, aplicar-se-á a disposição do art. 309 do Código Commercial, podendo a escolha recahir sobre o sócio secreto que operará como representante dos herdeiros do sócio pré-morto. Segundo a lição de Teixeira de Freitas, não cabe ao sócio secreto arrogar-se o direito de liquidar os negócios sociaes e fazer a partilha". (SALGADO, Paulo Cavalcanti. Idem, p. 145).

${ }^{233}$ LOPES, Mauro Brandão. Ensaio sôbre a conta de participação... cit., p. 180.

${ }^{234}$ A este respeito, convém destacar os ensinamentos de Paulo Cavalcanti Salgado no sentido de que: "Os sócios podem convencionar a restituição das causas com que entram para a sociedade, depois que se dissolver o vínculo social. Este facto, porem, por força obrigatória relativamente aos terceiros para quem é res inter alios acta. Déste modo, si o sócio ostensivo alienar o bem gravado d'esta clausula, não tem o participante oculto, acção de reinvindicação contra o terceiro adquirente mas somente acção de indemnização contra o sócio ostensivo. O participante oculto pode obter como garantia dos seus direitos
} 
A respeito da discussão a respeito da forma de dissolução e liquidação da sociedade em conta de participação, vide as seguintes decisões judiciais descritas no Anexo II a este trabalho: TJSP, Apelação Cível n. ${ }^{\circ}$ 108.697, rel. Des. Euler Bueno, j. 14.09.1961; TJSP, Agravo de Instrumento n. ${ }^{\circ}$ 0096478-90.2011.8.26.0000, rel. Des. Luiz Antonio Costa, j. 18.04.2012; TJSP, Apelação n. ${ }^{\circ}$ 9100389-59.2008.8.26.0000, rel. Des. Luiz Ambra, j. 11.04.2012; TJRJ, Apelação Cível n. ${ }^{\circ}$ 3630/96. rel. Des. Asclepíades Rodrigues, j. 06.08.1996; TJRJ, Apelação Cível n. ${ }^{\circ}$ 000211044.2008.8.19.0209, rel. Des. Luiz Felipe Francisco, j. 22.06.2010; TJRJ, Apelação Cível n. ${ }^{\circ}$ 0003466-02.2007.8.19.0212, rel. Des. Paulo Mauricio Pereira, j. 29.08.2012; STJ, Resp. n. ${ }^{\circ}$ 474.704, rel. Ministro Carlos Alberto Menezes, j. 17.12.2002, STJ, Resp n. ${ }^{\circ}$ 472.803, rel. Ministro Aldir Passarinho Junior, 20.11.2008; STF, Recurso Extraordinário n. ${ }^{\circ}$ 17.586, rel. Ministro Afrânio Antonio da Costa, j. 20.04.1951.

A este respeito, TAVARES GUERREIRO ${ }^{235}$ analisou acórdão ${ }^{236}$ paradigmático sobre o tema. A decisão judicial analisada pelo ilustre professor admite a dissolução da sociedade em conta de participação por entender que não há óbice em fazê-la, ainda que a prestação de contas seja a forma mais discreta.

No referido caso concreto, todos os sócios buscavam, ainda que de forma diversa, o mesmo objetivo: a dissolução de sociedade em conta de participação constituída para exploração de posto de gasolina e de lanchonete.

A decisão foi no sentido de que a sociedade deveria ser dissolvida e que a posterior liquidação deveria ser realizada mediante prestação de contas pelo sócio ostensivo.

TAVARES GUERREIRO afirmou que a decisão é rica, já que admite o procedimento dissolutório para o fim de desconstituir sociedade não personificada e, assim, admite que os vínculos instituidores da sociedade de conta em participação

empenhados na sociedade em conta de participação, uma hypotheca, fiança ou penhor em bens do sócio ostensivo." (SALGADO, Paulo Cavalcanti. Das sociedades em conta de participação... cit., p. 86)

${ }^{235}$ GUERREIRO, José Alexandre Tavares. Sociedade Comercial - Conta de participação - Dissolução Possibilidade de recurso ao Judiciário. Revista de Direito Mercantil, Industrial, Econômico e Financeiro, n. ${ }^{\circ}$ 54, São Paulo, RT, abr.- jun. 1984, p. 126-130.

${ }^{236}$ TJSP, Apelação Cível n. ${ }^{\circ}$ 33.773-2, rel. Des. Tomaz Rodrigues, j. 10.03.1983. 
identificam uma relação jurídica essencialmente diversa daquela que emana do contrato bilateral.

O referido professor afirma, ainda que, na medida em que entende como cabível a ação de dissolução de sociedade, a decisão conduz à "liquidação" os rumos da demanda, ainda que sob a forma de "prestação de contas através de prevalente iniciativa do sócio ostensivo".

A decisão pretoriana tradicional invocada no texto repele a liquidação e partilha do patrimônio social. O Professor afirma que esta peculiaridade não desnatura o caráter societário da sociedade em conta de participação e não a reduz a mero contrato bilateral em que "as relações entre os sócios se liquidam por ajuste de contas ou prejuízos de negócios empreendidos”.

Ainda em relação à liquidação da sociedade em conta de participação, BRANDÃO $\operatorname{LOPES}^{237}$ afirma que

\begin{abstract}
Os sócios ocultos em relação a todos os ostensivos, e estes em relação uns aos outros, podem, nas prestações de contas exigir que o sócio ostensivo os indenizem dos capitais que serviram para pagamento dos credores particulares do gerente, assim como apurarão todas as responsabilidades do sócio gerente, durante a administração e liquidação dos negócios comuns, como falta de fiscalização dos empregados, desvios de somas, não produção de crédito social na falência de um devedor etc.
\end{abstract}

Conforme exposto acima, a respeito da forma da liquidação da sociedade em conta de participação via prestação de contas, determinados juristas utilizam esta peculiaridade para afirmar que este fato enseja a sua classificação como contrato e não como sociedade.

No entanto, não concordamos com este posicionamento e filiamo-nos à vertente defendida por GUERREIRO, ${ }^{238}$ que menciona:

\footnotetext{
${ }^{237}$ LOPES, Mauro Brandão. Ensaio sôbre a conta de participação... cit., p. 184.

${ }^{238}$ GUERREIRO, José Alexandre Tavares. Sociedade Comercial - Conta de participação - Dissolução Possibilidade de recurso ao Judiciário. Revista de Direito Mercantil, Industrial, Econômico e Financeiro, n. ${ }^{\circ}$ 54, São Paulo, RT, abr.- jun. 1984, p. 126-130.
} 
Estamos em que essa peculiaridade não desnatura o caráter societário da sociedade em conta de participação e não a reduz a mero contrato bilateral em que 'as relações entre os sócios se liquidam por ajuste de contas ou prejuízos de negócios empreendidos’. Mais que o modus procedimental da apuração de haveres, ou que sua designação formal, importa a realidade da existência de fundos sociais.

A liquidação da sociedade em conta de participação pode ser realizada de forma extrajudicial ou judicial, esta última em conformidade com o disposto nos artigos 914 a 919 do Código de Processo Civil. ${ }^{239}$

Tendo em vista o fato de que, nos termos do artigo 992 do Código Civil de 2002, a constituição da sociedade em conta de participação independe de qualquer formalidade, a extinção da referida sociedade também pode ocorrer independente de qualquer formalidade.

\footnotetext{
${ }^{239}$ A este respeito, é importante mencionar que Waldemar Ferreira defende que não é possível a liquidação judicial da sociedade em conta de participação. In verbis: "não cabe a liquidação judicial. (...) A liquidação judicial é processo por via do qual se inventariam os bens constituintes do patrimônio social, cobram-se as dívidas ativas, pagam-se as dívidas passivas, praticam-se os atos assecuratórios dos direitos da sociedade, vendem-se os bens sociais e, liquidando todo o passivo, partilha-se o resíduo entre os sócios". (FERREIRA, Waldemar. Tratado de sociedades mercantis... cit., p. 518-521).

Brandão Lopes entende que: "Tem razão o grande mestre se se entender que a forma final da liquidação da conta de participação é a prestação de contas do sócio ostensivo, mas não me parece de deva tirar dêsse fato a conclusão de que é impossível a liquidação judicial; antes, a conclusão se impõe, a meu ver, é que, na impossibilidade de liquidação amigável, a judicial toma necessariamente a forma de prestação de contas, pedidas ao sócio ostensivo. (...) Quanto à liquidação da conta de participação que tem vários sócios ostensivos, o primeiro ponto a observar é que o processo, embora tome a forma de prestação de contas, é na verdade uma real liquidação de sociedade. Assim, concluo que um sócio ostensivo não poderá pedir judicialmente a liquidação, por meio das prestaçães de contas dos demais sócios ostensivos sem que preste êle próprio de imediato as suas próprias contas, porque isso equivaleria a pedir uma liquidação parcial. A liquidação judicial da conta de participação toma assim a forma de ação proposta contra todos os sócios ostensivos para que prestem as contas de suas gestões, e, quando iniciada por sócio ostensivo, terá ele de oferecer desde logo as contas de sua própria gestão". (LOPES, Mauro Brandão. Ensaio sôbre a conta de participação... cit., p. 185).

E, ainda, Waldirio Bulgarelli cita Acórdão (TJSP, Apelação n. ${ }^{\circ}$ 47.518, rel. Des. Fernandes Martins, j. 09.07.1950) no sentido de que: "A liquidação das sociedades, especialmente a mercantil, tem fórma solêne e específica de liquidar-se, por ser, em regra, concurso creditório; e a lei processual the deu rito especial em prol dos interesses de terceiros, na liquidação envolvidos. A sociedade em conta de participação, entretanto, não tem, não pode ter credores, pela razão muito simples de que ela não se obriga, não pode obrigar-se, nem tem patrimônio próprio, de modo que não seria nenhum paradoxo asseverar que ela, nas relações com terceiros, não existe. O que existe é o sócio ostensivo, pessoa natural ou jurídica, que opéra sob sua firma individual ou social, ou sob sua denominação, quando a tenha. Tal negociante ou qual sociedade é que negocia, $\mathrm{O}$ outro, ou os outros sócios, como participantes, permanecem na penumbra. Não se compreende, por isso mesmo, a liquidação de tal sociedade por qualquer das fórmas por quê as demais sociedades se liquidam. Mais não cabe ao sócio participante do que reclamar a sua parte nos lucros do negócio para cuja realização se associou ao comerciante ou à sociedade. Razão é essa por quê muitos doutrinam que tal sociedade não tem natureza societária., mas simples natureza contratual, não passando de puro e simples contrato de participação de lucros em certo e determinado negócio. A liquidação da sociedade em conta de participação, em tais termos, pode resumirse em simples prestação de contas, amigável ou judicialmente." (BULGARELLI, Waldirio. Sociedades, empresa e estabelecimento. São Paulo: Atlas, 1980. p. 147).
} 
Assim, uma sociedade em conta de participação constituída por meio de instrumento público pode ser extinta por meio de instrumento particular, por exemplo.

Além disto, não é obrigatória que a extinção da sociedade em conta de participação ocorra por escrito, ainda quando a sociedade tenha sido constituída por escrito. $^{240}$

${ }^{240}$ Conforme FERREIRA, Waldemar. Tratado de sociedades mercantis... cit., p. 518-521. 


\section{CAPÍtUlo VII FUNÇÃo E PRÁTICA DAS SOCIEDADES EM CONTA DE PARTICIPAÇÃO}

\section{VII.1 Considerações iniciais}

Conforme já mencionado no Capítulo II, as sociedades em conta de participação surgiram na Idade Média como forma de viabilizar investimentos, bem como para possibilitar o exercício do comércio por nobres que consideravam o seu exercício uma prática vexatória. Ademais, a sociedade em conta de participação também era utilizada, em determinadas ocasiões, para burlar a proibição imposta pela Igreja Católica referente à condenação da usura proveniente do comércio.

Com o decorrer dos tempos, a sociedade em conta de participação continuou a ser utilizada como instrumento apto a formalizar investimentos e estruturar as relações entre partes interessadas em um determinado negócio. ${ }^{241}$

Este Capítulo tem por objetivo analisar as funções das sociedades em conta de participação nos dias atuais.

Tendo em vista que, nos termos do artigo 992 do Código Civil de 2002, a constituição da sociedade em conta de participação independe de formalidade e pode provar-se por todos os meios de direito e, ainda, que o artigo 993 do Código Civil de

\footnotetext{
${ }^{241}$ A este respeito, Waldirio Bulgarelli afirma: "O Prof. Oscar Barreto Filho entendia que a sociedade em conta de participação era a forma associativa, dentro dos quadros do direito vigente, que melhor se prestar para traduzir em termos jurídicos a atividade desenvolvida pelos investments trusts do tipo aberto (openend). Também Waldemar Ferreira, além das sociedades de investimentos (fundos de acceptance) como sociedades em conta de participação, também considerava o contrato de royalties como dessa natureza. A maioria dos autores aponta os sindicatos financeiros (Pontes de Miranda, Dídimo da Veiga etc.) como sociedades em conta de participação. Aliás, Pontes de Miranda relaciona uma série de atividades negociais que podem ser exercidas e em muitos casos o são, sob a forma de sociedade em conta de participação, como a gestão ou controle de produtos ou de vendas - cartes, konzern; na exploração de imóveis, a indústria jornalística, obras públicas, na compra para corte e divisão posterior de pedras preciosas por lapidadores, apenas exteriorizando-se um entre eles. Também entre nós ficaram equiparadas às sociedades em conta de participação (arts. 325 a 328 do Código Comercial) as sociedades não acionárias de pluriparticipação, referidas pelo art. $1^{\circ}$, § único, n..$^{\circ}$ II, do Decreto-lei n..$^{\circ} 1.134$, de 16-111970, consoante o art. 16 do Decreto n. ${ }^{\circ}$ 68.565, de 29-04-1971 - legislação essa que se refere a incentivos fiscais para aplicação em empreendimentos florestais. Portanto, são inumeráveis as utilizações de que a sociedade em conta de participação pode revestir-se na prática. (BULGARELLI, Waldirio. Op. cit., p. 137-138.)
} 
2002 prevê que a eventual inscrição do instrumento de constituição não confere personalidade jurídica à sociedade, conclui-se que não é praxe o registro de documentos que formalizam este tipo societário em cartórios de títulos e documentos e/ou nos órgãos de registro de comércio.

Por esta razão, a verdade é que nos deparamos com certa dificuldade de obter informações a respeito do real alcance e utilização deste tipo societário e, também, a respeito das formas mais usuais de utilização da sociedade em conta de participação.

De toda forma, ainda que o levantamento esteja longe de ser exaustivo e abrangente o suficiente para que se obtenha uma conclusão a respeito das práticas das sociedades em conta de participação, realizamos buscas na Junta Comercial do Estado de São Paulo, ${ }^{242}$ o que possibilitou a obtenção de um dado interessante, que reforça a utilidade deste estudo.

Isso porque a busca na Junta Comercial do Estado de São Paulo demonstrou a existência de 14 (quatorze) sociedades em conta de participação, conforme quadro abaixo. $^{243}$

\footnotetext{
${ }^{242}$ As tentativas de buscas limitaram-se às Juntas Comerciais dos Estados de São Paulo, Rio de Janeiro, Minas Gerais e Rio Grande do Sul. É importante esclarecer que não foi possível obter resultados esclarecedores nas Juntas Comerciais dos Estados de Minas Gerais, Rio de Janeiro e Rio Grande do Sul. Isso porque as classificações de registro do referido órgão de registro do comércio apenas dizem respeito a registro de empresário, sociedade limitada, sociedade por ações, cooperativa, Empresa Individual de Responsabilidade Limitada - EIRELI e Outros. Portanto, os eventuais arquivamentos de atos constitutivos de sociedades em conta de participação estariam alocados na classificação "outros", o que inviabiliza a obtenção de dados mais específicos a esse respeito. Ademais, as tentativas de contato direto com os respectivos órgãos de registro do comércio não resultaram em conclusões frutíferas para os fins desta dissertação.

${ }^{243}$ Quadro disponível em: <www.jucesp.sp.gov.br>. Acesso em: 17 jan. 2013.
} 


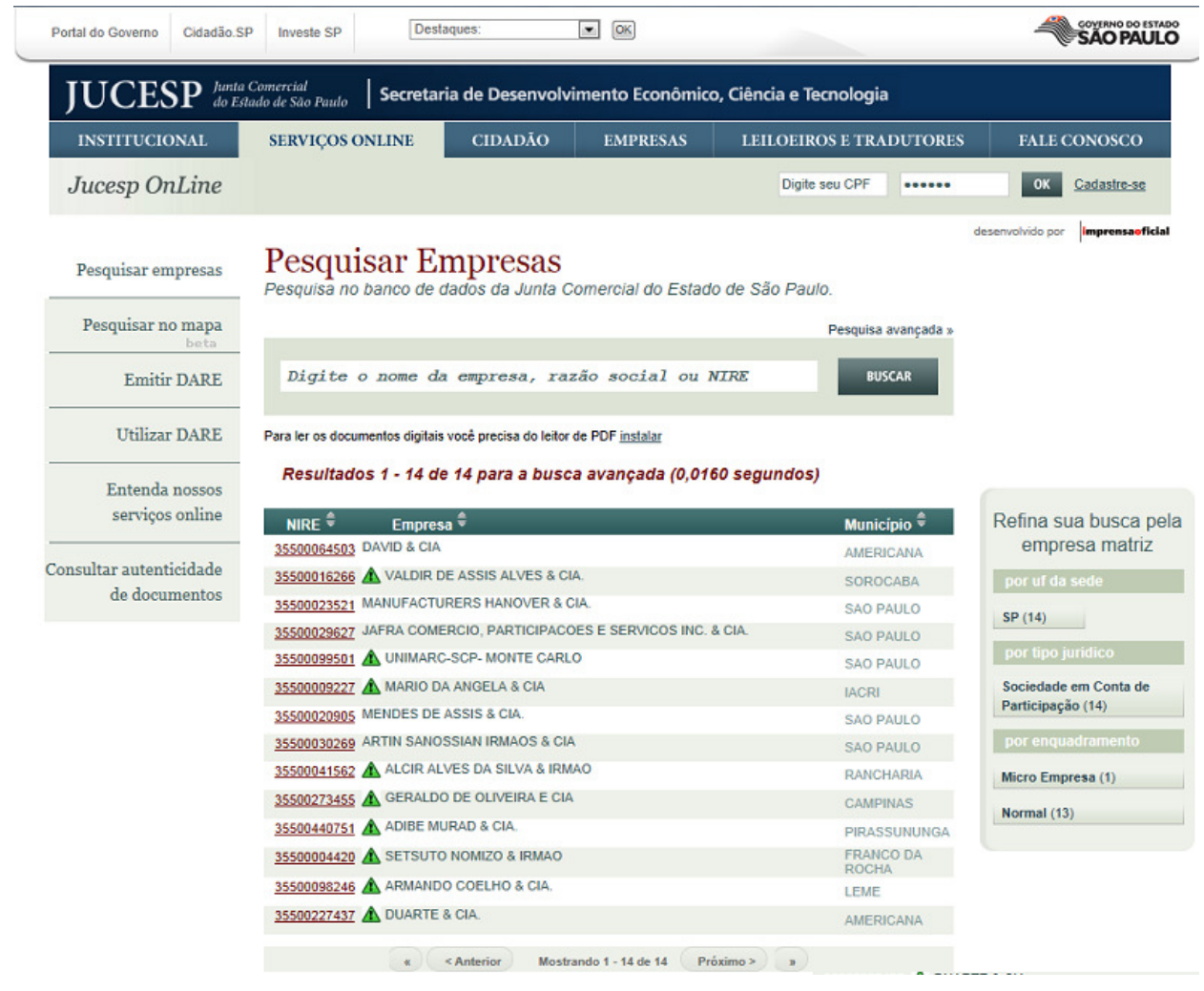

No entanto, ao analisar as fotocópias dos documentos societários das sociedades mencionadas, foi possível concluir que, conforme refletido no quadro abaixo, 13 (treze) das 14 (quatorze) sociedades cadastradas na Junta Comercial do Estado de São Paulo - JUCESP - como sociedade em conta de participação são, na realidade, sociedades em nome coletivo.

\section{Quadro - Informações JUCESP}

\begin{tabular}{|c|c|}
\hline "Denominação social & Tipo societário \\
\hline 1. David \& Cia & Sociedade em nome coletivo \\
\hline 2. Valdir de Assis Alves \& Cia & Sociedade em nome coletivo \\
\hline 3. Manufactures Hanover \& Cia. & Sociedade em nome coletivo \\
\hline $\begin{array}{l}\text { 4. Jafra Comércio, Participações e Serviços Inc. \& } \\
\text { Cia. }\end{array}$ & Sociedade em nome coletivo \\
\hline 5. Unimarc-SCP- Monte Carlo & $\begin{array}{l}\text { Sociedade em conta de } \\
\text { participação }\end{array}$ \\
\hline 6. $\quad$ Mario da Angela \& Cia. & Sociedade em nome coletivo \\
\hline
\end{tabular}




\begin{tabular}{||l||l||}
\hline 7. $\quad$ Mendes de Assis \& Cia. & Sociedade em nome coletivo \\
\hline \hline 8. $\quad$ Artin Sanossian Irmãos e Cia. & Sociedade em nome coletivo \\
\hline \hline 9. Alcir Alves da Silva \& Irmão & Sociedade em nome coletivo \\
\hline \hline 10. Geraldo de Oliveira \& Cia. & Sociedade em nome coletivo \\
\hline \hline 11. Adibe Murad \& Cia. & Sociedade em nome coletivo \\
\hline 12. Setsuto Nomizo \& Irmão & Sociedade em nome coletivo \\
\hline 13. Armando Coelho \& Cia. & Sociedade em nome coletivo \\
\hline \hline 14. Duarte \& Cia. & \\
\hline \hline
\end{tabular}

Este fato, ao que parece, decorre da ignorância, inclusive dos órgãos de registro do comércio, quanto à existência e às principais características das SCPs, o que enseja a confusão deste tipo societário com os outros tipos societários previstos na legislação vigente.

Além disto, na tentativa de se obter informações a respeito da utilização prática deste tipo societário, foi organizada diligência ao Centro de Estudos e Distribuição de Títulos e Documentos de São Paulo. No entanto, o referido órgão informou que não é possível efetuar o levantamento abstrato de todas as sociedades em conta de participação registradas. Diante disto, esta tentativa não logrou sucesso.

É sabido que as sociedades em conta de participação são muito utilizadas para estruturar negócios imobiliários. Por esta razão, o subitem VII.2 abordará este tema. Já os itens VII.3 e VII.4 abordarão outras formas de utilização de sociedades em conta de participação, a saber, para formalizar projetos florestais e para formalizar outros tipos de joint venture.

\section{VII.2 Estruturação jurídica de negócios imobiliários via utilização de sociedade em conta de participação}

\section{VII.2.1 Empreendimentos imobiliários}

A prática hodierna das sociedades em conta de participação também envolve a utilização deste tipo societário para estruturar empreendimentos imobiliários. 
Nesta hipótese, muitos casos envolvem a figura da construtora como sócia ostensiva e responsável por todo o gerenciamento das obras civis. O sócio participante, por sua vez, seria o proprietário do imóvel e/ou do terreno no qual as obras civis serão implementadas e/ou, ainda, o investidor que tem a intenção de aportar recursos para, futuramente, aferir resultados (lucros ou prejuízos) e/ou até mesmo parte ou a integralidade do imóvel em questão.

No caso dos empreendimentos imobiliários, as vantagens para os contratantes da sociedade em conta de participação (construtora e proprietário do imóvel ou investidor) tornam esta modalidade especialmente atrativa em diversos casos.

Isto porque a construtora, na qualidade de sócia ostensiva, pode tornar o seu negócio viável com menos burocracia ao receber injeção de recursos sem que, para tanto, precise: (i) destinar parte das quotas representativas de seu capital social a um terceiro investidor e (ii) registrar documentos em órgãos de registro de comércio.

A estrutura facilitada das sociedades em conta de participação podem trazer vantagens e possibilitar negócios com investidores que desejam aportar recursos em um determinado negócio, mas não desejam vincular-se, perante terceiros, com a construtora e/ou com terceiros.

Ademais, certamente uma vantagem da utilização das sociedades em conta de participação para estruturar negócios imobiliários diz respeito aos aspectos tributários envolvidos.

Isto porque a sociedade em conta de participação pode adotar regime tributário distinto do adotado pela sócia ostensiva.

Por exemplo, caso uma determinada sociedade limitada esteja impedida de optar pelo lucro presumido em função do seu volume de faturamento, a referida sociedade poderá constituir uma sociedade em conta de participação com outra pessoa 
física ou jurídica, sendo certo que a sociedade em conta de participação poderá adotar regime tributário do lucro presumido. ${ }^{244}$

São comuns os negócios imobiliários que envolvem o aporte, pelo sócio participante, de recursos ao fundo social da sociedade em conta de participação. A sócia ostensiva seria a construtora responsável pela aquisição do terreno e pelas obras e, em contrapartida à sua posição, recebe comissão que pode ser fixada no instrumento de constituição da sociedade em conta de participação. Assim que concluída a obra, o imóvel é transferido, pelo mesmo valor dos aportes realizados, ao sócio participante via dissolução e liquidação da sociedade em conta de participação com consequente transferência da propriedade do imóvel para a esfera patrimonial do sócio participante.

Com isto, além dos aspectos tributários, a vantagem reside no fato e que, até a conclusão das obras civis, a construtora (sócia ostensiva) responderá perante terceiros por todas e quaisquer obrigações da obra civil e da sociedade em conta de participação, já que a sociedade em conta de participação não assume obrigações perante terceiros, sendo certo que cabe ao sócio ostensivo fazê-lo. ${ }^{245}$

\section{VII.2.2 Utilização de sociedades em conta de participação como estrutura jurídica apta a formalizar pools hoteleiros e flats}

Atualmente, as sociedades em conta de participação são bastante utilizadas na exploração de pools hoteleiros ou flats. Usualmente, nestes casos, a sociedade

\footnotetext{
244 Conforme Instrução Normativa n. ${ }^{\circ}$ 31, da SRF, de 29 de março de 2001. A referida Instrução Normativa prevê o quanto segue: "Art. $1^{\circ}$. A partir de $1^{\circ}$ de janeiro de 2001 , observadas as hipóteses de obrigatoriedade de observância do regime de tributação com base no lucro real previstas no art. 14 da Lei $\mathrm{n}^{\circ}$ 9.718, de 27 de novembro de 1998, as sociedades em conta de participação podem optar pelo regime de tributação com base no lucro presumido. $\$ 1^{\circ}$ A opção da sociedade em conta de participação pelo regime de tributação com base no lucro presumido não implica a simultânea opção do sócio ostensivo, nem a opção efetuada por este implica a opção daquela. $\S 2^{\circ} \mathrm{O}$ recolhimento dos tributos e contribuições devidos pela sociedade em conta de participação será efetuado mediante a utilização de Darf específico, em nome do sócio ostensivo. Art. $2^{\circ}$. As sociedades em conta de participação que exerçam as atividades de compra e venda, loteamento, incorporação e construção de imóveis não poderão optar pelo lucro presumido enquanto não concluídas as operações imobiliárias para as quais haja registro de custo orçado. Art. $3^{\circ}$. O disposto nesta Instrução Normativa não prejudica a observância das demais normas relativas ao regime de tributação com base no lucro presumido previstas na legislação tributária, inclusive quanto à adoção do regime de caixa."

${ }^{245}$ Com exceção do previsto no artigo 993, parágrafo único, do Código Civil de 2002 que prevê que: "Sem prejuízo do direito de fiscalizar a gestão dos negócios sociais, o sócio participante não pode tomar parte nas relações do sócio ostensivo com terceiros, sob pena de responder solidariamente com este pelas obrigações em que intervier." (Disponível em: <www.planalto.gov.br>. Acesso em: 20 mar. 2013.)
} 
hoteleira que administra o negócio é a sócia ostensiva, enquanto que os proprietários dos imóveis que compõe o edifício são sócios participantes. ${ }^{246}$

Assim, no chamado pool hoteleiro, uma sociedade especializada na administração de bens de terceiros contrata, na condição de sócia ostensiva, uma sociedade em conta de participação com os proprietários de apartamentos e condôminos de um edifício, que se obrigam na qualidade de sócios participantes e que destinam o imóvel de sua propriedade à exploração hoteleira.

A porção do fundo social que cabe aos sócios participantes é integralizada pela transferência, a título de uso, dos apartamentos de sua propriedade, os quais são locados para terceiros pela sócia ostensiva. A sócia ostensiva, por sua vez, contribui com sua expertise na administração de flats e pool hoteleiros, que envolve a aquisição de móveis e equipamentos, a contratação de funcionários, a exploração de serviços de condomínio, bem como a locação das unidades.

Neste caso, as receitas da sociedade em conta de participação são provenientes de aluguéis dos apartamentos, bem como dos serviços prestados pelo flat, tais como serviços de alimentação, lavanderia, dentre outros. Os lucros aferidos pela sociedade em conta de participação são, então, divididos entre a sócia ostensiva e os sócios participantes, nos termos firmados entre eles no ato constitutivo da sociedade em conta de participação.

Ainda a este respeito, é importante mencionar que a Lei n. ${ }^{\circ} 11.771$, de 17 de setembro de 2008 dispõe sobre a política nacional de turismo e define as atribuições do Governo Federal Brasileiro no planejamento, desenvolvimento e estímulo ao setor turístico.

\footnotetext{
${ }^{246}$ Segundo relatório do Instituto Brasileiro de Geografia e Estatística - IBGE -, os apart-hotéis e flats representam cerca de 3,2\% (três inteiros e vinte centésimos por cento) dos meios de hospedagem disponíveis no Brasil. No que se refere à divisão dos meios de hospedagem de acordo com a categoria luxo/superior, os apart-hotéis e flats representam $41,5 \%$ (quarenta e um inteiros e cinco décimos por cento) dos meios de hospedagem existentes no Brasil (conforme Pesquisa de Serviços de Hospedagem 2011. Disponível em: <www.turismo.gov.br>. Acesso em: 14 jan. 2013).
} 
A referida lei elenca os flats dentre os meios de hospedagem fiscalizados e regulamentados pelo Ministério do Turismo e, por esta razão, os referidos pools hoteleiros devem ser cadastrados no Ministério do Turismo.

Nos termos do artigo 24, inciso II, "b", da Lei n. ${ }^{\circ}$ 11.771, de 17 de setembro de 2008, para obter o cadastramento, os empreendimentos ou estabelecimentos conhecidos como condomínio hoteleiro, flat, flat-hotel, hotel-residence, loft, apartservice condominial, condohotel e similares devem apresentar ao Ministério do Turismo, quando o caso, documento ou contrato de formalização de constituição do pool de locação, como sociedade em conta de participação, ou outra forma legal de constituição, com a adesão dos proprietários de pelo menos $60 \%$ (sessenta por cento) das unidades habitacionais à exploração hoteleira do empreendimento. ${ }^{247}$

Tendo em vista a obrigatoriedade de cadastro dos flats como meio de hospedagem junto ao Ministério do Turismo do governo brasileiro, foi possível obter informações e dados a este respeito.

A tabela que consta no Anexo I deste trabalho contém a relação de flats cadastrados perante o Ministério do Turismo do governo federal do Brasil. ${ }^{248}$

Ocorre que as informações que o Ministério do Turismo disponibilizou dizem respeito apenas a sociedades limitadas e empresários individuais que exploram flats. Possivelmente as sociedades e empresários elencados no Anexo I devem figurar como sócios ostensivos de sociedades em conta de participação.

Dentre as vantagens de se constituir uma sociedade em conta de participação cujo objeto é a exploração de flat ou pool hoteleiro, é possível citar a atribuição da gestão hoteleira ao sócio ostensivo, que em diversos casos possui a expertise para tanto.

\footnotetext{
${ }^{247}$ Disponível em: <www.planalto.gov.br>. Acesso em: 10 jan. 2013.

${ }^{248}$ Dados obtidos mediante contato com o Ministério do Turismo. Os dados estão atualizados até 17 de janeiro de 2013, data do recebimento das informações.
} 
Ademais, os sócios participantes não se responsabilizam perante terceiros, inclusive perante os locatários e perante o Ministério do Turismo, órgão que regulamenta o setor. Todas as obrigações e responsabilidades perante terceiros são assumidas pelo sócio ostensivo. Até por esta razão, em contato com o Ministério do Turismo apenas obtivemos informações a respeito dos possíveis sócios ostensivos das sociedades em conta de participação. ${ }^{249}$

O Ato Declaratório Interpretativo SRF n. ${ }^{\circ}$ 14, de 4 de maio de 2004, emitido pela Secretaria da Receita Federal, dispõe sobre a tributação das atividades do sistema de locação conjunta de unidades imobiliárias denominado pool hoteleiro. ${ }^{250}$

De acordo com o referido Ato Declaratório Interpretativo, no sistema de locação conjunta de unidades imobiliárias denominado de pool hoteleiro, constitui, independente de qualquer formalidade, sociedade em conta de participação com o objetivo de lucro comum, onde a administradora (empresa hoteleira) é a sócia ostensiva e os proprietários das unidades imobiliárias integrantes do pool são os sócios participantes.

A respeito dos aspectos tributários dos pools hoteleiros, o referido dispositivo legal prevê que as sociedades em conta de participação são equiparadas às pessoas jurídicas pela legislação do Imposto de Renda, e, como tais, são contribuintes do Imposto de Renda das Pessoas Jurídicas (IRPJ), da Contribuição Social sobre o

\footnotetext{
${ }^{249}$ A respeito da responsabilidade dos sócios participantes em sociedades em conta de participação constituídas para o fim de viabilizar flats, vide acórdão do Superior Tribunal de Justiça, $4^{\mathrm{a}}$ turma, Resp n. ${ }^{\text {o }}$ 168.028/SP, r. Ministro Cesar Asfor Rocha, j. 07.08.2001.

No caso, o autor/recorrente, Sr. Eros Roberto Grau, promoveu contra Qualitá Indústria e Comércio de Móveis Ltda. medida cautelar de sustação de protesto e ação de rito sumaríssimo declaratória de inexigibilidade de título de crédito e alegou que jamais firmara qualquer negócio com a ré/recorrida. A ré/recorrida alegou que o título de crédito foi emitido em razão de ela ter prestado serviços de fornecimento de mobília para duas unidades de propriedade do recorrente no Condomínio Edifício Morumbi Business Apart Hotel. Os serviços teriam sido contratados por Conceito Assessoria e Hotelaria, sócia ostensiva da sociedade em conta de participação também integrada pelo autor/recorrente e outros proprietários das demais unidades de referido flat, que figuravam como sócios participantes.

Na decisão, proferida ainda sob a égide do Código Comercial, os Ministros pronunciaram entendimento no sentido de que "Na sociedade em conta de participação, o sócio ostensivo é quem se obriga para com terceiros pelos resultados das transações e das obrigações sociais, realizadas ou empreendidas em decorrência da sociedade, nunca o sócio participante ou oculto que nem é conhecido dos terceiros e nem com estes trata.". Desta forma, o recurso apresentado pelo Sr. Eros Roberto Grau foi conhecido e provido. No mesmo sentido, vide STJ - Resp n. ${ }^{\circ}$ 192.603/SP, rel. Ministro Barros Monteiro, j. 15.04.2004.

${ }^{250}$ Disponível em: <www.receita.fazenda.gov.br>. Acesso em: 10 jan. 2013.
} 
Lucro Líquido (CSLL), da Contribuição para o PIS/Pasep e da Contribuição para o Financiamento da Seguridade Social (Cofins).

O Ato Declaratório Interpretativo SRF n. ${ }^{\circ}$ 14, de 4 de maio de 2004 prevê, no $\S 2^{\circ}$ do artigo único que: (i) na apuração das bases de cálculo do imposto e das contribuições referidas acima, devidas pela aludida sociedade, bem como na distribuição dos lucros, deverão ser observadas as normas aplicáveis às pessoas jurídicas em geral, (ii) são receitas ou resultados próprios da sociedade em conta de participação, exemplificativamente, sujeitando-se às normas de tributação específicas do IRPJ, da CSLL, da Contribuição para o PIS/Pasep e da Cofins: as diárias, semanadas ou aluguéis, relativos às unidades integrantes do pool hoteleiro, inclusive de áreas de restaurantes, salão de convenções, lojas, etc., também integrantes do sistema de locação conjunta; os preços dos serviços prestados, os impostos e taxas incidentes sobre os imóveis, e os demais encargos locatícios, se cobrados, pela administradora, destacadamente das diárias, semanadas ou aluguéis; as indenizações recebidas por extravios e danos causados às unidades; as multas e juros de mora; o resultado das aplicações dos saldos financeiros da sociedade, (iii) a administradora (empresa hoteleira), na qualidade de sócia ostensiva, é a responsável pelo recolhimento do imposto e das contribuições devidas pela sociedade em conta de participação, sem prejuízo do recolhimento do imposto e das contribuições incidentes sobre suas próprias receitas ou resultados, (iv) deverão ser observadas as demais normas específicas da legislação do imposto de renda e das contribuições sociais, aplicáveis às sociedades em conta de participação. ${ }^{251}$

Ainda no que se refere aos aspectos tributários inerentes à constituição de sociedade em conta de participação para exploração de pools hoteleiros e flats, é importante mencionar a discussão jurisprudencial existente a respeito da eventual incidência do Imposto Sobre Serviços de Qualquer Natureza - ISS - em caso de sociedades em conta de participação que exploram flats.

A principal discussão a respeito refere-se à eventual incidência do ISS em caso de exploração de flats, já que o Município de São Paulo exigia o referido tributo

${ }^{251}$ Disponível em: <www.planalto.gov.br>. Acesso em: 10 jan. 2013. 
com base na Portaria SF n. ${ }^{\circ} 83$, de 30 de dezembro de 1995, emitida pela Secretaria das Finanças do Município de São Paulo. O Município de São Paulo enquadrava os sócios ostensivos das sociedades em conta de participação como prestadores de serviços de hospedagem sujeitos ao pagamento do ISS.

Neste sentido, há diversos julgados que discutem a matéria. Como exemplo, mencionamos a Apelação n. ${ }^{\text {o } 794.523-5, ~ j . ~ 22.03 .2000 . ~}{ }^{252}$

${ }^{252}$ TJSP - Apelação n. ${ }^{\circ} 794.523-5$, j. 22.03.2000. A referida apelação foi interposta pela Riema Empreendimentos Imobiliários Ltda. ("Riema") contra decisão proferida no sentido da exigibilidade do ISS em caso de exercício de atividade de flat. A Riema alegou que as atividades desenvolvidas pelas sociedades em conta de participação são relacionadas à locação de bens imóveis e que não se equipara ao contrato de hospedagem. A Riema alegou, ainda: (i) que o condomínio, através de seus funcionários, é que oferecem aos proprietários ou moradores os serviços básicos ou obrigatórios previstos na convenção condominial; (ii) a inconstitucionalidade e a ilegalidade da Portaria SF n. ${ }^{\circ}$ 83, de 30 de dezembro de 1995 por estabelecer novo código de serviço para enquadrar as atividades de hospedagem realizadas em flats, apart-services e congêneres. Por maioria de votos, os Desembargadores negaram provimento ao recurso, pois entenderam, em suma, que a apelante exerce, não somente as atividades de locação de bens imóveis, mas também a prestação de serviços de hospedagem e demais serviços adicionais, dentre os quais telefonia, governança, lavanderia. O Desembargador Nivaldo Balzano apresentou voto vencido no sentido de que não há incidência de ISS no caso em tela. A Riema interpôs os Embargos de Declaração n. ${ }^{\circ}$ 794.623-5/01 $1^{252}$ contra o acórdão da apelação mencionada acima e alegou que o aresto embargado foi omisso a respeito da questão suscitada no item 9 de suas razões de apelação, vale dizer, sobre a impossibilidade de as sociedades em conta de participação serem consideradas contribuintes do ISS. Os Embargos de Declaração foram rejeitados sob o argumento de que a Riema, na qualidade de sócia ostensiva, deve ser tributada e não a sociedade em conta de participação. A Riema interpôs, ainda, os Embargos Infringentes n. ${ }^{0} 794.523-5 / 02^{252}$ contra o acórdão que, por maioria, negou provimento à apelação mencionada acima. Os Embargos Infringentes foram rejeitados.

Ainda sobre este tema, vale destacar que por meio da Apelação Cível n. ${ }^{\circ}$ 852.939-5, rel. Ribeiro de Souza, j. 01.09.2004 $4^{252}$, a Riema interpôs recurso de apelação contra sentença proferida no âmbito de ação declaratória de inexistência de relação jurídica tributária que julgou procedente o pedido da Municipalidade no que se refere à incidência de ISS. O caso dizia respeito ao flat "Edifício Residencial Four Seasons". Os Desembargadores negaram provimento ao recurso e confirmaram a sentença monocrática para o fim de exigir o ISS.

A este respeito, vide também Apelação Cível com Revisão n. ${ }^{\circ}$ 470.251-5/7-00 do Tribunal de Justiça do Estado de São Paulo, em que o Município de São Paulo é apelante e a mesma Riema é apelada. Para fins de esclarecimentos, a Riema é sócia ostensiva de sociedades em conta de participação firmadas com proprietários de unidades autônomas imobiliárias que compõe determinados flats. A discussão da Apelação Cível com Revisão n. ${ }^{\circ} 470.251-5 / 7-00$ diz respeito ao flat denominado "Champs Elisées"252.

A apelação cível se originou de ação declaratória de inexistência de relação jurídico-tributária ajuizada por Riema em face do Município de São Paulo para que seja reconhecido o seu não enquadramento como contribuinte do ISS, nos termos da Lei Municipal n. ${ }^{\circ} 10.423$, de 29 de dezembro de 1987 e da Portaria SF n. ${ }^{\circ}$ 83, de 30 de dezembro de 1995. A ação foi julgada procedente, razão pela qual o Município de São Paulo ajuizou a apelação cível ora analisada. Em sua defesa, a Riema alegou que não exerce atividades de hotelaria e hospedagem, mas sim as atividades de exploração e administração de empreendimentos imobiliários e de bens imóveis. Portanto, a Riema entende que não é contribuinte de ISS, já que sua atividade seria equiparada a locação de bens imóveis e, para reforçar tal fato, esclareceu que os contratos firmados com os locatários das unidades autônomas possuem prazo de vigência indeterminado e natureza residencial e que isso corrobora o fato de que não presta serviços de hotelaria. E, ainda, a Riema alegou que firmou contrato de administração, no sistema de locação em pool, na forma de sociedade em conta de participação e, por essa razão, não pode ser sujeito passivo da obrigação tributária, já que não se enquadra no artigo $8^{\circ}$ do Decreto-Lei n. ${ }^{\circ} 406 / 68^{252}$. E ainda, a Riema mencionou já ser contribuinte do tributo devido à sua atividade de administradora de bens imóveis. O Município de São Paulo, por sua vez, alegou que as receitas derivadas da exploração de flat, assim entendidas as receitas oriundas de serviços de hospedagem e hotelaria, tais como governança, limpeza, arrumação, telefonista, manobrista, mensageiro, 
Outra discussão jurisprudencial comum, no Tribunal de Justiça do Estado de São Paulo - TJSP, no que se refere aos flats diz respeito à cobrança de água e esgoto pela Companhia de Saneamento Básico do Estado de São Paulo - Sabesp. Isso porque a Sabesp argumenta que os flats devem recolher a tarifa de água e esgoto na modalidade de "edifício comercial", enquanto que os sócios ostensivos de sociedades em conta de participação que exploram esta atividade argumentam que o recolhimento deveria ocorrer na modalidade de "edifício residencial".

são passíveis da incidência de ISS. Por essa razão, as atividades exercidas pela Riema se enquadram não somente como locação de bens imóveis, mas também como prestação de serviços. Para esse fim, o Município de São Paulo argumenta que não importa o tipo do contrato firmado com o hóspede e tampouco o tempo de duração do contrato, já que a incidência do tributo deve ser averiguada com base na efetiva natureza dos fatos que a ela deem causa. O Desembargador Relator, Dr. Gonçalves Rostey, negou provimento ao recurso. Para tanto, esclareceu que, no seu entendimento, os serviços que a Municipalidade entende serem passíveis de incidência de ISS na categoria "hotelaria e hospedagem" são, na verdade, prestados pelo condomínio e não pela sócia ostensiva Riema. O Desembargador Marcos Zanuzzi acompanhou o voto do Desembargador Relator.

No entanto, o Desembargador Geraldo Xavier apresentou voto divergente, que foi vencido. Em seu voto, o referido Desembargador julgou procedente o pedido da apelação por entender que os serviços prestados pela Riema em complemento à locação de apartamentos são congêneres aos serviços de hospedagem em hotéis. E, para justificar a sua decisão, o i. Desembargador menciona que as "notas fiscais de locação" emitidas pela Riema discriminam os valores cobrados por dia de permanência no apartamento, bem como as quantias relativas a cada serviço prestado - restaurante, lavanderia, telefone e, ainda, que as datas de entrada e saída dos clientes revelam ocupação de curta duração. Portanto, o Desembargador que apresentou o voto vencido entende que a locação de flats pode abranger a prestação de serviços com as características de hospedagem, já que compreende a oferta de alojamento ou espaço em bem imóvel, a prestação de serviços de limpeza, arrumação, informações, recepção, portaria, serviços de copa, telefone, mensageiros, guarda de bens, dentre outras. Nessa hipótese, caso a sociedade em conta de participação preste o flat preste os referidos serviços, a sócia ostensiva deveria estar sujeita ao recolhimento do ISS na categoria "hospedagem".

Destacamos que o julgado analisado acima constituiu precedente para determinados outros casos, dentre os quais se destaca a Apelação Cível n. ${ }^{\circ}$ 9127386.89.2002.8.26.000 também interposta pela Riema contra sentença que julgou improcedente ação declaratória de inexistência de relação jurídico-tributária. (TJSP Apelação Cível n. ${ }^{\circ}$ 9127386.89.2002.8.26.0000, rel. Osvaldo Palotti Junior, j. 28.04.2011. No mesmo sentido, vide TJSP - Apelação Cível n. ${ }^{\circ}$ 994.09.294809-4, rel. Gonçalves Rostey, j. 11.03.2010. E ainda, Embargos de Declaração n. ${ }^{\circ}$ 994.09.294809-4/50000, rel. Gonçalves Rostey, j. 16.09.2010).

Já em acórdão proferido no âmbito do julgamento da Apelação n. ${ }^{\circ}$ 9111958-28.2006.8.26.0000, os i. Desembargadores entenderam que o recurso deveria ser parcialmente provido, já que entenderam que: (i) até janeiro de 2004 o ISS não era devido pela Riema, já que a Portaria n. ${ }^{\circ}$ 83/95 editada pela Secretaria das Finanças não constituía instrumento legislativo hábil a instituir exigências tributárias; (ii) após janeiro de 2004, com o advento da Lei Complementar n. ${ }^{\circ} 116 / 03$ e da Lei do Município de São Paulo n. ${ }^{\circ}$ 13.701/03, os prestadores de serviços de hospedagem passaram a estar sujeitos ao pagamento do ISS.

Isso porque, a partir de janeiro de 2004, a Lei Complementar n. ${ }^{\circ} 116 / 03$ e a Lei do Município de São Paulo n. ${ }^{\circ}$ 13.701/03 passaram a prever como fato gerador do ISS a prestação dos serviços de hospedagem de qualquer natureza em hotéis, apart-service condominiais, flats, apart-hotéis residência, residenceservice, suíte service, hotelaria marítima, motéis, pensões e congêneres.

Ainda, citamos a Apelação n. ${ }^{\circ}$ 0157425-86.2006.8.26.0000252, em que o Município de São Paulo comparece como apelante e a Riema como apelada. A discussão é em todo semelhante à exposta acima. Na ocasião, os Desembargadores negaram provimento ao recurso, já que entenderam que a discussão diz respeito à incidência do ISS em atividades próprias de flats antes da incidência da Lei Complementar n. ${ }^{\circ}$ 116/03 e da Lei do Município de São Paulo n. ${ }^{\circ}$ 13.701/03. 
A este respeito, há decisões judiciais divergentes. Na Apelação n. ${ }^{\circ}$ 9873460/3, ${ }^{253}$ interposta pelo Condomínio Edifício Brasília Small Town Flat Service II em face da Companhia de Saneamento Básico do Estado de São Paulo - Sabesp -, os Desembargadores entenderam que haviam indicativos no sentido de que o flat estaria caracterizado como edifício comercial e, portanto, negaram provimento ao recurso.

Já na Apelação n. ${ }^{\circ}$ 934866-0/4, ${ }^{254}$ ajuizada pelo Condomínio Edifício Park Avenue Residence Service em face da Companhia de Saneamento Básico do Estado de São Paulo - Sabesp -, os Desembargadores, por votação unânime, entenderam que os flats devem ser enquadrados na categoria mista e, com base nesta classificação é que a Sabesp deve cobrar a tarifa de água e esgoto.

\section{VII.3 A utilização da sociedade em conta de participação no âmbito de projetos florestais}

Conforme já exposto no item III.4.8, é importante destacar a utilização das sociedades em conta de participação constituídas com o objetivo de participar de projetos de reflorestamento.

Neste caso, as sociedades reflorestadoras são sócias ostensivas e os investidores são sócios participantes e o objeto da sociedade em conta de participação é a alienação de parcelas do plantio das árvores após o reflorestamento.

O Decreto-lei n. ${ }^{\circ} 1.134$, de 16 de novembro de 1970, criou duas estruturas societárias para o fim de aplicação em projetos de reflorestamento e obtenção de incentivos fiscais. $\mathrm{O}$ artigo $1^{\circ}$ prevê que a partir do exercício financeiro de 1971, as pessoas jurídicas poderão descontar até $50 \%$ (cinquenta por cento) do valor do imposto de renda devido na declaração de rendimentos, para a aplicação em empreendimentos florestais, cujos projetos tenham sido aprovados pelo Instituto Brasileiro de Desenvolvimento Florestal. $^{255}$

\footnotetext{
${ }^{253}$ TJSP, Apelação Cível n. ${ }^{\circ}$ 987346-0/3, rel. Des. Dirceu Cintra, j. 07.12.2006.

${ }^{254}$ TJSP - Apelação Cível n. ${ }^{\circ}$ 934.866-0/4, rel. Des. Adilson de Araujo, j. 26.08.2008.

${ }^{255}$ Disponível em: <www.planalto.gov.br>. Acesso em: 01 fev. 2013.
} 
$\mathrm{O} \S 1^{\circ}$ do referido artigo prevê, ainda, que as importâncias descontadas poderão ser aplicadas em projetos de desenvolvimento florestal opcionalmente, sob a forma de: (i) Participação societária acionária; (ii) Participação societária não acionária em projetos de pluri-participação.

Posteriormente, o Decreto n. ${ }^{\circ}$ 79.046, de 27 de dezembro de 1976, previu, em seu artigo 27, que as sociedades em conta de participação, regidas pelos então vigentes artigos 325 e 328 do Código Comercial Brasileiro, ficam equiparadas as sociedades não acionárias de pluriparticipação. ${ }^{256}$

\section{VII.4 A utilização da sociedade em conta de participação como espécie de joint venture}

O conceito de joint venture abrange "todas as formas de associação de empresas com o objetivo de realização de atividades econômicas e com escopo de lucro". 257

A joint venture não é uma criação dos legisladores nacionais, pois nasce do interesse prático, sendo uma mescla da criação civilista e do interesse prático e consuetudinário da common law. ${ }^{258}$

Há duas modalidades de joint venture: as corporate joint ventures e as non corporate joint ventures. A principal característica da primeira modalidade é a constituição de uma pessoa jurídica que formaliza a associação de duas ou mais pessoas para fim comum. Já na segunda modalidade, não há a constituição de uma nova pessoa jurídica.

\footnotetext{
${ }^{256}$ Disponível em: <www.planalto.gov.br>. Acesso em: 01 fev. 2013. O referido Decreto previu, ainda, em seu artigo 27, em seus parágrafos que: "As pessoas jurídicas quotistas do Fundo de Investimento Setoriais - FISET - Florestamento e Reflorestamento que converterem suas quotas em títulos de capital de Sociedade em Conta de Participação ficam equiparadas aos sócios participantes destas." E, ainda, que: "A sócia gerente ou administrativa da Sociedade em Conta de Participação é a responsável pelo empreendimento florestal e sua representante legal perante o IBDF."

"A responsabilidade da sócia gerente, beneficiária do projeto, não excluirá a responsabilidade da executora que, por culpa, deixar de satisfazer os serviços contratados".

${ }^{257}$ Conforme SALOMÃO FILHO, Calixto. Direito concorrencial: as estruturas. São Paulo: Malheiros, 1998., p. 321.

${ }^{258}$ Conforme BASSO, Maristela. Joint venture: manual prático. Porto Alegre: Livraria do Advogado, 1994. p. 35 .
} 
Assim, há autores ${ }^{259}$ que defendem que as sociedades em conta de participação são subespécie do gênero non corporate joint ventures.

No entanto, entendemos que há determinadas diferenças entre os referidos institutos.

Com efeito, as non corporate joint ventures não lidam com o conceito de sócios participantes. Além disto, nas non corporate joint ventures as partes podem livremente convencionar quem se obrigará perante terceiros, enquanto que nas sociedades em conta de participação esta prerrogativa está restrita aos sócios ostensivos.

Ademais, as sociedades em conta de participação podem ser constituídas por prazo determinado ou indeterminado, enquanto que as joint ventures devem ter prazo determinado de duração.

Gustavo Oliva Galizzi, ${ }^{260}$ ao analisar a questão, concluiu que a sociedade em conta de participação pode ser classificada como unincorporated joint venture (latu sensu), pois não dá origem a uma nova pessoa jurídica, mas com características sui generis, já que as seguintes características as distinguem das joint ventures: (i) existência de um sócio participante, (ii) a responsabilidade do sócio ostensivo perante terceiros, e (iii) a transferência da propriedade dos investimentos dos demais sócios ao sócio ostensivo, que os administra no interesse comum.

Assim, enquadrada a sociedade em conta de participação como subespécie de joint venture, a sua utilização como instrumento de parcerias internacionais ou nacionais é de grande valia.

${ }^{259}$ COSTA, José Maria da. A sociedade em conta de participação no direito de empresa do Código Civil de 2002. (Dissertação de Mestrado). São Paulo: Pontifícia Universidade Católica, Faculdade de Direito, 2006. p. 135. Neste sentido, vide também BASSO, Maristela. Op. cit., p. 44.

${ }^{260}$ GALIZZI, Gustavo Oliva. Op. cit., p. 206-218. 


\section{VII.5 A sociedade em conta de participação na jurisprudência brasileira}

Tendo em vista que o objetivo deste Capítulo é de compilar uma análise empírica das sociedades em conta de participação no direito brasileiro, mister realizar uma análise jurisprudencial a respeito do tema.

Com isto, será possível obter informações a respeito das mais variadas formas de utilização das sociedades em conta de participação, além de levantar dados a respeito dos casos julgados sobre o tema, especialmente no que se refere aos assuntos mais controvertidos.

\section{VII.5.1 Objetivos}

Este subitem tem por objetivo apontar uma metodologia para sistematizar parte da jurisprudência referente às sociedades em conta de participação.

Ademais, este subitem tem por objetivo compilar informações sobre determinadas decisões em matéria de sociedade em conta de participação no Tribunal de Justiça do Estado do Rio de Janeiro, no Tribunal de Justiça do Estado de São Paulo, no Superior Tribunal de Justiça e no Supremo Tribunal Federal.

Para atingir tais objetivos, o trabalho dividiu-se em duas etapas.

Na primeira etapa, houve a elaboração de banco de dados, no qual foram organizadas as decisões judiciais sobre sociedade em conta de participação dos tribunais indicados e foram elencadas as informações correlatas, - tais como indicação do tribunal, data do julgamento, tipo e número do recurso, nome do relator, nome das partes, descrição da causa e conteúdo da decisão. O banco de dados elaborado constitui o Anexo II a este trabalho.

$\mathrm{Na}$ segunda etapa, analisamos os dados levantados e organizados, com o objetivo de traçar informações sobre o funcionamento do Poder Judiciário no que se referem as matérias que envolvem a sociedade em conta de participação, tais como 
quem são as partes litigantes, quais matérias são levadas para apreciação do Poder Judiciário, dentre outras.

Este subitem não tem a pretensão de realizar um compêndio de jurisprudência com o fim de ser utilizado por advogados e juízes em suas tarefas cotidianas, mas fornecer um estudo para melhor conhecimento das matérias litigiosas que envolvem sociedades em conta de participação.

\section{VII.5.2 Metodologia para a formação do banco de dados}

Inicialmente, realizamos busca nos websites do Tribunal de Justiça do Estado do Rio de Janeiro, do Supremo Tribunal Federal e do Superior Tribunal de Justiça. Para tanto, utilizamos critério de busca genérico, com levantamento de todas as decisões cuja ementa continha as palavras "sociedade em conta de participação".

O levantamento de informações no website do Tribunal de Justiça do Estado do Rio de Janeiro - TJRJ - ocorreu durante o mês de abril de 2013. Os dados levantados referem-se ao período de 1975 a 2013. A pesquisa realizada culminou na indicação de 170 (cento e setenta) acórdãos. Dentre estes, foram selecionados 77 (setenta e sete) acórdãos que efetivamente referiam-se a sociedades em conta de participação e que eram relevantes para os fins deste estudo.

Já o levantamento de informações no website do Tribunal de Justiça do Estado de São Paulo - TJSP - ocorreu durante o mês de maio de 2013.

A pesquisa realizada no Tribunal de Justiça do Estado de São Paulo - TJSP, sem limitação temporal, a partir da indicação das palavras genéricas "sociedade em conta de participação" resultou em 82.369 (oitenta e dois mil, trezentos e sessenta e nove) acórdãos.

Tendo em vista que o número de acórdãos resultados da busca das palavras "sociedade em conta de participação" foi expressivo, a palavra "sócio ostensivo" foi 
agregada à busca e resultou na indicação de 189 (cento e oitenta e nove acórdãos), sem limitação temporal.

A partir do resultado mencionado acima, analisamos as decisões julgadas nos anos de 2011, 2012 e 2013.

Ademais, também foram analisadas decisões do Tribunal de Justiça do Estado de São Paulo - TJSP levantadas a partir de sua indicação em textos doutrinários ou em determinadas outras decisões jurisprudenciais examinadas ao longo do desenvolvimento do trabalho.

Com isto, o número de decisões proferidas por Desembargadores do Tribunal de Justiça do Estado de São Paulo e que foram analisadas no âmbito do trabalho consubstanciado neste subitem totaliza 53 (cinquenta e três) acórdãos.

A busca no website do Superior Tribunal de Justiça - STJ - foi realizada em março de 2012 e confirmada em maio de 2013. Também foi utilizado critério de busca genérico, com levantamento de todas as decisões cuja ementa indicou as palavras "sociedade em conta de participação", sem limitação temporal.

A busca no website do Superior Tribunal de Justiça - STJ - resultou em 62 resultados. Os referidos acórdãos foram analisados e somente 8 (oito) acórdãos efetivamente referiam-se a discussões relevantes a respeito de sociedade em conta de participação.

Também foram realizadas buscas no website do Supremo Tribunal Federal STF - durante o mês de março de 2012. As referidas buscas foram confirmadas em maio de 2013.

A pesquisa teve como premissa o levantamento de todas as informações, sem limite temporal, que contivessem as palavras "sociedade em conta de participação" nas respectivas ementas. 
Os resultados indicaram 22 (vinte e duas) decisões das quais, após a análise de seu conteúdo, foram selecionadas 14 (quatorze).

A partir dos resultados das buscas, que seguiram os critérios acima apontados, foi elaborado o relatório anexo com informações a respeito dos acórdãos analisados.

\section{VII.5.3 Resultados}

Após a elaboração descritiva dos dados, é importante analisar os resultados obtidos.

Inicialmente, este subitem analisará os resultados obtidos a partir dos dados do Tribunal de Justiça do Estado de São Paulo - TJSP - e do Tribunal de Justiça do Estado do Rio de Janeiro - TJRJ.

Ato contínuo este trabalho passará à análise dos resultados obtidos a partir dos julgados do Superior Tribunal de Justiça - STJ. Por fim, este trabalho abordará os acórdãos do Supremo Tribunal Federal - STF.

\section{VII.5.3.1 TJSP e TJRJ}

\section{A. Divisão dos recursos}

Tabela 1. Divisão dos recursos

\begin{tabular}{||l||c|c||}
\hline \multicolumn{1}{|c|}{ Tipo de Recurso } & Frequência & Percentual \\
\hline \hline Agravo de Instrumento & 14 & $10,76 \%$ \\
\hline Apelação Cível & 99 & $76,16 \%$ \\
\hline \hline Embargos de Declaração & 7 & $5,38 \%$ \\
\hline Outros & 10 & $7,70 \%$ \\
\hline \hline \multicolumn{1}{|c|}{ Total } & $\mathbf{1 3 0}$ & $\mathbf{1 0 0 , 0 0 \%}$ \\
\hline
\end{tabular}




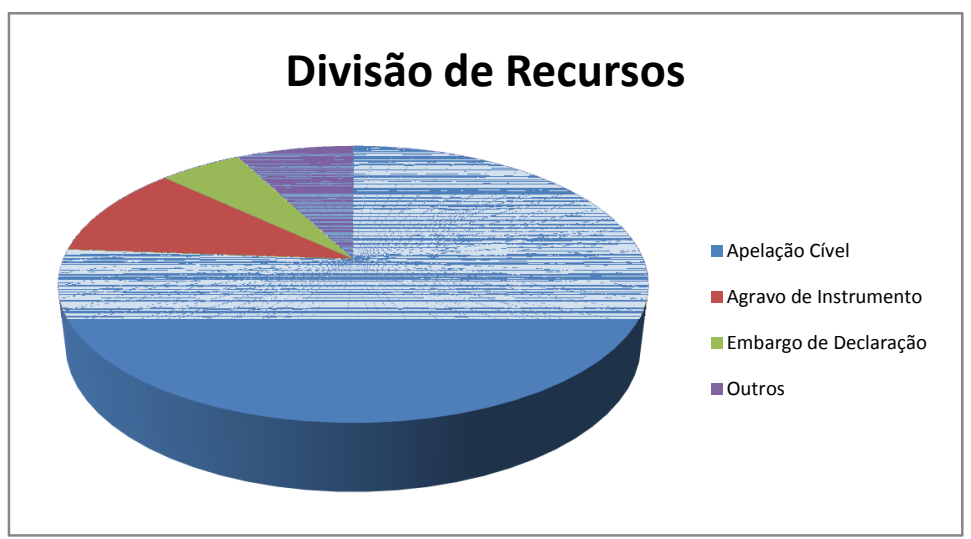

\section{B. Partes}

As partes foram classificadas tendo em vista as posições em relação ao recurso e não em relação à ação interposta em primeira instância. Assim, por exemplo, o apelante foi indicado como autor e o apelado foi indicado como réu. Para os fins de análise deste item, nos casos em que havia mais de um autor e/ou réu e que, dentre os autores e/ou réus havia pessoas físicas e jurídicas, foram considerados os autores e os réus, em questão, como pessoas jurídicas.

Tabela 2. Autores dos casos

\begin{tabular}{|c|c|c|}
\hline \multicolumn{1}{|c|}{ Autor } & Frequência & Percentual \\
\hline \hline Pessoa jurídica & 79 & $60,77 \%$ \\
& & \\
\hline \hline Pessoa física & 43 & $33,07 \%$ \\
\hline \hline Ministério Público & 1 & $0,77 \%$ \\
\hline \hline Outros Total & 7 & $5,39 \%$ \\
\hline \hline \multicolumn{2}{|c|}{ Tot } & $100,00 \%$ \\
\hline
\end{tabular}




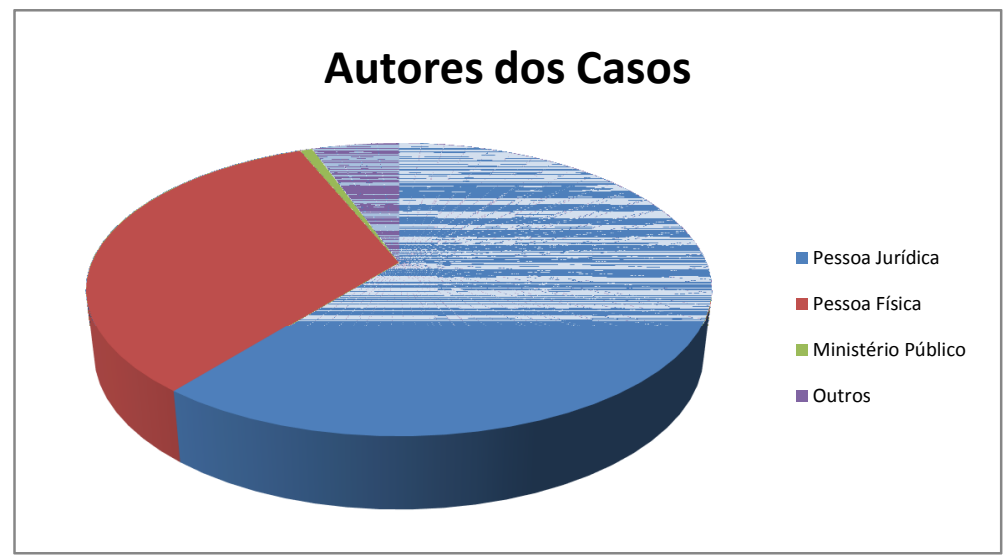

Tabela 3. Réus dos casos

\begin{tabular}{|l|c|c|}
\hline \multicolumn{1}{|c|}{ Réu } & Frequência & Percentual \\
\hline \hline Pessoa jurídica & 58 & $44,63 \%$ \\
\hline \hline Pessoa física & 59 & $45,38 \%$ \\
\hline \hline Ministério Público & 1 & $0,77 \%$ \\
\hline \hline Outros & 12 & $9,22 \%$ \\
\hline \hline \multicolumn{1}{|c|}{ Total } & $\mathbf{1 3 0}$ & $\mathbf{1 0 0 , 0 0 \%}$ \\
\hline
\end{tabular}

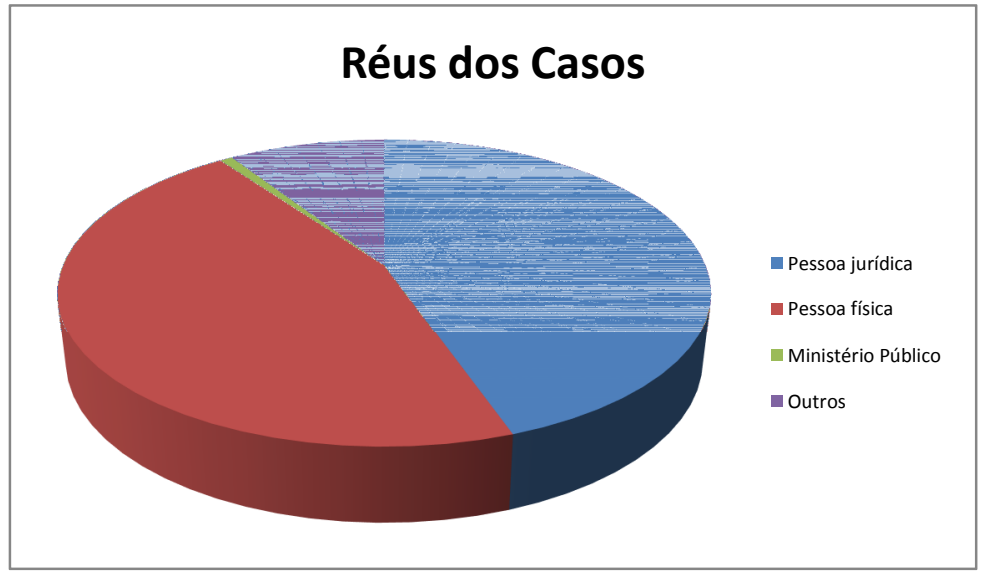

\section{Matéria litigiosa}

Tabela 4. Matéria litigiosa

\begin{tabular}{|l|c|c||}
\hline \multicolumn{1}{|c|}{ Matéria (direito) } & Frequência & Percentual \\
\hline Patrimônio especial da SCP & 1 & $0,77 \%$ \\
\hline \hline Discussões criminais & 2 & $1,53 \%$ \\
\hline Discussões tributárias & 11 & $8,47 \%$ \\
\hline
\end{tabular}




\begin{tabular}{|c|c|c|}
\hline Licença de funcionamento & 1 & $0,77 \%$ \\
\hline Responsabilidade do sócio participante por prejuízos & 9 & $6,93 \%$ \\
\hline $\begin{array}{l}\text { Cessão de participação societária sem anuência do } \\
\text { sócio participante }\end{array}$ & 2 & $1,53 \%$ \\
\hline Administração & 1 & $0,77 \%$ \\
\hline $\begin{array}{l}\text { Pedido de dissolução, rescisão, anulação, nulidade de } \\
\text { SCP e consequente danos materiais e/ou morais }\end{array}$ & 68 & $52,31 \%$ \\
\hline $\begin{array}{l}\text { Cobrança de valores devidos - créditos, haveres ou } \\
\text { resultados }\end{array}$ & 14 & $10,78 \%$ \\
\hline $\begin{array}{l}\text { Caracterização de SCP, Natureza da SCP e/ou } \\
\text { competência para julgamento de matérias relacionadas } \\
\text { a SCP - vara cível (contrato) ou empresarial } \\
\text { (sociedade) }\end{array}$ & 12 & $9,23 \%$ \\
\hline Relação entre sócios & 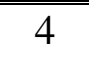 & $3,07 \%$ \\
\hline Exibição de documentos ou prestação de contas & 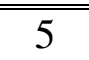 & $3,84 \%$ \\
\hline Total & 130 & $100,00 \%$ \\
\hline
\end{tabular}

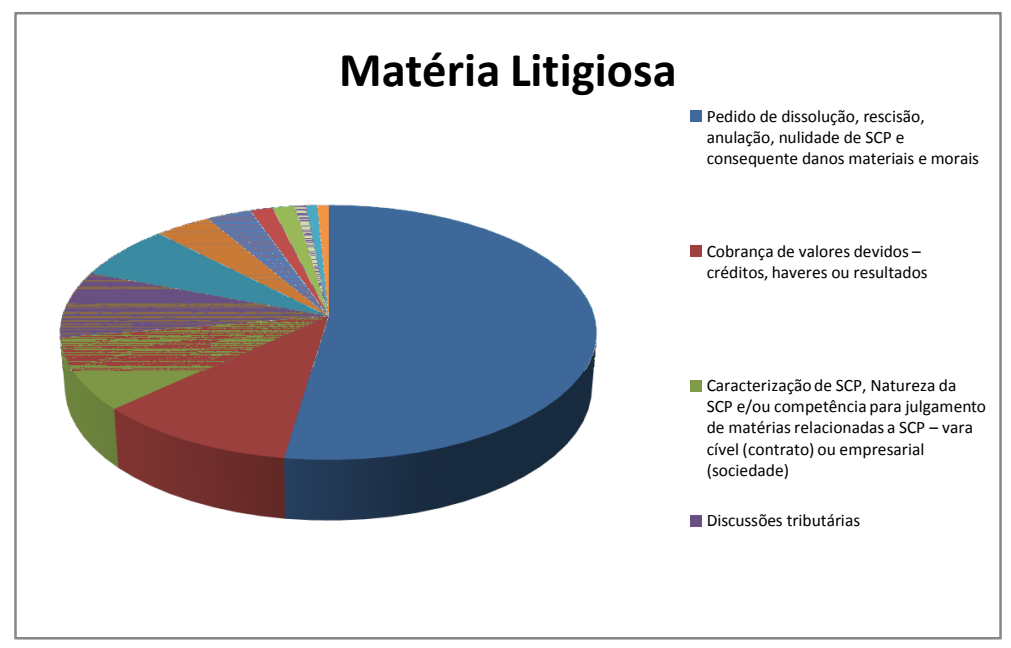

D. Atividades desenvolvidas pelas SCPs envolvidas nos litígios:

Tabela 5. Atividades das SCPs

\begin{tabular}{|l||c||c||}
\hline \multicolumn{1}{|c|}{ Matérias (fatos) } & Frequência & Percentual \\
\hline \hline Investimentos imobiliários & 92 & $70,77 \%$ \\
\hline \hline Investimentos em reflorestamento & 4 & $3,07 \%$ \\
\hline
\end{tabular}




\begin{tabular}{|l||c||c||}
\hline $\begin{array}{l}\text { Investimentos em sociedades } \\
\text { (comércio de roupas, blindagem } \\
\text { de veículos, venda de veículos, } \\
\text { casa noturna, restaurante) }\end{array}$ & 15 & $11,54 \%$ \\
\hline \hline Aquisição de veículo & & \\
\hline \hline Outros & 1 & $0,77 \%$ \\
\hline \hline Total & 18 & $13,85 \%$ \\
\hline
\end{tabular}

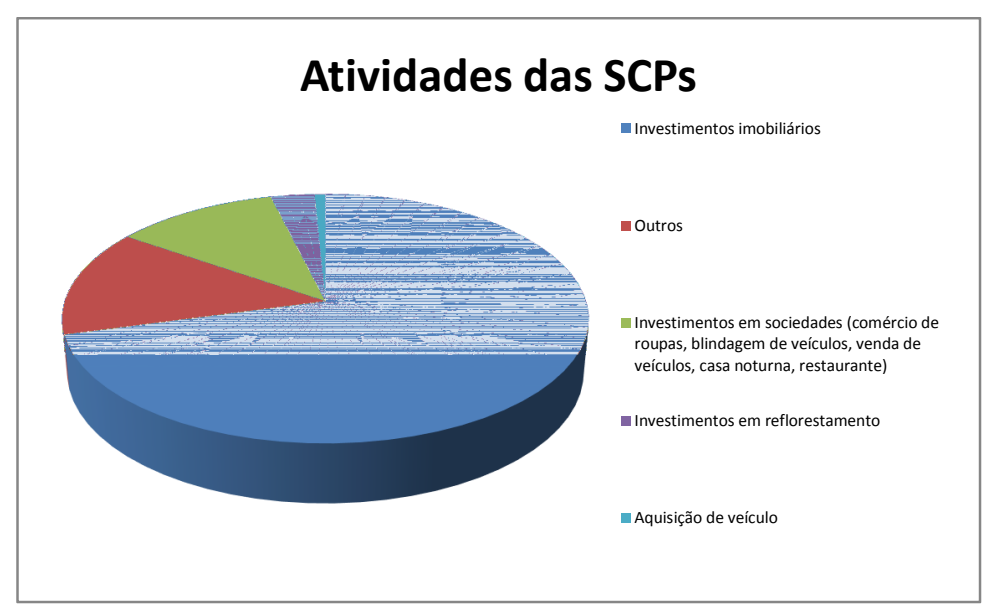

\section{E. Decisão}

Tabela 6. Parte e resultado do recurso ${ }^{261}$

\begin{tabular}{|l||c||c|}
\hline \multicolumn{1}{|c|}{ Decisão } & Frequência & Percentual \\
\hline \hline Em favor do réu & 85 & $65,38 \%$ \\
\hline \hline Em favor do autor & 36 & $27,70 \%$ \\
\hline \hline Provimento parcial e/ou & 9 & $6,92 \%$ \\
decisão cujo resultado não & & \\
foi favorável e/ou & & \\
desfavorável ao réu & & $\mathbf{1 0 0 , 0 0 \%}$ \\
\hline \hline \multicolumn{1}{|c|}{ Total } & $\mathbf{1 3 0}$ & \\
\hline \multicolumn{1}{|c|}{} & & \\
\hline
\end{tabular}

${ }^{261}$ Ressalta-se que não é decisão do caso, mas sim do recurso, pois muitos casos ainda estão pendentes de decisão nas instâncias superiores. 


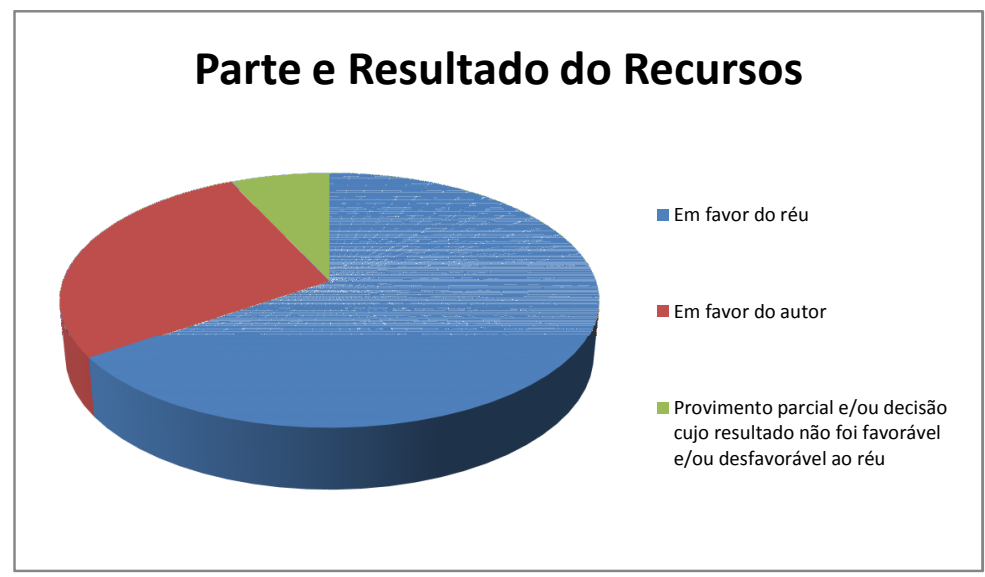

\section{VII.5.3.2 STJ}

A. Divisão dos recursos

Tabela 7. Divisão dos recursos

\begin{tabular}{|c|c|c|}
\hline \multicolumn{1}{|c|}{ Tipo de Recurso } & Frequência & Percentual \\
\hline \hline Conflito de Competência & 1 & $12,50 \%$ \\
\hline \hline Recurso Especial & 7 & $87,50 \%$ \\
\hline \hline Total & $\mathbf{8}$ & $\mathbf{1 0 0 , 0 0 \%}$ \\
\hline
\end{tabular}

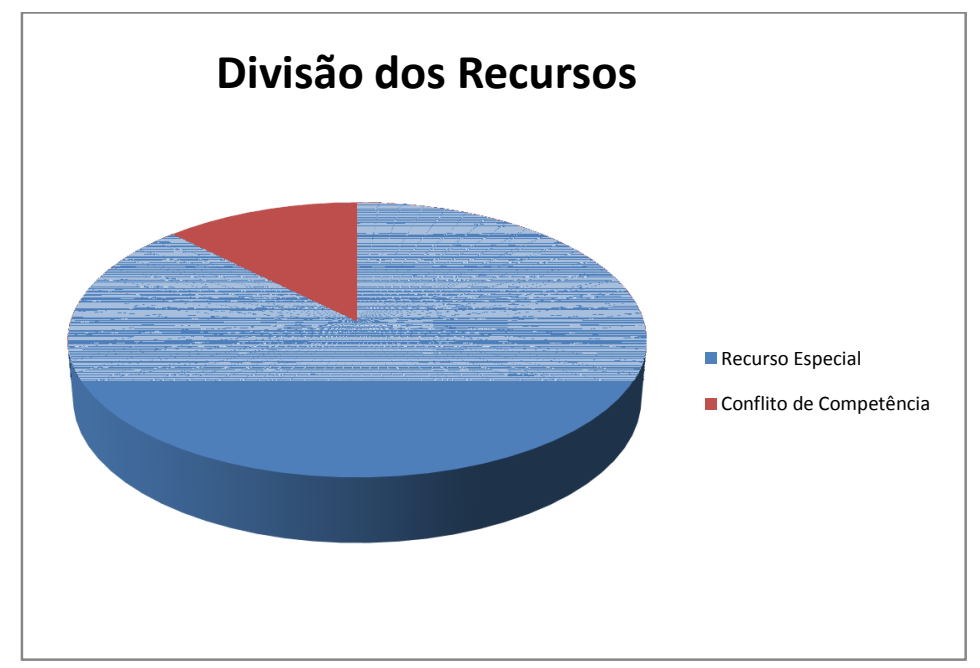




\section{B. $\quad$ Partes}

As partes foram classificadas tendo em vista as posições em relação ao recurso e não em relação à ação interposta em primeira instância. Assim, por exemplo, o recorrente foi indicado como autor e o recorrido foi indicado como réu.

Tabela 8. Autores dos casos

\begin{tabular}{|l|c|c|}
\hline \multicolumn{1}{|c|}{ Autor } & Frequência & Percentual \\
\hline \hline Pessoa jurídica & 4 & $50,00 \%$ \\
\hline \hline Pessoa física & 3 & $37,50 \%$ \\
\hline Ministério Público & 0 & 0 \\
\hline \hline Outros Total & 1 & $12,50 \%$ \\
\hline \hline \multicolumn{2}{|c|}{ To } & $\mathbf{1 0 0 , 0 0 \%}$ \\
\hline
\end{tabular}

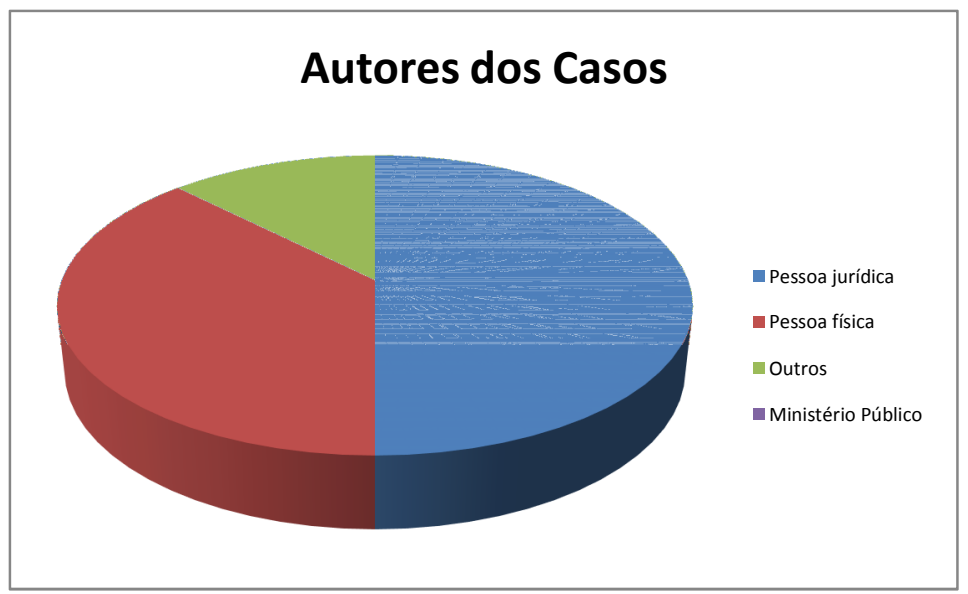

Tabela 9. Réus dos casos

\begin{tabular}{|l|c|c|}
\hline \multicolumn{1}{|c|}{ Réu } & Frequência & Percentual \\
\hline \hline Pessoa jurídica & 5 & $62,50 \%$ \\
\hline \hline Pessoa física & 1 & $12,50 \%$ \\
\hline \hline Ministério Público & 0 & 0 \\
\hline \hline Outros & 2 & $25,00 \%$ \\
\hline \hline \multicolumn{1}{|c|}{ Total } & $\mathbf{8}$ & $\mathbf{1 0 0 , 0 0 \%}$ \\
\hline
\end{tabular}




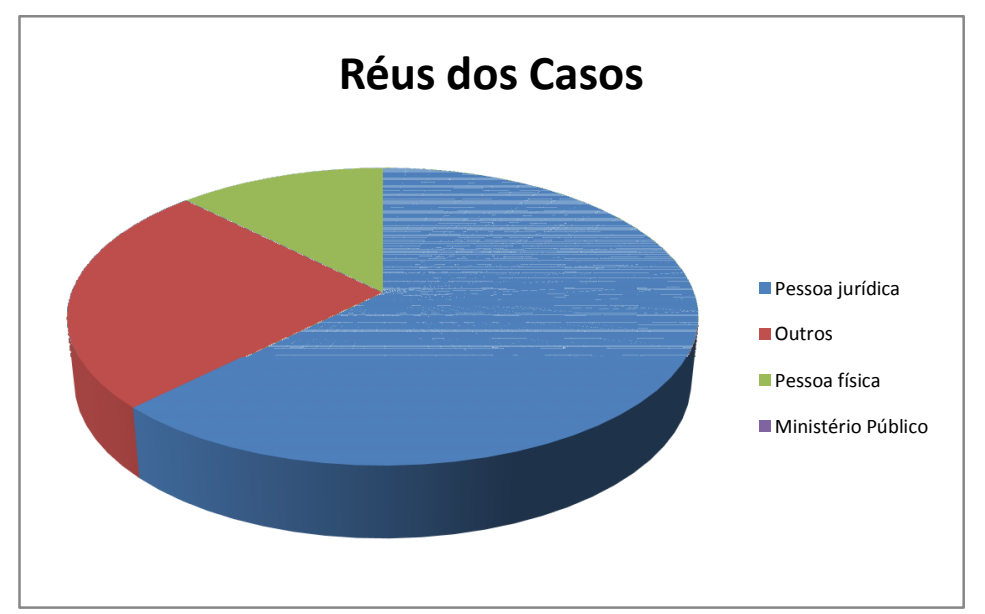

\section{Matéria litigiosa.}

Tabela 10. Matérias litigiosas.

\begin{tabular}{|l|c||c||}
\hline \multicolumn{1}{|c|}{ Matéria } & Frequência & Percentual \\
\hline \hline Relação entre sócios & 3 & $37,50 \%$ \\
\hline Responsabilidade da sócia ostensiva por culpa ou dolo & 1 & $12,50 \%$ \\
\hline \hline Dissolução de SCP e participação nos resultados & 2 & $25,00 \%$ \\
\hline \hline Questões tributárias & 1 & $12,50 \%$ \\
\hline $\begin{array}{l}\text { Competência para julgar matéria criminal de captação } \\
\text { de recursos de terceiros via SCP sem a autorização do } \\
\text { Bacen }\end{array}$ & 1 & $12,50 \%$ \\
\hline \hline Total & $\mathbf{8}$ & $\mathbf{1 0 0 , 0 0 \%}$ \\
\hline
\end{tabular}

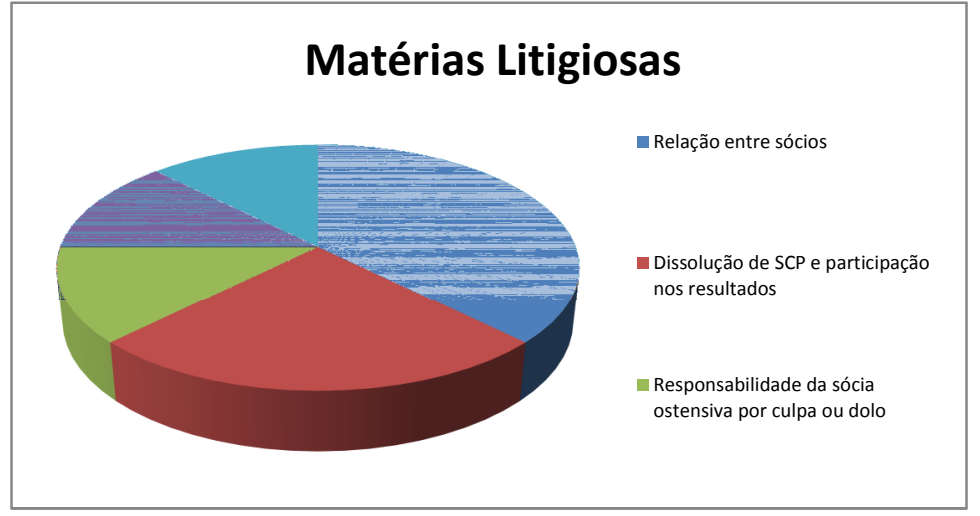


D. Tabela 11. Atividades desenvolvidas pelas SCPs envolvidas nos litígios

\begin{tabular}{|l|c|c|}
\hline \multicolumn{1}{|c|}{ Matéria } & Frequência & Percentual \\
\hline \hline Produção de espetáculo musical & 1 & $12,50 \%$ \\
\hline Reflorestamento & 1 & $12,50 \%$ \\
\hline \hline Atividades imobiliárias & 5 & $62,50 \%$ \\
\hline \hline Projeto de divulgação de aventuras de viagem & 1 & $12,50 \%$ \\
\hline \hline \multicolumn{1}{|c|}{ Total } & $\mathbf{8}$ & $\mathbf{1 0 0 , 0 0 \%}$ \\
\hline
\end{tabular}

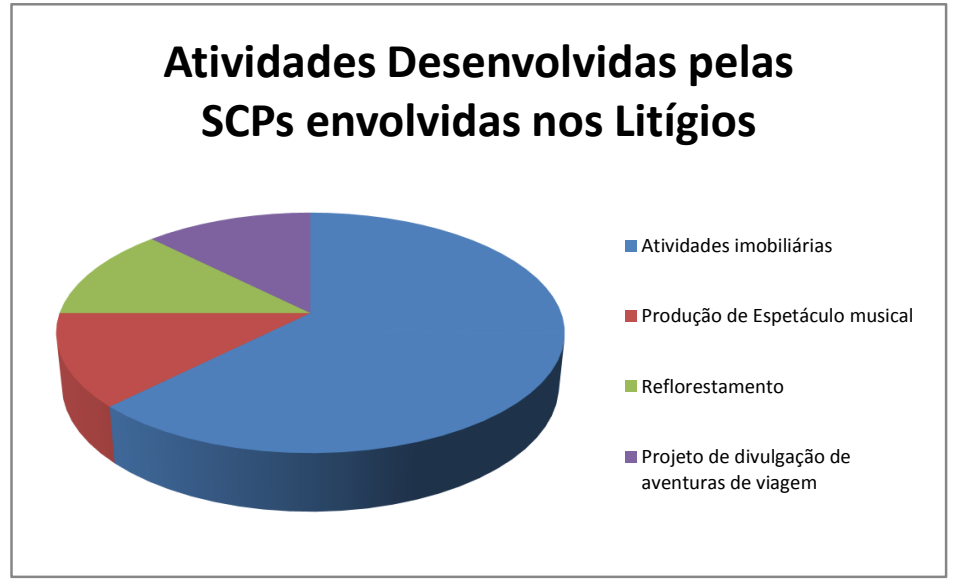

\section{E. Decisão}

Tabela 12. Parte e resultado do recurso ${ }^{262}$

\begin{tabular}{|l|c|c||}
\hline \multicolumn{1}{|c|}{ Decisão } & Frequência & Percentual \\
\hline \hline Em favor do réu & 3 & $37,50 \%$ \\
\hline \hline Em favor do autor & 2 & $25,00 \%$ \\
\hline $\begin{array}{l}\text { Provimento parcial e/ou decisão cujo resultado não } \\
\text { foi favorável e/ou desfavorável ao réu }\end{array}$ & 3 & $37,50 \%$ \\
\hline \hline \multicolumn{1}{|c|}{ Total } & $\mathbf{8}$ & $\mathbf{1 0 0 , 0 0 \%}$ \\
\hline
\end{tabular}

\footnotetext{
${ }^{262}$ Ressalta-se que não é decisão do caso, mas sim do recurso, pois muitos casos ainda estão pendentes de decisão nas instâncias superiores.
} 


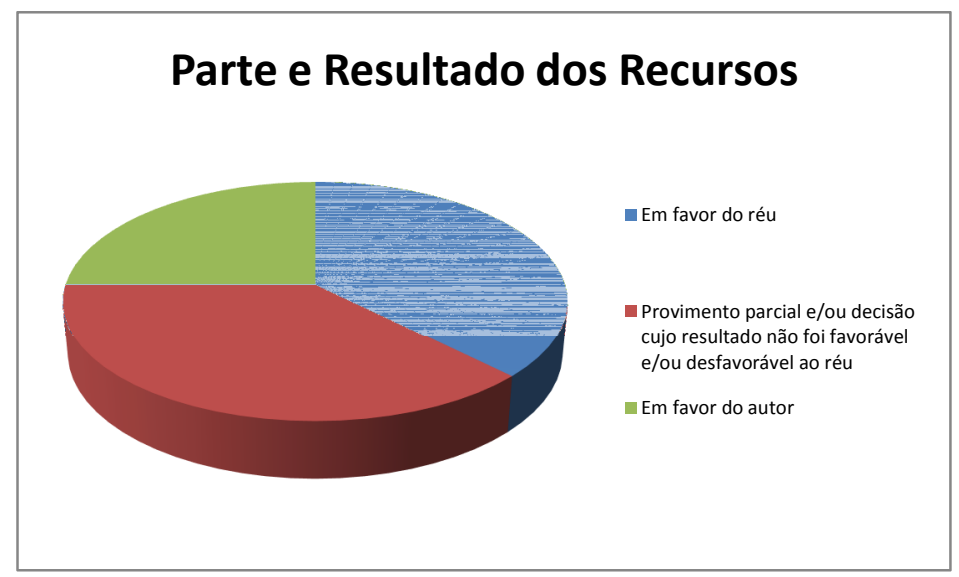

\section{VII.5.3.3 STF}

A. Divisão dos recursos

Tabela 13. Divisão dos recursos

\begin{tabular}{||l|c|c||}
\hline \multicolumn{1}{|c|}{ Tipo de Recurso } & Frequência & Percentual \\
\hline \hline Recurso Extraordinário & 8 & $57,14 \%$ \\
\hline \hline Agravo de Instrumento & 5 & $35,72 \%$ \\
\hline \hline Embargos Declaratórios no Agravo de Instrumento & 1 & $7,14 \%$ \\
\hline \multicolumn{1}{|c|}{ Total } & $\mathbf{1 4}$ & $\mathbf{1 0 0 , 0 0 \%}$ \\
\hline
\end{tabular}

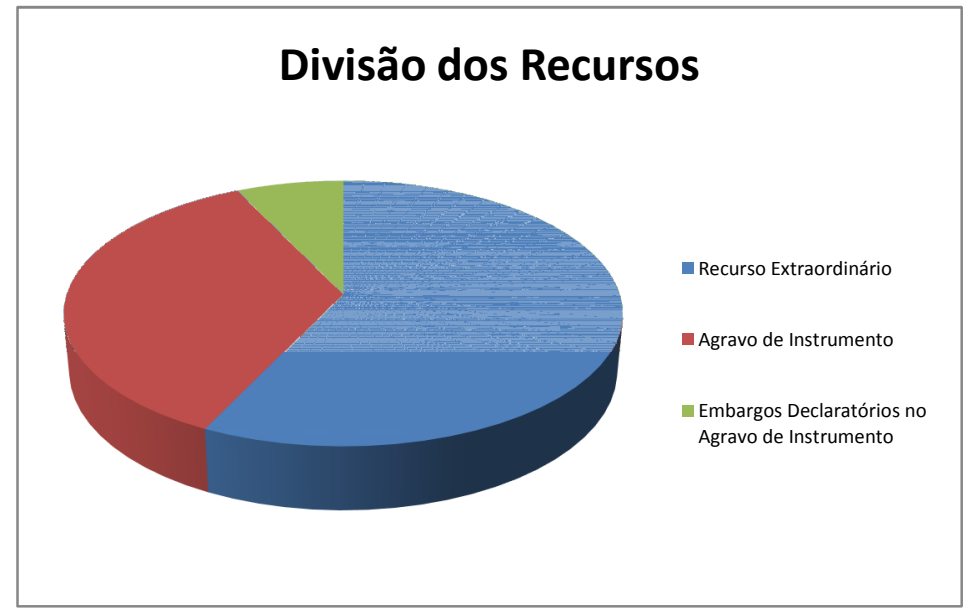




\section{B. $\quad$ Partes}

As partes foram classificadas tendo em vista as posições em relação ao recurso e não em relação à ação interposta em primeira instância. Assim, o recorrente foi indicado como autor e o recorrido foi indicado como réu.

Tabela 14. Autores dos casos

\begin{tabular}{|l|c|c|}
\hline \multicolumn{1}{|c||}{ Autor } & Frequência & Percentual \\
\hline \hline Pessoa jurídica & 5 & $35,65 \%$ \\
\hline \hline Pessoa física & 9 & $64,35 \%$ \\
\hline \hline Ministério Público & 0 & - \\
\hline \hline Outros & 0 & - \\
\hline \hline \multicolumn{1}{|c|}{ Total } & $\mathbf{1 4}$ & $\mathbf{1 0 0 , 0 0 \%}$ \\
\hline
\end{tabular}

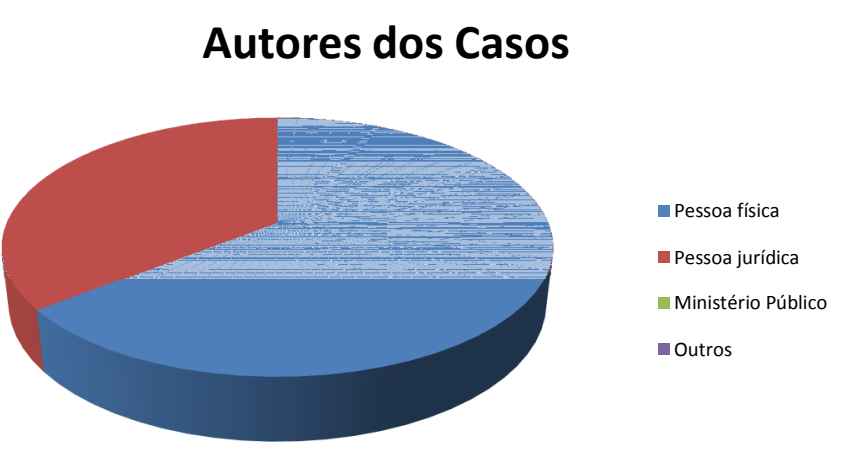

Tabela 15. Réus dos casos

\begin{tabular}{|l|c|c|}
\hline \multicolumn{1}{|c|}{ Réu } & Frequência & Percentual \\
\hline \hline Pessoa jurídica & 4 & $28,57 \%$ \\
\hline Pessoa física & 10 & $71,43 \%$ \\
\hline \hline Ministério Público & 0 & \\
\hline \hline Outros & 0 & $\mathbf{1 0 0 , 0 0 \%}$ \\
\hline \hline \multicolumn{1}{|c|}{ Total } & $\mathbf{1 4}$ & \\
\hline
\end{tabular}




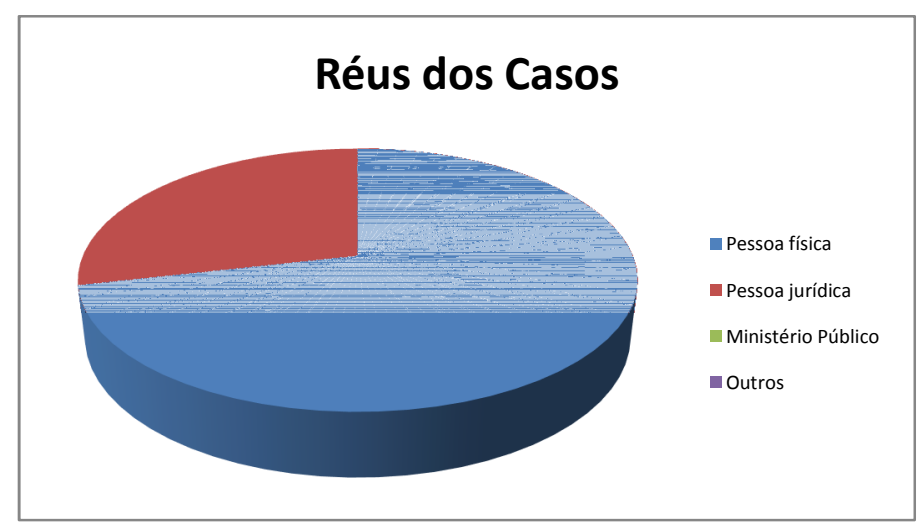

C. Matéria litigiosa

Tabela 16. Matéria litigiosa

\begin{tabular}{|l|c|c|}
\hline \multicolumn{1}{|c|}{ Matéria } & Frequência & Percentual \\
\hline \hline Dissolução de SCP/Prestação de contas & 3 & 21,42 \\
\hline \hline Meios de prova de existência de SCP & 4 & 28,58 \\
\hline Licitude do objeto social & 1 & 7,14 \\
\hline \hline Caracterização de SCP & 5 & 35,72 \\
\hline \hline Outras & 1 & 7,14 \\
\hline \hline \multicolumn{1}{|c|}{ Total } & $\mathbf{1 4}$ & $\mathbf{1 0 0 , 0 0 \%}$ \\
\hline \hline
\end{tabular}

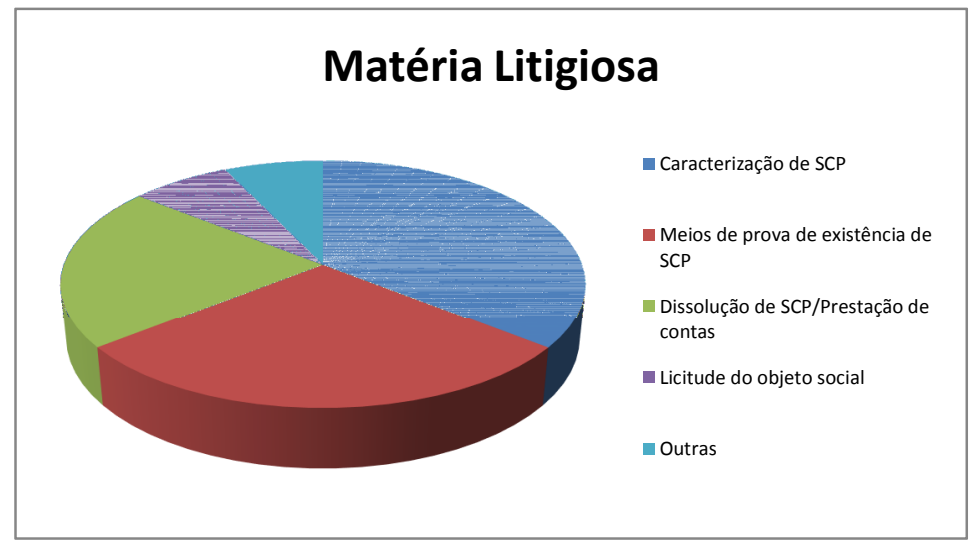


Tabela 17. Atividades desenvolvidas pelas SCPs envolvidas nos litígios

\begin{tabular}{|l|c|c|}
\hline \multicolumn{1}{|c|}{ Matéria } & Frequência & Percentual \\
\hline \hline Venda de brilhante & 1 & $7,16 \%$ \\
\hline \hline Atividades imobiliárias & 3 & $21,42 \%$ \\
\hline \hline Outras & 10 & $71,42 \%$ \\
\hline Total & $\mathbf{1 4}$ & $\mathbf{1 0 0 , 0 0 \%}$ \\
\hline
\end{tabular}

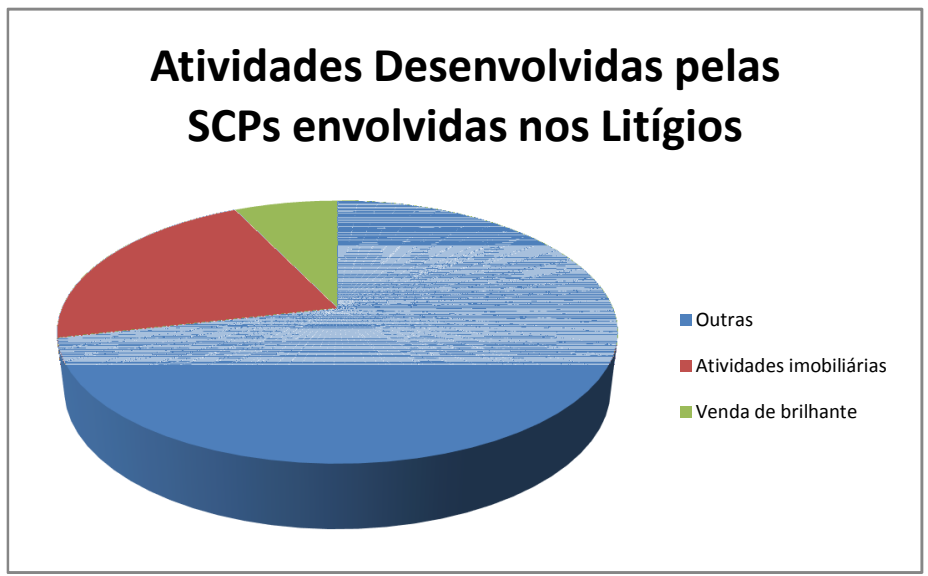

D.

Decisão

Tabela 18. Parte e resultado do recurso ${ }^{263}$

\begin{tabular}{|c||c||c|}
\hline \multicolumn{1}{|c|}{ Decisão } & Frequência & Percentual \\
\hline \hline Em favor do réu & 11 & $78,57 \%$ \\
\hline Em favor do autor & 3 & $21,43 \%$ \\
\hline \hline Total & 14 & $100,00 \%$ \\
\hline
\end{tabular}

${ }^{263}$ Ressalta-se que não é decisão do caso, mas sim do recurso, pois muitos casos ainda estão pendentes de decisão nas instâncias superiores. 


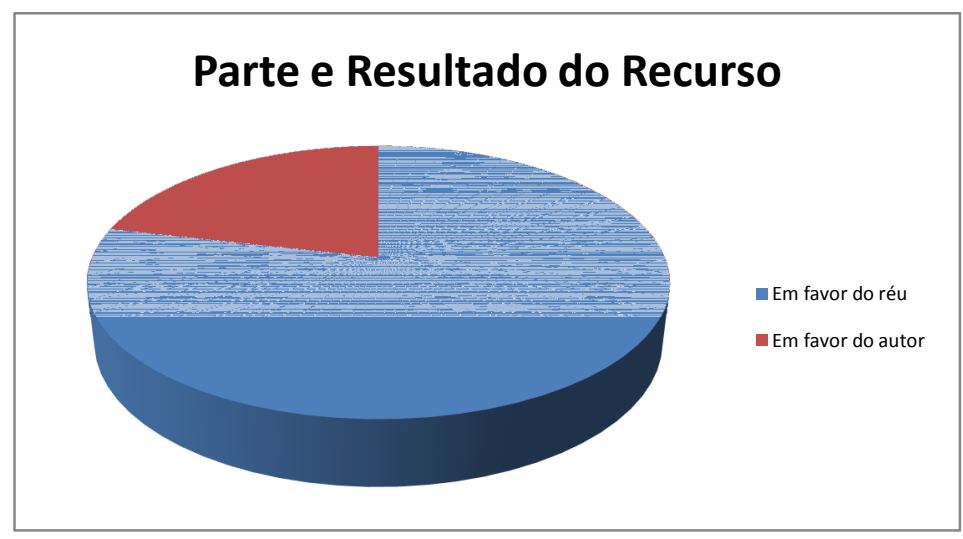

\section{VII.5.3.4 Utilização da sociedade em conta de participação como forma de evitar a aplicação de normas específicas e mais rígidas}

Além das conclusões refletidas nos quadros acima, é importante destacar que a análise jurisprudencial resultou em uma constatação surpreendente a respeito da utilização das sociedades em conta de participação como forma de instrumentalizar operações - de certa forma - fraudulentas, já que estruturadas para evitar a incidência de leis específicas e mais rígidas.

As sociedades em conta de participação, nestes casos, podem ser consideradas nulas em decorrência do quanto previsto no artigo 167 do Código Civil de 2002.

Do total de 152 (cento e cinquenta e dois) acórdãos analisados, 52 (cinquenta e dois) tem por objeto a discussão a respeito da utilização de sociedade em conta de participação para estruturar relações jurídicas típicas e que deveriam ser construídas sob outro arcabouço jurídico, com normas mais rígidas. E, ainda, 31 (trinta e um) acórdãos envolvem uma mesma pessoa jurídica acusada de utilizar sociedade em conta de participação para os fins referidos acima.

O caso mais comum consiste na divulgação pública - por meio de cartazes e publicidade em jornais, rádio e revistas - sobre a concessão de financiamento para aquisição de casa própria. As condições do empréstimo são facilitadas, sem consulta ao SPC/Serasa, ausência de consórcio, com parcelas mensais de valores módicos. 
O financiamento é formalizado por meio da constituição de sociedade em conta de participação. Os sócios participantes são pessoas simples, iludidos pela promessa de concessão de recursos financeiros para aquisição da casa própria e não tem consciência a respeito do fato de que estão contratando uma sociedade e não um empréstimo.

A promessa do sócio ostensivo envolve a liberação de crédito após o pagamento de determinadas parcelas do "financiamento".

Ocorre que, após o pagamento das parcelas acordadas, o crédito não era liberado para os sócios participantes/mutuários, o que, em diversos casos ensejou o ajuizamento de ação judicial.

As decisões judiciais a respeito das operações elencadas acima evoluiram com o decorrer dos anos, de forma que os Desembargadores passaram a entender que não se tratava apenas de rescisão contratual/prestação de contas com consequente ressarcimento de eventuais danos materiais, mas também de conduta fraudulenta, ensejadora, inclusive, de consequências criminais.

Assim, os tribunais pátrios passaram a entender que o contrato celebrado pelas partes nestes casos não constituíram sociedade em conta de participação, já que os sócios participantes nunca tiveram a intenção de participar dos resultados da sociedade, mas sim de adquirir uma casa própria.

Pela análise dos julgados a respeito do tema, percebe-se - e foi reconhecida - que a intenção dos sócios ostensivos ao formalizar o financiamento via celebração de sociedade em conta de participação consiste, principalmente, em evitar a aplicação: (i) do Código de Defesa do Consumidor; (ii) da Lei n. ${ }^{\circ} 11.795$, de 08 de outubro de 2008 que dispõe sobre o sistema de consórcio; e (iii) de regras específicas aplicáveis a atividades reguladas, dentre elas as legislações específicas, bem como as regras do Banco Central do Brasil e da Comissão de Valores Mobiliários - CVM aplicáveis a instituições financeiras e a administradoras de carteiras de valores mobiliários. 


\title{
VII.5.3.4.1 Utilização das sociedades em conta de participação para evitar a aplicação do Código de Defesa do Consumidor
}

O tema também foi abordado no procedimento n. ${ }^{\circ}$ 08012.000556/2003-20, do Departamento de Proteção e Defesa do Consumidor - DPDC, especialmente sob a ótica de fraude ao direito do consumidor. ${ }^{264}$

Isto porque, nos casos de oferta de financiamento para aquisição de casa própria, a sociedade em conta de participação foi utilizado para estruturar as relações jurídicas com vistas a evitar a aplicação da Lei n. ${ }^{\circ}$ 8.078, de 11 de setembro de 1990 Código de Defesa do Consumidor.

É evidente que a relação jurídica caracteriza-se como relação de consumo, já que ocorre o fornecimento de um serviço que se enquadra na definição do artigo $3^{\circ}$, caput, ${ }^{265}$ do Código de Defesa do Consumidor, a um consumidor, definido no artigo $2^{\text {o266 }}$ do referido Código, mediante remuneração.

\author{
Conforme mencionado por Marco Antonio Zanellato, ${ }^{267}$
}

mediante o instrumento contratual de sociedade em conta de participação,
constitui-se uma sociedade entre uma empresa (sócio gerente e ostensivo) e o
consumidor (sócio participante e oculto). A finalidade de tal sociedade é a
formação de um fundo social que tem por objetivo a compra ou a construção
de um imóvel; para alcançar a finalidade social, o consumidor interessado
(sócio oculto) obriga-se a integralizar, mensalmente, um valor pré-
estabelecido, equivalente a um percentual do fundo social, fundo este que
nada mais é do que o capital a ser liberado pela empresa (sócio ostensivo)
para o cumprimento do fim social. Na prestação mensal está embutido
percentual que chega a 19\% ou mais da prestação, a título de despesas de
manutenção e pró-labore, por conta do gerenciamento do fundo social. É a
remuneração da empresa pela gerência desse fundo, cuja liberação não tem
data prevista, ficando condicionada ao caixa da administradora, isto é, à

\footnotetext{
${ }^{264}$ Disponível em: <www.portal.mj.gov.br>. Acesso em: 01 fev. 2013.

${ }^{265}$ Lei n. $^{\circ} 8.078$, de 11 de setembro de 1990, art. $3^{\circ}$. "Fornecedor é toda pessoa física ou jurídica, pública ou privada, nacional ou estrangeira, bem como os entes despersonalizados, que desenvolvem atividade de produção, montagem, criação, construção, transformação, importação, exportação, distribuição ou comercialização de produtos ou prestação de serviços.

${ }^{266}$ Art. $2^{\circ}$. "Consumidor é toda pessoa física ou jurídica que adquire ou utiliza produto ou serviço como destinatário final. Parágrafo único. Equipara-se a consumidor a coletividade de pessoas, ainda que indetermináveis, que haja intervindo nas relações de consumo.

${ }^{267}$ ZANELLATO, Marco Antonio. Uma nova prática abusiva no mercado de consumo. Disponível em: <www.mp.gov.br/portal/page/.../Artigo-SocContadePaticipação.doc>. Acesso em: 29 jun. 2012.
} 
disponibilidade de recursos obtidos com o recebimento das prestações dos sócios participantes.

Nos termos do procedimento administrativo n. ${ }^{\circ}$ 08012.000556/2003-20, do Departamento de Proteção e Defesa do Consumidor - DPDC:

\begin{abstract}
Em verdade, percebe-se que a relação jurídica em questão não tem efetiva natureza associativa, não se manifesta nem oferece a real possibilidade de obtenção de lucro por parte de um dos sócios, ou melhor definindo, do consumidor. Trata-se de um ardil, mediante oferta pública e difusa convidando consumidores para a aquisição da casa própria, notadamente uma das maiores aspirações da população brasileira. Esse estratagema tem por evidente objetivo transformar o consumidor em "sócio oculto" dessa pretensa sociedade, impondo-lhe a obrigação de pagar uma quantia supostamente a título de integralização do capital social, mas que de fato consiste no preço do imóvel. Com efeito, a dissimulação de uma situação jurídica em outra para escapar do rigor ou da proteção social de determinada norma não é novidade no Brasil, tal como amiúde já ocorre, por exemplo, com empregadores que travestem o vínculo empregatício em cooperativa de trabalho. (...) Como visto, o aspecto formal não pode prevalecer sobre a realidade fática. Assim, não basta que o consumidor esteja rotulado de sócio e formalmente anexado a uma sociedade por conta de participação para que seja afastado o vínculo de consumo. Em outros termos, havendo um fornecedor de produto ou serviço (art. $3^{\circ}, \mathrm{CDC}$ ), mediante remuneração, e um consumidor (arts. $2^{\circ}$, caput e parágrafo único, 17 e 29), haverá relação de consumo, bem como a incidência da Lei 8.078/90.
\end{abstract}

Ainda a respeito da utilização das sociedades em conta de participação como forma de burlar os direitos dos consumidores, foi possível identificar denúncias tais como a apresentada à Secretaria Executiva do PROCON de Minas Gerais por suposta infração de normas de proteção de consumidores. ${ }^{268}$

A denúncia ocorreu pelo fato dos denunciantes veicularam propaganda tida como enganosa quando do oferecimento, aos consumidores, da possibilidade de, em curto espaço de tempo, adquirir, construir ou reformar imóveis. Os panfletos publicitários informavam que não seriam necessárias consultas a cadastros restritivos de crédito, a apresentação de fiador ou a comprovação de renda. Tal estrutura seria formalizada via constituição de sociedade em conta de participação na qual o consumidor figuraria como sócio participante. ${ }^{269}$

\footnotetext{
${ }^{268}$ Informações obtidas no website do Procon de Minas Gerais, mediante contato telefônico e via e-mail com funcionários do referido órgão durante o mês de janeiro de 2013.

${ }^{269}$ Conforme $\quad$ Decisão $\quad$ Administrativa $\quad 207 / 2004, \quad$ disponível <www.mp.rs.gov.br/consumidor/jurisprudencia/id3142.htm?impressao=1>. Acesso em: 09 jan. 2013.
} 
A análise dos julgados constantes no Anexo II a este trabalho permite concluir que os tribunais pátrios têm reconhecido a aplicação do Código de Defesa do Consumidor nos casos em que a sociedade em conta de participação foi utilizada de forma fraudulenta para estruturar a concessão de financiamentos para aquisição da casa própria.

Por fim, é importante mencionar que a utilização das sociedades em conta de participação para os fins dispostos neste item ensejou a elaboração do Projeto de Lei n. ${ }^{\circ}$ 10, de 2005, que pretende acrescentar inciso XVII ao artigo 51 do Código de Defesa do Consumidor para o fim de prever que será nula de pleno direito as cláusulas relativas ao fornecimento de produtos e serviços

que resultem na inclusão automática do consumidor, na qualidade de sócio, ostensivo ou oculto, cotista ou acionista de qualquer modalidade de sociedade comercial, inclusive na denominada sociedade em conta de participação.

\section{VII.5.3.4.2 Utilização das sociedades em conta de participação para evitar a aplicação da Lei n. ${ }^{0}$ 11.795/2008, que dispõe sobre o sistema de consórcio}

As sociedades em conta de participação também são utilizadas de forma fraudulenta para mascarar o que, na verdade, seria um verdadeiro consórcio, disciplinado pela Lei n. ${ }^{\circ} 11.795$, de 08 de outubro de 2008.

A Lei n. ${ }^{\circ} 11.795 / 2008$ prevê, em seus artigos $2^{\circ}$ e $3^{\circ}$, que consórcio é a reunião de pessoas naturais e jurídicas em grupo, com prazo de duração e número de cotas previamente determinados, promovida por administradora de consórcio, com a finalidade de propiciar a seus integrantes, de forma isonômica, a aquisição de bens ou serviços, por meio de autofinanciamento. E, ainda, que Grupo de consórcio é uma sociedade não personificada constituída por consorciados para os fins estabelecidos acima. $^{270}$

\footnotetext{
${ }^{270}$ Disponível em: <www.planalto.gov.br>. Acesso em: 12 dez. 2013.
} 
Os consórcios estão sujeitos a normatização, a coordenação, a supervisão, a fiscalização e o controle do Banco Central do Brasil, conforme previsto no artigo $6^{\circ}$ da Lei n. ${ }^{\circ} 11.795 / 2008$.

De acordo com o levantamento jurisprudencial apresentado no Anexo II deste trabalho, verifica-se que as sociedades em conta de participação estão sendo utilizadas para formalizar verdadeiros consórcios e, assim, para burlar a fiscalização do Banco Central do Brasil - Bacen. ${ }^{271}$

A este respeito, vide, a título exemplificativo, os seguintes julgados analisados no Anexo II a este trabalho: (i) TJRJ, Apelação Cível n. ${ }^{\circ}$ 001236778.2005.8.19.0001, rel. Des. Eduardo Gusmão Alves de Brito Neto, j. 07.05.2012; (ii) TJRJ, Agravo Inominado na Apelação Cível n. ${ }^{\circ}$ 0042893-57.2007.8.19.0001, rel. Des. Mario Robert Mannheimer, j. 22.02.2011; (iii) TJRJ, Apelação n. ${ }^{\circ}$ 001067334.2002.8.26.0050, rel. Des. Luiz Antonio Cardoso, j. 19.07.2011; (iv) TJSP, Apelação n. ${ }^{\circ}$ 0010673-34.2002.8.26.0050, rel. Des. Luiz Antonio Cardoso, j. 19.07.2011; (v) TJSP, Embargos de Declaração n. ${ }^{\circ}$ 9199008-29.2005.8.26.0000/50000, rel. Des. Alberto Mariz de Oliveira, j. 26.06.2012; (vi) TJSP, Apelação n. ${ }^{\circ}$ 000909541.2011.8.26.0011, rel. Des. Luiz Ambra, j. 30.01.2013; (vii) STJ, Conflito de Competência n. ${ }^{\circ} 41.915$ - SP, rel. Ministro Arnaldo Esteves Lima, j. 13.12.2004.

\footnotetext{
${ }^{271}$ Os artigos $6^{\circ}$ e $7^{\circ}$ da Lei n. $.^{\circ} 11.795 / 2008$ dispõe que:

Art. $6^{\circ}$. A normatização, coordenação, supervisão, fiscalização e controle das atividades do sistema de consórcios serão realizados pelo Banco Central do Brasil.

Art. $7^{\circ}$. Compete ao Banco Central do Brasil: I - conceder autorização para funcionamento, transferência do controle societário e reorganização da sociedade e cancelar a autorização para funcionar das administradoras de consórcio, segundo abrangência e condições que fixar; II - aprovar atos administrativos ou societários das administradoras de consórcio, segundo abrangência e condições que fixar; III - baixar normas disciplinando as operações de consórcio, inclusive no que refere à supervisão prudencial, à contabilização, ao oferecimento de garantias, à aplicação financeira dos recursos dos grupos de consórcio, às condições mínimas que devem constar do contrato de participação em grupo de consórcio, por adesão, à prestação de contas e ao encerramento do grupo de consórcio; IV - fixar condições para aplicação das penalidades em face da gravidade da infração praticada e da culpa ou dolo verificados, inclusive no que se refere à gradação das multas previstas nos incisos V e VI do art. 42; V fiscalizar as operações de consórcio, as administradoras de consórcio e os atos dos respectivos administradores e aplicar as sanções; VI - estabelecer os procedimentos relativos ao processo administrativo e o julgamento das infrações a esta Lei, às normas infralegais e aos termos dos contratos de participação em grupo de consórcio, por adesão, formalizados; VII - intervir nas administradoras de consórcio e decretar sua liquidação extrajudicial na forma e condições previstas na legislação especial aplicável às instituições financeiras.

Os dispositivos legais mencionados acima estão disponíveis em: <www.planalto.gov.br>. Acesso em: 12. dez. 2013.
} 
O Anexo II contém a descrição de julgado que menciona, inclusive, a conversão da sociedade em conta de participação em consórcio. ${ }^{272}$

Diante da situação descrita acima, o Banco Central do Brasil - Bacen emitiu o Comunicado n. ${ }^{\circ} 9.609$, de 12 de julho de 2002 a respeito do tema. ${ }^{273}$

Por meio do referido Comunicado, o Banco Central do Brasil - Bacen transmitiu orientação no sentido de que as sociedades em questão deveriam se regularizar mediante: (i) a solicitação de autorização ao Banco Central do Brasil Bacen; (ii) a conversão das relações jurídicas contratadas em consórcio; ou (iii) a dissolução dos grupos já formados.

\title{
VII.5.3.4.3 Utilização das sociedades em conta de participação para evitar a aplicação de regras próprias aplicáveis a atividades reguladas
}

A pesquisa realizada para fins desta dissertação também identificou a utilização de sociedade em conta de participação para formalizar atividades próprias de administradoras de carteiras de valores mobiliários. Neste sentido, vide comunicado da Comissão de Valores Mobiliários - CVM:274

\begin{abstract}
CVM determina suspensão de veiculação de oferta de serviços de administração de carteiras de valores mobiliários pela Inside Administradora e Participações Ltda. - ME, Inside Gestão de Recursos Ltda., por Edmar de Assis, Edmilson de Assis e Anderson de Almeida
\end{abstract}

\footnotetext{
${ }^{272}$ TJSP, Apelação n. ${ }^{\circ}$ 9224667-35.2008.8.26.0000, rel. Des. Lino Machado, j. 14.08.2012.

273 O referido Comunicado prevê que: “(...) Em face da propaganda, constituição e funcionamento de grupos organizados por meio de sociedades em conta de participação e que visam a aquisição de bens, esclarecemos que tais práticas, levadas a cabo por sócio ostensivo de sociedade em conta de participação, sem prévia autorização nos termos dos arts. $7^{\circ}$ e $8^{\circ}$ da Lei 5.768, de 20 de dezembro de 1971 , e 33 da Lei 8.177, de $1^{\circ}$ de março de 1991, carecem de amparo legal. Assim, informamos que as empresas que vêm arregimentando grupos para as operações acima configuradas deverão regularizar sua situação de imediato, segundo as seguintes alternativas: I - solicitar ao Banco Central do Brasil autorização para administrar grupos de consórcio, consoante o disposto na Circular 3.070, de 7 de dezembro de 2001; II converter os grupos já formados para a modalidade de consórcio de imóveis, transferindo-os para administradoras de consórcio autorizadas pelo Banco Central do Brasil, ficando a cargo do sócio ostensivo a responsabilidade pelos custos dessa conversão; ou III - dissolver os grupos já formados, garantindo-se os direitos dos atuais participantes aos valores já desembolsados, de modo a preservar o poder de compra dessas parcelas." Disponível em: <www.bacen.gov.br>. Acesso em: 12 dez. 2013.

${ }^{274}$ Disponível em: <www.cvm.gov.br>. Acesso em: 12 dez. 2013.
} 
O Colegiado da Comissão de Valores Mobiliários (CVM) determinou, por meio da Deliberação CVM no 704/13, a imediata suspensão da veiculação no Brasil de qualquer oferta de serviços de administração de carteiras de valores mobiliários pela Inside Administradora e Participações Ltda. - ME, Inside Gestão de Recursos Ltda., por Edmar de Assis, Edmilson de Assis e Anderson de Almeida.

A Autarquia constatou que a Inside Administradora e Participações Ltda. - ME, Inside Gestão de Recursos Ltda., Edmar de Assis, Edmilson de Assis e Anderson de Almeida vinham utilizando os endereços na Internet http://www.insideadmin.com.br e http://www.facebook.com para ofertar publicamente serviços de administração de carteiras de valores mobiliários, por intermédio de Sociedade em Contas de Participação.

Como a Inside Administradora e Participações Ltda. - ME, Inside Gestão de Recursos Ltda., Edmar de Assis, Edmilson de Assis e Anderson de Almeida não se encontram registrados na CVM, na qualidade de administradores de carteiras de valores mobiliários, a deliberação tem o objetivo de suspender essa atuação e alertar ao mercado quanto à oferta irregular.

Ainda foi estabelecido que todos os mencionados não estão autorizados pela Autarquia a exercer quaisquer atividades no mercado de valores mobiliários e que, por não preencherem os requisitos previstos na regulamentação da CVM, não podem oferecer ao público serviços de administração de carteiras de valores mobiliários.

O descumprimento dessa determinação enseja multa cominatória diária no valor de R\$ 5 mil, sem prejuízo da responsabilidade pelas infrações já cometidas, com a imposição das penalidades cabíveis, nos termos do art. 11 da Lei no 6.385/76.

Esta Comissão solicita aos investidores que recebam propostas de investimento por parte da Inside Administradora e Participações Ltda. - ME, Inside Gestão de Recursos Ltda. de Edmar de Assis, Edmilson de Assis e Anderson de Almeida, que comuniquem o fato por meio do Serviço de Atendimento ao Cidadão (SAC), disponível na página da CVM (www.cvm.gov.br), em "Fale com a CVM". É importante que sejam prestadas informações que detalhem as condições da oferta de valores mobiliários e que permitam a correta identificação das pessoas envolvidas, inclusive para configurar o eventual descumprimento da determinação de suspensão das referidas condutas.

A CVM ainda esclarece que não tem o poder de determinar o ressarcimento de eventuais prejuízos de pessoas que aderiram à oferta irregular em questão, uma vez que sua atuação ocorre no âmbito administrativo. No entanto, a Autarquia pode aplicar as penalidades previstas no art. 11 da Lei 6.385/76 e comunicar ao Ministério Público quando os fatos apurados contiverem indícios da ocorrência de infração à lei penal.

Em caso de eventual prejuízo, a indenização deve ser perseguida junto ao Poder Judiciário. Nessa hipótese, esta Comissão poderá 
ser intimada, pelo Juízo, a oferecer parecer ou prestar esclarecimentos sobre a questão, nos termos do art. 31 da Lei $n^{\circ}$ $6.385 / 76$.

Também a respeito deste tema, os Processos Administrativos CVM n. ${ }^{\circ}$ RJ2011-5848, CVM n. ${ }^{\circ}$ SP-2011-236 e CVM n. ${ }^{\circ}$ RJ 2011-11389 tratam de reclamação de investidores a respeito de sociedade em conta de participação na qual a Powerinvest Negócios \& Participações Ltda., na qualidade de sócia ostensiva, exercia atividade típica de administradora de carteira de valores mobiliários. ${ }^{275}$

A Comissão de Valores Mobiliários - CVM entendeu que a Powerinvest Negócios \& Participações Ltda. exercia atividade típica de administradora de carteira de valores mobiliários, já que: (i) investe recursos aportados por investidores em instrumentos derivativos relacionados aos mercados futuros e de opções de commodities; (ii) exerce a referida atividade com habitualidade; (iii) recebe remuneração relacionada a taxa de performance.

Diante do exposto acima, os Processos Administrativos CVM n. ${ }^{\circ} \mathrm{RJ}-2011$ 5848, CVM n..$^{\circ}$ SP-2011-236 e CVM n. ${ }^{\circ}$ RJ 2011-11389 culminaram na Deliberação CVM 674/11, por meio da qual a Comissão de Valores Mobiliários - CVM determinou a imediata suspensão das atividades de administração de carteira de valores mobiliários pela Powerinvest Negócios \& Participações Ltda. e seus sócios.

VII.6 A utilização das sociedades em conta de participação como forma de instrumentalizar contratos de investimento coletivo sem a observância das regras referentes à emissão, distribuição, negociação e intermediação de valores mobiliários

Conforme exposto acima, nos tempos hodiernos, em determinados casos, há um desvirtuamento no que se refere à utilização das sociedades em conta de participação.

${ }^{275}$ Disponível em: <www.cvm.gov.br>. Acesso em: 12 dez. 2013. 
Além dos casos de fraude em operações de financiamento para aquisição de casa própria, conforme exposto em VII.3, acima, este item VII.6 analisará de forma mais pormenorizada os aspectos jurídicos decorrentes da utilização fraudulenta de sociedade em conta de participação em outros tipos de operação, especialmente as relacionadas a oferta de valores mobiliários.

Isto porque as sociedades em conta de participação têm sido utilizadas, em determinados casos, como produto lançado pelo mercado com características próprias de verdadeiros valores mobiliários, conforme previsto no inciso IX do artigo $2^{\circ}$ da Lei n. ${ }^{\circ} 6.385$, de 07 de dezembro de 1976.

Nestes casos, os sócios ostensivos emissores de contratos de investimento coletivo deveriam estar sujeitos ao regime de plena disponibilização de documentos (full disclosure) e deveriam ser fiscalizadas pela Comissão de Valores Mobiliários CVM.

Para tratar deste tema, o item VII.6.1 inicialmente analisará a origem e histórico dos contratos de investimento coletivo no Brasil e sua bagagem oriunda do direito norte-americano. O item VII.6.2 delimitará o conceito de contrato de investimento coletivo. Em seguida, o item subsequente, numerado como VII.6.3, abordará o enquadramento dos contratos de investimento coletivo como valores mobiliários. Por fim, pretende-se analisar a utilização de sociedades em conta de participação para estruturar contratos de investimento coletivo.

\section{VII.6.1 Origem e histórico do conceito de valores mobiliários e de contrato de investimento coletivo}

\section{VII.6.1.1 Origem e histórico do conceito de valores mobiliários e de contrato de investimento coletivo no Brasil}

A Lei n. ${ }^{\circ} 6.385 / 1976$ foi elaborada com o objetivo de estruturar o mercado de capitais brasileiro. Para tanto, previu regras referentes à emissão, distribuição, negociação e intermediação de valores mobiliários e, inclusive, previu que tais atos 
relacionados aos valores mobiliários estão sujeitos à fiscalização da Comissão de Valores Mobiliários - CVM.

Diante disto, fez-se necessária a definição de valores mobiliários. Neste contexto, o legislador viu-se diante de um dilema. Por um lado, sabia-se que a definição legal deveria ser ampla, capaz de se adequar às constantes inovações e mutações do mercado. Por outro lado, a definição também deveria ser precisa, para assegurar a previsibilidade necessária para que o mercado pudesse se desenvolver. ${ }^{276}$

Inicialmente, a Lei n. ${ }^{\circ}$ 6.385/1976 fixou uma lista exaustiva de valores mobiliários e, para resolver o impasse exposto acima, conferiu ao Conselho Monetário Nacional - CMN - competência para alterar a lista taxativa.

A Lei n. ${ }^{\circ} 10.303$, de 31 de outubro de 2001 incorporou o conceito fixado pela Medida Provisória n. ${ }^{\circ} 1.637 / 98$ à Lei n. ${ }^{\circ}$ 6.385/1976 e acrescentou, apenas, o requisito de que os títulos ou contratos de investimento coletivo, para serem caracterizados como valores mobiliários, devem ser ofertados publicamente.

Com isto, o artigo $2^{\circ}$, inciso IX, da Lei n. ${ }^{\circ}$ 6.385/1976 passou a contar com a seguinte redação, que introduz o conceito de contratos de investimento coletivo:

\footnotetext{
Art. $2^{\circ}$. São valores mobiliários sujeitos ao regime desta Lei:

(...)

IX - quando ofertados publicamente, quaisquer outros títulos ou contratos de investimento coletivo, que gerem direito de participação, de parceria ou de remuneração, inclusive resultante de prestação de serviços, cujos rendimentos advêm do esforço do empreendedor ou de terceiros.
}

Diante disto, a legislação brasileira a respeito do mercado de capitais passou a abarcar não apenas uma lista detalhada de valores mobiliários, mas também uma hipótese genérica, apta a enquadrar os produtos criados pela dinâmica do mercado que possuem as características de valores mobiliários, e que, portanto, devem ser fiscalizados pela Comissão de Valores Mobiliários - CVM.

\footnotetext{
276 Cf. voto do Diretor Marcos Barbosa Pinto no Processo CVM RJ 2007/11.593. Disponível em: <www.cvm.gov.br>. Acesso em: 02 jun. 2011.
} 
A solução do legislador brasileiro foi inspirada no conceito de security e no Howey Test do direito americano. Por esta razão, o item VII.6.1.2, abaixo, abordará a origem e histórico do conceito de security no direito norte-americano.

\section{VII.6.1.2 Origem e histórico do conceito de security nos Estados Unidos da América}

Tendo em vista o entendimento de que o conceito de valores mobiliários constante na Lei n. $^{\circ}$ 6.375/1976 teve origem no direito norte-americano, este item abordará, de forma breve, determinadas considerações a respeito do surgimento e evolução do conceito de security nos Estados Unidos da América.

Até 1933 não havia, no direito norte-americano, um tratamento uniforme a respeito das securities, sendo certo que o referido tema era regulado apenas pelas chamadas Blue Sky Laws, ou seja, pelas diferentes legislações estaduais. A preocupação das Blue Sky Laws era mais voltada para a regulação das securities como meio de evitar fraude do que para a regulação voltada a disciplinar a utilização deste instrumento pelo mercado.

Com a crise de 1929, surgiram o Securities Act, de 1933, e o Securities Exchange Act, de 1934. O Securities Act de 1933 foi o diploma legal precursor da positivação do conceito de securities.

Ocorre que a definição do conceito de securities proveniente do Securities Act foi no sentido de apresentar uma extensa lista de títulos, valores ou contratos que poderiam ser entendidos como valores mobiliários. O referido diploma legal não delimitou um conceito geral para o instituto. A tarefa de delimitar a definição de valor mobiliário coube, desta forma, aos tribunais norte-americanos.

Apesar de não ter sido o primeiro caso a ser julgado, o leading case da matéria foi o caso SEC v. W. J. Howey \& Co, de 1946. Isto porque, no âmbito desta decisão, a Suprema Corte dos EUA definiu os primeiros contornos do conceito de "contrato de investimento coletivo" e de seu enquadramento como valor mobiliário. 
Neste contexto, no caso referido acima, a Suprema Corte dos Estados Unidos da América decidiu que para a caracterização do contrato de investimento coletivo e, portanto, para a caracterização de valor mobiliário, a forma do negócio é subsidiária, interessando, portanto, a realidade econômica.

Diante disto, a Suprema Corte dos Estados Unidos forneceu alguns critérios para análise das situações concretas de forma a avaliar a eventual caracterização do título ou contrato como um verdadeiro contrato de investimento coletivo. A referida listagem de critérios fixados pela Suprema Corte Americana ficou conhecida como Howey Test ou Howey Definition.

A Suprema Corte Americana fixou os seguintes critérios para a caracterização de contrato de investimento: (a) todo investimento em dinheiro ou em bens suscetíveis de avaliação monetária, (b) realizado pelo investidor em razão de uma captação pública de recursos, (c) de modo a fornecer capital de risco a um empreendimento, (d) em que ele, o investidor, não tem ingerência direta, (e) mas do qual espera obter algum ganho ou benefício futuro. ${ }^{277}$

A adoção de um conceito amplo de valor mobiliário apresenta uma vantagem clara, a saber, a possibilidade, conforme ressaltado pela Suprema Corte dos EUA, de se analisar o caso concreto, independente da forma ou da denominação do negócio. Possibilita, assim, abarcar a constante evolução do mercado, sem a necessidade de se reformar a legislação sempre que a criatividade negocial formular novos produtos. De outro lado, como também anotou a Suprema Corte dos EUA, a definição não pode ser tão ampla a ponto abranger todo e qualquer negócio.

\footnotetext{
${ }^{277}$ A este respeito, vide excerto de Paulo Fernando Campos Salles de Toledo: "Dos elementos apontados no Howey Test, certamente o que mais caracteriza, e individualiza, as "securities", é a assertiva de que os resultados do empreendimento devem advir "solely through the efforts of others", restringindo-se a participação do investidor ao fornecimento de capital. Quanto a este ponto, cumpre notar ter sido discutida a noção de ausência de participação, ou em outros termos, se seria possível ao investidor ter alguma intervenção, ainda que limitada, nos negócios sociais, sendo esta a idéia que veio a prevalecer (sem qualquer enfraquecimento, no entanto, do critério de investimento passivo)." TOLEDO, Paulo Fernando Campos Salles de. Valores Mobiliários - Inteligência do artigo 2º , N. III da Lei 6.385, de 1976. Justitia. São Paulo, RT, jul./set. 1983, p. 176-184.
} 
Ademais, a Suprema Corte norte-americana, no julgamento do caso Marine Bank v. Weaver, emitiu decisão no sentido de que os certificados de depósito bancário emitidos pela referida instituição financeira não deveriam ser enquadrados como valores mobiliários. Isto porque os títulos não eram negociados publicamente e, importante, tais certificados já eram regulados pela legislação federal bancária. O citado Tribunal argumentou que as partes envolvidas já estavam devidamente protegidas e, por esta razão, não haveria necessidade de se aplicar a regulação ou a fiscalização pertinente aos valores mobiliários.

Com a edição da Medida Provisória n. ${ }^{\circ}$ 1.637/1998, convertida na Lei n. ${ }^{\circ}$ 10.198/2001 a nossa legislação caminhou no mesmo sentido e adotou um conceito geral de valor mobiliário capaz de abarcar títulos ou contratos de investimento coletivo não necessariamente definidos em uma lista taxativa.

Diante disto, vemos que o legislador pátrio estabeleceu determinados critérios para o enquadramento de um título ou contrato na cláusula geral de valores mobiliários.

\section{VII.6.1.3 Conceito de contrato de investimento coletivo}

Conforme exposto acima, a Lei n. ${ }^{\circ}$ 10.303, de 31 de outubro de 2001 incorporou o conceito fixado pela Medida Provisória n. ${ }^{\circ} 1.637 / 1998$ à Lei n. ${ }^{\circ}$ 6.385/1976 e, com isso, introduziu, na legislação brasileira, o atual conceito de contrato de investimento coletivo.

Os contratos de investimento coletivos podem ser caracterizados como títulos lastreados em quaisquer produtos ou subprodutos destinados à comercialização e que geram direito de participação, parceria ou remuneração, inclusive de prestação de serviços, cujos rendimentos advêm do esforço do empreendedor ou de terceiros. 


\section{VII.6.1.4 A caracterização dos contratos de investimento coletivo como valores mobiliários}

A partir do histórico elencado no item VII.6.1.1, acima, é possível afirmar que o conceito genérico de valor mobiliário, previsto no inciso IX do artigo $2^{\circ}$ da Lei n. ${ }^{\circ}$ $6.385 / 1976$, fixou os seguintes requisitos para que um determinado produto lançado pela dinâmica do mercado e da economia possa ser caracterizado como "valor mobiliário" e, portanto, estar sujeito à fiscalização da Comissão de Valores Mobiliários - CVM: ${ }^{278}$

(i) Deve haver um investimento (IX - ... quaisquer títulos ou contratos de investimento coletivo ...);

(ii) $\mathrm{O}$ investimento deve ser formalizado por um título ou contrato (IX - ... quaisquer títulos ou contratos de investimento coletivo...);

(iii) $\mathrm{O}$ investimento deve ser coletivo, ou seja, diversos investidores devem destinar sua poupança para a aquisição do referido produto (IX - ... títulos ou contratos de investimento coletivo...);

(iv) O investimento deve possibilitar alguma espécie de participação, parceria ou remuneração (IX - ... títulos ou contratos de investimento coletivo que gerem direito de participação, parceria ou remuneração...);

(v) A remuneração dever ter origem nos esforços do empreendedor ou de terceiros que não o investidor (IX - ... cujos rendimentos advêm do esforço do empreendedor ou de terceiros); $\mathrm{e}$

(vi) Os títulos devem ser objeto de oferta pública (IX - ... quando ofertados publicamente...).

O $\S 1^{\circ}$ do artigo $2^{\circ}$ da Lei n. $^{\circ} 6.385 / 1976$ prevê, por sua vez, que não são valores mobiliários os títulos da dívida e os títulos de responsabilidade das instituições financeiras.

\footnotetext{
${ }^{278}$ Também cf. voto do Diretor Marcos Barbosa Pinto no Processo CVM RJ 2007/11.593, rel. Marcos Barbosa Pinto, j. 15.01.2008.
} 
Além disto, entendemos ser importante mencionar que o artigo $2^{\circ}$ da Instrução CVM n. ${ }^{\circ} 296$, de 18 de dezembro de 1998, prevê que: ${ }^{279}$

constituem valores mobiliários, sujeitos ao regime da Lei $\mathrm{n}^{\mathrm{o}} 6.385$, de 7 de dezembro de 1976, quando ofertados publicamente, contratos de investimento coletivo, que gerem direito de participação, de parceria ou de remuneração, inclusive resultante de prestação de serviços, cujos rendimentos advêm do esforço do empreendedor ou de terceiros.

\section{VII.6.1.5 A utilização da sociedade em conta de participação para estruturar contratos de investimento coletivo}

Até o presente momento, já foram identificadas ações especulativas que envolviam sociedades em conta de participação estruturadas como verdadeiros contratos de investimento coletivo e que resultaram em prejuízos relevantes a investidores.

Este subitem colacionará determinados casos práticos nos quais as sociedades em conta de participação foram utilizadas como instrumento de captação de recursos apto a caracterizar verdadeiro valor mobiliário.

Como exemplo, podemos citar o alerta ao mercado divulgado pela Comissão de Valores Mobiliários - CVM a respeito da utilização de sociedade em conta de participação para formalizar verdadeiros contratos de investimento coletivo cujo objeto envolveria a participação de investidores em direitos federativos de jogadores de futebol. $^{280}$

In verbis:

\section{CVM ALERTA INVESTIDORES PARA OS RISCOS DE INVESTIMENTO EM PARTICIPAÇÃO EM DIREITOS FEDERATIVOS DE JOGADORES DE FUTEBOL}

A Comissão de Valores Mobiliários comunica ao público que verificou, através de inspeções realizadas, a ocorrência de situações que podem configurar captação irregular de poupança

\footnotetext{
${ }^{279}$ Disponível em: <www.planalto.gov.br>. Acesso em: 02 jun. 2011.

280 Disponível em: <http://www.cvm.gov.br/port/alertas/ALERTA_PALESTRA-GUARANI.asp >. Acesso em: 25 nov. 2013.
} 
popular, por meio da oferta ao público de oportunidades de investimento em "direitos federativos" de atletas profissionais da Sociedade Esportiva Palmeiras e do Guarani Futebol Clube.

Nas situações identificadas, os recursos entregues pelos investidores seriam utilizados em benefício dos clubes de futebol detentores dos "direitos federativos" dos atletas. Em contrapartida ao aporte, os investidores teriam o direito de participar dos futuros resultados econômicos advindos da valorização dos jogadores a que se referem os "direitos federativos". Os investimentos seriam oferecidos por meio de sociedades em conta de participação, sendo as condições gerais do investimento previstas em contrato que formalizaria as hipóteses de reembolso e rendimento, a depender da valorização dos "direitos federativos" dos atletas.

$\mathrm{O}$ art. 19 da Lei $\mathrm{n}^{\circ}$ 6.385/76 estabelece a necessidade do registro da CVM para qualquer oferta pública de valores mobiliários, inclusive quando se tratar de contratos de investimento coletivo, que gerem direito de participação, de parceria ou de remuneração, cujos rendimentos advêm do esforço do empreendedor ou de terceiros (art. $2^{\circ}$, inc. IX, da Lei 6.385/76), como seria o caso do investimento em sociedades em contas de participação relacionadas aos "direitos federativos" de jogadores de futebol, caso ele venha a ser oferecido ao público. Tal atividade, nos termos da lei, somente pode ser realizada por empresas devidamente registradas perante a CVM, através de distribuição pública igualmente registrada.

A CVM alerta aos referidos clubes que se abstenham de realizar ofertas como as aqui descritas, sem que fique assegurada a fiel observância da legislação em vigor e obtidos os necessários e prévios registros na CVM.

Ademais, alertamos àqueles que eventualmente sejam procurados com tal tipo de proposta que ofertas com as características acima referidas exigem prévio registro na CVM e devem ser analisadas com cautela pelo público investidor, por constituírem uma possível relação de investimento, em que a racionalidade deve sempre prevalecer. Finalmente, recomendamos a tais investidores que comuniquem tal fato à CVM, de modo a contribuir para a pronta atuação da Autarquia na proteção e defesa dos investidores e do respeito à legislação em vigor.

Ademais, é importante mencionar a Deliberação CVM n. ${ }^{\circ}$ 495, de 03 de janeiro de $2006{ }^{281}$

In verbis:

A CVM constatou que a Tropical Flora Reflorestadora Ltda., inscrita no C.N.P.J./M.F. sob o ${ }^{\circ}$ 05.975.518/0001-64, sediada

${ }^{281}$ O Processo Administrativo CVM n. ${ }^{\circ}$ RJ/2010/8603 aborda o mesmo assunto e foi instaurado em decorrência da reincidência da Tropical Flora Reflorestadora Ltda. em praticar os atos objeto da Deliberação CVM n. ${ }^{\circ}$ 495, de 03 de janeiro de 2006. 
na Estrada Vicinal Fernão a Rodovia SP 294, Km.5, s/no, no Município de Fernão, São Paulo, e com escritório no município de Santo André, na Av. José Caballero, 261, Cj.71, que tem como sócios Pedro Aparecido Ciriello, inscrito no C.P.F. sob o $\mathrm{n}^{\circ}$ 250.306.638-00, e Valéria Ciriello, inscrita no C.P.F./M.F. sob o $\mathrm{n}^{\mathrm{o}}$ 163.530.748-16, não registrada ou autorizada por esta Comissão a emitir publicamente valores mobiliários, vem oferecendo, em sua página na rede mundial de computadores (http://www.tropicalflora.com.br), e também em prospecto nas versões em português e inglês, oportunidade de investir em empreendimento cujo nome fantasia é "Projeto Luvre", relacionado com a exploração econômica da atividade de reflorestamento de uma árvore denominada "Guanandi", utilizando-se de apelo ao público para adesão a uma "Sociedade em Conta de Participação", mediante o preenchimento e a assinatura de "Proposta de Participação" disponível na mesma página na Internet, que tem como sócia ostensiva a Tropical Flora Reflorestadora Ltda. e cujo objeto é a parceria rural voltada para essa cultura, sendo o produto da venda das árvores rateado proporcionalmente entre os participantes;

A oferta ao público de modalidade de investimento em dinheiro, com vistas ao fornecimento de capital de risco a um empreendimento em que o investidor não tem ingerência, mas do qual espera obter ganho (lucro), por meio de proposta de participação referida na letra "a" acima, associada (i) à divulgação de "rentabilidade certa e investimento sólido", "investimento de baixo risco", "excelente opção para contrabalançar o risco de uma carteira de investimentos", de afirmação de que o patrimônio do investidor poderá corresponder a 98,15 vezes o capital inicial investido em alguns casos; e (ii) à previsão de que a Tropical Flora Reflorestadora Ltda., sócia ostensiva, poderá admitir novos sócios sem o consentimento dos demais sócios; configura modalidade de contrato de investimento coletivo do agronegócio, nos termos do inciso IX do art. $2^{\circ}$ da Lei $\mathrm{n}^{\circ} 6.385 / 76$, devendo, portanto, sujeitar-se ao regime dessa Lei; e

Em face da legislação em vigor, só podem emitir títulos ou contratos de investimento coletivo para distribuição pública as sociedades constituídas sob a forma de sociedade anônima, devidamente registradas nesta CVM, não estando a Tropical Flora Reflorestadora Ltda. habilitada a ofertar publicamente os contratos de investimento coletivo,

\section{DELIBEROU:}

I - alertar os participantes do mercado de valores mobiliários e o público em geral sobre o fato de que a Tropical Flora Reflorestadora Ltda. não se encontra habilitada a oferecer publicamente quaisquer títulos ou contratos de investimento coletivo, conforme definidos no inciso IX do art. $2^{\circ}$ da Lei $n^{\circ}$ $6.385 / 76$, tendo em vista não estar registrada como emissora de valores mobiliários nesta Comissão;

II - determinar à sociedade referida no item I, bem como a seus sócios e prepostos, que se abstenham de ofertar ao público quaisquer títulos ou contratos de investimento coletivo, sem o devido registro nesta CVM, alertando que a não observância da presente determinação sujeitá-los-á à imposição de multa cominatória diária, no valor de $\mathrm{R} \$ 500,00$ (quinhentos reais), 
sem prejuízo da responsabilidade pelas infrações já cometidas, com a imposição da penalidade cabível, nos termos do art. 11 da Lei $n^{\circ} 6.385 / 76$.

\section{$(\ldots)$}

Outro caso que elucida o tema ora analisado é o abordado no âmbito do Processo Administrativo Sancionador CVM n. ${ }^{\circ}$ RJ 2006/3364, no qual a MTel Tecnologia e seus administradores foram condenados em decorrência da realização de oferta pública de valores mobiliários por meio da utilização de sociedade em conta de participação sem o devido registro na Comissão de Valores Mobiliários - CVM. ${ }^{282}$

\section{A oferta pública da MTel Tecnologia mencionava que o investimento}

possibilita ao interessado ter excelente retorno financeiro ao investir a partir de $\mathrm{R} \$ 50$ mil, com prazos mínimos de 24 meses. O investidor receberá mensalmente o pagamento de parte de devolução do capital investido e o lucro auferido, já a partir do $1^{\circ}$ mês do fechamento do contrato. O retorno médio líquido (já pagos os impostos) do MInvest em 2003 ficou acima de $30 \%$ ao ano.

Na ocasião, a Comissão de Valores Mobiliários - CVM entendeu que os seguintes requisitos dos contratos de investimentos coletivos podiam ser identificados nas sociedades em conta de participação ofertadas: ${ }^{283}$

(i) "o seu oferecimento ao público", o que foi realizado mediante envio de correspondência eletrônica e via publicação na internet; ${ }^{284}$

(ii) "a sua caracterização como título ou contrato de investimento coletivo, que gerem direito de participação, de parceria ou de remuneração, inclusive resultante de prestação de serviços, cujos rendimentos advêm do esforço do empreendedor ou de terceiros", já que a CVM entendeu que as sociedades em conta de participação ofertadas foram utilizadas como mero ajuste contratual para o fim de permitir que os sócios participantes auferissem participações em rendimentos que advém do esforço do empreendedor, o sócio ostensivo.

\footnotetext{
${ }^{282}$ Disponível em: <www.cvm.gov.br>. Acesso em: 25 nov. 2013.

${ }^{283}$ Disponível em: <www.cvm.gov.br>. Acesso em: 25 nov. 2013.

${ }^{284}$ A este respeito, a CVM entendeu que a internet constitui meio de realizar oferta pública, já que a Instrução Normativa CVM 400/2003, que dispõe sobre as ofertas públicas de distribuição de valores mobiliários no mercado primário e secundário, prevê que se caracteriza oferta como pública quando realizada por meios de comunicação de massa ou eletrônicos (páginas ou documentos na rede mundial ou outras redes abertas de computadores e correio eletrônico).
} 
Neste contexto, parece ser indispensável que a Comissão de Valores Mobiliários - CVM reconheça estruturas ousadas de investimento, inclusive as instrumentalizadas por meio de sociedades em conta de participação, que resultam em apelo público à poupança popular, com promessa de remuneração futura sem o cumprimento da legislação aplicável.

Por outro lado, é interessante analisar o entendimento da Comissão de Valores Mobiliários - CVM no sentido de que, nos casos referidos acima, as sociedades em conta de participação constituíram meros ajustes contratuais construídos para o fim de permitir que os sócios participantes auferissem participações em rendimentos que advém do esforço do sócio ostensivo e, portanto, poderiam ser equiparadas a contratos de investimento coletivo.

A este respeito, nos parece que o entendimento da Comissão de Valores Mobiliários - CVM está, em parte, equivocado.

A sociedade em conta de participação constitui verdadeira sociedade e não mero ajuste contratual. A este respeito, vide o Capítulo III desta dissertação. O Código Civil de 2002 reafirmou este fato ao disciplinar as sociedades em conta de participação no capítulo próprio das sociedades despersonificadas.

Nos casos expostos acima, puderam ser verificados todos os requisitos previstos no artigo 981 do Código Civil de 2002, que colaciona os elementos para a caracterização de sociedades, ou seja, duas ou mais pessoas aportaram bens ou serviços para um fim comum e partilharam resultados.

O fato é que os investidores não tinham a intenção de constituir sociedade e sequer atentaram-se a este fato ao assinar o documento proposto pelas sociedades que objetivavam operações fraudulentas.

Não obstante o lapso de enquadrar a sociedade em conta de participação, nos casos de sua utilização como contrato de investimento coletivo, convém frisar que o caráter societário da sociedade em conta de participação não impossibilita a sua utilização como verdadeiro valor mobiliário. 
Há, inclusive, determinados julgados que equiparam os contratos de investimento coletivo a verdadeiras sociedades.

Neste sentido, vide os seguintes excertos de julgados do Tribunal de Justiça do Estado de São Paulo:

“Apelação - Embargos de terceiro - Sentença de extinção do processo sem resolução do mérito, por inadequação da via eleita - Embargos relacionados a execução fundada em contrato de investimento coletivo de engorda de gado bovino, para posterior revenda e repartição dos lucros - Caráter societário da obrigação - Competência recursal tocando a uma dentre as $1^{\mathrm{a}}$ a $10^{\mathrm{a}}$ Câmaras, às quais atribuída a competência da antiga Seção de Direito Privado, consoante o Provimento 63/2004 - Conclusão prestigiada pelo Órgão Especial do Egrégio Tribunal, diante do decidido na Dúvida de Competência de n. ${ }^{\text {o } 147.020 .4 / 4 ~-~ R e g r a s ~}$ de competência recursal de observância obrigatória, como pressuposto indispensável da distribuição especializada e equitativa da função jurisdicional. (Apelação sem Revisão 1190031-0, TJSP, 25 a Câmara de Direito Privado, rel. Des. Ricardo Pessoa de Mello Belli, j. 21.10.2008).

"INCOMPETÊNCIA - Execução por título extrajudicial Contrato de investimento coletivo em engorda de gado bovino, para posterior revenda e repartição dos lucros - Caráter societário da obrigação - Atribuição para julgamento da matéria que é das Câmaras da Seção de Direito Privado numeradas de n. 1 a 10, deste Tribunal de Justiça, do estado de São Paulo Incompetência desta $25^{\circ}$ Câmara da mesma Seção - Embargos de devedor - Extinção anômala do processo - Apelação - Não conhecimento, com ordem de remessa dos autos à redistribuição. (Apelação sem Revisão 1145631-0/9, TJSP, 25 Câmara de Direito Privado, rel. Des. Sebastião Flávio, j. 19.08.2008).

COISA MÓVEL - Contrato de Investimento - Aplicação de dinheiro em gado, para engorda e revenda futura - Caráter societário do negócio - Investidor que assume o risco do resultado econômico do empreendimento - Pretensão à caracterização da operação como singela compra e venda e de parceria rural - Inadmissibilidade - Ausência do direito de restituição da coisa em espécie - Sujeição da investidora aos efeitos da falência - Procedência da ação de resilição Provimento da apelação para reversão do resultado do julgamento. (Apelação sem Revisão 1067833-0/6, TJSP, 25 Câmara de Direito Privado, rel. Des. Sebastião Flávio, j. 19.02.2008).

Há, na verdade, grande similaridade entre sociedade em conta de participação e contratos de investimento coletivo, já que, ambos os institutos possuem determinadas características comuns. 
Dentre as referidas características, é possível citar as seguintes: (i) há duas ou mais pessoas que aportam bens ou serviços para um fim comum e partilham resultados e riscos; (ii) não há garantia de resultado, que pode ensejar lucro ou prejuízo; (iii) são atribuídas diferentes funções à partes; (iv) não possuem personalidade jurídica; (iv) possuem eficácia meramente interna; (v) há transferência de recursos para a esfera patrimonial do empreendedor, ainda que na sociedade em conta de participação os referidos recursos constituam patrimônio especial; (v) possibilidade de emitir certificados em nome do empreendedor (sócio ostensivo), conforme analisado no item III.4.8 para as sociedades em conta de participação e conforme previsto na Lei n. $^{\circ}$ 10.198/2001 para os contratos de investimento coletivo; (vi) possibilidade de remuneração do empreendedor por suas atividades; (vii) liberdade para definição das participações nos resultados. ${ }^{285}$

Conclui-se, portanto que, em determinados casos, as sociedades em conta de participação podem ser caracterizadas como verdadeiros contratos de investimento coletivo.

Nesta hipótese, o sócio ostensivo deverá cumprir as regras que disciplinam os contratos de investimento coletivo.

Há, ainda, uma vertente da doutrina ${ }^{286}$ que defende que, diante das semelhanças mencionadas acima, todo contrato de investimento coletivo é uma sociedade em conta de participação. O contrário não é verdadeiro, já que nem toda sociedade em conta de participação caracteriza-se como contrato de investimento coletivo.

\footnotetext{
${ }^{285}$ Conforme PICCHI, Flávio Augusto. Op. cit., p. 201.

${ }^{286}$ Idem, ibidem.

É importante mencionar que, mesmo que as estruturas do direito societário americano não correspondam às do direito brasileiro, as general partnership têm alguns pontos comuns com as sociedades em conta de participação. A este respeito, vide Robert W. Hamilton: A partnership is a logical extension of a proprietorship where there is more than one owner. (...). There is generally no need for a written agreement and no public filing of any document (...). Most of law of partnership that is discussed in law school courses deals with the rights and duties of partners among themselves rather than the relationship of the partnership to the outside world. (HAMILTON, Robert W. Fundamentals of modern business. Boston: Little Brown. 1989. p. 303-304). A doutrina Americana também já associou as general partnerships às securities. A este respeito, Loss e Seligman: Even interests in something called a general partnership may be securities. (LOSS, Louis; SELIGMAN, Joel. Fundamentals of Securities Regulation. 5. ed. Boston: Little Brown, 2004. p. 194-195)
} 
A principal consequência da caracterização dos contratos de investimento coletivo como sociedade em conta de participação decorre da aplicação dos artigos 991 a 996 do Código Civil de 2002 a todos os contratos de investimento coletivo, o que poderá ensejar o preenchimento de determinadas lacunas não disciplinadas na Lei n. $^{\circ}$ 6.385/76 e na regulamentação da Comissão de Valores Mobiliários - CVM.

Assim, por exemplo, a equiparação dos institutos permite afirmar que o investidor, ao ser classificado como sócio participante, possui uma série de prerrogativas e direitos de fiscalização, conforme previsto no artigo 993, parágrafo único, do Código Civil de 2002.

No que se refere ao patrimônio aportado pelo investidor do contrato de investimento coletivo, deverá ser aplicado o artigo 994 do Código Civil de 2002, de forma que os recursos passariam a integrar a esfera patrimonial do empreendedor/sócio ostensivo como patrimônio especial e, ademais, por consequência, deveriam ser administrados pelo empreendedor/sócio ostensivo com discricionariedade restrita, já que este último age como fiduciário do investidor/sócio participante, conforme detalhado no Capítulo IV deste trabalho. 


\section{CAPÍTULO VIII CONCLUSÕES}

A sociedade em conta de participação pode ser conceituada como aquela em que a atividade constitutiva do objeto social é exercida unicamente pelo sócio ostensivo, em seu nome individual e sob sua própria e exclusiva responsabilidade, participando os demais dos resultados correspondentes.

Quanto à origem desse tipo societário, a posição que prevalece dentre os historiadores e estudiosos de direito é no sentido de que as sociedades em conta de participação surgiram na Idade Média, na Itália, no período das decisões da Rota de Gênova, especialmente em decorrência da proibição da usura pela Igreja Católica e do clima medieval, que dificultava o exercício do comércio pelos nobres.

A origem deste tipo societário está intrinsicamente relacionada aos contratos de commenda que se mantiveram ocultos, ou seja, não registrados, e à evolução desta espécie de negócio jurídico para contratos de sociedade.

O Código Comercial, já parcialmente revogado, foi o diploma legal precursor da positivação da sociedade em conta de participação no Brasil e teve nítida influência dos Códigos Português e Espanhol.

O Código Civil de 2002 expandiu e detalhou o regramento das sociedades em conta de participação ao disciplinar este tipo societário no título II, denominado como "Da sociedade", em subtítulo específico denominado como "Da sociedade não personificada". Com isso, o referido diploma legal corroborou a caracterização da sociedade em conta de participação como verdadeira sociedade sem personalidade jurídica, tema controverso até os dias atuais.

A ausência de personalidade jurídica enseja determinadas características próprias das sociedades em conta de participação, tais como: (i) a ausência de patrimônio próprio, (ii) a impossibilidade de assumir obrigações e ser titular de direitos, (iii) a impossibilidade de ser parte em processo administrativo e judicial, (iv) a ausência de denominação ou firma social, (v) ausência de sede e domicílio. 
Quanto ao patrimônio das sociedades em conta de participação, é importante mencionar que o próprio Código Civil de 2002, em seu artigo 994, o classifica como "patrimônio especial", que pode ser caracterizado como aquele que se destaca do patrimônio geral para satisfazer um fim específico, que deve ser necessariamente perseguido pelo seu titular, ou seja, pelo sócio ostensivo.

O fato de a lei ter designado o fundo social como patrimônio especial corrobora, na visão da autora desta dissertação, o entendimento já tão discutido de que as sociedades em conta de participação são carentes de personalidade jurídica. Caso contrário, nos parece que a legislação pátria teria atribuído a designação de "patrimônio autônomo", expressão típica para designar patrimônio de um novo sujeito, como ocorre na constituição de pessoas jurídicas.

O mesmo artigo 994 do Código Civil de 2002 prevê que o patrimônio especial é composto pela contribuição dos sócios. Essa dissertação procurou demonstrar que a composição do patrimônio especial deveria ser mais ampla e abarcar os rendimentos do fundo social, lucros não distribuídos aos sócios e demais recursos relacionados ao objeto da sociedade em conta de participação.

Além disso, outra discussão a respeito do tema envolve o fato de que o Parágrafo $1^{\circ}$ do Artigo 994 do Código Civil de 2002 prevê que a especialização patrimonial somente produz efeitos em relação aos sócios, o que faz com que: (i) os credores das sociedades em conta de participação não tenham reservado para si o patrimônio especial para execução em caso de inadimplemento; e (ii) os credores particulares do sócio ostensivo e os credores sociais podem perseguir todo o patrimônio do sócio ostensivo, inclusive o patrimônio especial, para satisfação de seu crédito.

Por um lado, essa restrição relacionada à especialização patrimonial somente em relação aos sócios implica em subutilização do instituto. Por outro lado, para a especialização patrimonial surtir efeitos perante terceiros é necessária a sua plena publicidade. Assim, a plena eficácia da especialização patrimonial parece ser incompatível com as características das sociedades em conta de participação, que não estão sujeitas a registro nos órgãos competentes e não são públicas. 
Nesse caso, a especialização patrimonial entre os sócios tem a finalidade de delimitar a responsabilidade do sócio ostensivo no que diz respeito à consecução do objeto social e de responsabilizá-lo em caso de desvio de bens e/ou recursos para a realização de outra finalidade que não as relacionadas ao objeto social.

Ainda com relação à responsabilidade dos sócios, as partes devem respeitar as seguintes diretrizes mínimas: (i) o sócio ostensivo deverá responder de forma ilimitada perante terceiros; e (ii) o sócio participante deverá responder perante o sócio ostensivo com, no mínimo, o valor dos aportes que realizou. Uma vez respeitadas as referidas diretrizes mínimas, entendemos que as partes podem livremente estipular as regras de responsabilidade dos sócios. Nesse ínterim, entendemos que é nula a cláusula do contrato de sociedade em conta de participação que preveja que o sócio participante não participa das perdas e, portanto, não é responsável por eventuais prejuízos aferidos pela sociedade.

A dissolução da sociedade em conta de participação pode ocorrer por fim do prazo pactuado, conclusão do objetivo social, falência do sócio ostensivo e/ou do sócio participante, distrato social, falecimento de um dos sócios, resolução da sociedade em relação a um sócio, impossibilidade de preenchimento de seu fim. Ato contínuo à dissolução, a sociedade deverá ser liquidada, sendo que a figura do liquidante necessariamente coincidirá com o sócio ostensivo, o que faz com que ocorra a peculiaridade de a liquidação ocorrer via prestação de contas, sendo que esse fato não descaracteriza a sua natureza de sociedade.

Além de analisar as características e das peculiaridades deste tipo societário, esta dissertação procurou contribuir para a comunidade acadêmica através do levantamento de informações atuais a respeito da utilização das sociedades em conta de participação.

A partir desse levantamento foi possível alcançar a finalidade do trabalho de averiguar se as funções que as sociedades em conta de participação exercem nos dias atuais são semelhantes às funções que exerciam em sua origem. 
Assim, este trabalho apontou que, por questões tributárias, societárias e contratuais, este tipo societário é muito utilizado atualmente para estruturar negócios imobiliários e projetos florestais. Portanto, a utilização hodierna das sociedades em conta de participação é bastante distinta da função que justificou o seu surgimento.

A partir da análise desenvolvida nesta dissertação, foi possível verificar que, atualmente, a utilização da sociedade em conta de participação está sofrendo um desvirtuamento, já que este tipo societário vem sido utilizado para estruturar operações fraudulentas e para evitar a aplicação de normas mais rígidas.

Não obstante a constatação esposada acima, a sociedade em conta de participação está adequada e ainda é conveniente à economia e ao contexto históricocultural brasileiro, já que constitui um mecanismo apto a estruturar diversos negócios e, portanto, contribui com o desenvolvimento da economia nacional.

Os casos de desvirtuamento não podem servir como desestímulo à utilização e manutenção desse tipo societário. Os casos de desvirtuamento devem ser punidos e, para tanto, o entendimento de todas as vertentes relacionadas às sociedades em conta de participação é tão importante. 


\section{REFERÊNCIAS BIBLIOGRÁFICAS}

ALLEN, Bradley D. The undefined definition of a security: why investments contract is the last security standing and a proposal for the adoption of a contextual analysis to determine its reach. Berkeley, may 2007. Disponível em: <www.works.bepress.com/bradley_allen/1>. Acesso em: 26 jun. 2012.

ALMEIDA, Carlos Guimarães de. A virtuosidade da sociedade em conta de participação. Revista de Direito Mercantil, Industrial, Econômico e Financeiro, n. ${ }^{\circ}$ 08, São Paulo, RT, 1972, p. 56-58.

ALMEIDA, José Gabriel de Assis de. A sociedade em conta de participação. Rio de Janeiro: Forense, 1989.

ALVARES, Jefferson Siqueira de Brito. O atual conceito de valor mobiliário. Revista de Direito Mercantil, Industrial, Econômico e Financeiro, v. 45, n. 142, São Paulo, RT, abr.-jun. 2006.

ARANGIO-RUIZ, Vicenzo. La società in diritto romano. Napoli: Casa Editrice Dott. Eugenio Jovene, 1950.

ARCANGELI, Ageo. La società in accomandita símplice. Turim: Fratelli Bocca, 1903.

ASCARELLI, Tulio. Sociedade em conta de participação e imposto de sêlo. Ensáios e Pareceres. São Paulo: Saraiva, 1952.

Corso di Dirrito Commerciale - Introduzione e Teoria dell'a Impresa. 3. ed. Milão: Giuffrè, 1962. Traduzido por COMPARATO, Fábio Konder. Origem do Direito Comercial. Revista de Direito Mercantil, Industrial, Econômico e Financeiro n. ${ }^{\circ}$ 103. São Paulo: Malheiros, 1996. 
Problemas das sociedades anônimas e direito comparado. 2. ed. São Paulo: Saraiva, 1969.

. Problemas das sociedades anônimas e direito comparado. Campinas: Bookseller, 1999.

Iniciação ao estudo do direito mercantil. São Paulo: Minelli, 2007.

AUBRY, Rau. Cours de Droit Civil Français d'après la méthode de Zachariae. Paris: Marchal \& Billard, 1917.

AZEVEDO, Antonio Junqueira de. Negócio jurídico: existência, validade e eficácia. 4.ed. atual. de acordo com o novo Código Civil (Lei n. 10.406, de 10-1-2002). São Paulo: Saraiva, 2002.

BARRETO FILHO, Oscar. Regime jurídico das sociedades de investimentos. São Paulo: Max Limonad, 1956.

Das sociedades de investimentos (Investment Trusts). São Paulo: Max Limonad, 1956.

Teoria do estabelecimento comercial: fundo de comércio ou fazenda mercantil. 2. ed. São Paulo: Saraiva, 1988.

BASSO, Maristela. Joint venture: manual prático. Porto Alegre: Livraria do Advogado, 1994.

BEVILAQUA, Clóvis. Teoria geral do direito civil. 2 ed. Rio de Janeiro: Editora Rio, 1980.

BIANCHI, Francesco Saverio. Corso di codice civile italiano. v. IX. Torino: Unione Tipografico, 1895.

BORBA, José Edwaldo Tavares. Direito Societário. 11. ed. rev. aum. e atual. Rio de Janeiro: Renovar, 2008. 
BORGES, João Eunápio. Curso de direito comercial terrestre. Rio de Janeiro: Forense, 1967.

BRUNETTI, Antonio. Trattato del diritto delle società: parte generale - società personali. Milano: Giuffrè, 1946.

BULGARELLI, Waldirio. Sociedades, empresa e estabelecimento. São Paulo: Atlas, 1980.

CANDIAN, Aurelio Donato. Lezioni di diritto commerciale. Padova: Cedam, 1928.

CARLI, Filipo. Estoria del commercio italiano: il mercato nell'ed del comune. v. II. Pádua: Cedam, 1936.

CAROSELLI, Oscar. L’associazione in partecipazione. Padova: CEDAM, 1930.

CARVALHOSA, Modesto; EIZIRIK, Nelson. A nova Lei das S/A. São Paulo: Saraiva, 2002.

COMPARATO, Fábio Konder. O direito ao lucro nos contratos sociais. Direito Empresarial - Estudos e Pareceres. São Paulo: Saraiva, 1990.

COSTA, José Maria da. A sociedade em conta de participação no direito de empresa do Código Civil de 2002. (Dissertação de Mestrado). São Paulo: Pontifícia Universidade Católica, Faculdade de Direito, 2006.

CUNHA, Paulo A. V. Do patrimônio - Estudo de direito privado. v. I. Lisboa: Minerva, 1934.

DIAS, Luciana Pires. Regulação e auto-regulação no mercado de valores mobiliários. (Dissertação de Mestrado). São Paulo: Universidade de São Paulo, Faculdade de Direito, 2005.

DIREITO, Carlos Alberto Menezes. Direito positivo aplicado. Rio de Janeiro: Renovar: 2008. 
DONATO, Milena Oliva. Patrimônio separado: herança, massa falida, securitização de créditos imobiliários, incorporação imobiliária, fundos de investimento imobiliário, trust. São Paulo: Renovar, 2009.

DONOSO, Denis; RAMOS, Glauco Gumerato. Sociedade em conta de participação em juízo: análise da sociedade em conta de participação à luz dos pressupostos processuais. Direito processual empresarial (Estudos em Homenagem a Manoel de Queiroz Pereira Calças). São Paulo: Campus Elsevier, 2012.

DUGUIT, Léon. L'autonomie de la volonté. Les transformations générales du droit privé depuis le Code Napoléon. Paris: Librairie Félix Alcan, 1912.

EIZIRIK, Nelson; GALL, Ariádna; PARENTE, Flávia; HENRIQUES, Marcus. Mercado de capitais - regime jurídico. 2. ed. Rio de Janeiro: Renovar, 2008.

; CARVAlhOSA, Modesto. A nova Lei das S/A. São Paulo: Saraiva, 2002.

FERRARA, Francesco. Teoria delle persone giuridiche. Napoli: E. Marghieri, 1923. Trattato di diritto civile italiano. v. 1. Roma: Athenaeum, 1921.

FERREIRA, Renato Luis Bueloni. Ensaio sobre a sociedade unipessoal no direito brasileiro e no direito estrangeiro. (Dissertação de Mestrado). São Paulo: Universidade de São Paulo, Faculdade de Direito, 2001.

FERREIRA, Waldemar. Tratado de sociedades mercantis. 5. ed. São Paulo: Livraria Freitas Bastos S/A, 1958.

FERRI, Giuseppe. Le societá. Torino: Unione Tipografico - Editrice Torinese, 1971.

FERRO-LUZZI, Paolo. I contratti associativi. Milano: Giuffrè, 1971.

FILÓCOMO, André. Empresas e sociedades unipessoais no direito brasileiro. (Dissertação de Mestrado). São Paulo: Universidade de São Paulo, Faculdade de Direito, 2000. 
FRANÇA, Erasmo Valladão Azevedo e Novaes. A sociedade em comum. São Paulo: Malheiros, 2013.

FRANCO, Vera Helena de Mello. As sociedades de pessoas na atualidade. Uma visão comparativa crítica. Revista de Direito Mercantil, Industrial, Econômico e Financeiro, n. ${ }^{\circ}$ 157, p. 93-111, São Paulo, Malheiros, 2011.

FRONTINI, Paulo Salvador. Empresário. Pessoa natural. Seu patrimônio pessoal e a afetação de bens. Direitos e obrigações à atividade econômica. Separação dessas duas massas patrimoniais por força das normas do Código Civil vigente. In: WALD, Arnoldo (Coord.). Doutrinas Essenciais - Direito Empresarial. v. VI (Recuperação judicial e falência). São Paulo: RT, 2011.

GABALDON, Theresa A. A sense of security: an empirical study. The Journal of Corporation Law, v. 25, n. 2, University of Iowa, p. 307-347, winter 2000.

GALGANO, Francesco. Lex mercatoria. 5. ed. Bologna: Il Mulino, 2010. Lex mercatoria (Introdução, Item 1). Traduzido por FRANÇA, Erasmo V. A. N. Temas de Direito Societário, Falimentar e Teoria da Empresa. São Paulo: Malheiros, 2000.

Il contratto di società, le società di persone. 2. ed. Bologna: Zanichelli, 1981.

Le società in genere - le società di persone. Trattato di diritto civile e commercial. Bologna: Giuffrè, 1982.

Associazione non riconosciute - comitati. 2. ed. aggiornata. Bologna: Zanichelli, 1976.

GALIZZI, Gustavo Oliva. A sociedade em conta de participação como subespécie do gênero “joint venture”. Revista de Direito Mercantil, Industrial, Econômico e Financeiro, n. ${ }^{\circ}$ 135, São Paulo, RT, 2004, p. 89-90. 
GALL, Ariádna; PARENTE, Flávia; HENRIQUES, Marcus; EIZIRIK, Nelson. Mercado de capitais - regime jurídico. 2. ed. Rio de Janeiro: Renovar, 2008.

GANDARA, Luis Fernandez de La. La atipicidad em derecho de sociedades. Madrid: Portico, [s.d.].

GARRIGUES, Joaquin. Tratado de derecho mercantil. tomo I. v. I. Madrid: Revista de Derecho Mercantil, 1930.

GHIDINI, Mario. L’associazione in partecipazione. Milano: Giuffré, 1959.

GOLDBERG, Daniel Krepel. A Lei 10.303, de 2001, e a inclusão dos derivativos no rol dos valores mobiliários. Revista de Direito Mercantil, Industrial, Econômico e Financeiro, n. 129, São Paulo, RT, jan.-mar. 2003, p. 73-82.

GOLDSCHIMIT, Levin. Storia universale del diritto commerciale. Tradução de POUCHAIN, Vittorio; SCIOLOJA, Antonio. Milão, Nápole, Palermo e Roma: UTET, 1913.

GOMES, Orlando. Introdução ao direito civil. 12. ed. Rio de Janeiro: Forense, 1997.

GONÇALVES NETO, Alfredo de Assis. Lições de direito societário: regime vigente e inovações do novo Código Civil. São Paulo: Juarez de Oliveira, 2002.

Direito de empresa: comentários aos artigos 966 a 1195 do Código Civil. 2. ed. rev. atual. e ampl. São Paulo: RT, 2008.

GRANDI, Salvatore Giovanni. L'associazione in partecipazione. Milano: Casa Editrice Dottor Francesco Vallardi, 1939.

GUERRA, Pietro. Le società di participazione. Milano: Casa Editrice Dottor Francesco Vallardi, 1957. 
GUERREIRO, José Alexandre Tavares. Sociedade Comercial - Conta de participação - Dissolução - Possibilidade de recurso ao Judiciário. Revista de Direito Mercantil, Industrial, Econômico e Financeiro, n. ${ }^{\circ}$ 54, São Paulo, RT, abr.- jun. 1984, p. 126130.

GUIMARÃES, João Manuel de. O Direito, v. 29, Lisboa, Typographia Lisbonense, 1882, p. 333-340.

RAMOS, Glauco Gumerato; DONOSO, Denis. Sociedade em conta de participação em juízo: análise da sociedade em conta de participação à luz dos pressupostos processuais. Direito processual empresarial (Estudos em Homenagem a Manoel de Queiroz Pereira Calças). São Paulo: Campus Elsevier, 2012.

GUSMÃO, João Manoel Carlos de. Operações em conta de participação assumem o caracter de verdadeira sociedade? quaes os elementos caracteristicos das operações em conta de participação? Theses e Dissertação apresentadas A' Faculdade de Direito de São Paulo para o concurso que deve ter lugar em Junho de 1882. São Paulo: 1882, p. 15-16.

HAMILTON, Robert W. Fundamentals of modern business. Boston: Little Brown. 1989.

HARRIS, Ron. The institutional dynamics of early modern eurasian trade: the commenda and the corporation. Disponível em: <http://ssrn.com/abstract=1294095>. Acesso em: 25 abr. 2012.

HENRIQUES, Marcus; EIZIRIK, Nelson; GALL, Ariádna; PARENTE, Flávia. Mercado de capitais - regime jurídico. 2. ed. Rio de Janeiro: Renovar, 2008.

HESPANHA, António Manuel Botelho. Panorama histórico da cultura jurídica européia. Mem Martins, Portugal: Publicações Europa-América, 1998. 
HILDEBRAND, Lucas Fajardo Nunes. Patrimônio, patrimônio separado ou especial, patrimônio autônomo. In: FRANÇA, Erasmo Valladão Azevedo e Novaes (Coord.). Direito societário contemporâneo I. São Paulo: Quartier Latin, 2009.

LARENZ, Karl. Derecho civil - parte general. Tradução espanhola de IZQUIERDO Y MACIAS-PICAVEA, Miguel. Madri: Editorial Revista de Direito Privado, 1978, p. 405-406.

LATTES, Alessandro. Il diritto commercial nella legislazione statutaria delle città italiane. Milano: Ulrico Hoepli, 1884.

LEÃES, Luis Gastão Paes de Barros. O conceito de "security" no direito norteamericano e o conceito análogo no direito brasileiro. Revista de Direito Mercantil, Industrial, Econômico e Financeiro, v. 14, São Paulo, RT, 1974, p. 41-60.

LOBO, Carlos Augusto da Silveira. Os valores mobiliários. Revista de Direito Mercantil, Industrial, Econômico e Financeiro, v. 10, n. ${ }^{\circ}$ 36, abr.-jun. 2007, 1974.

LOPES, José Reinaldo Lima. Negócio fiduciário, comunhão de interesses e sociedade em conta de participação. Jornal O Estado de São Paulo. Edição de 13 de junho de 1987.

LOPES, Mauro Brandão. Ensaio sôbre a conta de participação no direito brasileiro. São Paulo: RT, 1964.

A sociedade em conta de participação. São Paulo: Saraiva, 1990.

LOSS, Louis; SELIGMAN, Joel. Fundamentals of Securities Regulation. 5. ed. Boston: Little Brown, 2004.

LYNCH, Maria Antonieta. O patrimônio de afetação e as empresas individuais de responsabilidade limitada. Revista de Direito Mercantil, Industrial, Econômico e Financeiro, n. ${ }^{\circ}$ 148, São Paulo, Malheiros, 1996, p. 100-108. 
MARCONDES, Sylvio. Limitação da Responsabilidade de Comerciante Individual. Monografia para o Concurso à Cátedra de Direito Comercial da Faculdade de Direito da Universidade de São Paulo, 1956, p. 234.

Qualificação e classificação das sociedades. Problemas de Direito Mercantil, São Paulo, Max Limonad, 1970, p. 163-181.

. Do objeto de direito: patrimônio. Problemas de Direito Mercantil, São Paulo, Editora Max Limonad, 1970, p. 75-85.

Questões de Direito Mercantil. São Paulo: Saraiva, 1977.

MARGHIERI, Alberto. Società e associazione commerciale. Napóle: Eugenio Marghieri, 1914.

Società e associazione commerciale. Nápole: Eugenio Marghieri, 1921.

MARIZ DE OLIVEIRA, Ricardo. Inexistência de sucessão tributária ao Imposto de Renda do caso de simples aquisição de imóvel comercial, exploração da mesma atividade no local e anterior existência de sociedade em conta de participação com o antigo proprietário. Direito Tributário Atual. (Resenha tributária - v. 6). São Paulo: Instituto Brasileiro de Direito Tributário, 1982.

MARRONE, Matteo. Instituzioni di diritto romano. 8. ed. São Paulo: Saraiva, 1995.

MARTINS, Fran. Curso de Direito Comercial: Empresa comercial, empresários individuais, microempresas, sociedades comerciais, fundo de comércio. 31. ed. Rio de Janeiro: Forense, 2007.

MATTOS FILHO, Ary Oswaldo. O conceito de valor mobiliário. Revista de direito mercantil, industrial, econômico e financeiro, v. 59, São Paulo, RT, jul.-set. 1985, p. $30-55$. 
Cédulas de crédito bancário devem ser reguladas pela CVM. Disponível

em: $<$

http://www.bmfbovespa.com.br/juridico/noticias-e-

entrevistas/Noticias/080424NotA.asp>. Acesso em: 16 jun. 2011.

CCB é valor mobiliário? Revista Capital Aberto, ano 05, n. ${ }^{\circ}$ 56, São Paulo, Editora Capital Aberto, abril/2008, p. 70-71.

MAZEAUD, Henri; MAZEAUD, León; MAZEAUD, Jean. Leçons de Droit Civil. 3. ed. tomo I. Paris: Éditions Montchrestien, 1955.

MAZEAUD, Jean; MAZEAUD, León; MAZEAUD, Henri. Leçons de Droit Civil. 3. ed. tomo I. Paris: Éditions Montchrestien, 1955.

MAZEAUD, León; MAZEAUD, Jean; MAZEAUD, Henri. Leçons de Droit Civil. 3. ed. tomo I. Paris: Éditions Montchrestien, 1955.

MENDES, Octavio. Direito comercial terrestre. São Paulo: Elsevier, 1920.

MENDONÇA, José Xavier Carvalho de. Tratado de direito comercial brasileiro. Rio de Janeiro: Livraria Freitas Bastos S.A., 1959.

Tratado de direito comercial brasileiro. v. I. livro I. Rio de Janeiro: Freitas Bastos, 1963.

MESSINEO, Francesco. Manuale di diritto civile e comerciale. 8. ed. Milano: Giuffrè, 1958.

MIGNONE, Gianni. Un contratto per i mercanti del mediterrâneo. L'evoluzione del rapporto partecipacivo. Napoli: Jovene, 2005.

MONTEIRO, João Pereira. Da sociedade em conta de participação. O Direito, v. 30, Lisboa, Typographia Lisbonense, 1883. 
MOREIRA ALVES, José Carlos. Direito romano. 14. ed. Rio de Janeiro: Forense, 2007.

NORONHA, Fernando. Patrimônios especiais - sem titular, autônomos e coletivos. São Paulo: RT, 1998.

Patrimônios especiais - sem titular, autônomos e coletivos. Revista dos Tribunais n. ${ }^{\circ}$ 747, ano 87, São Paulo, RT, jan. 1998, p. 11-34.

OLIVEIRA, José Lamartine Corrêa de. A dupla crise da personalidade jurídica. São Paulo: Saraiva, 1979.

Conceito de pessoa jurídica. Tese apresentada à Faculdade de Direito da Universidade do Paraná para concurso de livre docência de direito civil. Curitiba, 1962.

PELA, Juliana Krueger. As golden shares no direito brasileiro. São Paulo: Quartier Latin, 2012.

PARENTE, Flávia; HENRIQUES, Marcus; EIZIRIK, Nelson; GALL, Ariádna; Mercado de capitais - regime jurídico. 2. ed. Rio de Janeiro: Renovar, 2008.

PENTEADO, Luciano de Camargo. Princípios em Pontes de Miranda, patrimônio e patrimônios - um legado para o direito privado. In: GORGA, Érica; PELA, Juliana Krueger (Coords.). Estudos avançados de direito empresarial: contratos, direito societário e bancário. São Paulo: Campus, 2012.

PENTEADO JR., Cassio M. C. A afetação do patrimônio especial como exceção ao princípio de sua universalidade - conteúdo jurídico e efeitos. Revista de Direito Bancário, do Mercado de Capitais e da Arbitragem, n. ${ }^{\circ}$ 16, ano 5, São Paulo, RT, abr.- jun. 2002, p. 102-111.

PEREIRA, Caio Mario da Silva. Instituições de direito civil. 19. ed. Rio de Janeiro: Forense, 2001.

PICCHI, Flávio Augusto. A sociedade em conta de participação e os contratos de investimento coletivo: paralelismo e assimetria. Revista de Direito Mercantil, 
Industrial, Econômico e Financeiro, n. ${ }^{\circ}$ 134, São Paulo, RT, abr.-jun./2004, p. 193206.

PONTES DE MIRANDA, Francisco Cavalcanti. Tratado de Direito Privado. 3. ed. tomo XLIX. São Paulo: RT, 1984.

PORTUGAL, Bernardo Lopes. A sociedade em conta de participação no novo Código Civil e seus aspectos tributários. In: RODRIGUES, Frederico Viana (Org.). Direito de Empresa no Novo Código Civil. Rio de Janeiro: Forense, 2004.

QUEIROZ, José Eduardo Carneiro de. Valores mobiliários, oferta pública e oferta privada. Revista de Direito Bancário, do Mercado de Capitais e da Arbitragem, n. ${ }^{\circ}$ 41, São Paulo, RT, jul.-set. 2008, p. 121-126.

RAMIRES, Rogério. A sociedade em conta de participação no direito brasileiro. São Paulo: Almedina, 2011.

REHME, Paul. Historia universal del derecho mercantil. Madrid: Revista de Derecho Privado, 1941.

REQUIÃO, Rubens. A preservação da sociedade comercial pela exclusão do sócio. Tese apresentada para o concurso à cátedra de direito comercial da Faculdade de Direito da Universidade do Paraná. Curitiba, 1959.

ROYER, Copper. Traité des Societés. Paris: Librairie du Recueil Sirey, 1938.

RUGGIERO, Roberto de. Instituições de direito civil. v. 2. São Paulo: Saraiva, 1957.

SALGADO, Paulo Cavalcanti. Das sociedades em conta de participação no direito comercial brasileiro. Recife: Imprensa Industrial, 1913.

SALOMÃO FILHO, Calixto. "Societas" com relevância externa e personalidade jurídica. Revista de Direito Mercantil, Industrial, Econômico e Financeiro, n. ${ }^{\circ}$ 81, São Paulo, RT, 1991, p. 66-78.

Direito concorrencial: as estruturas. São Paulo: Malheiros, 1998. 
O novo direito societário. São Paulo: Malheiros, 2006.

O novo direito societário. 4. ed. rev. ampl. São Paulo: Malheiros, 2011.

SCALZILLI, João Pedro, SPINELLI, Luis Felipe. Reflexões sobre a sociedade em conta de participação no direito brasileiro. Revista Jurídica Empresarial, ano 3, $\mathrm{n}^{\circ}$ 12, Notadez, jan.-fev. 2010, p. 11-105.

SELIGMAN, Joel; LOSS, Louis. Fundamentals of securities regulation. 5. ed. Boston: Little Brown, 2004.

SPADA, Paolo. La tipicità della società. Padova: Cedam, 1974.

SPINELLI, Luis Felipe; SCALZILLI, João Pedro. Reflexões sobre a sociedade em conta de participação no direito brasileiro. Revista Jurídica Empresarial, n. ${ }^{\circ} 12$, ano 3, Notadez, jan.-fev. 2010, p. 11-105.

STURZENEGGER, Luiz Carlos. A doutrina do "patrimônio de afetação" e o novo sistema de pagamentos brasileiro. Revista de Direito Bancário, do Mercado de Capitais e da Arbitragem, n. ${ }^{\circ}$ 11, ano 4, São Paulo, RT, jan.- mar. 2001, p. 229-244.

SZTAJN, Rachel. Contrato de sociedade e formas societárias. São Paulo: Saraiva, 1989.

Sobre a desconsideração da personalidade jurídica. Revista dos Tribunais, ano 88, v. 762, São Paulo, RT, 1988, p. 81-97.

; VERÇOSA, Haroldo Malheiros Duclerc. A incompletude do contrato de sociedade. Revista de Direito Mercantil, Industrial, Econômico e Financeiro, n. ${ }^{\circ}$ 131, São Paulo, Malheiros, 2003, p. 15.

TELES, Inocêncio Galvão. Das universalidades. Lisboa: Minerva, 1940. 
TOLEDO, Paulo Fernando Campos Salles de. Valores Mobiliários - Inteligência do artigo $2^{\circ}$, N. III da Lei 6.385, de 1976. Justitia. São Paulo, RT, jul./set. 1983, p. 176184.

TOMAZETTE, Marlon. Curso de direito empresarial. v. 1. São Paulo: Atlas, 2008.

ULHOA COELHO, Fabio. Manual de direito comercial. 20. ed. São Paulo: Saraiva. 2008.

A falência de empresário titular de patrimônio separado. Direito Processual Empresarial (Estudos em Homenagem a Manoel de Queiroz Pereira Calças). São Paulo: Campus, 2012.

Curso de direito comercial. 5. ed. v. 2. São Paulo: Saraiva, 2002.

VAMPRÉ, Spencer. Tratado elementar de direito comercial. Rio de Janeiro: Imprenta, 1921.

VERÇOSA, Haroldo Malheiros Duclerc. A CVM e os contratos de investimento coletivo ("boi gordo" e outros). Revista de Direito Mercantil, Industrial, Econômico e Financeiro, n. ${ }^{\circ}$ 108, São Paulo, RT, out.-dez. 1997, p. 91-100.

VIVANTE, Cesare. Trattato di diritto commerciale. (Le società commerciali). v. II Milano: Casa Editrice Dottor Francesco Vallardi, 1923.

WALD, Arnoldo. In: TEIXEIRA, Sálvio de Figueiredo (Coord.). Comentários ao novo Código Civil. Do direito da empresa. Livro 2. v. 14. Rio de Janeiro: Forense, 2005.

WARDE JÚNIOR, Walfrido Jorge. Responsabilidade dos sócios: a crise da limitação da responsabilidade e a teoria da desconsideração da personalidade jurídica. Belo Horizonte: Del Rey, 2007. 
WEBER, Max. The History of Commercial Partnerships in the Middle Ages.

Traduzido e introduzido por Lutz Kaelber. Oxford: Rowman \& Littlefield Publishers Inc., 2003.

WIEACKER, Franz. Hausgenossenschaft und Erwerbgesellchaft, Untersuchungen zur Geschichte de Roemischen Gesellschaftsrechts. Societas. Weimar,1936.

YAZBEK, Otavio. Regulação do mercado financeiro e de capitais. Rio de Janeiro: Elsevier, 2007.

ZANELLATO, Marco Antonio. Uma nova prática abusiva no mercado de consumo.

Disponível em: <www.mp.gov.br/portal/page/.../Artigo-SocContadePaticipação.doc>. Acesso em: 29 jun. 2012. 